UNIVERSIDADE DE SÃO PAULO

FACULDADE DE FILOSOFIA, LETRAS E CIÊNCIAS HUMANAS DEPARTAMENTO DE GEOGRAFIA

PROGRAMA DE PÓS-GRADUAÇÃO EM GEOGRAFIA HUMANA

GUSTAVO FRANCISCO TEIXEIRA PRIETO

\title{
A sede do capital: \\ o abastecimento de água em favelas da periferia da cidade do Rio de Janeiro
}

Versão Revisada 
UNIVERSIDADE DE SÃO PAULO

FACULDADE DE FILOSOFIA, LETRAS E CIÊNCIAS HUMANAS

DEPARTAMENTO DE GEOGRAFIA

PROGRAMA DE PÓS-GRADUAÇÃO EM GEOGRAFIA HUMANA

A sede do capital:

o abastecimento de água em favelas da periferia da cidade do Rio de Janeiro
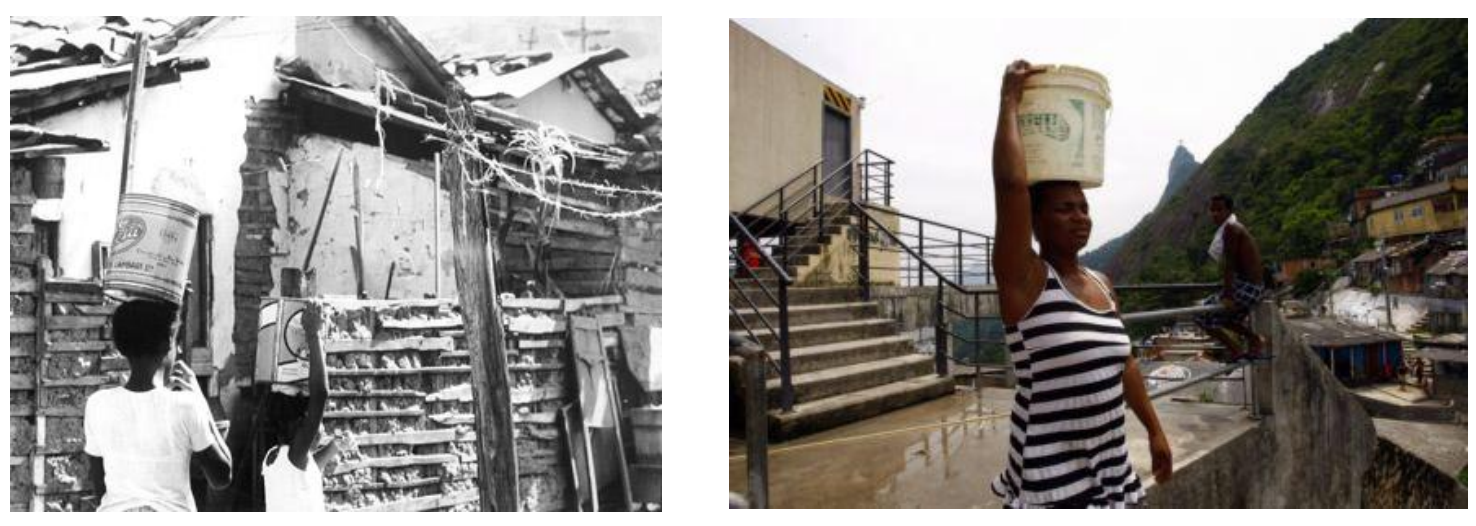

Dissertação apresentada ao Departamento de Geografia da Faculdade de Filosofia, Letras e Ciências Humanas da Universidade de São Paulo para obtenção do título de Mestre em Geografia Humana.

Área de concentração: Geografia Humana

Orientadora: Prof ${ }^{\mathrm{a}}$. Dr ${ }^{\mathrm{a}}$. Vanderli Custódio

\section{Versão Revisada}

De acordo: 
PRIETO, Gustavo Francisco Teixeira.

A sede do capital: o abastecimento de água em favelas da periferia da cidade do Rio de Janeiro

Dissertação apresentada ao Departamento de Geografia da Faculdade de Filosofia, Letras e Ciências Humanas da Universidade de São Paulo para obtenção do título de Mestre em Geografia Humana.

Aprovado em:

Banca Examinadora

Prof. Dr. Instituição:

Julgamento: Assinatura:

Prof. Dr. Instituição:

Julgamento: Assinatura:

Prof. Dr. Instituição:

Julgamento: Assinatura: 
Para as moradoras e moradores das periferias das metrópoles que convivem cotidianamente com o abastecimento de água negado.

Para Delucinda, minha mãe, que me ensinou que quando a abstração do pagamento da água não se realiza, o concreto é a perversidade dos baldes e latas d'água na cabeça. E que isso é a expressão de uma crise e uma questão de classe.

Para Elisa, meu amor, uma sede que nunca sacia. 


\section{AGRADECIMENTOS}

À Delucinda, minha mãe, e Flavio, meu pai, que me propiciaram uma educação libertária e carinhosa, me estimulando a leitura, a escrita (quantas poesias declamamos e quantos pequenos saraus fizemos juntos) e as descobertas profundas e singelas. Agradeço com todo amor o prazer de ter conhecido com vocês Vinícius de Moraes, Clara Nunes, Luiz Gonzaga, Dolores Duran, Hermeto Pascal, Dona Ivone Lara, Macunaíma, Capitu, Dona Benta, Ana Terra, o balé no Municipal, o futebol no Maracanã, o funk na favela, o samba na laje. Obrigado por me ensinarem a importância da crítica e das lutas sociais e por me mostrarem suas fragilidades e nossa vida de proletários pobres como uma utopia, um vir-aser, o devir de muitos sonhos, com muita lágrima, mas com risadas e cervejas.

Para minhas irmãs maravilhosas. Bárbara, aprendo muito com sua firmeza e delicadeza. Você é preciosa! E Andréa, emotiva e vibrante, que me ensina muito com sua intensidade. Abraço fraterno ao meu cunhado Amauri e um beijo no meu sobrinho querido Gianlucca.

Para Anita, minha avó, sua ausência é repleta de lembranças de sua postura alegre e crítica de viver. Agora relembro suas palavras: "Saudade sim, tristeza não!”.

Agradeço aos moradores das favelas e periferias que partilharam um momento de suas vidas comigo, especialmente agradeço à "Esther" e "Maria" e suas famílias. Muito obrigado!

Ao Conselho Nacional de Desenvolvimento Científico e Tecnológico (CNPq), pelo financiamento da pesquisa.

Agradeço a todos os professores das escolas públicas que (sempre) frequentei. É com muito orgulho e com muita honra em que hoje, também professor, percebo ainda mais intensamente seu trabalho belo e difícil, e a militância necessária para a educação pública, gratuita e de qualidade. Aos mestres em particular Ruy Moreira, Ariovaldo Umbelino de Oliveira, Maria Lucia Oliveira Sonia Ferraz e Marisol Barenco. À Odette Seabra e Elizete Menegat que compuseram minha banca de qualificação com uma generosidade ímpar, à Amélia Damiani e Cibele Rizek com contribuições indeléveis na arguição dessa dissertação, um momento de aprendizado fenomenal (muito obrigado!) e à Satie Mizubuti, querida tutora do PET-Geografia-UFF pelo enorme aprendizado nas deliciosas tardes de Niterói. É com imenso carinho que lhes agradeço.

Agradeço aos professores companheiros e educando-educadores do Cursinho PréUniversitário PSICO-USP, espaço de formação e educação popular. 
Obrigado a Vanderli, orientadora desse trabalho, sempre aberta ao diálogo e as conversas propositivas, acompanhando serenamente meu trajeto inquieto com críticas e sugestões que muito me ajudaram.

O trabalho intelectual é deveras solitário, repleto de angústias e inquietações, porém sempre é acompanhado de parcerias, amizades e companheirismo. Aprendi muito com os amigos nas casas provisórias, permanentes, transitórias, enfim, nos lugares em que habitei, pois "habitar é deixar rastros". Agradeço as conversas no bosque do Colégio Técnico da Universidade Federal Rural do Rio de Janeiro em Seropédica, ainda no Ensino Médio, com Thiago, Carol Porto, Raquel e Daiana, especialmente. Nas repúblicas de Niterói, nos momentos incríveis que passei na Universidade Federal Fluminense com Wanderson, Leonardo e Bruno (amigos que conviveram com minha hiperatividade e com meu jeito bagunceiro durante quase quatro anos, e que foram irmãos, primos, pais, enfim tudo. Convivemos na "dor e a delícia de ser o que é".).

Já em São Paulo, a casa do Paulão e da Carol, amigos lindos que me mostraram o amor, o carinho e a dedicação nessa Paulicéia que hoje amo tanto. No CRUSP habitei o "cortiço" do Pedrinho, queridíssimo, que abriu sua casa e seu coração, um parceiro de várias aventuras. Sempre presente nos sambas e pagodes de mesa, o amigo querido Rafael (Xavier), um grande abraço. Atualmente, me encontro no delicioso 107 no Bloco C com a famosa frase na porta "Fora PM da USP, Fora PM do mundo, Amor Livre, Universidade Livre", onde morei com Renata Silveira (minha grande amiga gaúcha parceira de todas as lutas em Sampa) e Jackeline Severina (amiga sambista que me ensinou o respeito e a tolerância). Queridas, passei momentos especiais na companhia maravilhosa de vocês! Atualmente, estão no cantinho cruspiano Joãozão, grande de altura e de coração, e Angélica, simplesmente guerreira. Um beijo grande também nas vizinhas cruspianas Ana Paula (agora mais uma moradora do cafofo da Revolução que é o 107-C), marxista carinhosa nas revisões e debates, agradeço de coração, e à Lígia, politizada e companhia muito agradável.

Agradeço aos amigos petianos por toda aprendizagem. Sinto muito amor por vocês, nossas amizades são profundas e duradouras: Cristiane (irmã, amiga para todas as horas e mãe do lindo Francisco), Paulo Henrique - Joselito (irmão carinhoso e generoso), Camilla (o amor em pessoa, batalhadora, divertida e com uma risada gostosa e inconfundível), Lidice, Ivia (amiga decidida e parceira para os lugares com ou sem clima) e Thabinha (sua delicadeza e sensibilidade são lindas). 
Aos amigos construídos pelo Brasil afora, nos encontros de estudantes de Geografia ou ENGs: Diogo (do Paraná, das tribos do Amazonas, do mundo - abraço fraterno), Theo e Lara (de Porto Alegre), Paulinho (de Minas Gerais) e tantos outros.

Aos amigos do Rio que dialeticamente foi quando vim para São Paulo que nossa relação de carinho aumentou e só aumenta: Mendel e Danee.

São Paulo me trouxe ainda os queridos: Junior (divertido e tranquilo), Renata Sampaio (intensa e inteligente), André Baldraia (dedicado e atencioso), Lucas (amigo historiador que se encantou pelo Rio de Janeiro e suas maravilhas), Carol Mendes (querida e doce amiga), Fê Pinheiro, Anaclara e Marcela, os meninos da Floresta (Marciano, Guto, Tico, Bonito e companhia), Caião, Anuar - Gigante e tantos outros companheiros de trajetória.

Aos queridos parceiros da AGB e do grupo de estudos d'O capital: Léa (amiga querida e muito especial, nossas conversas são fundamentais para mim), Natalia (uma grande e nova amiga), Ju Bruce (uma grande descoberta) e Eduardo - Tarzan (um grande cara).

Um beijo para meus sogros Maria do Carmo e Luis Cesar.

Finalmente, para o amor da minha vida, Elisa. Minha companheira e amiga, que me ajuda e me auxilia na vida cotidiana, com quem aprendo, partilho e divido minhas experiências, vivências e todo o meu amor. Pois, "amor é sede depois de se ter bem bebido". 
O estímulo superficial, o exótico e o pitoresco só têm efeito sobre o estrangeiro. Para retratar uma cidade, o nativo tem que ver outros motivos, mais profundos - motivos de alguém que viaja para o passado em vez de na distância. O livro de um nativo sobre sua cidade será sempre relacionado às suas memórias; o escritor não passou sua infância lá em vão.

Walter Benjamin

A injustiça vem do asfalto pra favela

Há discriminação à vera

Chegam em cartão postal

Em outdoor a burguesia nos revela Que o pobre da favela tem instinto marginal E o meu povo quando desce pro trabalho Pede a Deus que o proteja Dessa gente ilegal, doutor Que nos maltrata e que finge não saber Que a guerra na favela é um problema social (Trecho do Rap da Igualdade, funk carioca, MC Dolores) 


\section{RESUMO}

PRIETO, G. F. T. A sede do capital: o abastecimento de água em favelas da periferia da cidade do Rio de Janeiro. 2011. 257f. Dissertação (Mestrado) - Faculdade de Filosofia, Letras e Ciências Humanas, Universidade de São Paulo, São Paulo, 2011.

Esta pesquisa de Geografia Urbana objetiva analisar o abastecimento de água nas favelas da periferia da cidade do Rio de Janeiro no período da mundialização financeira do capital, principalmente no que se refere aos impactos da implantação de políticas públicas de saneamento, especialmente o Programa Favela Bairro, momento da realização da urbanização de favelas como negócio e do urbano como mercadoria. Compreendemos que viver sem água modifica substancialmente a vida cotidiana e demonstra a crise estrutural do capital. Em outras palavras, entendemos que a nova qualidade do capital contemporâneo é a destruição destrutiva, realizada pela lógica da valorização e da reprodução ampliada, a qual explicita a situação permanentemente crítica da sociedade. Para isso, desdobramos como a crise ecológica se apresenta como crise da água, sendo essa uma das aparências da crise do capital. Expomos nossa compreensão sobre os meandros da crise capitalista e verificamos como a gestão capitalista da água se apresenta em inúmeras metáforas e fetiches, particularmente ancorada no debate sobre a produção de novas raridades e de como os movimentos de transformação da água em mercadoria-água (o mercado de água potável) fundamentam um negócio e um comércio bastante lucrativos. A questão da precariedade do abastecimento de água em favelas na periferia carioca se apresentou como portadora das contradições desse processo. Assim, buscamos compreender como a produção do espaço urbano da Zona Oeste do Rio de Janeiro se realizou, especialmente os movimentos de transformação da urbanização de favelas e de loteamentos na periferia, e como estes se encontram nesse momento de dominância financeira do capital. Observamos então as ilusões da transparência e a ilusão da opacidade desse processo em que o aparelho do Estado, conceitos produzidos por parte da Academia e os meios de comunicação de massa reforçam esses fundamentos baseados no planejamento submetido à mercadoria. Esses processos substanciam a compreensão da situação permanentemente crítica em que se insere marginalmente o proletariado urbano das favelas e periferias da metrópole capitalista. O aparelho do Estado e as políticas públicas paliativas não universalizam e muito menos resolvem as inúmeras problemáticas que envolvem o saneamento. Essa dissertação busca, então, contribuir para a análise crítica da crise capitalista, apontar alguns porquês da sede do capital e contribuir com o debate marxista, especialmente na Geografia.

Palavras-chave: abastecimento de água, crise, Rio de Janeiro, favela, marxismo. 


\begin{abstract}
PRIETO, G. F. T. The thirst of the capital: the water supply in the slum peripheries of the city of Rio de Janeiro. 2011. 257f. Dissertação (Mestrado) - Faculdade de Filosofia, Letras e Ciências Humanas, Universidade de São Paulo, São Paulo, 2011.

This research in Urban Geography aims to analyze the water supply in the slum peripheries of the city of Rio de Janeiro during the financial globalization of capital, especially with regard to the impacts of the implementation of public policies on sanitation, especially the Favela Bairro moment of the slum upgrading and urban as a business as merchandise. We understand that living without water substantially changes the everyday life and demonstrates the structural crisis of capital. In other words, we understand that the new quality of contemporary capital destruction is destructive, performed by the logic of value and expanded reproduction, which explains the situation constantly critical of society. To do this, unfold as the ecological crisis is presented as the water crisis, which is one of the appearances of the crisis of capital. We present our understanding of the intricacies of capitalist crisis and looked at how the capitalist management of water is present in numerous metaphors and fetishes, particularly anchored in the debate on the production of new rarities and how movements of transformation of water into merchandise-water (the drinking water market) an underlying business and a very profitable trade. The issue of precarious water supply in slums on the periphery of Rio de Janeiro introduced himself as the bearer of the contradictions of this process. Thus, we seek to understand how the production of urban space of the West Zone of Rio de Janeiro took place, especially the movements of transformation of slum settlements and in the periphery, and how they are this time of financial dominance of capital. We observed the illusions of transparency and the illusion of opacity of the process in which the state apparatus, concepts produced by the Academy and the media reinforce this plea submitted to the merchandise planning. These processes permanently substantiate the critical situation in which it operates marginally the urban proletariat from the slums and peripheries of capitalist metropolis. The state apparatus and public policies do not universalize palliative let alone solve the numerous problems involving sanitation. This paper seeks, then, to contribute to the critical analysis of capitalist crisis, pointing out some of the whys of the capital and seat contribute to the Marxist debate, especially in geography.
\end{abstract}

Key words: water supply, crisis, Rio de Janeiro, slum, marxism 


\section{LISTA DE MAPAS}

Mapa 1: Áreas de planejamento e regiões administrativas - 2004 56

Mapa 2: Representação cartográfica do zoneamento simbólico da cidade do Rio de Janeiro 66

Mapa 3: Taxa de crescimento percentual por distritos da Região Metropolitana do Rio de Janeiro - 1991/2000 74

Mapa 4: Obras de intervenções em saneamento na Proposta de Revisão do Plano Diretor (2009) .92

Mapa 5: Mapa de intervenções do Programa Favela-Bairro 119

\section{LISTA DE IMAGENS}

Imagem 1: Abastecimento de água negado cotidianamente .................................................35

Imagem 2: Abastecimento de água negado cotidianamente ...............................................35

Imagem 3: O ciclo da água sem a imbricação dialética sociedade-natureza ..........................36

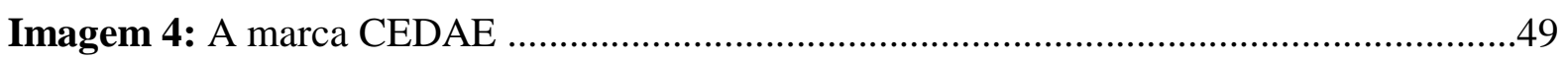

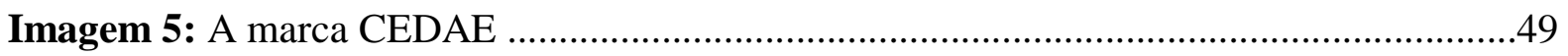

Imagem 6: Esquema de uma economia política do abastecimento de água: da produção ao

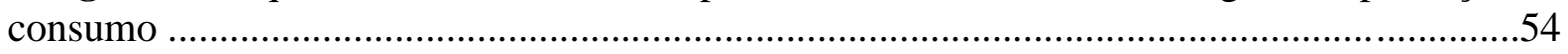

Imagem 7: 11 favelas na periferia carioca (croqui) ......................................................120

\section{LISTA DE TABELAS}

Tabela 1: Matematicamente perto da universalização, distante da equidade no abastecimento de água .55

Tabela 2: Área ocupada pelas favelas segundo as Áreas de Planejamento (AP) e o total do município do Rio de Janeiro .72

Tabela 3: Implementação dos serviços de infra-estrutura em favelas urbanizadas pelo Programa Favela-Bairro ( $1^{\text {a }}$ etapa) em 2000 119 


\section{LISTA DE ABREVIATURAS E SIGLAS}

ADA Amigo dos Amigos

ADIN Ações Diretas de Inconstitucionalidade

ALERJ Assembléia Legislativa do Estado do Rio de Janeiro ANA Agência Nacional de Águas

ANEEL Agência Nacional de Energia Elétrica

AP Áreas de Planejamento

APA Área de Proteção Ambiental

APAFUNK Associação de Profissionais e Amigos do Funk

APD-Rio Apoio às Populações Desfavorecidas da Região Metropolitana do Rio de Janeiro

ASEAC Associação de Empregados de Nível Universitário da CEDAE

ASICA-SUR Asociación de Sistemas Comunitarios de Agua del Sur

BID Banco Interamericano de Desenvolvimento

BNDES Banco Nacional de Desenvolvimento Econômico e Social

BNH Banco Nacional da Habitação

BOT construção-exploração-transferência (sigla em inglês para built, operate, transfer).

CEDAE Companhia Estadual de Águas e Esgotos

CEDAG Companhia Estadual de Águas da Guanabara

CEDAPS Centro de Promoção da Saúde

CEF Caixa Econômica Federal

CEHAB Companhia Estadual de Habitação do Rio de Janeiro

CEMIG Companhia Energética de Minas Gerais

CESB Companhias Estaduais de Saneamento Básico

CHP Centro de Habitação Provisória

CIEDS Centro Integrado de Estudo e Programas de Desenvolvimento Sustentável

CIEP Centro Integrado de Educação Pública

COHAB Companhia de Habitação Popular

CONAMA Conselho Nacional do Meio Ambiente

CPI Comissão Parlamentar de Inquérito

CV Comando Vermelho

CVM Comissão de Valores Mobiliários

ESAG Companhia de Esgotos da Guanabara

ETA Estações de Tratamento de Água 
FAFEG Federação de Favelas da Guanabara

FAFERJ Federação de Favelas do Rio de Janeiro

FFLCH Faculdade de Filosofia, Letras e Ciências Humanas

FGTS Fundo de Garantia por Tempo de Serviço

FGV Fundação Getúlio Vargas

FMI Fundo Monetário Internacional

GEAP Grupo Executivo de Assentamentos Populares

GWP Parceria Global da Água (sigla em inglês para Global Water Partnership)

IAB Instituto de Arquitetos do Brasil

IAE Inspetoria de Águas e Esgotos

IBGE Instituto Brasileiro de Geografia e Estatística

IBAM Instituto Brasileiro de Administração Municipal

IPLANRIO Empresa Municipal de Informática da Prefeitura da Cidade do Rio de Janeiro

IPO Contrato de Assessoramento ao Processo de Reestruturação para a Distribuição Pública de Ações (sigla em inglês para Initial Public Offer)

IPP Instituto Pereira Passos

IVP Iniciativa de Vila Paciência

LIIBRA Liga Internacional de Basquete de Rua

MAB Movimento de Atingidos por Barragens

MTST Movimento dos Trabalhadores Sem-Teto

ONG Organização Não Governamental

ONU Organização das Nações Unidas

PAC Programa de Aceleração do Crescimento

PDT Partido Democrático Trabalhista

PEAD Polietileno de Alta Densidade

PECRJ Plano Estratégico da Cidade do Rio de Janeiro

PED Programa Estadual de Desestatização

PET Programa de Educação Tutorial

PFL Partido da Frente Liberal

PKK Partido dos Trabalhadores do Curdistão

PLANASA Plano Nacional de Saneamento

PNAD Pesquisa Nacional por Amostra de Domicílios

PNRH Plano Nacional de Recursos Hídricos

PNSB Pesquisa Nacional de Saneamento Básico 
PNUD Programa das Nações Unidas para o Desenvolvimento

PPP Parcerias público-privadas

PPS Partido Popular Socialista

PROAP Programa de Urbanização de Assentamentos Populares do Rio de Janeiro

PROFACE Programa de Favelas da Companhia Estadual de Água e Esgotos

PSDB Partido da Social Democracia Brasileira

PSP Participação do setor privado

PT Partido dos Trabalhadores

PTB Partido Trabalhista Brasileiro

RA Região Administrativa

RMRJ Região Metropolitana do Rio de Janeiro

SABESP Companhia de Saneamento Básico do Estado de São Paulo

SANERJ Companhia de Saneamento do Estado do Rio de Janeiro

SDC Superintendência de Desenvolvimento Comunitário

SMDS Secretaria Municipal de Desenvolvimento Social

SMH Secretaria Municipal de Habitação

SMU Secretaria Municipal de Urbanismo da Prefeitura da Cidade do Rio de Janeiro

STF Supremo Tribunal Federal

SURSAN Superintendência de Urbanização e Saneamento

TCE Tribunal de Contas do Estado

TCP Terceiro Comando Puro

UFF Universidade Federal Fluminense

USP Universidade de São Paulo

UIS Unidade de Integração Social

UPP Unidades de Políticas Pacificadoras

WWC Conselho Mundial da Água (sigla em inglês para World Water Council) 


\section{SUMÁRIO}

Introdução 17

1. Da crise das águas às águas da crise na periferia da metrópole capitalista. 26

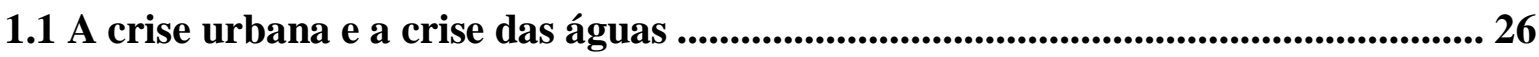

1.2 A produção da raridade ou a produção discursiva da escassez ........................... 33

1.3 Processos de privatização .................................................................................................... 41

1.3.1. A tentativa de privatização strictu sensu da CEDAE........................................... 43

1.4. Acesso à água sob a égide do mercado......................................................................... 47

1.5. Universalização no acesso à água não significa equidade no abastecimento ........ 51

1.6. As águas da crise ........................................................................................................ 57

2. A Ilusão da Transparência e a Ilusão da Opacidade na interpretação da questão social do abastecimento de água................................................................................................... 63

2.1 A ilusão da transparência da Zona Oeste da cidade do Rio de Janeiro ................. 64

2.1.1. A ilusão da transparência na urbanização de favelas e no Programa Favela-Bairro

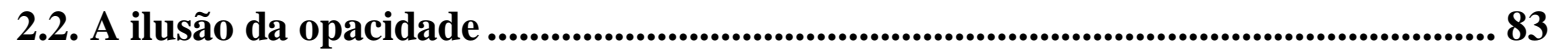

2.2.1. Opacidade do aparelho do Estado: o caso do IBGE .......................................... 83

2.2.2. Opacidade do aparelho de Estado: o caso da CEDAE ........................................ 86

2.2.3. Opacidade do aparelho de Estado: o caso do Plano Diretor e do Planejamento

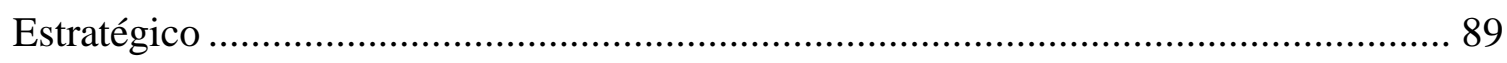

2.2.4. Opacidade teórica: cidade partida, urbanização desordenada e a "renovação" (do

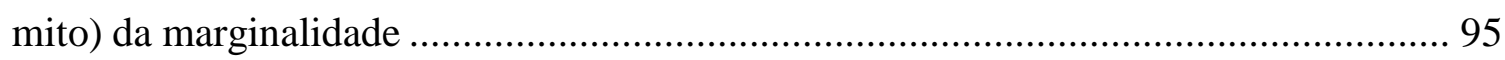

2.2.5. A opacidade da interpretação da mídia.......................................................... 100

3. A urbanização da sociedade e a mundialização do capital: processos e situações para compreender as favelas da periferia da cidade do Rio de Janeiro e o abastecimento de

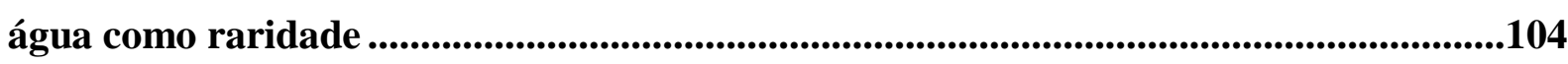

3.1. Redes de infra-estrutura de abastecimento de água ...........................................107

3.2. Políticas públicas e o Programa Favela-Bairro.......................................................112

3.3. A urbanização (crítica) da sociedade: trabalhos de campo em favelas da periferia

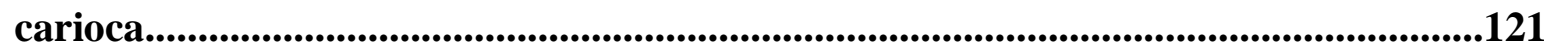

3.3.1. Três Pontes: uma favela na periferia carioca (única da Zona Oeste entre os primeiros selecionados no Programa Favela Bairro 1) 
3.3.2. Paraguai: só quem mora sabe onde é. 128

3.3.3. Favela do Aço: a "renovação" do arquétipo da favela .......................................129

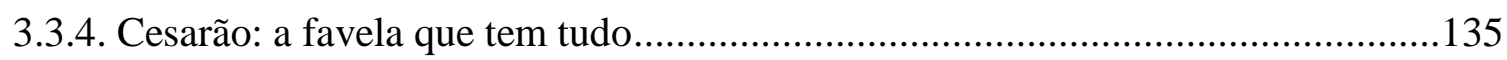

3.3.5. Cesarinho: da casa para o barraco, do tráfico para a milícia................................138

3.3.6. Antares: de habitação provisória à cotidianidade da ausência de infra-estrutura 139

3.3.7. Urucânia: a milícia e a coerção violenta e econômica

3.3.8. Favelas do Rollas 1 e 2: a passagem contraditória do campo para cidade. Uma "grande favela" no Programa Favela Bairro 2 ...............................................................144

3.3.9. Divinéia: uma urbanização de favelas (Favela Bairro 1) após o convênio com o BID - tecendo comparações

3.3.10. Nova Jersey: "novas" perspectivas de urbanização de favelas ou quando uma política pública morre (Rio Comunidade, a ilusão do Favela Bairro 3 e o Programa Morar Carioca).

3.4. A dimensão violenta e a coerção no espaço urbano: o pesquisador se depara com um novo momento da barbárie capitalista.

3.5. Aberturas e fissuras

4. A mercadoria-água e seus segredos .........................................................................155

4.1. O fetichismo da mercadoria-água .......................................................156

4.2. O fetiche do Estado e do princípio poluidor(usuário)-pagador ...........................161

4.3. O fetiche do serviço ambiental (e seu mercado "ambiental") ...............................169

4.4. O fetiche do desenvolvimento sustentável e do bem comum ................................173

4.5. O cativeiro da terra e o cativeiro da água .............................................................177

4.6. Conclusão ou a reafirmação das três classes capitalistas pelo Estado...................187

5. Considerações finais - ou como o capitalismo se travestiu de verde e a sede de reprodução do capital voltou-se para a questão das águas ............................................189

Referências Bibliográficas..............................................................................................195

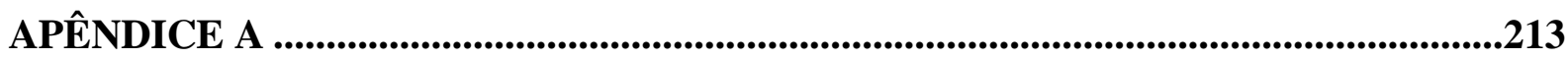

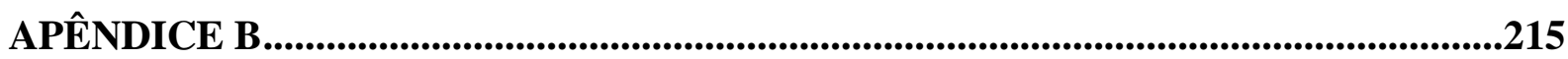




\section{Introdução}

Às vezes você tem que escolher, ou você faz uma comida, ou você toma um banho, pois nem todo dia eles "abrem" a água... Fica difícil, muito difícil viver... É muito difícil viver sem água! (Esther ${ }^{1}$, moradora de favela na periferia carioca).

Essa pesquisa expõe um fragmento das minhas experiências, vivências e memórias como morador da periferia do Rio de Janeiro e do cotidiano de incertezas quanto à irregularidade, à ausência, o racionamento e a ineficiência do sistema de abastecimento de água. Essa experiência foi um dos estopins para iniciarmos em germe a presente dissertação. Além disso, as discussões durante os anos de 2005 a 2008 no âmbito do Programa de Educação Tutorial (PET-Geografia) na Universidade Federal Fluminense foram muito estimulantes para transformar o que era uma inquietação em um projeto de mestrado. A vinda para São Paulo, e particularmente para a Faculdade de Filosofia, Letras e Ciências Humanas, me atravessou completamente e redesenhou os meus caminhos teóricos e práticos. Nessa trajetória, inúmeras foram as contribuições e diálogos travados que resultaram nesse trabalho. Contudo, a metrópole e os encontros propiciados transbordam os limites dessa explanação, e são, como agora, difíceis de serem contemplados apenas em letras miúdas.

Este trabalho já teve várias linhas de discussão em que me embrenhei para tentar não cair nas armadilhas da pauta estabelecida pelo capitalismo - agora travestido de verde - e seu pensamento que se quer único. Dois momentos, porém, considero que foram pontos de inflexão dos debates: o primeiro foi minha aproximação mais intensa e absolutamente estimulante com a obra de Karl Marx, e o segundo foi quando comecei a realizar os trabalhos de campo nas favelas da periferia carioca.

Essas inquietações se encontram nessa pesquisa, que tem como objetivo analisar o abastecimento de água nas favelas da periferia da cidade do Rio de Janeiro no período da mundialização financeira do capital, principalmente no que se refere aos impactos da implantação de políticas públicas de saneamento, especialmente o Programa Favela Bairro, momento da realização da urbanização de favelas como negócio e do urbano como mercadoria.

O processo de pesquisa nos revelou que, diferente do que se propaga, a questão do abastecimento de água está longe de ser resolvida e a universalização dessas infra-estruturas e serviços só existe nos discursos oficiais e burocráticos.

\footnotetext{
${ }^{1}$ Para preservar e resguardar os sujeitos sociais que contribuíram para a pesquisa modificamos seus nomes.
} 
Nesse sentido, compreendemos que viver sem água modifica substancialmente a vida cotidiana e demonstra em nosso entendimento os meandros da crise estrutural em que estamos imersos, conforme desenvolvido por István Mészáros (2005; 2009). Em outras palavras, dizemos que a nova qualidade do capital contemporâneo é a destruição destrutiva, realizada pela lógica da valorização e da reprodução ampliada, a qual explicita a situação permanentemente crítica do conjunto da vida social: desemprego estrutural, precarização do trabalho e destruição da natureza. Natureza essa apropriada privadamente.

A natureza sofre uma pilhagem de suas riquezas naturais e é levada ao limite da exaustão (as crises ecológicas são a aparência desse processo), e os trabalhadores são potencialmente levados aos limites da exploração. Todavia, os limites não são estabelecidos pela natureza, nem pelos trabalhadores explorados no processo produtivo: é o capital que impõe os limites da exploração e das pilhagens, tendo como objetivo a reprodução ampliada de si mesmo, em expansão permanente.

Assim, de uma perspectiva marxista, as crises do modo de produção capitalista constituem expressões inevitáveis de contradições básicas ao funcionamento objetivo desse modo de produção. A crise é a expressão do resultado do desenvolvimento das contradições inerentes ao modo de produção capitalista, pois é na crise que ocorre o momento de explicitação dos contrários. A crise é a negatividade do capital, que se apresenta, em aparência e em essência, como possibilidade de superação do modo de produção ou oportunidade para mais monopolização, sobrelucro para os capitalistas. A unidade entre produção e circulação, na aparência opostos, só é reafirmada através da crise, e é nesse momento que os fios tênues que os ligam mostram-se como verdadeiras amarras. O capital, no movimento de crise cada vez mais permanente, busca "atenuar" sua desmedida. As contradições, porém, são ainda mais aprofundadas. Mediando essas tensões encontra-se o aparelho de Estado que está atentamente funcionando para salvaguardá-lo.

Ao mesmo tempo em que rompe a unidade, a crise corresponde justamente a um ajuste entre os polos em contradição (CARCANHOLO, 1996), socializando as perdas e prejuízos e se apropriando privadamente dos benefícios econômicos e financeiros, primordialmente sob o auspício do Estado e sua transferência de renda. Esse ajuste econômico e social promove ajustes espaciais (HARVEY, 2005), sendo especialmente avassalador para as classes sociais nas quais os capitalistas necessitam realizar "novos" processos de acumulação e produção de capital. 
O capital não cessa de acumular capital numa desmedida que se expressa, dentre outras aparências, na crise ecológica e na crise do abastecimento, fornecimento e domínio privado das águas.

Mészáros (2002) enfatizou o caráter de uma crise estrutural, demonstração da impotência atual do capital de acomodar as forças sociais que desperta e de frear a destruição social e da natureza a que a expansão das relações capitalistas conduz.

Nesse processo, o urbano que engendrou o imaginário de emancipação humana representa, na crise urbana que estamos inseridos, a mais significativa inflexão entre homem e natureza e a sua impossibilidade para todos (DAMIANI, 2009; 2010). Tal ideal de emancipação humana consubstanciado no urbano, que contém dentre outros atributos a separação do homem da natureza e a mudança de qualidade nessas relações, não pode desconsiderar que quanto mais a sociedade se urbaniza, mais se impera extrair da natureza. Porém, o processo exploratório do modo de produção capitalista dá cada vez mais sintomas de que não pode resolver essas questões. Propomos, então, uma análise que exponha a crise das águas como momento que demonstra a produção da água como raridade e a situação permanentemente crítica que se encontra o capitalismo, para assim substanciar as águas da crise estrutural capitalista, de destruição destrutiva e de urbanização crítica.

Compreendemos então o urbano (a sociedade urbana) como totalidade, produto de um processo de produção num determinado tempo histórico. Esse processo é uma realidade que se generaliza, numa escala da cidade à metrópole, e como virtualidade se espraia para a sociedade inteira (LEFEBVRE, 2008). A cidade representa trabalho materializado, produto da divisão técnica e social, materialização da história dos homens, da realização da vida cotidiana, das fissuras do acontecer e forma de apropriação do espaço urbano produzido. A cidade não é mero suporte de processos sociais e econômicos, mas parte decisiva da produção e reprodução do capital (CARLOS, 2003). Já a urbanização, definida por Amélia Damiani (2003, 2008, 2009, 2010) como crítica, tem como fundamento subjetivo negado a massa proletária das periferias metropolitanas, sujeita aos avanços do capital financeiro imobiliário, sob incentivo estatista. Inclui ainda a produção de representação da realidade turva entre a crise social e a crise ambiental, a partir de políticas de "sustentabilidade", como imagética e ilusória de equilíbrio (DAMIANI, 2009).

No que tange a tal discussão, compreendemos que o abastecimento de água se encontra nessa órbita de debates, imerso em camadas espessas de fetiches, como desenvolvimento sustentável, educação ambiental, consumo responsável, preservação, isto é, a naturalização da natureza humana e dos processos sociais, transformando as contradições da 
sociedade em desequilíbrios do ecossistema ou problemas de gestão capitalista dos "recursos naturais".

A disputa pela apropriação e controle da água vem se acentuando nos últimos anos, mais precisamente a partir da década de 1990, período no qual se consolidam os marcos da globalização da economia e das condições gerais de acumulação capitalista neoliberais. Referimo-nos ao modelo neoliberal e à mundialização como a materialização de novas conformações territoriais em múltiplas escalas da relação do capital. Ou seja, essa nomenclatura se refere a uma das periódicas mutações do capital.

Neste contexto de mais uma das periódicas mutações do capital forjam-se quatro paradigmas centrais para a "gestão" da água: 1) a produção da escassez (na medida em que algo é pensado e instituído como escasso, acredita-se que pode ser objeto de compra e venda, pode ser objeto de mercantilização, tornando a água mercadoria e privando homens e mulheres de seu acesso); 2) privatização na prestação dos serviços (diminuição de barreiras nacionais para a criação do negócio da água e "concessões" reguladas pelo mercado e pela lei da oferta e da procura); 3) controle de demanda e acesso sob a égide do mercado (considerase a água como recurso com valor econômico, ou seja, recurso hídrico, o discurso e as ações focam-se na cobrança da água como "chance de ouro" concentrando aplicações das finanças na qualidade de decisões, no gerenciamento e no planejamento estratégico de decisões); e 4) o foco na universalização e não na equidade no sistema de abastecimento de água (existem mais de trinta milhões de pessoas vivendo sem água potável no Brasil ${ }^{2}$ outros problemas estão imbricados a essa questão da universalização, como a intermitência no abastecimento, os problemas de racionamento de água, água sem qualquer tipo de tratamento, sem adição de flúor e sem vigilância dos órgãos de saúde pública. No Rio de Janeiro, apesar da aparência de universalização do sistema de abastecimento de água, a questão da ausência-ineficiência no sistema ainda é marcante nas favelas e nas periferias, conforme expõe a literatura sobre o tema. Consideramos que a situação é ainda pior nas favelas da periferia). Debatemos tais questões, esses quatro paradigmas, no primeiro capítulo do trabalho, intitulado Da crise das águas às águas da crise na periferia da metrópole capitalista.

O segundo capítulo da dissertação, A Ilusão da Transparência e a Ilusão da Opacidade na interpretação da questão social do abastecimento de água, consiste na análise

\footnotetext{
${ }^{2}$ Segundo dados do Censo do IBGE de 2000. Nos Resultados Preliminares do Censo de 2010 a situação estatisticamente melhorou, porém a quantidade da população sem abastecimento de água conectado à rede geral apresenta números expressivos. Existem quase 10 milhões de domicílios que não estão conectados a rede geral de água e mais de 4 milhões de domicílios que utilizam fontes "alternativas" de água. Veremos que "alternativo" é sinônimo de abastecimento de água crítico e precário.
} 
da ilusão da transparência (SOJA, 1993), refutando as interpretações que desmaterializam o espaço em ideação e representação puras, numa reflexão intuitiva e não material. Em contraponto a tais interpretações buscamos realizar a "abstração concreta" da análise materialista histórico-dialética, no qual a abstração é real, prática, logicamente anterior à abstração do pensamento, isto é, realizamos uma consciente aproximação do concreto exatamente na hora de abstrair.

Discutimos os processos de produção social do urbano das favelas da periferia do Rio de Janeiro. Verificamos que o proletariado urbano sofre um contundente processo de segregação sócio-espacial induzido em razão de políticas de remoção de favelas das áreas consolidadas e "valorizadas" da cidade e através do mercado de lotes em virtude do parcelamento de grandes glebas, o que repercutiu drasticamente em seu cotidiano.

A impossibilidade do urbano volta-se para a Zona Oeste da cidade do Rio de Janeiro. Desde o final da década de 1960 e início da década de 1970, a ela acorriam (como ainda acorrem) as classes sociais que não podiam resistir à especulação imobiliária e aos impostos cobrados nas áreas consolidadas da cidade (a cidadania realizada através do consumo de bensmercadorias e serviços-mercadorias). Em sua busca iam também removidos de favelas e migrantes que (já não) chegavam na metrópole com a esperança de morar próximo ao trabalho e desfrutar de bens e serviços que a cidade poderia oferecer-lhes. É a redistribuição perversa e espoliativa no/do espaço urbano, como condição imposta às classes sociais mais pobres.

Assim, podemos inferir numa postura abstrata concreta que há um processo de favelização da periferia carioca, iniciada na década de 1980 e radicalizada nas décadas de 1990 e 2000, concomitantemente à "remoção branca" que acontece nas áreas nobres e consolidadas da cidade, conforme inclusive ressalta Faria (2004).

A urbanização de favelas realiza também a ilusão da transparência, passando de resistência à negócio urbano. Apoiados numa aliança com os setores econômicos, o Estado substancia vital fôlego para a produção e reprodução do espaço, voltados prioritariamente às exigências e contingências da reprodução econômica. A aliança entre proprietários de terra, proprietários de capital e Estado realiza a dotação de infra-estruturas materiais, a criação de instrumentos fiscais, jurídicos e políticos para que a valorização do capital se efetive. Postergam-se e atenuam-se crises repassando o ônus da financeirização das produções e reproduções capitalistas, fundamentando o papel do planejamento para o desenvolvimento da economia de doutrina neoliberal. 
O Programa Favela Bairro, implementado na cidade do Rio de Janeiro na década de 1990, tornou-se a principal manifestação dessa virada no tratamento das questões urbanas e do problema habitacional do Brasil: valorizando favelas em áreas consolidadas da cidade e operando com o slogan da integração "favela-bairro" segue então o modelo de "ordenamento territorial", tentando "ordenar" a "desordem" e negligenciando a contradição. Percebeu-se que nas favelas da periferia do Rio de Janeiro a atuação do Programa Favela Bairro (programa de urbanização de favelas) foi catalisadora de uma espoliação perversa, de inserção precária do proletariado urbano e com urbanizações, sem a realização total ou parcial das obras.

Também no segundo momento da dissertação, a discussão acerca da ilusão da opacidade (imbricada a ilusão da transparência), conforme discutido em Soja (1993), reifica o espaço, induzindo a uma miopia que enxerga apenas uma materialidade superficial, formas concretizadas e elementos da paisagem que são passíveis apenas de mensuração e de descrição fenomênica. As interpretações que consideramos opacas são realizadas pelo aparelho de Estado e seus "procedimentos" técnico-burocráticos (IBGE, CEDAE, Plano Diretor e Planejamento Estratégico), por conceitos empreendidos por parte da Academia e pela mídia.

No terceiro capítulo, denominado A urbanização da sociedade e a mundialização do capital: processos e situações para compreender as favelas da periferia da cidade do Rio de Janeiro e o abastecimento de água como raridade, desenvolvemos mais explicitamente os momentos de trabalho de campo. Assim, tal como Martins (2004), nós não partimos das favelas como objeto de estudo, nós chegamos a elas por meio do movimento entre teoria e prática da nossa pesquisa, fundamentalmente, pois as favelas da periferia carioca mostraramse portadoras de situações reveladoras das contradições.

Compreendemos em um sentido político, social e econômico que é funcional e estrutural a manutenção da raridade da água para os moradores das favelas da periferia do Rio de Janeiro. A raridade da água é sinônimo de precariedade, ineficiência e intermitência e não necessariamente a completa ausência do abastecimento. Essa massa de expropriados (do campo para a cidade e de favelas das áreas centrais da cidade para áreas periféricas) convivem cotidianamente com essa raridade na reprodução de suas vidas. Seus locais de moradia e sociabilidades podem a qualquer momento de expansão econômica de áreas próximas sofrer outra expropriação de seus territórios devido ao processo de valorização do solo urbano do seu entorno seguindo os fluxos e vetores da reprodução da metrópole. Neste sentido, desvendar a urbanização trata-se de uma tarefa relacionada a desvendar este urbano que surge a partir da zona crítica (LEFEBVRE, 2001:87-88). 
O quarto capítulo, A mercadoria água e seus segredos, retoma questões discutidas ao longo da dissertação, e consiste numa tentativa de elaboração sobre a mercantilização da água, em uma leitura direta de Karl Marx. Neste capítulo, desenvolvemos que a mercadoria-água tem um fundamento: tornada raridade no discurso e na prática a partir da sua produção (baseada na criação de valor de uso social), é objeto de valorização. Percebemos que se estabelece uma contradição: a água é uma condição necessária à reprodução da vida e imprescindível à reprodução econômica, e sua condição de utilidade é anterior à sua necessidade. A mercadoria-água, porém, tem um fundamento pregresso à sua condição de mercadoria: sua dominação privada. Para se tornar mercadoria, ela se tornou antes propriedade privada ou estatal, e como parte da propriedade do proprietário de terras a água também constitui sua renda fundiária. Porém, quando se produz água potável ou água de reuso incorpora-se trabalho à água tornando-a portanto mercadoria. $\mathrm{O}$ valor de uso social criado é a sua condição de utilização fundamentalmente a partir das concessionárias de abastecimento público e privado, que instituem um preço a ser pago quando se consome a mercadoria-água. Esse movimento exige a interpretação de algumas relações fetichistas, partindo-se da mercadoria, mas não se limitando a ela para não estabelecermos um movimento mecanicista desse processo. Como uma mercadoria, a água se torna mais uma mercadoria na coleção monstruosa de mercadorias do mundo moderno, conforme argumenta Marx logo no início d'O Capital.

Finalmente, depois dessas reflexões descritas anteriormente, consideramos (dialogando com PAULA, 2007 e PRIETO e VERDI, 2009) que à Geografia cabe entender e revelar, nos seus fundamentos, o que move a ocupação, a apropriação e a produção do espaço no mundo contemporâneo, e não empenhar-se em uma conscientização ambiental autonomizada e fetichizada. Pois do mesmo modo como o conhecimento geográfico pode servir à constituição de políticas empresariais (filiada à manutenção constitucional e jurídica da barbárie capitalista) ou de um planejamento submetido à mercadoria (e reprodutibilidade econômica), pode ele também servir àqueles que se unem em torno da resistência contra as desmedidas da mundialização do capital que degrada (e monopoliza) a natureza e expropria os homens. Essa dissertação busca, então, contribuir para a análise crítica da crise capitalista, apontar alguns porquês da sede do capital sobre a questão das águas e também ao debate marxista, especialmente na Geografia. 
Nosso trabalho então rechaça as análises da Cidade Maravilhosa produzida como imagem-simulacro (MATOS, 1998), simulando e dissimulando a realidade, a partir da ênfase em pontos turísticos na mistura entre Carnaval, praia, Copacabana e futebol, positivando as contradições e a dialética. Também não analisamos a imagem-fetiche do Rio de Janeiro, explicitando objetos inanimados e imagens sem objeto, ou seja, a produção de uma análise morta, sem sujeitos sociais. Inserimo-nos contraditoriamente na análise tentando explicitar, tal como propõe Matos (1998), a construção parcial da realidade que a prática social da autonomização do espetáculo realiza.

A imagem-mercadoria (MATOS, 1998) da cidade do Rio de Janeiro tem como fundamento a alienação cultural e a alienação econômica da sociedade urbana. Essa imagem hipnótica do pensamento é uma acumulação de espetáculos, onde a realidade surge no espetáculo e o espetáculo é real (DEBORD, 1997). Na periferia carioca, sua realidade é negada, negligenciada, ocultada e escondida. O movimento inclusive é de autonomização da realidade e da vida dos moradores das periferias, das próprias periferias. Os interesses dos meios de comunicação de massa e de parte dos intelectuais por esses territórios ocorrem na medida em que a concretude precária da vida cotidiana possa ser espetacularizada. Assim, esses territórios, a pobreza e miséria cotidiana de seus moradores, a violência e a favela tornam-se espetáculos. Tentaremos então desvanecer com essa dissertação o âmago do irrealismo da sociedade real (DEBORD, 1997). Esforcemo-nos então.

\section{$* * *$}

Esse trabalho foi revisado em momento crítico na/da Universidade de São Paulo. Vivenciamos um profundo contexto de militarização da Universidade pública, crítica e livre e profunda criminalização dos movimentos sociais e suas lutas. Assim, diante desse processo marca-se o profundo repúdio às ações da Polícia, dos meios de comunicação de massa e da Reitoria no processo de desocupação da Reitoria da USP. Consideramos ainda que realizar um corte de classe nesse processo é uma tarefa importante e necessária. Relembrar que a moradia estudantil ficou sitiada na madrugada da invasão da tropa de choque é fundamental. Reafirmar que nós moradores do CRUSP ficamos sujeitos a cárcere privado pela polícia é tarefa basilar. Retomar que a construção do pensamento crítico e autônomo ainda se realiza em partes da Universidade e não sujeita as demandas tecnocráticas e burocráticas da meritocracia (e das agências de fomento), se mostra como parte substanciosa. Demonstrar que a democracia burguesa substancia-se num fetiche do espaço no qual a propriedade privada é 
reificada, enquanto os sujeitos sociais que reivindicam ocupações como uma denúncia sobre os rumos da sociedade (e no caso da Universidade) são criminalizados, é demanda urgente. Explicitar que a repressão e as torturas permanecem como marcas do processo de dominação econômica, financeira e social do capitalismo, no qual a polícia tem tarefa e papel substancial, pois mostra-se como marcas da presença-ausência do aparelho do Estado é questão fremente. A polícia militar é o aparato repressivo e instrumental da acumulação de capital, e transformar a USP em um parque cada vez mais elitizado faz parte de um processo muito maior. Muito mais complexo do que os meios de comunicação de massa informam. O processo de higienização e assepsia na USP segue a toque-de-caixa: criminalização do movimento estudantil, da moradia estudantil e seus moradores, fechamento da Universidade à população, etc. As lutas e reivindicações, porém, permanecem vivas e combativas! 


\section{Da crise das águas às águas da crise na periferia da metrópole capitalista}

\subsection{A crise urbana e a crise das águas}

Pela primeira vez na história da humanidade, em 2007, a população urbana ultrapassou a população rural em termos absolutos segundo dados da ONU (2007). No Brasil, pelo menos, desde a década de 1970 a população urbana brasileira superou a população rural. Formou-se o lócus da concentração do capital e da força de trabalho: as metrópoles e suas contradições. Todavia, o que colocamos em questão neste trabalho não são as taxas de urbanização, mas a elucidação dos conteúdos do processo que conduz à formação de uma sociedade urbana (CARLOS, 2008). A produção e reprodução de tais contradições podem ser observadas, por exemplo, na raridade ${ }^{3}$ de um conjunto de infra-estruturas e serviços básicos principalmente nas periferias e no processo de verticalização nas metrópoles com a possibilidade histórica da realização da renda de monopólio nas cidades (OLIVEIRA, 2003).

Assim, a análise da urbanização capitalista da sociedade (e a dialética imersão em tal processo social) demonstra, materializado na paisagem urbana, que há uma enorme massa de trabalhadores que não conseguem obter nem o suficiente para sobreviver nas cidades: habitar, se alimentar, saciar a sede. $\mathrm{O}$ urbano que engendrou o imaginário de emancipação humana representa, na crise urbana que estamos inseridos, a mais significativa inflexão entre homem e natureza e a sua impossibilidade para todos (DAMIANI, 2009, 2010). Tal ideal de emancipação humana consubstanciado no urbano, que contém dentre outros atributos a separação do homem da natureza e a mudança de qualidade nessas relações, não pode desconsiderar que quanto mais a sociedade se urbaniza, mais se impera extrair da natureza. Porém, o processo exploratório do modo de produção capitalista dá cada vez mais sintomas de que não pode resolver essas questões e apresenta como respostas paliativas telescopagens ${ }^{4} \mathrm{e}$ metáforas nas resoluções dos conflitos no que tange a problemática urbana.

O modo de produção capitalista fundamenta em sua forma-conteúdo e significado que há um êxodo sem volta que caracteriza nosso tempo: o espraiamento do urbano e da

\footnotetext{
${ }^{3}$ Tomamos raridade nos termos propostos por Lefebvre (2003): “o pão, os meios de subsistência, etc. Nos grandes países industrializados já há superprodução latente desses meios de viver que outrora foram raros que provocaram lutas terríveis em torno de sua raridade. E agora, não em todos os países, mas vitualmente à escala planetária, há uma produção abundante desses bens; não obstante, as novas raridades, em torno das quais há luta intensa emergem, a água, o ar, a luz, o espaço. É em função dessa luta que é preciso compreender o urbanismo, o que, apesar de suas fraquezas e fracassos, justifica em certa medida as pesquisas, as inquietações, as interrogações".

${ }^{4}$ Segundo ponderações de Damiani (2009) o termo foi configurado por Henri Lefebvre. A télescopage está no plano da produção de uma ilusão, de uma confusão, de um misto de realidade e representação, potencializado por transferência e redefinição de conteúdos, terrivelmente ativas.
} 
urbanização como processo social, tendo a cidade como sua forma mais acabada. Henri Lefebvre ainda na década de 1970 já ensejava a hipótese "da urbanização completa da sociedade. Hoje virtual amanhã real”.

Podemos dizer que estamos no olho do furacão, isto é, no centro de um movimento de transformações em nível global que, velozmente, vem concentrando a população nas cidades e submetendo parcelas significativas deste contingente à sobrevivência em condições indignas (MENEGAT, 2003). A urbanização capitalista é um processo de concentração (de homens, de produtos e de coisas) nas cidades, capaz de articular os sistemas hierarquizados das cidades, através de fluxos materiais e imateriais, numa convergência que deu forma à metrópole (SEABRA, 2005).

A urbanização, definida por Damiani (2003, 2009, 2010) como crítica, cujo fundamento subjetivo negado é a massa proletária das periferias metropolitanas, está sujeita aos avanços do capital imobiliário e de outras formas de capital, financeirizadas, e sob incentivo estatista, inclui a produção de representação da realidade turva entre a crise social e a crise ambiental, a partir de políticas de sustentabilidade, como imagética e ilusória de equilíbrio (DAMIANI, 2009). No que tange a tal discussão compreendemos que o abastecimento de água se encontra nessa órbita de debates, imerso em camadas espessas de metáforas, como desenvolvimento sustentável, educação ambiental ${ }^{5}$, consumo responsável ${ }^{6}$, preservação, isto é, a naturalização da natureza humana e dos processos sociais, transformando as contradições da sociedade em desequilíbrios do ecossistema.

Nas imensas periferias, as dos centros históricos e expandidos das cidades, ou as do seu entorno, cada vez mais amplo e distanciado, metropolitano, prevalece a baixa composição orgânica do espaço, que aparece como ausência de infra-estrutura urbana (DAMIANI, 2003; 2009). Inscreve-se o movimento da urbanização crítica: o distanciamento dos espaços

\footnotetext{
${ }^{5}$ A educação ambiental que se apregoa muito freqüentemente dá a (ilusão da) autonomia à questão ambiental, desvinculando-a do entendimento e da crítica da produção capitalista do espaço conforme argumenta Paula (2007).

${ }^{6}$ Nos últimos quinze anos, começou a ganhar relevância o discurso do consumo responsável pelo meio ambiente. Para Fontenelle (2010) esse discurso sugere um retorno ao universo da proibição social e da culpa que parecia banida de uma sociedade que havia rompido com quase todos os limites sociais. Tal fato está gerando uma nova mercadoria: a redenção. A autora afirma que há no mundo contemporâneo "a ideologia do eu autônomo", atualizada no discurso do consumo responsável, explicitado pela concepção de Slavoj Zizek de ideologia, sob o qual o sujeito é chamado "a decidir, mas ao mesmo tempo recebe a mensagem de que não está em posição efetiva de decidir" (ZIZEK, 2009:158 apud Fontenelle 2010). A ideologia virou prática nessa autonomização individualista e se materializa, por exemplo, no debate que Fontenelle (2010) critica sobre "consumo responsável". Tal debate sobre a ideologia como fantasia social, conforme afirma Zizek, explicita-se na crítica de Carlos Oropeza Aguilar (2010), engenheiro da Asociación de Sistemas Comunitarios de Agua del Sur (ASICA-SUR) criada posteriormente a guerra da água na Bolívia em 2000, associação responsável em mediar a gestão comunitária das águas em Cochabamba fora da lógica da reprodutibilidade econômica e da racionalidade estatal. Assim afirma Aguillar (2010) "tenemos el derecho de ser parte de la gestión, pero no cómo el modelo de 'observatorios ciudadanos', sino como parte de la misma gestión, tomar las decisiones".
} 
periféricos e a construção de novas centralidades econômicas metropolitanas, em um fenômeno em curso aparentemente paradoxal; ao lado de crises recorrentes do capital, assistese a uma das maiores expansões mundiais das relações sociais capitalistas, convertendo a maioria da população do planeta em mão-de-obra, disponível para o mercado e dele dependente. Dialeticamente concordamos com Fontes (2009): ao mesmo tempo há crise social e expansão do capital. Mészáros $(2002$; 2007) enfatizou o caráter de uma crise estrutural, demonstração da impotência atual do capital de acomodar as forças sociais que desperta e de frear a destruição social (e) da natureza a que a expansão das relações capitalistas conduz. O autor emprega o termo crise estrutural para contrapor-se à noção clássica das crises conjunturais do capital. Isso pode induzir a confundi-las, pois tais crises recorrentes integram a própria estrutura capitalista. A crise estrutural é a forma-conteúdo de reprodução ampliada do capital.

Contudo, Istvan Mészáros procura superar o sentido acoplado dos dois termos. Para ele crise estrutural não remete a um momento ou um ciclo conjuntural, nem característica estrutural da produção periódica de crises pelo capital, mas assinala uma virada qualitativa na qual a expansão capitalista passa a configurar-se como crescentemente destrutiva, aniquilando sua potencialidade de "destruição criativa", tornada destruição destrutiva, conforme Fontes (2009) percebeu ao analisar a obra de Mészáros.

Assumindo essa interpretação do trabalho de Mészáros, estamos diante de uma nova qualidade do capital contemporâneo, violentamente devastador. Essa abordagem permite ir além das crises clássicas (conjunturais) do capital e do capitalismo, apontando para uma nova situação permanentemente crítica do conjunto da vida social. (MÉSZÁROS, 2002; 2007; FONTES, 2009). Percebemos que o tempo de reposição do capital é (im)possível, e que há uma aceleração cada vez mais intensa da reprodução do capital. A crise estrutural no sentido definido por Mészáros não significa redução ou enfraquecimento do capital, mas resulta da expansão do metabolismo social sob o capital. O cerne de sua reflexão aponta para o fato de que a generalização da reprodução do capital lança a humanidade em permanente destruição/esgotamento/extinção: risco de aniquilação do homem, destruição ambiental, crescente perda do valor de uso da produção material, financeirização da vida cotidiana, crise do trabalho, subordinação de massas crescentes de trabalhadores ao capital, resultante de múltiplas expropriações que lançam regularmente enormes setores da população para uma situação crítica.

O solo urbano de uma economia extremamente financeirizada realiza tal situação, envolvendo inclusive negócios urbanos. É a urbanização como negócio e o urbano como 
mercadoria. Realizados, inclusive, nas periferias urbanas formadas por loteamentos clandestinos, favelas, precários conjuntos habitacionais, loteamentos populares autoconstruídos, estruturalmente deficientes quanto às condições urbanas, que só assim se reproduzem, como argumenta Damiani (2003). Em uma estrutura que passou da urbanização como resistência contra os processos de remoção até a realização da urbanização como negócio e forma-conteúdo de expulsão do proletariado urbano e de sua inserção precária no urbano do mundo da mercadoria, vemos que a integração precária e perversa não é mais descartada como forma de reprodução (crítica) da vida dos trabalhadores, ela é transformada em política pública pelo aparelho do Estado.

Assim, urbanizar esses fragmentos do espaço corresponde a selecionar quem recebe tais melhorias. Isso equivale ao mesmo tempo à expulsão de uma parte da população ali fixada. A primeira adequação será a expulsão daqueles cuja posse é irregular; seguida pela redução da ocupação por moradias, em prol de espaços institucionais e viários (DAMIANI, 2003). Em suma: urbanizar essas áreas é reduzir, no mínimo e ao mínimo, o número de moradias, e selecionar, tal e qual receberá a dotação de infra-estrutura, fomentando a competição entre favelas, loteamentos e conjuntos habitacionais que receberão as obras, além da competição pelas benesses dentro dos territórios da favela. É preciso ainda frisar as questões referentes à valorização do imóvel após tais urbanizações, isto é, ampliação dos custos da cidadania realizada via consumo e negócio: pagamento de água, esgoto, luz, que são outros elementos de expulsão ${ }^{7}$ dos mais pobres dentro das tessituras da pobreza.

Assim, as periferias estão cada vez mais plásticas, se espraiam e conformam o que Damiani $(2003,2008)$ observa como acumulação primitiva de espaço, ou seja, no momento em que se inquire a utilização de tais espaços para a produção de moradia de classes médias e altas, empreendimentos financeiros, especulação de terrenos para a construção de estruturas para mega-evento, grandes estabelecimentos industriais ou mesmo a urbanização de favelas sem regularização fundiária se realiza a expulsão dos moradores para localizações ainda mais

\footnotetext{
${ }^{7}$ Há também certo desinteresse do tráfico de drogas pelo domínio territorial de parte da favela que foi urbanizada. Geralmente durante a realização das obras do programa de urbanização de favelas no município do Rio de Janeiro (Favela Bairro) ocorreram embates, segundo nos relataram os técnicos das Secretarias de Urbanismo e Habitação. Os traficantes exigiam modificações no traçado das obras, a contratação de pessoas ligadas às ações do tráfico, ou mesmo a não realização de qualquer obra na favela. A presença e as intervenções do Estado, tais como aumento do efetivo policial, realização de obras viárias e presença da mídia são problemáticas para a "rotina do tráfico". Quando ocorre a urbanização, como no caso da favela das Três Pontes, localizada na Zona Oeste da cidade do Rio de Janeiro, a facção (Terceiro Comando Puro - TCP) que detém o controle da favela não considerava a área que sofreu intervenções (uma pequena parte da favela) mais um local estratégico para a realização de seus negócios. Segundo moradores da área entrevistada, tal local passou a ser alvo de assaltantes pertencentes a favelas de outros comandos. Os moradores reclamaram com o gerente da boca de fumo que ordenou a presença de "olheiros" (de cerca de 10 a 15 anos, com "modernos" rádios Nextel) para vigiar a área, e também a presença da "moto do tráfico" para intensificar a fiscalização.
} 
distantes na periferia. Ou, se realizam projetos em que a participação dos moradores serve como um momento pró-forma, não se realizando nenhuma alteração nos projetos após as audiências públicas ocorridas nas favelas que sofrem intervenções urbanísticas (conforme relato de arquiteto que trabalhou em projetos de urbanização de favelas na década de 1990).

Ruth, moradora de uma área dentro da favela das Três Pontes na cidade do Rio de Janeiro que foi urbanizada em 1996, relata:

Com o [Programa] Favela-Bairro temos tudo. Pagamos água, luz, telefone, e nada disso funciona. Eu pelo menos nunca vi um funcionário da CEDAE, Light aqui. Dizem que eles aparecem, olham o problema e vão embora, mas eu nunca vi... Agora, a conta chega todo mês.

O cotidiano urbano prolonga e explicita o sentido da urbanização capitalista pela generalização de um modo de vida no qual foram aprofundadas as separações no âmbito da vida social (SEABRA, 2005), conforme, por exemplo, lembram Maria da Penha Gomes, 56 anos, diretora da associação de moradores da favela do Jacarezinho e Valdir Claudino, morador da favela da Mangueira sobre a centralidade da falta d'água em sua vida cotidiana em depoimentos ao Projeto Favela tem Memória:

Aqui na favela só caía água depois da meia-noite. E olhe lá! As pessoas tinham que sair de casa depois do jantar para guardar lugar na fila. Isso era todo dia, não tinha descanso. (Maria da Penha)

Eu fazia seis viagens por dia carregando duas latas de vinte litros. Usava um pano nas costas para proteger, mas mesmo assim machucava. (Valdir)

Compreendemos então o urbano (a sociedade urbana) como totalidade, produto de um processo de produção num determinado tempo histórico. Esse processo é uma realidade que se generaliza, numa escala da cidade à metrópole, e como virtualidade se espraia para a sociedade inteira (LEFEBVRE, 2008a). A cidade representa trabalho materializado, produto da divisão técnica e social, materialização da história dos homens, da realização da vida cotidiana, das fissuras do acontecer e forma de apropriação do espaço urbano produzido. A cidade não é mero suporte de processos sociais e econômicos, mas parte decisiva da produção e reprodução do capital (CARLOS, 2003).

No bojo de tais questões emerge a discussão de Lefebvre (2008b) sobre o direito à cidade, que "manifesta-se como forma superior dos direitos: direito à liberdade, à individualização na socialização, ao habitat e a habitação. O direito à obra (a atividade participante) e o direito à apropriação (bem distinto da propriedade) se imbricam dentro do direito à cidade". Seu par dialético presente é a negação ao direito à cidade, materializado nas formas de segregação urbana balizadas por quatro processos imbricados, que Marques (2005) sistematiza: 1) pela dinâmica do Estado e das políticas públicas, 2) pelo mercado de terras, 
loteadores e incorporadores urbanos na produção de moradias, 3 ) pela dinâmica econômica e 4) a crise do trabalho e a ordem jurídica brasileira.

Soja (1993) realça enfaticamente que a sobrevivência do capitalismo está baseada na criação de uma espacialidade cada vez mais abrangente, instrumental, e também socialmente mistificada, escondida da visão crítica sob véus espessos de ilusão, ideologia e da "transparência" do espaço geográfico. O que distingue, então, o gratuito véu espacial do capitalismo das espacialidades de outros modos de produção é sua produção e reprodução peculiares de um desenvolvimento geograficamente desigual.

Assim, a Geografia que vamos discutir tem o intuito de contribuir com o elucidar dos aspectos do processo social de modernização ${ }^{8}$ e de mundialização do capital (CHESNAIS, 1998), dialogando com pressupostos de Damiani (2009), que esse processo atinge a todos, mesmo os lugares mais afastados de sua centralidade. Tal processo é inerentemente desigual, sendo que compreendemos que as desigualdades no acesso ao abastecimento de água são um dos prismas de observações dessas desigualdades.

No processo de urbanização crítica o acesso à água tem como marca principal a forte desigualdade socioespacial, beneficiando as camadas de maior renda, observando-se a recorrência da ausência e/ou precariedade de atendimento para as favelas e para as periferias (VETTER, 1979; MELLO, 1989; KLEIMAN, 2002; SANTOS Jr., 2007; BRITTO, 2009; MARQUES, 2000).

Trata-se de um padrão de distribuição regressivo, conforme chamam a atenção Kleiman (2002) e Marques (2000). Por um lado, observa-se uma política para redes de infraestrutura completas com nível satisfatório de serviços sendo constantemente renovadas e expandidas e tecnicamente sofisticadas nas áreas em que há um nexos entre os interesses do capital financeiro-imobiliário e a moradia de camadas de maior renda. Assim sendo, as áreas ditas "nobres" tornaram-se cada vez mais "nobres". (MACHADO, 2004; KLEIMAN, 2002). Por outro lado, o Estado exime-se de prover acesso aos serviços para as camadas de baixa renda. Institui-se uma política deliberadamente espoliativa na qual destaca-se a ausência de redes completas, o não-provimento de serviços ou seu mal provimento com uma configuração lenta, descontínua, sem manutenção e com problemas de operação em áreas de residência das classes sociais mais pauperizadas, principalmente em favelas e loteamentos das periferias

\footnotetext{
${ }^{8}$ A modernidade é produzida pelo capitalismo contemporâneo e dominada pelo princípio do desempenho. Sua temporalidade não é a da experiência, do conhecimento, da felicidade; ela é institucionalmente organizada e este é "o atributo mais eminente da dominação" - o que corresponde a um encolhimento do "espaço de experiências" na vida social e de liberdade; liberdade de acesso ao passado e ao futuro como construção de uma subjetividade democrática (MATOS, 2007).
} 
distantes. Essas áreas em princípio sem interesse para o capital financeiro-imobiliário ficaram excluídas da conexão com as redes durante mais de seis décadas conforme descortinaram Vetter (1979), Santos (1981) e Kleiman (1996; 2002).

A concepção presente no arcabouço jurídico do Estado é a participação restrita e contida no discurso retórico, que complementa uma política de caráter assistencialista: "as favelas não fazem parte do mundo urbano da cidade oficial/legal e precisam ser resgatadas" (conforme afirma em entrevista o arquiteto da Coordenadoria de Macro Planejamento da Prefeitura do Rio de Janeiro). O "resgate" seria realizado pela "urbanização racional" de seus lugares de vivência. Para o Estado, estes lugares foram construídos, suas moradias e modos alternativos de acesso a água, "de maneira errada", tecnicamente desordenada e esta forma técnica errada é um dos elementos da "marginalização" dos indivíduos que ali vivem (KLEIMAN, 2002). O Estado e as agências multilaterais que o financiam acreditam que o provimento de serviço de água e esgoto através de redes oficiais fariam a transição das favelas para o "mundo urbanizado" 9 . E a formulação de políticas públicas incorpora tal corpus de atuação para o provimento de rede de água para tais espaços.

A disputa pela apropriação e controle da água vem se acentuando nos últimos anos, mais precisamente a partir da década de $1990^{10}$, período no qual, no que tange aos debates

\footnotetext{
${ }^{9}$ Menegat (2003) afirma que uma das gêneses do capitalismo é o forjar de um corte obtuso entre o "mundo urbano" que submete um "mundo rural". O próprio pressuposto da separação dual cidade-campo como dois universos díspares é veementemente criticado pela autora. Dessa forma, o cercamento dos campos e o dizimar de populações com formas comunais de apropriação da terra nos países centrais e a invasão do território e o extermínio de povos nativos nos países periféricos produzem o discurso dessa submissão. O campo como produtor de matéria-prima e mantenedor do modo de vida urbano, e as cidades como pontos de acumulação primitiva do capital e lócus da produção fabril. Alentejano (2010:1) expõe brilhantemente essa situação da urbanização crítica na periferia do capitalismo, após as enchentes e deslizamentos ocorridos no Rio de Janeiro em abril de 2010. "A raiz do problema está na forma acelerada com que se expulsou do campo brasileiro no último século mais de 50 milhões de pessoas. A perpetuação do controle das terras pelo latifúndio e a modernização deste estão na origem da expulsão desta enorme massa de trabalhadores rurais, os quais foram precariamente absorvidos pelas grandes cidades brasileiras. A histórica reivindicação da reforma agrária foi não só negada, como substituída por uma política de incentivo ao desenvolvimento de tecnologias poupadoras de mão-de-obra no campo, levando ao aumento da concentração fundiária e ao desemprego e subemprego generalizados no campo e à conseqüente expulsão de grandes contingentes de trabalhadores rurais para as cidades. E para onde foram estes trabalhadores? Para as áreas das grandes cidades que não interessavam ao grande capital imobiliário, por conta dos custos de produção mais elevados: as encostas dos morros e as várzeas dos rios. Não porque inexistam espaços urbanos vazios em melhores condições para a moradia destas pessoas, mas porque estes vazios estão controlados pelo capital imobiliário, aguardando a valorização destas áreas. Da mesma forma, há um sem número de prédios e apartamentos vazios nas nossas grandes cidades, mas estes não podem ser ocupados por estas pessoas, pois o 'sagrado direito de propriedade' garante o direito dos proprietários de mantê-los vazios, mesmo que isto signifique empurrar milhares de pessoas para morar em áreas 'de risco"” (grifos nossos).

${ }_{10}$ Porto-Gonçalves (2006; 2008) argumenta que ainda que a ONU tenha realizado em 1977 a Conferência de Mar del Plata para tratar da água, o tema permaneceu sem maior relevância até os anos 1990. Documentos internacionais importantes tratando da questão ambiental, como O Nosso Futuro Comum (1987), a Agenda XXI (1992) e a Carta da Terra (1992), chegam a surpreender pelo tratamento tímido que a água mereceu, sobretudo, quando comparamos com o destaque que vem tendo a partir da segunda metade dos anos 1990, a ponto de a água ser apontada como a razão maior das guerras futuras. A Conferência Mundial das Nações Unidas sobre Água e
} 
acerca da questão das águas, se consolidam os marcos da globalização da economia ${ }^{11}$ e das condições gerais de acumulação capitalista neoliberais. Referimo-nos ao modelo neoliberal e à globalização como a materialização de novas conformações territoriais em múltiplas escalas da relação do capital. Ou seja, essa nomenclatura se refere a uma das periódicas mutações do capital.

Neste contexto de mais uma das periódicas mutações do capital forjam-se quatro paradigmas centrais para a gestão da água ${ }^{12}: 1$ ) produção da raridade e produção discursiva da escassez; 2) controle de demanda e acesso sob a égide do mercado (recurso com valor econômico, ou seja, recurso hídrico); 3) privatização na prestação dos serviços, e 4) o foco na universalização e não na equidade no sistema de abastecimento de água. Vejamos essas telescopagens a seguir.

\subsection{A produção da raridade ou a produção discursiva da escassez}

Apesar do súbito e recente interesse mundializado pela problemática das águas, a questão da raridade da água já era sentida pelos mais pobres há muitos anos. Quando a questão se circunscrevia em seus efeitos mais danosos às classes sociais mais pobres, manteve-se apenas como instrumentalização da miséria a partir das políticas das bicas d'água

Meio Ambiente (Dublin, janeiro de 1992), uma das diversas reuniões preparatórias para Conferência das Nações Unidas sobre Meio Ambiente e Desenvolvimento (Rio de Janeiro, junho de 1992), dentre os quatro princípios que formulou, dois estabeleceram os critérios básicos para a gestão de recursos hídricos no século XXI: "a água é um recurso finito e vulnerável, essencial para a manutenção da vida, do desenvolvimento e do meio ambiente" e "a água tem valor econômico para todos os seus usos e deve ser considerada como um valor econômico". Esses dois princípios modelaram as ações subseqüentes em termos de gestão de recursos hídricos, estimulando o uso parcimonioso da água e atribuindo a ela a conotação de "commodity". Verdadeiro contra-senso entre os termos. No Brasil, a resposta veio através da promulgação de uma ampla legislação entre as quais a Lei $n^{\circ} 9.433$ de 08 de janeiro de 1997, que instituiu a Política Nacional de Recursos Hídricos e definiu a estrutura jurídicoadministrativa do Sistema Nacional de Recursos Hídricos, a Lei no 9.984 (julho de 2000) que criou a Agência Nacional de Águas, a Resolução CONAMA nº 17 (maio de 2001) que definiu critérios gerais para a outorga de direito de uso de recursos hídricos. A Lei 9.433, estabelecendo que "serão cobrados os usos dos recursos hídricos sujeitos à outorga...” (Art. 20, Seção IV).

${ }^{11}$ O processo de globalização ou mundialização do capital (CHESNAIS, 1998) é, antes de tudo, um processo de produção de mercadorias, isto é, uma produção destinada a troca desde seu início. Esse movimento imprime sua marca a todos os aspectos desse processo, estejam onde estiverem localizados os centros produtivos (OLIVEIRA, 2010). Para designar o estágio atual do modo de produção capitalista, Chesnais (1998) desenvolve o argumento da mundialização financeira a fim de explicitar a emergência de um espaço financeiro mundial, resultante da liberalização e da desregulamentação iniciada pelos Estados Unidos nos anos setenta do século XX.

${ }^{12}$ As expropriações primárias (da terra) e secundárias (de direito das águas, da vida biológica e humana através das patentes, etc.) se aprofundaram em velocidade inédita nas últimas décadas, em proporções diversas segundo os países (FONTES, 2009), mas atingindo a todos, fundamentando um desenvolvimento geográfico desigual e combinado (SMITH, 1988). Essas expropriações não são um fenômeno meramente econômico, ainda que sejam impulsionadas pela expansão econômica do capital. Constituem a base da vida social e de uma sociabilidade altamente contraditória, pois dependente (e necessitada) da expansão do capital para sua sobrevivência e, ao mesmo tempo, prova gritante de que essa expansão recompõe sem cessar a degradação que se imaginava superar (FONTES, 2009). É o que Mészàros (2002) chama de mecanismos de administração das crises que se realiza por intermédio da linha de menor resistência do capital. 
e da indústria (e geopolítica) da seca. A questão da água se apresentava como um problema manipulado na escala local particularmente pelas oligarquias latifundiárias no campo ou pelos representantes eleitos com políticas mitigadoras de pequenas melhorias no espaço urbano. Esses sujeitos sociais (com seus amplos interesses de classe) manipulavam secas e bicas. Atualmente, a projeção da discussão das águas enseja "atores na escala global" (PORTOGONÇALVES, 2008), ou melhor, novos sujeitos na mundialização do capital, que manejam o novo discurso da escassez através da governança, da gestão e do controle ao acesso à água, responsabilizando povos, culturas e tradições pelos problemas ditos ambientais. Os interesses de classe na reprodutibilidade econômica a partir das águas, todavia permanecem os mesmos.

Na tentativa de mitigar os efeitos da destruição destrutiva do capital rearranjam-se as questões sociais na forma de pagamento pelos "serviços ambientais" na nova rodada de acumulação do capital através da natureza. As grandes empresas privadas, o Estado, os moradores de determinadas áreas, sejam as classes sociais mais ricas ou pobres, indígenas, quilombolas ou camponeses são os responsáveis pela degradação das águas, são "poluidorespagadores". Assim, se dá a responsabilização das questões sociais transmutadas em problemas ambientais: é a redenção da crise estrutural como mercadoria (FONTENELLE, 2010).

Não negligenciamos que estamos diante do aumento da indisponibilidade de água em certas regiões do mundo, num complexo panorama da urbanização da sociedade: poluição das águas, degradação de mananciais, desperdício de grandes vazões de água, etc. (PORTOGONÇALVES, 2006; ALTVATER, 1995). Paradoxalmente, em localidades como Mumbai, na Índia, adutoras atravessam as favelas (como o exposto na Figura 1, na favela de Mahim), onde não há água, para abastecer áreas valorizadas das cidades. Constantes vazamentos nas proximidades das favelas foram observados nos trabalhos de campo realizados na periferia da cidade do Rio de Janeiro (Figura 2), e em muitas dessas áreas os moradores ficam sem água durante meses, ou nunca tiveram a água encanada em suas residências. Mesmo cidades como Istambul, com mananciais de água caudalosos que fazem parte da paisagem, apresentam boa parte da sua população nas periferias (sobre)vivendo com abastecimento de água negado, cotidianamente. 


\section{Abastecimento de água negado cotidianamente}

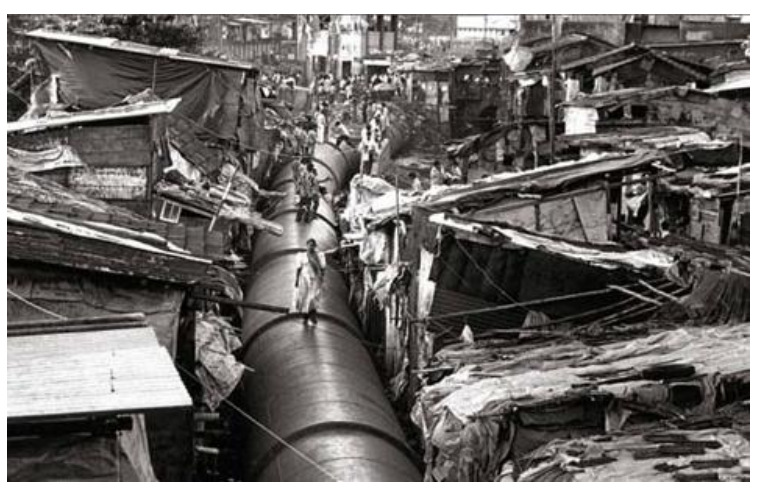

Fonte: SALGADO, Sebastião. Êxodos, 1995

Imagem 1: Duto d'água que passa pela favela de Mahim, levando água para os bairros ricos de Mumbai, Índia.

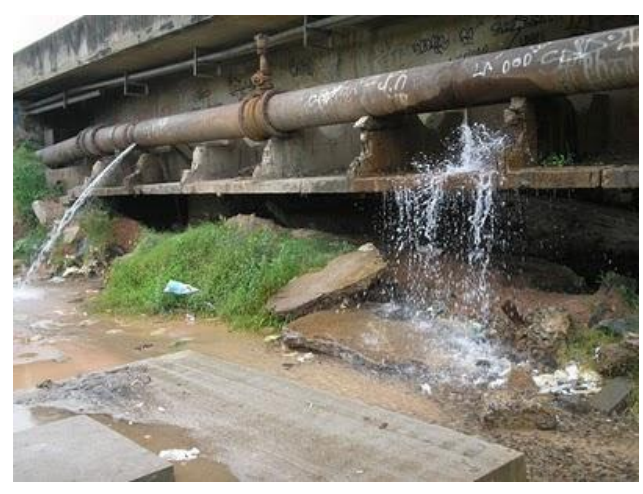

Fonte: CEDAE, 2010

Imagem 2: Vazamento de água em tubulação da Companhia de Águas e Esgotos do Rio de Janeiro (CEDAE) na periferia da metrópole carioca.

Contudo, o que esses fatos da vida cotidiana revelam: os efeitos da indisponibilidade de água estão longe de serem distribuídos igualmente pelos segmentos e classes sociais e territórios, assim como estão muito desigualmente distribuídos os meios para lidar com a questão. Também há diferentes formas de lidar com a água entre povos, (particularmente os indígenas), classes sociais (especialmente os camponeses) e culturas que são alijadas dos processos de autonomia e decisão sobre o acesso a água. Há uma reafirmação entre esses povos e classes sociais de que a água é essencial para a reprodução da vida, a água é dinâmica.

O ciclo (abstrato) da água, porém, é apresentado sem a imbricação dialética sociedade e natureza. A discussão deveria inserir e verificar como o campo (e sua relação dialética com a cidade), os processos de industrialização e urbanização e as diferentes classes sociais se inserem no ciclo da água. As produções agrícolas, os sistemas industriais, o urbano e a vida ${ }^{13}$

\footnotetext{
${ }^{13} \mathrm{Na}$ América do Sul encontram-se quatro das principais reservas de água do mundo: as águas costeiras; a Bacia Amazônica e a Bacia do Prata, consideradas as duas maiores vazões hidrográficas da face da Terra; e o Aqüífero Guarani, considerado a maior reserva de água mineral do mundo, localizada no subsolo do Brasil, Argentina, Paraguai e Uruguai. Nesta região, empresas privadas (especialmente empresas transnacionais) estão comprando áreas localizadas exatamente nos principais pontos de afloramento e recarga de água (MAB, 2006). A água é fundamental à indústria, à agricultura e a toda vida humana. Hoje, se consome, em média, cerca de $70 \%$ de toda água potável do mundo na agricultura, $20 \%$ na indústria e $10 \%$ no consumo doméstico. Devido às técnicas agrícolas de irrigação intensiva, mais de 45 milhões de hectares de terras já foram danificados. Todavia, nos países centrais industrializados (Estados Unidos, Europa, Japão, etc.) suas águas estão bastante contaminadas. Tudo indica que nos próximos anos a disputa pelo controle das águas potáveis estará no centro das disputas e conflitos (MAB, 2006; REVERS e MALVEZZI, 2009). As melhores terras agrícolas, principalmente para produção de agrocombustíveis, e/ou para celulose e/ou para produção das commodities agrícolas, e as melhores reservas hídricas localizadas nos países latinos, então sendo amplamente disputadas por grandes empresas multinacionais e por grandes proprietários de terra (muitas vezes encarnados nas mesmas pessoas). Shiva (2006)
} 
são partes constituintes do "ciclo", e não somente fatores externos atingidos pelos efeitos do uso da água, elemento natural e abstrato que deve ser preservado.

\section{O ciclo da água sem a imbricação dialética sociedade-natureza}

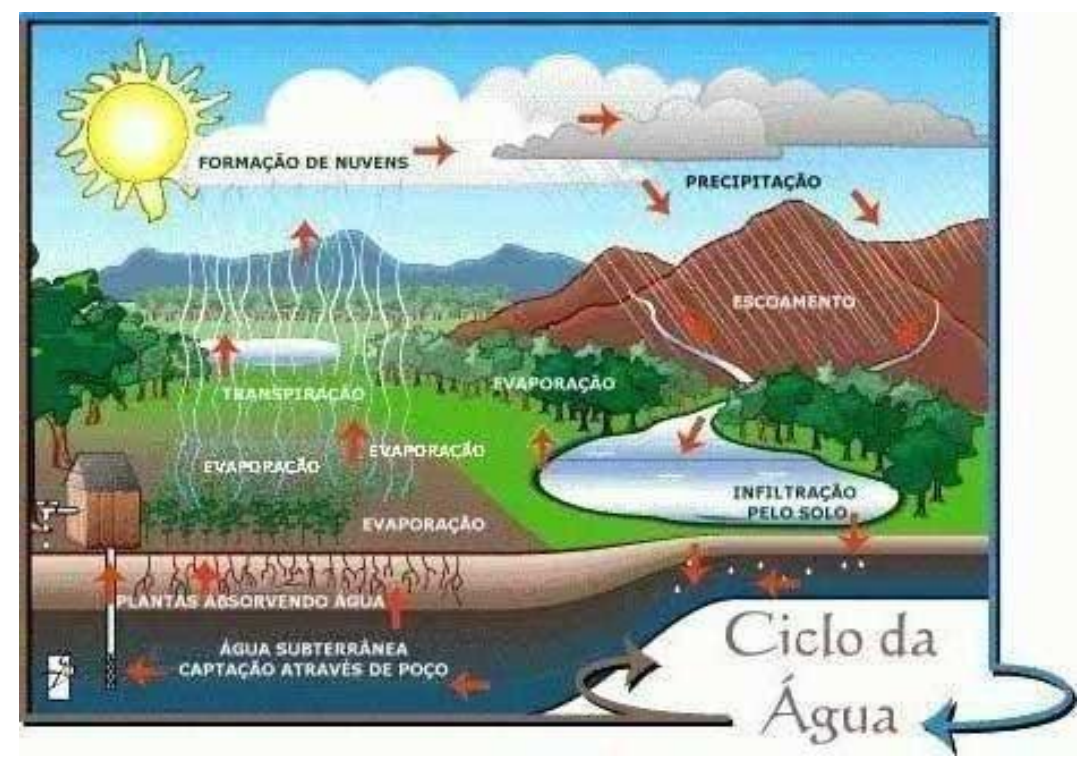

Fonte: Paiva, 2009.

Imagem 3: O ciclo da água. Naturalização de um processo que é também social.

O ciclo hidrológico, ou ciclo da água, não deve ser tomado como uma "totalidade fechada" (LEFEBVRE, 1981), pois é apenas um momento didático para uma aproximação do entendimento da dinâmica das águas. Entende-se ainda que no conceito de ciclo hidrológico há intencionalidades ligadas à instrumentalização técnica da ciência com pressupostos de modelos universais atrelados à argumentos empiristas-lógicos de razão e ciência, propagada por sub-disciplinas como a hidrologia, a engenharia hidráulica, geografia física entre outras e são estruturais para os processos produtivos do agronegócio, dos capitalistas industriais e da construção do negócio da mercadoria-água. Ressalva-se que dialogamos com as críticas de Bezerra (2011), Swyngedouwn (2004) e Felippe (2010), em que a idéia de ciclo porta consigo a noção de repetição, isto é, de um retorno ao mesmo ponto, ou ainda, início e recomeço de certo movimento, neste caso o movimento das águas. Movimento que na verdade é inerte. Para nós, os movimentos de matérias e fluidos inerentes aos processos do chamado "ciclo hidrológico" não devem ser limitados ao retorno da água à crosta terrestre ou a sua

por exemplo apresenta inúmeros casos de dominação privada da terra e das águas pelo mundo. No caso dos rios, especialmente no Brasil, o interesse principal é para construção de hidrelétricas, para gerar energia barata, para utilizar na extração dos minérios e do agronegócio (MAB, 2006; PORTO-GONÇALVES, 2006). 
evaporação, condensação ou infiltração da água no solo. Estas etapas são tradicionalmente observadas separadamente retratando o forte caráter positivista implícito neste esquema didático (BEZERRA, 2011).

Não se pode olvidar que a água é dinâmica e cada vez mais passa de riqueza natural à mercadoria, sendo monopolizada como mercadoria-água (aprofundaremos essa discussão no capítulo 4). Sob ação humana, a água captada em um determinado local rompe o ciclo hidrológico de sua bacia de origem, entra em novo ciclo de movimentação (FELIPPE, 2010) como uma riqueza natural ou como uma mercadoria, e se insere na dinâmica hidrossocial (isto é, nas relações imbricadas entre homem e natureza) para ser incorporada não somente em outra bacia hidrográfica (como argumenta FELIPPE, 2010) mas na lógica de reprodução do capital e na reprodução da vida ${ }^{14}$, englobando uma nova dinâmica da água.

Especialmente sobre a água como uma riqueza da natureza, podemos observar uma passagem do uso de suas propriedades físicas como meio de vida para a criação de valor de uso social que possa ser trocado como meio de produção. Essa passagem é realizada entre outras formas, pelas empresas transnacionais de água engarrafada que captam água em uma determinada bacia - com inúmeros conflitos - e que são vendidas em outras áreas para classes sociais sedentas por água potável de "qualidade". Transposições de bacias hidrográficas são também "comuns" (“naturalizadas") modificando fluxo, volumes e tradições de comunidades ribeirinhas, povos indígenas, dentre outros, atendendo às demandas dos capitalistas sedentos pela água que possibilita uma renda diferencial para suas terras e os habilita a um abocanhamento maior da massa de mais valia (absoluta), etc. Assim, compreendemos que as modificações de qualidade e quantidade da água como riqueza natural são características das pilhagens e desmedidas do capitalismo no processo de apropriação e propriedade privada da terra e das águas.

Para a reprodução da vida, a falta d'água modifica substancialmente a vida cotidiana, assim como sua intermitência e sua má qualidade. Esse processo combina a monopolização e a alienação da terra e das riquezas naturais (a natureza, não por acaso vista como uma externalidade) com a separação do trabalho e seus pressupostos materiais. Essa separação consubstancia as forças produtivas como forças destrutivas do trabalhador (assolado desmedidamente pelo trabalho precário) e desvincula radicalmente homem e natureza (DAMIANI, 1984). Essas separações também substanciam uma ilusão de autonomia dos

\footnotetext{
${ }^{14}$ Damiani (1984) argumenta que quanto mais o mundo sensível é apropriado pelos homens mais se vê que para a maioria dos trabalhadores, lhes parece (e é) que a natureza é do outro, pois são privados dos meios de vida (que garantem o trabalho e a subsistência).
} 
indivíduos e de produção universal de mercadorias com o fetiche das mercadorias, opacificando e ocultando as classes sociais e as lutas sociais. Damiani (1984) argumenta também que no bojo desse movimento aparecem a coletividade ilusória e o pretenso interesse comum camuflando os interesses particulares; a transformação e a preservação da natureza como frutos da vontade e aparentemente autonomizadas e independentes dos interesses reais, e a produção da natureza (SMITH,1988) como algo exclusivamente natural, ocultando sua apropriação diferenciada que torna a natureza passível de ser comprada, trocada, vendida e financeirizada. A raridade da água já demonstra nesse processo sua situação permanentemente crítica.

Porém, observemos a questão por outras lentes de compreensão desse mesmo processo. Estamos imersos num desafio político em que a atmosfera da crise da água se materializa também em diferentes matizes, como por exemplo, os conflitos de tensão militar tal e qual em países como Israel e Síria na disputa pelo domínio das Colinas de Golã, ou entre os povos curdos (espalhados entre a Turquia, a Síria e o Iraque) que lançaram movimentos nacionalistas através do Partido dos Trabalhadores do Curdistão (PKK) em 1989. Os curdos enfrentaram forte resistência do primeiro-ministro turco que ameaçou usar a água contra os militantes, cortando todo o fornecimento da vizinha Síria (epicentro dos conflitos e dependente da bacia que corta tanto os territórios turcos quanto o Estado sírio) caso não demovesse o movimento em seu país. Ou ainda o projeto de criação do rio artificial Saddam que desviou águas dos rios Tigre e Eufrates e transformou 57\% das áreas antes pantanosas em terras secas ameaçando a sobrevivência dos "árabes dos pântanos”. Estes declararam contra os iraquianos o que chamaram de jihad hídrica (com inúmeros conflitos de tensão militar na região - segundo demonstra SHIVA, 2006).

A crise se consolida também peremptoriamente nas disputas no interior da Organização Mundial do Comércio, nas discussões em Davos, nas reuniões do Banco Mundial e do FMI (PORTO-GONÇALVES, 2006; 2008) onde se decide um novo "código das águas" que quer torná-la mercadoria, e para isso é preciso privar os homens e mulheres do acesso a ela. Mas as decisões feitas nesses fóruns da mundialização do capital não podem prescindir da materialidade concreta da água para mover a agricultura, a indústria, a cidade e a vida (SHIVA, 2006). Assim, há que concretamente se apropriar da água nos lugares onde ela está e onde também estejam populações com outros usos da água para a reprodução da vida.

Os conflitos quanto aos usos da água tendem, portanto, a se aguçarem no contexto de relações sociais e de poder desiguais que caracterizam o mundo contemporâneo. PortoGonçalves (2008) ressalta que é preciso atenção frente à essa questão da água, pois não será 
necessariamente sob a forma de aquedutos ou de navios que veremos a água ser drenada das regiões e países periféricos para as regiões e países hegemônicos, e sim pelos volumes de grãos e de matérias semi-industrializadas: numa geografia desigual dos proveitos para uns e dos rejeitos para a maioria ${ }^{15}$. Novas expropriações são marcas presentes nesse processo.

Nakamura (2010) argumenta que a sociedade capitalista não pode deixar de consumir e produzir, por isso um processo de produção tem de percorrer, continuamente, sempre de novo as mesmas fases. Assim, em sua "conexão contínua" e "fluxo constante" de "renovação", todo processo de produção social é, ao mesmo tempo, "processo de reprodução". A expropriação, então, não é um momento devastador localizado no passado. Articulado à exploração da força de trabalho numa forma jurídica contratual de pagamento de salário e extração da mais valia do trabalhador, a acumulação originária é um momento constitutivo do capital, uma tendência inscrita no processo de valorização do valor fundado na permanente e ampliada subordinação do trabalho vivo ao trabalho morto (HARVEY, 2005; GILLY E ROUX, 2009). O processo de acumulação originária se recria incontáveis vezes: a acumulação por despossessão (espoliação) nos termos de Harvey (2005) é reinterpretada de modo a reintroduzir no interior do sistema completo do capitalismo as práticas violentas que caracterizavam sua pré-história externa (ARANTES, 2007). É fundamental nesse processo retomar Henri Lefebvre para relembrar que um dos motivos da sobrevivência do capitalismo às crises é a produção do espaço.

O roubo, a depredação, a conversão de várias formas de direito de propriedade (comum, coletiva, do Estado) em direitos exclusivos baseados na propriedade privada, a sujeição da terra, a pilhagem e a apropriação privada de riquezas comunais atravessam a história do capital. Remonta-se nesse processo a conquista da América e do cercamento das terras comunais na Inglaterra dos séculos XVI ao XVIII passando pelo saque colonial e imperialista, pelos mecanismos tributários do sistema financeiro internacional analisado por Rosa Luxemburgo no início do século XX (GILLY e ROUX, 2009) às contínuas expropriações camponesas e indígenas durante todo o processo até as privatizações do final do século XX e XXI.

$\mathrm{Na}$ tendência histórica da acumulação originária há um significado estrutural para o capital: a resolução de suas necessidades vitais de produção, o que é particularmente

\footnotetext{
${ }^{15}$ Quanto à exportação de água, é preciso ressaltar que sua forma mais eficaz ocorrerá de maneira crescente por via indireta, por meio de alimentos e produtos industrializados que a utilizem em seu processo produtivo. São necessários 1.650 litros de água para produzir $1 \mathrm{~kg}$ de soja, 1.900 para $1 \mathrm{~kg} \mathrm{de}$ arroz, 3.500 para $1 \mathrm{~kg}$ de aves e 15 mil para $1 \mathrm{~kg}$ de carne bovina. $\mathrm{O}$ mesmo ocorre com produtos industrializados. São 10 litros de água para 1 de gasolina, 95 para $1 \mathrm{~kg}$ de aço, 324 para $1 \mathrm{~kg}$ de papel e 600 litros para $1 \mathrm{~kg}$ de cana-de-açúcar voltada para a produção de etanol (REVERS e MALVEZZI, 2009).
} 
fundamental no momento de mundialização no qual seu tempo de reposição é cada vez mais avassalador e crítico. Isto é, a existência de uma reserva de força de trabalho livre, obrigada a vender seu dispêndio de trabalho para reprodução da vida e a abertura de novas terras e territórios para a valorização do valor. Como condição complementar que possibilita essa acumulação (sempre em crise), há a violência estatal com a manutenção constitucional e jurídica da barbárie capitalista nas expropriações, num processo de acumulação na qual a destruição de relações comunitárias de vida substancia a inserção precária dos produtores autônomos nos meandros das relações salariais do mercado capitalista.

As formas contemporâneas da expropriação adquirem sua expressão abstrato-concreta nas ondas de privatização de bens e serviços públicos que tem atingido o mundo nas últimas décadas: terras, meios de comunicação e transporte, telecomunicações, bancos e serviços financeiros, sistemas de seguridade social (educação, saúde, moradia), além dos serviços e infra-estruturas de saneamento (abastecimento de água, esgotamento sanitários, coletas de resíduos sólidos e drenagem pluvial) resenhados categoricamente por Harvey (2005) e Gilly e Roux (2009). No caso da água, especialmente nos países periféricos, o capital vale-se de uma escassez objetiva, porém relativa e desigual para a produção discursiva da escassez e para fundamentar a acumulação por espoliação desses serviços e infra-estruturas. Além disso, os mananciais de água são apropriados pelo Estado para serem repassados via concessão (outorgas) de uso privado e capitalista. São então, eminentemente vantajosos na concorrência capitalista, no recebimento de tributos sociais (parte da mais valia) como renda diferencial em seus processos produtivos.

Assim, vemos que o discurso da escassez de água está longe de ser neutro ou ingênuo, sendo sim, um discurso ideologicamente construído (e concretamente violento). Nos marcos do pensamento (neo)liberal hegemônico, a água vem sendo pensada e instituída como um bem econômico mercantil a partir do conceito de escassez. Na medida em que algo é pensado (e instituído) como escasso, conforme discorrem sob diferentes preâmbulos Custódio (1994), Shiva (2006) e Porto-Gonçalves (2008), acredita-se que pode ser objeto de compra e venda, posto que ninguém compraria algo que é comum a todos por sua abundância, como algo que está disponível enquanto riqueza para todos. Sua monopolização (e instituição da propriedade privada) e sua transformação em mercadoria são marcos fundantes para se auferir lucro,

Percebemos, então, que o discurso da escassez leva, por exemplo, ao instrumento da cobrança pelo uso da água e prepara a privatização da água. Mais do que isso, o próprio discurso tornado norma e política estatal, em certa medida, irá produzir e instituir a escassez, pois como a própria palavra indica, privatizar é privar quem não é proprietário privado do 
acesso a um bem. Enfim, a privatização produz a escassez e a escassez a privatização, de modo combinado.

\subsection{Processos de privatização}

O desenvolvimento e a propriedade dos serviços de saneamento em quase todos os países do mundo estiveram historicamente sob o auspício do aparelho de Estado. No fim da década de 1980, principalmente desde a privatização dos serviços de saneamento na Inglaterra, esse mercado começou a sofrer mudanças com a entrada de capitais privados na operação dos serviços de água e esgoto (SANCHEZ, 2001). A abertura das barreiras nacionais no negócio da água colocou as empresas francesas Suez-Lyonnaise des Eaux (atualmente GDF-Suez) e Vivendi (ex-Générale des Eaux e atualmente Veolia) ${ }^{16}$ como líderes mundiais. Elas dominaram o mercado porque "aprenderam" a lidar com suas características particulares: um mercado extremamente fragmentado e dirigido pelo poder público (OLIVEIRA, 2005).

Os anos 1990 foram a década da materialização do discurso privatista. Sob o auspício do Banco Mundial e de outras instituições internacionais, a privatização da água se consolidou com a expansão das companhias privadas internacionais e a constituição do mercado global da água. A chegada das operadoras multinacionais no Brasil teve o incentivo de setores do governo federal, conforme aponta Sanchéz (2001) e Oliveira (2003; 2005). Os operadores financeiros (BNDES e CEF) eram favoráveis a programas de reestruturação que implicassem a privatização tanto das companhias estaduais de saneamento básico como das autarquias municipais. O BNDES, principalmente, atuou como um catalisador entre os agentes públicos dispostos a privatizar e os agentes privados dispostos a investir no setor de saneamento (SANCHEZ, 2001). Mas, "erroneamente", não associou esse processo com a adoção do marco regulatório do saneamento ${ }^{17}$, o que resultou, pelo menos até o ano 2000, um

\footnotetext{
${ }^{16}$ O conglomerado GDF-Suez nasceu da fusão entre a Gaz de France e a Suez em 2008 (a Suez foi resultado da fusão entre a Lyonnaise des Eaux e a Compagnie de Suez em 1997), e atualmente é uma das trinta maiores companhias de economia mista do mundo, liderando o mercado de serviços de saneamento. A GDF-Suez é a empresa líder do consórcio de construção da usina hidrelétrica de Jirau no Rio Madeira. A empresa vice-líder do mercado de água é a Vivendi, antiga Compagnie General des Eaux (CGE) fundada por Napoleão III em 1853. Sousa e Yuji (2009) relatam que em 1880 a CGE já realizava negócios fora da França, como a distribuição de água em Veneza, na Itália, obtendo nos anos posteriores contratos para os mesmos serviços em Constantinopla (Istambul, Turquia) e Porto (Portugal). Em 2000 a Vivendi abriu seu capital na Bolsa de Valores de Paris e posteriormente na Bolsa de Nova York, e em 2005 se tornou a Veolia Environnement e posteriormente o agrupamento entre serviços ambientais (Veolia Services), energia (Veolia Energy), serviços de água (Veolia Water) e transporte (Veolia Transportation).

${ }^{17} \mathrm{Em} 22$ de fevereiro de 2007 foi promulgada a Lei $\mathrm{n}^{\mathrm{o}}$ 11.445/2007 que estabelece diretrizes nacionais para o saneamento básico no Brasil. A Lei cria um marco regulatório para o saneamento definindo-o como conjunto de serviços, infra-estruturas e instalações operacionais em abastecimento de água potável, esgotamento sanitário, limpeza urbana e manejo de resíduos sólidos e drenagem e manejo das águas. A Lei não aborda diretamente a questão da titularidade dos serviços de saneamento (estados ou municípios). Porém rege que apenas o titular
} 
entrave para a privatização de empresas estaduais (ARRETCHE, 1999:34), mas não dificultou a privatização pelas autarquias municipais, para as quais a Lei de Concessões (Lei $\mathrm{n}^{\circ}$ 8.987, de 13 de fevereiro de 1995) era suficiente. Na realidade, a primeira experiência de gestão privada de serviços de saneamento no novo contexto foi em Limeira, nos primeiros meses de 1995 (OLIVEIRA, 2003), logo acompanhada por várias outras tentativas.

O aparelho do Estado, por intermédio dessas corporações, diz conseguir maior eficácia a menores preços, atrair maiores volumes de investimentos e ampliar o fornecimento de água e saneamento aos pobres que deles eram carentes. Mas a realidade foi bem diferente. $\mathrm{O}$ paradigma de mercado enxerga a escassez de água como uma crise que resulta da ausência de comércio de água. Se a água pudesse ser transportada e distribuída livremente sob a mediação do mercado, ela seria transferida para regiões de escassez com mais eficiência e qualidade. As tarifas mais elevadas levariam a conservação desse recurso.

Pressuposições de mercado são cegas aos limites sociais (e também ecológicos) impostos pela dinâmica da água e aos limites econômicos impostos pela pobreza. Invertemos esses preâmbulos, conforme observado por Mészáros (2007), absolutizando irresponsavelmente o relativo e relativizando negligentemente o absoluto. O capital opera com base nessa inversão e acirra cada vez mais esse processo. A superexploração da água para fins que não são o da equidade no acesso à água e a manutenção do ciclo abstrato da água reforçam a interpretação da água como nova raridade. A água é imprescindível, o mercado não pode substituí-la por outras mercadorias, o caminho perpassa a dominação privada e o seu monopólio.

A privatização da água adotou diferentes formas, mas apresenta uma constante: a passagem para empresas privadas do controle e da gestão de operações, convertendo em fontes de lucro a acumulação, a apropriação e o controle da água. A constante se dá de diferentes formas: a venda total das redes de abastecimento de água a empresas privadas (como no caso do Reino Unido), ou na outorga de concessão; contratos de arrendamento ou de gestão (ou formas especiais de concessão "construção-exploração-transferência", BOT em inglês). De qualquer forma, a maneira exata foi definida pelas empresas privadas. Outras variações nessa questão incluem joint ventures ou operações conjuntas com autoridades

deve prestar os serviços diretamente ou delegar a organização, regulação e/ou a fiscalização destes a outros entes da federação através de consórcios públicos e convênios de operação entre os entes federados ou delegar a prestação destes a administração do titular através de contratos. A Lei prevê ainda a criação de uma entidade reguladora que deve editar normas sobre as dimensões técnicas, econômicas e sociais de prestação de serviços. A referida lei vem enfrentando proposta na comissão de Infra-Estrutura do Senado Federal presidida pelo senador Fernando Collor (PTB-AL), com a sistemática tentativa de ampliação da participação do setor privado (FRENTE NACIONAL DE SANEAMENTO BÁSICO, 2010). 
públicas, que devem estar estruturadas de maneira que o sócio privado goze da liberdade necessária para obter lucros. Outras formas de parceria tal e qual PPP (parcerias públicoprivadas) e PSP (participação do setor privado) evitam o uso da palavra privatização, cada vez mais impopular, mas continuam se referindo aos mesmos tipos de contratação com o setor privado (SANTOS JR., 2007) como também a urbanização consorciada e as operações urbanas consorciadas (ilusão da opacidade, conforme apontado por Soja (1993). Veremos mais detalhadamente essa questão adiante).

A adoção de práticas de empresas privadas, como tem feito a Companhia de Saneamento Básico do Estado de São Paulo (SABESP), a Companhia Energética de Minas Gerais (CEMIG), a Petrobrás e a CEDAE tem sido bastante recorrente. Vejamos o caso detalhado da CEDAE no processo de privatização em 1998.

\subsubsection{A tentativa de privatização strictu sensu da CEDAE}

O modelo de privatização do saneamento básico cumpre o compromisso firmado no item 27 da carta de intenções ao Fundo Monetário Internacional (FMI) segundo explicitam Carneiro e Ávila (2007). Tal acordo demonstra como todo o processo de privatizações brasileiro foi induzido pelo Fundo e demais organizações globais (Banco Mundial, BID) que dão suporte a liberalização econômica e a conformação do mercado da água: "o governo lançou um programa de privatizações que se destina a liberar recursos fiscais e promover a eficiência na economia". "Prossegue a Carta de Intenções" de dezembro de 1991, conforme enfatiza Arantes (2002: 100):

Um programa ambicioso de privatizações que deverá render US\$ 18 bilhões nos próximos anos foi iniciado com a venda da USIMINAS - maior siderúrgica da América Latina. (...) Progresso adicional na redução da intervenção estatal na economia e na promoção de investimentos externos diretos deverá ser alcançado com mudanças institucionais que trarão investimentos privados em áreas até aqui reservadas ao setor público, como telecomunicações, mineração, transporte e comercialização de petróleo, e com um tratamento igualitário para empresas de capital nacional e estrangeiro.

Em síntese, o processo de privatização ocorreria com a compra pela União de todas as companhias estaduais de saneamento básico, seguido pelo repasse do controle para empresas privadas como demonstram Vargas (2007) e Arretche (1999). Estados e Municípios receberiam uma parte do dinheiro do repasse dos ativos financeiros com a condição de aplicálo na solução de seus problemas previdenciários. A outra parte seria para lastrear os fundos de pensão dos Estados e Municípios. O modelo corre paralelo à discussão da solução legal sobre o poder concedente e prevê acordos prévios entre Estados e Municípios. No Estado do Rio de 
Janeiro, a gestão de Marcello Alencar sancionou a Lei do Programa Estadual de Desestatização (PED) e nela incluiu a CEDAE (ASEAC, 2004; MONDEGO, 2004; VARGAS, 2007). Pretendia aquele governo, estimulado pelo governo federal, vender os ativos da companhia, isto é, venderia as ações com direito a voto que totalizava 99,99\%, sendo que o restante seria de propriedade dos empregados. Forma através da qual tornou-se uma sociedade de economia mista. A CEDAE estava avaliada, à época da tentativa de privatização, em 5 bilhões de reais. (ARRETCHE, 1999; ASEAC, 2004; MONDEGO, 1997; 2004)

A partir de agosto de 1998, o Governo do Estado preteriu a decisão ao Tribunal de Justiça do Estado, que concedera, dias antes, uma liminar à Prefeitura do Rio de Janeiro, suspendendo os efeitos da Lei 87/97 (lei que atribuiu a titularidade dos serviços de saneamento ao Estado), até o julgamento do mérito da ação contrária, movida pela prefeitura, e das Ações Diretas de Inconstitucionalidade (ADINs) que tramitavam no Supremo Tribunal Federal (STF) impetradas pelo PT, PDT, PPS e até mesmo pelo PFL. E anunciou o edital de licitação para a venda da empresa (ASEAC, 2004).

Assim, o caso da CEDAE tratou-se nas palavras de Arretche (1999) de tentativa de desestatização strictu sensu, isto é, o governo do estado simultaneamente propôs a abdicação da gestão dos serviços de uma operadora estadual e ainda abdicou que esses serviços fossem prestados por um agente público. O aparelho do Estado tomou medidas para viabilizar a venda dos ativos da empresa estadual para uma empresa privada que assumiria a concessão desses serviços.

A decisão do governo do Estado do Rio de Janeiro de privatizar a CEDAE apoiou-se na avaliação de que o nível de cobertura de serviços de água e esgotos no estado era muito baixo, o que exigiria vultosos investimentos para que se alcançasse a universalização (ARRETCHE, 1999).

A CEDAE, por sua vez, teria baixa capacidade de endividamento, paralelamente que seria impossível a sua reestruturação de modo a torná-la eficiente e rentável.

Os funcionários da companhia disporiam de excessivo grau de autonomia em relação às orientações do governo do estado, ao mesmo tempo que o gasto com pessoal seria excessivamente elevado: para uma previsão de receita da ordem de $\mathrm{R} \$ 8,5$ bilhões, cerca de $75 \%$ são gastos com pessoal, encargos e dívidas; a CEDAE paga salários muito superiores à média do mercado; e esse é o componente de despesa cuja variação é a mais elevada na evolução dos custos da companhia. Dados esses fatores, seria impossível para a CEDAE cumprir os passos necessários à estratégia de fortalecimento da companhia, daí a decisão de vendê-la.

A trajetória de desestatização compreenderia: i) criar uma agência regulatória de âmbito estadual; e ii) vender os ativos da companhia, 
concedendo a operação dos serviços a um operador ou consórcio de operadores privados (ARRETCHE, 1999:16).

As resistências contra a privatização da CEDAE foram de várias ordens: movimentos sociais, associações de moradores, partidos políticos e os técnicos da Associação de Empregados de Nível Universitário da CEDAE (ASEAC). Estes últimos elaboraram um exame técnico do conteúdo do edital. A entidade entrou na Justiça solicitando o cancelamento do leilão da empresa, marcado para o dia 9 de outubro. $O$ argumento central se explicita em sua carta programática contra a privatização referente "às condições da transferência da empresa ao setor privado" que não faziam qualquer referência, por exemplo, à necessidade de obras urgentes no sistema Guandu, ou seja, não obrigava a nova concessionária a arcar com os vultosos custos das obras de forma a impedir um colapso no sistema de abastecimento da Região Metropolitana do Rio de Janeiro. A mobilização gerou outras reações: o Tribunal de Contas do Estado (TCE) também considerou ilegal o edital e mandou cancelar o leilão (ASEAC, 2004). Depois foi a vez da Comissão de Valores Mobiliários (CVM), que suspendeu o leilão, acatando pedido do TCE.

A decisão do cancelamento foi comunicada oficialmente à população no dia 25 de setembro.

A partir da decisão do TCE, as resistências se intensificaram. Entidades como a ASEAC, diversas associações de moradores, órgãos técnicos e entidades representativas dos trabalhadores, centrais sindicais, políticos e até empresários decidiram protestar de maneira mais incisiva contra a forma com que o governo vinha tentando vender a concessionária estadual, pautando os equívocos técnicos e as ilegalidades jurídicas no edital da desestatização da companhia.

$\mathrm{Na}$ Assembléia Legislativa o projeto de lei que retirava a empresa do Programa Estadual de Desestatização (PED) foi aprovado. Mas o aparelho do Estado ignorou a decisão, no dia 19 de novembro. A Mesa Diretora da Assembléia editou um Decreto Legislativo, impedindo o leilão da CEDAE, marcado para 30 de novembro de 1998. A edição do Decreto Legislativo pela ALERJ dividiu o próprio partido do governador Marcello Alencar - o PSDB.

O Governo do estado se empenhou, entretanto, em lançar um novo Edital de privatização da CEDAE, confirmando o leilão para o dia 30 de novembro, a um mês da posse do governador eleito, Anthony Garotinho. A atitude, entre outras ilegalidades jurídicas, ignorava a liminar dada ao TCE pelo STF, suspendendo o leilão da CEDAE, além das quatro ADINs contra a lei complementar 087/97, em análise no STF. 
No TCE, a atitude do secretário de Fazenda também provocou constrangimentos entre os conselheiros, que mantiveram sua posição contra a privatização da CEDAE, sinalizando que não iriam aprovar o novo edital, feito às pressas pelo Programa Estadual de Desestatização.

O novo Edital de privatização estava estruturado em um convênio entre estado e os municípios nos arcabouços jurídicos e técnicos do realizado na Região dos Lagos (em conclusão do processo de privatização). Os municípios que não aderiram ao convênio ficaram de fora do edital, sendo eles: Niterói, São João de Meriti e Nilópolis, reduzindo o preço mínimo da venda para $\mathrm{R}$ \$ 3,84 bilhões dos quais $\mathrm{R}$ \$ 1,1 bilhão que seriam pagos à vista e o restante em 276 parcelas mensais. Do montante recebido à vista como preço mínimo, o estado ficaria com R\$ 506 milhões, a Prefeitura do Rio de Janeiro com R\$ 300 milhões e as prefeituras dos demais repartiriam entre si os R $\$ 195$ milhões. Cada município receberia 4\% do faturamento da concessionária privada no respectivo território durante a vigência da concessão a título de taxa de outorga (VARGAS, 2007).

$\mathrm{O}$ acordo foi assinado por todos os municípios, governo do estado e diretores da CEDAE em 25 de novembro.

As concessionárias internacionais que apresentaram garantias financeiras à Bolsa de Valores foram: a Companhia de Investimentos e Serviços em Saneamento formado pelas empresas francesas Suez Lyonnaise des Eaux e Vivendi; e um consórcio formado pela companhia inglesa Thames Water, a Sociedade Carioca de Energia (representante da Enron) e a PASPV (representante da empresa alemã Berlim Waters).

O leilão de venda das ações da Companhia, marcado para o dia 30 de novembro, na sede da Bolsa de Valores do Rio de Janeiro (cercada desde a véspera por grades de cerca de dois metros, por ordem do governo do Estado, para impedir manifestações da sociedade e de trabalhadores), não se realizou. E, devido, mais uma vez, a uma série de irregularidades no edital, a Justiça suspendeu novamente a operação.

Concomitantemente, a Comissão de Valores Mobiliários (CVM) também tomou a iniciativa de suspender o leilão, porque o governo do Estado não cumpriu exigências para o registro das ações da CEDAE, condição indispensável para a venda de ações de estatais de capital aberto.

No dia 2 de dezembro o governo recorreu ao Supremo Tribunal Federal e vetou a lei que excluía a CEDAE das privatizações do PED. No dia seguinte, o veto foi derrubado na Assembléia Legislativa em meio a um escândalo de compra de votos para evitar a derrubada do veto (ASEAC, 2004). Resultado: cassação de um parlamentar e abertura de Comissão 
Parlamentar de Inquérito (CPI). O governador eleito Anthony Garotinho apresentava como uma de suas plataformas de campanha o desacordo com a privatização strictu sensu. Assim estava sepultado o intento. A decisão foi publicada no Diário Oficial do dia 7 de dezembro, na forma da Lei 3.125, decretada pela ALERJ e promulgada pelo próprio chefe do Executivo estadual.

Porém, disserta Vargas (2007), a Prefeitura do Rio de Janeiro mantinha a posição de retomar da companhia estadual os serviços de água e esgoto da capital a fim de privatizá-la. Em 5 de agosto de 1999 a Prefeitura lançou um edital para concessão dos serviços de água e esgoto compreendida entre os bairros do Leme e Santa Cruz, que seria os responsáveis por $40 \%$ do faturamento da CEDAE por um prazo de 25 anos (KLEIMAN, 2005; VARGAS, 2007).

Vargas (2007:131) aponta que no edital constava que "a empresa vencedora deveria apresentar redução mínima de $10 \%$ nas tarifas, enquanto a Prefeitura receberia $8 \%$ do faturamento mensal da empresa nesta região a título de taxa de outorga". Depois de longa disputa judicial entre a Prefeitura e o Governo do estado o edital foi considerado ilegal e anulado por liminar da Justiça em 9 de setembro de 1999.

O poder judiciário considerou que a Prefeitura estava usurpando a prerrogativa do estado do Rio de Janeiro na titularidade dos serviços de água e esgoto. Entretanto, o STF julgou especificamente o caso no Rio de Janeiro, e não se pronunciou na questão da titularidade dos serviços e infra-estrutura de saneamento um todo (VARGAS, 2007).

Em suma, impediu-se a privatização strictu sensu da água e do esgoto de parte da cidade do Rio de Janeiro. A área em que se desejava a privatização é a Zona Sul, Zona Oeste valorizada (Barra da Tijuca e Jacarepaguá), além dos bairros litorâneos e periféricos da cidade (Barra de Guaratiba, Guaratiba, Sepetiba e Santa Cruz). A esquizofrenia da proposta ressalta o esquadrinhamento que se planeja o urbano e a situação crítica em que se formula um debate relevante quanto a questão das águas, além de reforço na segregação espacial e desmedida dos capitalista, aumentando as desigualdades das classes através da provisão hierarquizada de serviços e equipamentos públicos (MARQUES, 1993).

\subsection{Acesso à água sob a égide do mercado}

A cobrança pelo uso da água é considerada a "chance de ouro" na tomada de decisões (PORTO, 2009; TUNDISI e TUNDISI, 2005; NORONHA, 2003; BANCO INTERAMERICANO DE DESENVOLVIMENTO, 1998, 2003a, 2003b; 2006; VEYRET, 2007). Os investimentos de capitais apenas tangenciam a dotação de infra-estrutura para a 
equidade de tal bem. As concentrações de aplicações das finanças orientam-se na "melhoria da qualidade" de decisões, gerenciamento e ações melhor planejadas. A globalização da economia e a progressiva abertura dos mercados da água são processos cujos impactos refletem nas novas ações gerenciais na gestão pública do abastecimento de água. As grandes empresas transnacionais do setor de água implementam a lógica integradora privada (e perversa), possibilitada pelo acesso a estudos de mercado sobre o abastecimento global de água. Essas companhias têm como característica comum a política de evitar riscos em suas ações. Apresentam preferências primordiais em projetos que envolvam apenas a gestão dos sistemas integrados de água (SANCHEZ, 2001; PETRELLA, 2004).

As maiores empresas desse ramo de água são as francesas (líderes mundiais) e as inglesas (North West Water e Thames Water), com a participação cada vez maior da alemã Berlim Waters. Elas optam primordialmente pela operação, em detrimento do financiamento, da construção ou da aquisição de posições acionistas (MONDEGO, 2002).

Para tais companhias, operar (administrar o capital) é mais seguro (leia-se lucrativo) do que investir em ativos. Essas empresas praticam, também, a política de "verticalização" do setor, isto é, recorrem às suas firmas de projeto, consultoria, construção e fornecimento de equipamentos e materiais. Além disso, se houver restrições na fixação no preço de venda da água, elas aumentam a margem de lucro no preço final do produto, conforme desenvolve Sanchéz (2001). Oliveira (2002), Echevenguá (2010), Gomes (2010), Tovar (2010), Ioris (2005), Custódio (1994), Shiva (2006) entre outros, confirmam essas análises em seus estudos de caso.

No Estado do Rio de Janeiro, a CEDAE, apesar de não ser privatizada strictu sensu, estrutura uma administração voltada para o desenvolvimento de metas e ações corporativas, alinhada com um planejamento estratégico desenvolvido com a Fundação Getúlio Vargas (FGV) adotando estratégias empresariais análogas às das grandes empresas transnacionais de saneamento.

O primeiro conjunto de ações diz respeito à mimetização da marca CEDAE em Nova CEDAE: aberta para o mercado de capitais - "moderna e dinâmica", inserida no mercado global da água como mercadoria, desenvolvida pela denominada comissão de notáveis da CEDAE. Segundo as palavras de Wagner $\operatorname{Victer}^{18}$, atual presidente da CEDAE:

\footnotetext{
${ }^{18}$ Utilizaremos como elementos para elucidar essas novas estratégias em que a CEDAE está se detendo as entrevistas de Wagner Victer para o Jornal O Globo em 14/09/2007, 15/05/2009, para o Jornal O Fluminense de circulação primordialmente em Niterói e São Gonçalo de 12/04/2009 e para a Revista da Associação das Empresas de Engenharia do Rio de Janeiro. Além da análise do Jornal Valor Econômico em 26/06/2009: "Empresas públicas copiam ferramentas de gestão privada" e o projeto enviado ao Banco Inter-Americano BR-
} 
Estamos satisfeitos com a forma como o processo de desenvolvimento da marca da Nova CEDAE foi conduzido, nossa comissão de notáveis criou uma logomarca que foi apreciada de forma unânime por todos os nossos colaboradores e parceiros de negócio. A nova logomarca adquire as características que os funcionários sempre esperaram da empresa, como modernidade e dinamismo (...) pequenas ondas receberam tons de verde, em referência à responsabilidade da empresa com o meio-ambiente, e de azul, que denota a limpidez das águas distribuídas pela companhia. Escolhemos uma marca moderna, que identifica a nova gestão da CEDAE, pró-ativa e dinâmica (VICTER, 2007: 20).

\section{A marca CEDAE}

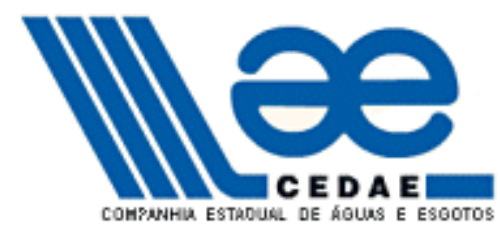

Imagem 4: $\mathrm{O}$ antigo logotipo da CEDAE

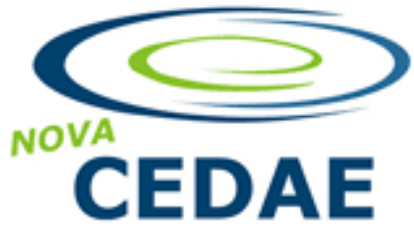

Fonte: CEDAE, 2010

Imagem 5: Novo logotipo, primeira ação da mimetização da companhia pública com os signos dos modelos das empresas privadas.

Um segundo conjunto de ações na inserção das lógicas empresariais na companhia pública diz respeito à gestão de "recursos humanos". Segundo engenheiro ${ }^{19}$ da CEDAE, esse movimento é observado em algumas organizações desde os anos 1990, por meio da criação de medidas como estabelecimento de metas, treinamentos, promoções por mérito e avaliações de desempenho dos servidores, "que funciona e faz o cara trabalhar".

Um terceiro conjunto consiste no Contrato de Assessoramento ao Processo de Reestruturação para a Distribuição Pública de Ações (IPO, sigla em inglês para Initial Public Offer) da Nova CEDAE com a Fundação Getúlio Vargas (FGV). O objetivo é transformar a Nova CEDAE numa empresa estatal "eficiente", seguindo o modelo da Petrobrás. Na mesma cerimônia de apresentação do IPO, foram empossados dois novos membros ditos "independentes" do Conselho de Administração da Nova CEDAE (o comitê de notáveis): Sidney Levy, presidente da American BankNote, e Aristides Corbelini, presidente da

T1034: Mejora de la Eficiencia Comercial y Operativa de CEDAE. Além do Comunicado de Prensa em 17/01/2007 - Cooperación Técnica del BID apoyará programa para mejorar eficiencia de Compañía de Agua y Alcantarillado del Estado de Río de Janeiro.

${ }_{19}$ Realizamos dois trabalhos de campo à CEDAE e encontramos bastante dificuldade na obtenção de dados e informações. 
Companhia Siderúrgica do Atlântico. Tal medida foi considerada "necessária e estratégica" nos marcos do planejamento estratégico da empresa para a abertura do capital na Bolsa de Valores.

O quarto conjunto de ações consiste no denominado "reequilíbrio das finanças". Segundo Wagner Victer, quando a nova administração assumiu, a CEDAE estava com um fluxo de caixa negativo da ordem de $22 \%$ ao mês em relação ao que arrecadava.

Era um prejuízo de $\mathrm{R} \$ 20$ a $\mathrm{R} \$ 30$ milhões, buraco que pretendemos fechar ainda este ano, resultado do amplo programa de redução de custos e aumento da arrecadação através do rígido combate à inadimplência, às ligações clandestinas e às perdas técnicas. Só como exemplo, este mês, não contando os dois últimos dias para fechar a arrecadação mensal, já temos em caixa $\mathrm{R} \$$ 148 milhões, R $\$ 12$ milhões a mais que o mesmo mês do ano passado. (VICTER, 2009a: 21)

A quinta ação foi a liberação de uma Linha de Financiamento não Reembolsável do BID para a "Nova CEDAE". O termo prevê, por parte do BID, a liberação de recursos, a fundo perdido, da ordem de US\$ 960 mil. Em contrapartida, a Companhia contribuirá com fundos no total de US\$ 240 mil. O objetivo do acordo é impulsionar a implantação de um novo e eficiente modelo de gestão comercial, administrativa e operativa na CEDAE. Conforme salienta Wagner Victer (2009b: 13), "Essa operação, que contará com recursos do Fundo Japonês para Serviços de Consultoria do BID, ajudará a melhorar as condições de vida da população do Rio de Janeiro mediante a elevação da qualidade dos serviços de saneamento e das condições sociais e ambientais"

O Fundo Japonês para Serviços de Consultoria foi estabelecido no Banco Interamericano de Desenvolvimento (BID) em 1995 pelo governo japonês, e proporciona recursos não reembolsáveis para serviços técnicos de preparação e implementação de projetos apoiados pelo BID em todos os setores e em todos os países membros do BID. Os projetos apoiados pelo fundo têm aproveitado a "experiência japonesa em conservação ambiental, prevenção e mitigação de desastres naturais, infra-estrutura, saúde, negócios e finanças” para implementar as parcerias.

O presidente da CEDAE assaz entusiasmado "com mais essa vitória", afirma "estar plenamente seguro com esta cooperação técnica para a modernização institucional, operacional, econômica e financeira da Companhia, que permitirá a melhora da qualidade dos serviços de saneamento em todos os municípios atendidos pela Empresa”.

Ainda segundo Victer, esta cooperação técnica demonstra claramente a mudança de postura da Nova CEDAE, "estamos sendo pró-ativos, buscando novas parcerias e financiamentos", lembra o presidente. 
O presidente do BID no Brasil garante total apoio nesta parceria, "Estamos apostando na gestão da Nova CEDAE que está passando por um momento de reestruturação administrativa e comercial. Este é o primeiro passo para a liberação de futuros investimentos", afirmou Waldemar Wirsig.

A gestão empresarial do sistema de água é compreendida como a possibilidade de recuperação do sistema: a partir da realização das estratégias empresariais e com o combate "incessante" a inadimplência e as ligações clandestinas. A mundialização financeira do capital se apresenta nesse discurso da cidade "legal", da "cidade das redes"e das infra-estruturas eficientes versus o pobre clandestino, da "cidade sem as redes". Compreendemos peremptoriamente que a financeirização da questão das águas se explicita nessas telescopagens.

\subsection{Universalização no acesso à água não significa equidade no abastecimento}

As metrópoles brasileiras apresentam um elevado índice de precariedade de infraestruturas no que tange à habitação popular, sendo marcantes as carências em serviços de saneamento $^{20}$. A redução dos investimentos na década de 1990 e os custos tarifários elevados têm contribuído para o agravamento de uma situação de precariedade no acesso aos serviços, com o conseqüente comprometimento da vida cotidiana e da saúde da população. Dados divulgados do Censo do IBGE (2010) revelam que no setor de saneamento ainda há situações de carência extrema, e enormes desigualdades sociais no que concerne o acesso ao saneamento. O governo de Luis Inácio Lula da Silva destacou a ampliação dos investimentos e das políticas de saneamento como uma de suas prioridades. Segundo análises de Britto (2009) e Lago (2009), baseadas nos dados do Censo do IBGE de 2000, existe, porém, no Brasil um déficit de abastecimento de água que se situa na faixa de mais de 10 milhões de domicílios.

Todavia, com a urbanização da sociedade nos parece que a discussão ainda está explicitamente centrada numa contradição existente, porém turva ao invés de elucidativa,

\footnotetext{
${ }^{20} \mathrm{O}$ conceito de saneamento básico no Brasil considera as redes de infra-estrutura e serviços em abastecimento de água e esgotamento sanitário. A discussão mais recente tem se estruturado a partir da proposta de saneamento ambiental, que articula além das duas dimensões supracitadas, a coleta de resíduos sólidos e a drenagem pluvial ou urbana. Apesar de compreender essas diferenças, utilizaremos na maioria das vezes somente saneamento, pois consideramos que a idéia de saneamento "ambiental" vem carregada da ideologia da primazia da sustentabilidade ambiental em detrimento da equidade das infra-estruturas de saneamento e da problemática do saneamento como questão social. Ressalta-se a importância da articulação entre os processos articulados de abastecimento de água, esgotamento sanitário, coleta de resíduos sólidos e drenagem pluvial principalmente depois da criação do Ministério das Cidades, da Lei do Saneamento Básico e do Plano Nacional de Saneamento Básico, especialmente sua articulação com o orçamento participativo.
} 
entre a preservação dos recursos hídricos ${ }^{21}$ e a universalização do sistema de água. O debate, em inúmeros momentos, nem tangencia a equidade ${ }^{22}$ no sistema de abastecimento, no nosso entendimento mais fecunda. Vejamos tais debates.

Estima-se que cerca de $1 / 4$ da população urbana dos países periféricos não tenham acesso à água potável (SOUSA, 2004). Em decorrência dos processos engendrados pelo processo de urbanização inscritos nesses países presume-se que o número dos indivíduos não abastecidos por água potável e esgotamento sanitário tende a crescer, e não a diminuir, pois há uma diferença entre qualidade da água oferecida e a quantidade matemática e aritmética de água distribuída como $o$ modelo de mensuração na discussão acerca da universalização do sistema de abastecimento de água.

Porém, segundo o Ministério das Cidades, no Brasil ainda há aproximadamente 32 milhões de pessoas vivendo sem água potável. Além disso, dos mais de 190 milhões de brasileiros, 80 milhões pagam pela água tratada, mas não podem bebê-la. A intermitência no sistema afeta cerca de $20 \%$ dos distritos estabelecidos de acordo com a Pesquisa Nacional de Saneamento Básico obrigando a população a recorrer a fontes de abastecimento nem sempre seguras, que colocam em risco a saúde e modificam estruturalmente a vida cotidiana dos moradores dessas áreas.

Sousa (2004) verificou ainda que a água oferecida à população carece de melhor controle de qualidade. Muitos dos pequenos sistemas distribuem água sem tratamento (38\% dos distritos abastecidos), um número ainda maior não adiciona flúor à água (63\% dos distritos abastecidos) e apenas $47 \%$ dos distritos abastecidos com água são objetos de

${ }^{21}$ Sob o primado do ambientalismo se produz um discurso de controle do desperdício, de orientação do progresso econômico sob princípios de qualidade total e sustentabilidade (os quais supostamente interessariam a sociedade inteira) que segundo Seabra (2003) estão naturalizando o processo social. Tanto que por esse caminho, se discute os processos como se não existissem sujeitos históricos; o devir está dado; basta administrá-lo abstendo-se de pensar a política para além dos estreitos limites que configuram as conjunturas. Nesse sentido, conforme Seabra (2003), o ambientalismo e seu conjunto de nomenclaturas e discursos se pôs como prática política que perpassa a vida social de cima para baixo. Em seu nome são formuladas políticas públicas de Estado visando alocação de investimentos públicos em todas as esferas da vida social. O ambientalismo se constitui em horizonte paradigmático. A natureza social do mundo e de suas relações é subsumida pela naturalização dos processos sociais. Assim, a água é rara nas periferias por problemas de escolha de suas moradias, acesso ilegal, desperdício ou consumo ambientalmente irresponsável (inconsciente). A CEDAE (2010) responsabiliza a ausência de água a seus moradores e não aos paradigmas capitalistas e seu conteúdo de destruição destrutiva da reprodução ampliada do capital.

${ }_{22}$ Tomamos equidade não na sua concepção usual, mas articulado as preposições marxianas de igualdade substancial, ou seja, a igualdade de fato, na qual os homens teriam as mesmas condições e os bens seriam distribuídos igualitariamente. Marx sabia que somente com a distribuição de riquezas em busca de um modo de produção baseado na coletivização dos meios de produção e com a abolição das classes, seria possível impedir a exploração dos homens pela classe dominante. Assim, a igualdade formal, aquela que é definida na Constituição, ou seja, a igualdade perante as leis, tornar-se-ia também igualdade real e sensível entre os homens. No nosso entendimento a universalização está inserida na igualdade formal: necessária, porém não emancipativa. Universalizar o sistema de abastecimento de água é tarefa essencial, porém, sendo fundamental que as classes sociais tenham acesso equânime a tal bem, realizando a dialética entre igualdade substancial e igualdade formal. 
vigilância pelas Secretarias Estaduais de Saúde conforme determina a legislação, segundo dados da PNSB de 2000.

No campo brasileiro, outros 14 milhões não têm acesso à água próxima à sua moradia como analisou (SOUSA, 2004). Sobre as costas de muitas mulheres e crianças pobres recai a sobrecarga da tarefa doméstica de buscar água nos barreiros sujos e distantes, evidenciando que o saneamento rural tem sido deixado em segundo plano, incluindo assentamentos de reforma agrária.

No município do Rio de Janeiro, em geral, a quantidade dos serviços de abastecimento de água é considerada satisfatória. Cerca de $94 \%$ dos domicílios são ligados a rede de abastecimento de água, que possui aproximadamente $9.282 \mathrm{~km}$ de extensão segundo Britto (2009) e Lago (2009). Já a Pesquisa Nacional por Amostra de Domicílios (PNAD 2001/2006) promovida pelo IBGE, indica que 99,5\% dos domicílios particulares permanentes dispunham de acesso à rede geral de abastecimento de água no ano de 2006. Esse dado pode ser considerado muito satisfatório do ponto de vista quantitativo, mas não esclarece a qualidade do serviço prestado à população, conforme discutiremos adiante inclusive sobre os critérios utilizados para a realização de tal pesquisa. $\mathrm{O}$ aumento do percentual de acesso à rede de abastecimento de água em relação ao ano de 2001 também é observado na Pesquisa Nacional de Saneamento Básico (PNSB) de 1989 e 2000, ainda que haja oscilações dos valores ao longo dos anos.

Questiona-se então: a medida qualitativa pode ser verificada através da (des)medida quantitativa? Qualidade e quantidade sendo pares dialéticos apresentam uma correspondência unívoca e dualista ou complementar e contraditória? Busca-se oferecer água de qualidade para a reprodução da vida satisfatoriamente ou a universalização é mais um instrumento para fundamentar a cidadania baseado no consumo de serviços-mercadorias? 


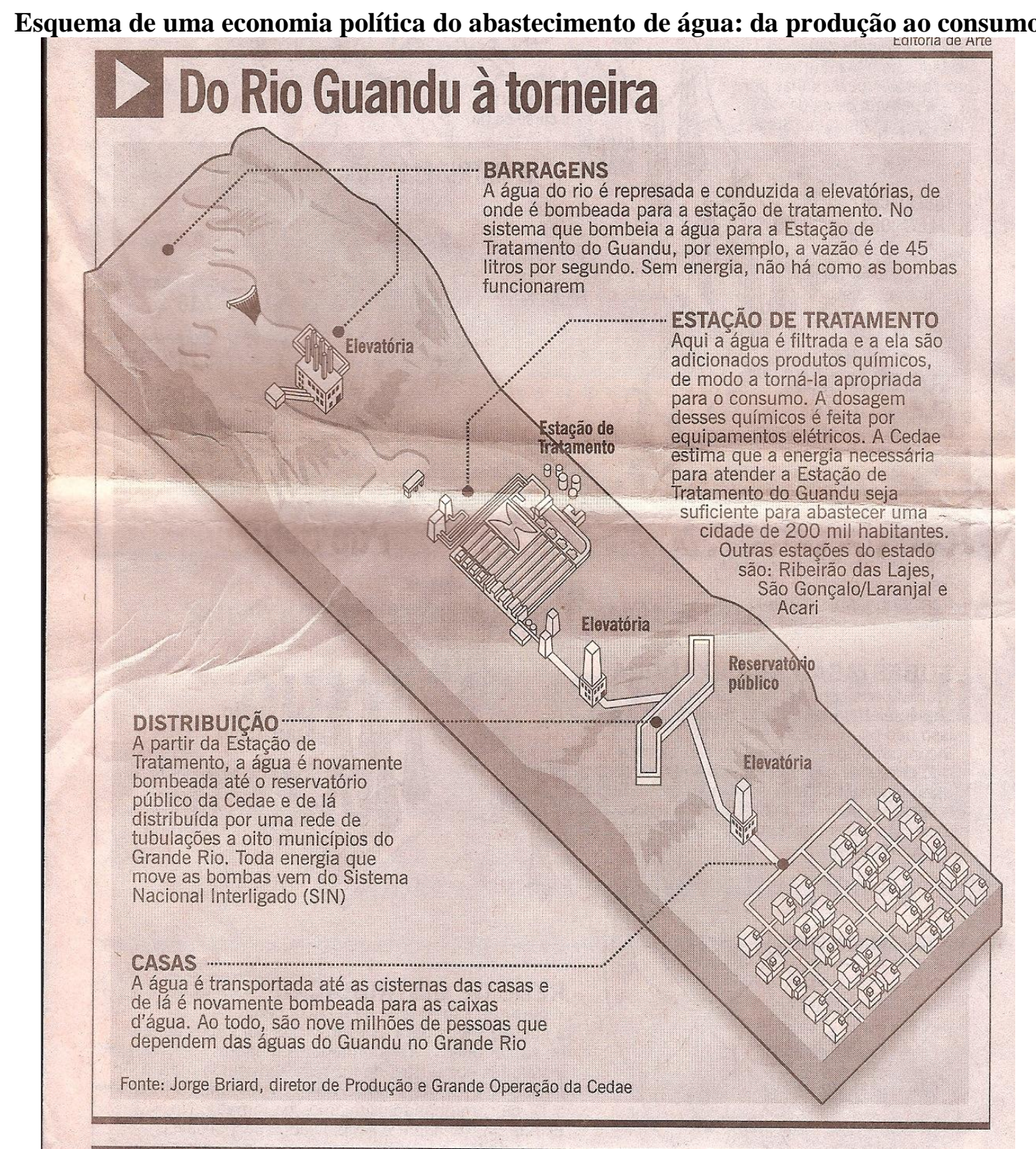

Fonte: BRAGA, Ronaldo. Falta de luz volta a atingir bairros do Rio. O Globo, 13 nov. 2009:34 Imagem 6: A rede de infra-estrutura de abastecimento de água do Sistema Guandu

$\mathrm{O}$ abastecimento da metrópole fluminense ${ }^{23}$ é realizado primordialmente pelo sistema Integrado Baixada Fluminense e Rio de Janeiro e fundamentalmente pelo Sistema Guandu (Ver Imagem 6). Este foi concebido considerando o atendimento à área do atual município do

\footnotetext{
23 "O abastecimento de água dos municípios integrantes da bacia da Baía de Guanabara é feito através de seis sistemas, sendo: Sistema Integrado do Rio de Janeiro e Baixada Fluminense, compreendendo o abastecimento dos municípios do Rio de Janeiro, Duque de Caxias, Nilópolis, Nova Iguaçu, São João de Meriti, Belford Roxo, Queimados e Japeri; Sistema Integrado de Niterói e São Gonçalo, que além de abastecer estes municípios, também atende ao distrito de Itambí e Porto das Caixas, no município de Itaboraí; e quatro sistemas isolados, que atendem aos municípios de Itaboraí, Magé, Cachoeiras de Macacu e Rio Bonito" (CEDAE, 2010).
} 
Rio de Janeiro, então Estado da Guanabara, até o ano 2000. Contudo, a fusão dos estados do Rio de Janeiro e da Guanabara ampliou a área de influência do sistema, reduzindo sensivelmente o horizonte de auto-suficiência de abastecimento projetado (CEDAE, 2010).

Contudo, como consequiência de todas as obras terem sido realizadas em caráter de emergência, e sempre com alcances inferiores à demanda da época, as expansões de rede foram sempre, inevitavelmente, superiores à capacidade de adução do sistema (BRITTO, 2009; CEDAE, 2010).

A ausência de setorização do sistema de distribuição implica em um controle operacional que o aparelho do Estado considera deficiente, o que, aliado ao baixo índice de medição (sinônimo de pagamento de água), acarreta um elevado nível de perdas (isto é, desperdício de água).

Britto (2009) argumenta que a necessidade de redução do déficit de produção de água tratada, que afeta principalmente as regiões da Baixada Fluminense e Zona Oeste da cidade do Rio de Janeiro, fez com que a CEDAE iniciasse a execução das obras de ampliação do complexo de produção do Guandu, de forma a viabilizar a melhoria do abastecimento de água da Baixada Fluminense (acréscimo de $4 \mathrm{~m}^{3} / \mathrm{s}$ ) e da cidade do Rio de Janeiro $\left(3 \mathrm{~m}^{3} / \mathrm{s}\right.$ ), principalmente da Zona Oeste com $2 \mathrm{~m}^{3} / \mathrm{s}$. Todavia, tal obra permanece inconclusa.

\begin{tabular}{|c|c|c|c|c|}
\hline \multirow{2}{*}{$\begin{array}{c}\text { Área de } \\
\text { Planejomerto }\end{array}$} & \multirow[b]{2}{*}{ Ano } & \multicolumn{3}{|c|}{ PercentualAtendido (fit) } \\
\hline & & Rede geral & $\begin{array}{l}\text { Outras forms } \\
\text { (1) }\end{array}$ & 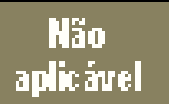 \\
\hline \multirow{2}{*}{ Município } & 1991 & 96,40 & 2,60 & 1,00 \\
\hline & 2000 & 96,70 & 2,40 & 0,90 \\
\hline \multirow{2}{*}{ AP1 } & 1991 & 95,20 & 1,50 & 3,30 \\
\hline & 2000 & 96,10 & 0,90 & 300 \\
\hline \multirow{2}{*}{ AP2 } & 1991 & 96,50 & 2,30 & 120 \\
\hline & 2000 & 97,90 & 1,40 & 0,70 \\
\hline \multirow{2}{*}{ AP3 } & 1991 & 97,80 & 1,70 & 0,50 \\
\hline & 2000 & 97,90 & 1,60 & 0,60 \\
\hline \multirow{2}{*}{ AP4 } & 1991 & 91,40 & 6,50 & 2,10 \\
\hline & 2000 & 93,40 & 5,50 & 1,10 \\
\hline \multirow{2}{*}{ AP5 } & 1991 & 96,20 & 3,20 & 0,60 \\
\hline & 2000 & 95,80 & 3,30 & 0,90 \\
\hline
\end{tabular}

Fonte: Proposta de Revisão do Plano Diretor (2009)

Tabela 1: Percentual de domicílios ligados a rede geral de abastecimento de água 
Porém, os percentuais mais significativos de domicílios sem abastecimento adequado encontram-se justamente na Zona Oeste do município e nas favelas.

A Zona Oeste do Rio de Janeiro é enquadrada nas áreas de planejamento 4 e 5 (Ver Mapa 1). Sendo que a AP-5 é constituída por áreas periféricas distantes que serão foco desse trabalho, vetor de expansão do proletariado empobrecido da cidade. A AP-4 é vetor de expansão da classe média alta e da classe alta do município, porém ressalva-se a presença e expansão de favelas também nessa área.

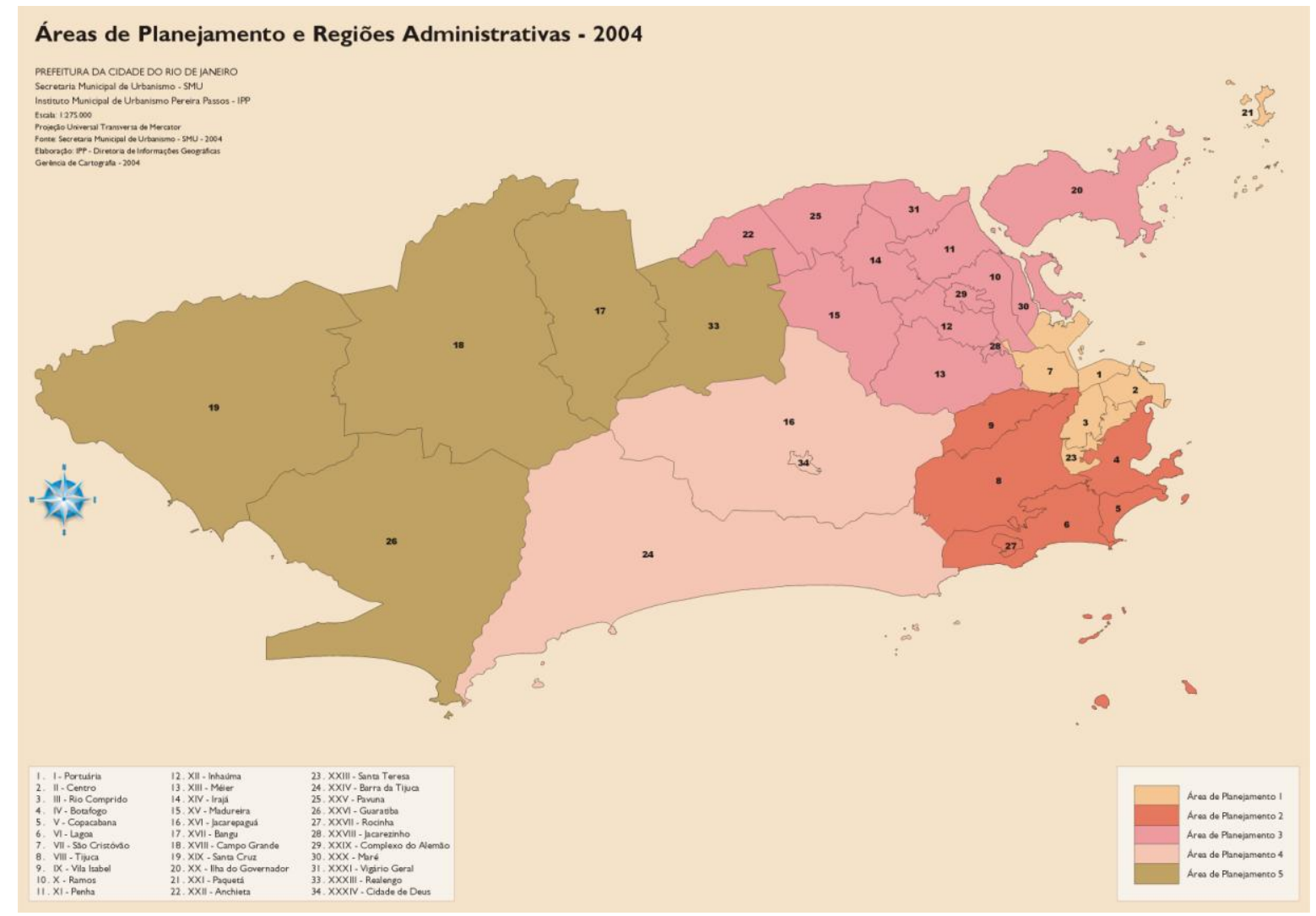

Fonte: Plano Diretor, 2010

Mapa 1: Áreas de Planejamento e Regiões Administrativas da Cidade do Rio de Janeiro - 2004

Nas favelas, verificamos que a partir das décadas de 1970 e 1980 foram desenvolvidos diversos programas para levar os serviços de saneamento. Embora o abastecimento de água tenha melhorado, os resultados alcançados ficaram muito distantes de uma universalização de atendimento, quiçá da equidade no acesso.

Este passou a apresentar uma grande heterogeneidade. Algumas favelas têm o serviço, outras não; em muitas a distribuição de água é intermitente, em outras a pressão e volume são insuficientes; em outras há a ausência absoluta ou a qualidade é insatisfatória. 
Os dados inúmeras vezes escamoteiam a realidade: a questão do racionamento de água é atribuída na maior parte dos casos a problemas na reservação. Por exemplo, o sistema de abastecimento de água nas favelas da periferia na Zona Oeste, assim como na Baixada Fluminense, funciona de forma precária, não existindo uma separação física entre adução e distribuição (setorização), o que significa a ausência de reservatórios e de uma setorização do sistema de distribuição. A negligência em tais espaços da cidade pressupõe a captação de água diretamente das linhas de adução, sendo estas ligações consideradas pelo poder público como "clandestinas", "gatos", perdas no sistema de distribuição.

Há ainda o problema da falta de água e a distribuição irregular em diversos pontos, e ainda a pressão excessiva em determinados pontos de captação. As sucessivas ampliações da produção e da adução de águas, realizadas no sistema Guandu e materializadas em mapas e tabelas de ampliação do sistema de água, homogeinizam favelas, bairros, áreas de planejamento. As ampliações são realizadas sem a construção de reservatórios e sem a definição de suas áreas de influência (MARQUES, 2000; KLEIMAN, 2002; BRITTO, 2009), levando a um sistema com alto grau de incertezas, que funciona precariamente, baseado em permanentes manobras de água (KLEIMAN, 2007) realizadas de forma aleatória e muitas vezes clientelistas. E permanece a manutenção da raridade da água e a opacidade com que se enxergam determinadas áreas da cidade.

Em suma, há um conjunto complexo de questões políticas acerca da "engenharia das obras" de saneamento. O saneamento não é somente uma problemática tecnocrática ou ambienta, mas fundamentalmente uma questão social.

\subsection{As águas da crise}

O fato é que a água não é apenas um bem essencial para a natureza e para a natureza humana. A água, quando subordinada aos ditames do capital, é fonte de lucro e de riqueza para as corporações interessadas em sua privatização. Entretanto, essas corporações têm que se fazer presentes no território de onde a água não pode ser abstraída, já que ela atravessa toda a sociedade e seus lugares (PORTO-GONÇALVES, 2006). Como conseqüência, há resistências em todo lugar onde se tenta o monopólio capitalista da água. São expostas as águas da crise capitalista, que vêm se esmerando na conformação de novas formas de regulação com uma nova institucionalidade cujo eixo central está na tentativa de privatização dessa riqueza e na sua mercantilização. $O$ tema central passa a ser se a água é um meio para a reprodução da vida inscrita nos imbricamentos dialéticos entre sociedade e natureza ou um 
bem, uma propriedade privada capitalista ou um recurso para a reprodução econômica. Algumas respostas podem ser observadas no retorno às discussões de Marx.

$\mathrm{O}$ enfoque marxista sobre tais questões é fulcral. O capital tem uma potência a se expandir e a dominar outras formas de sociabilidade, mas também uma determinação negativa, autodestrutiva, que impede a dominação completa e definitiva. É nas fissuras que ele cria para si mesmo que a transformação pode ocorrer. A reprodução do capital porta então, a negatividade crítica da resistência, o capitalismo avança e se expande contendo no seu movimento contraditório, expansionista e desmedido, as lutas anti-capitalistas que nascem de sua negação e portam a possível revolução e superação do modo de produção. A dimensão materialista histórica dessa relação é a luta de classes.

As resistências materializam-se, por exemplo, na Guerra da Água em Cochabamba (Bolívia) em abril de 2000 e no desafio permanente da gestão comunitária das águas; nas lutas contra a privatização na Ucrânia onde os movimentos de mulheres apresentam papel central; na luta em Savelugu (Gana) e na Argentina pela gestão cooperativa dos sistemas de abastecimento; na Índia os embates são contra as normatizações da técnica (a construção de poços artesianos tem aumentado os índices de desertificação, pois sedentariza os povos que no deslocamento realizam suas vidas) que desqualifica os saberes dos povos nômades sobre as águas, como uma outra racionalidade que não é considerada; e no Brasil na luta do Movimento de Atingidos por Barragens (MAB) contra o modelo hidrelétrico, pois quase não existem mais rios sem planos ou projetos de pequenas ou grandes barragens. $\mathrm{O}$ modelo francês dos comitês de bacias, utilizado no Brasil e criticado pelo MAB, está longe de apresentar soluções para o abastecimento e gestão das águas para as classes sociais mais pobres. As barragens que já foram construídas atingiram mais de 1 milhão de pessoas, o que substancia suas frentes de luta: "água e energia não são mercadorias", "nossa terra, nosso rio, não se vende; nossa terra, nosso rio, se defende" e "águas para a vida e não para a morte".

Percebemos, então, que em diversas partes do mundo há exemplos categóricos desses meandros de ação contra imposições verticais daqueles que governam as águas: aparelhos e burocracias de Estado, empresas transnacionais de várias ordens com seus nichos de mercado (engarrafamento - envasamento - de água, compra de mananciais, prestadoras de serviço de abastecimento de água, construtoras de grandes projetos hidrelétricos, etc.), monopolização de terras comunais e ainda os órgãos multilaterais.

Karl Marx, no movimento de sua obra, interpreta a acumulação capitalista através das suas contradições sociais, ao contrário da concepção clássica liberal, baseada restritamente nas limitações naturais. De acordo com as análises de Marx, a continuidade do modo de 
produção capitalista, orientada prioritariamente pelo sobrelucro (maximização dos lucros), conduz tendencialmente a uma crescente exploração, alienação e expropriação da força de trabalho, por um lado, e por outro, à deteriorização da base de produção econômica, da fonte da riqueza, ou seja, da natureza (MARX, 2007, QUAINI, 2002; FOSTER, 2005; CARCANHOLO, 1996; SALVIATTI, 2010).

O surgimento do capitalismo consubstancia-se em um sistema econômico baseado na produção de mercadorias. O capitalismo combina, num único conceito, as duas formas do valor (o duplo caráter da mercadoria), com o valor de troca orientando o significado do valor de uso.

O objetivo da reprodução ampliada do capital tem como pressupostos:

1) “... trabalho livre e troca de trabalho livre por dinheiro, com o objetivo de reproduzir o dinheiro e valorizá-lo; de o trabalho ser consumido pelo dinheiro - não como valor de uso para o desfrute, mas como valor de uso para o dinheiro.

2) “... a separação do trabalho livre das condições objetivas de sua efetivação - dos meios e do material do trabalho. Isto significa, acima de tudo, que o trabalhador deve ser separado da terra enquanto seu laboratório natural significa a dissolução tanto da pequena propriedade livre como da propriedade comunal da terra assentada sobre a comuna oriental" (MARX, 2006:65).

A natureza separada do processo de humanização do homem torna-se não apenas meio de vida, mas meio de produção, tendo em vista sua transformação em recurso capitalista e propriedade privada, contribuindo nos circuitos de valorização do valor e na renda diferencial da terra, mudando seu caráter de uma relação de intercâmbio homem-natureza para o de uma relação de troca mercantil, numa orientação que descola a relação metabólica do processo de humanização do homem para ligá-la ao processo de produção de mercadorias.

Os paradigmas e discursos sobre a crise das águas são coetâneos da crise estrutural do capital e de sua destruição destrutiva, mais acentuadamente verificada a partir da década de 1970. Essa crise expande-se no vácuo das atuais políticas de doutrina neoliberal, bem como as novas estratégias empresariais chamadas flexíveis (que flexibilizam, na verdade, a exploração do trabalho), que juntas vieram se difundindo a partir daquela década e nas décadas posteriores, como respostas dos gestores da ordem do capital no sentido de reestruturação E rearranjo do capitalismo em crise.

Uma das considerações teóricas do conceito de crise sob o prisma marxista ressalta que a contradição imanente à acumulação capitalista é que o capital tende a produzir uma quantidade ilimitada de mercadorias (tanto em termos de valor como em termo de valor de 
uso) ao mesmo tempo em que tende a reduzir a capacidade de consumo no sistema, possibilitando uma tendência de superprodução e sobrelucro.

Isto porque impelidos a assim fazer pela concorrência que existe entre capitais, os capitalistas tendem a reduzir o tempo de trabalho necessário para a produção de mercadorias, aumentando a composição orgânica do capital, o que reduz relativamente tanto a necessidade de consumo da sociedade, como impõe aos mesmos capitalistas, devido à produtividade decorrente das novas tecnologias economizadoras de força de trabalho, a necessidade de lançar uma maior quantidade de mercadorias na circulação do mercado para realizar um mesmo montante de valor (CARCANHOLO, 1996). A natureza, então, sofre uma pilhagem constante de suas riquezas naturais e é levada ao limite da exaustão (as crises ecológicas são a aparência desse processo), e os trabalhadores são potencialmente levados aos limites da exploração. Os limites não são estabelecidos pela natureza, nem pelos trabalhadores explorados no processo produtivo: o capital impõe os limites das explorações e das pilhagens, tendo como objetivo a reprodução ampliada de si mesmo, em expansão permanente.

Assim, de uma perspectiva marxista, as crises do modo de produção capitalista constituem expressões inevitáveis de contradições básicas ao funcionamento objetivo desse modo de produção, particularmente no momento da mundialização do capital (CHESNAIS, 1998) e da servidão financeira (PAULANI, 2008). A crise é a expressão do resultado do desenvolvimento das contradições inerentes ao modo de produção capitalista. É, também, o momento de explicitação dos contrários é a negatividade do capital, que se apresenta na aparência como positividade. A unidade entre estes opostos só é reafirmada através da crise. As crises, todavia, não atenuam as contradições e muito menos as suprimem.

Ao mesmo tempo em que rompe a unidade, a crise corresponde justamente a um ajuste entre os elementos em contradição que possibilitam esta acumulação (CARCANHOLO, 1996): produção e consumo, capital e trabalho, propriedade e apropriação. O capital tende a socializar as perdas e prejuízos e se apropriar privadamente dos benefícios econômicos e financeiros, primordialmente sob o auspício do Estado e sua transferência de renda, como observado na crise de 2008. Esse ajuste econômico e social promove ajustes espaciais (HARVEY, 2005), sendo especialmente avassalador para as classes sociais nas quais os capitalistas necessitam realizar "novos" processos de acumulação e produção de capital. Mas, na recorrência deste processo, ocorrem conflitos latentes resolvidos apenas com ajustes políticos, econômicos, sociais e espaciais, como por exemplo, na participação de empresas transnacionais de modo cada vez mais intenso e explícito no abastecimento e acesso a água em diferentes partes do mundo. Isto é, na abertura de áreas no mercado para a participação, 
parceria e privatização do sistema. O capital não cessa de acumular capital numa desmedida que se expressa, dentre outras aparências, na crise ecológica e na crise do abastecimento, fornecimento e apropriação das águas.

Petrella (2004:16) argumenta que nesse momento estamos diante da "petrolinização da água" como uma tendência que se afirma, sobretudo a partir das décadas de 1970 e 1980. Podemos interpretar tais discussões como a entrada da água no mesmo circuito de valorização mercantil que o petróleo, o que significa efetivamente um aumento do custo para utilização dos materiais utilizados nos processos produtivos, disso decorrendo o fato de no debate internacional a água aparecer sob a forma de "recurso hídrico". ${ }^{24}$ Em verdade, trata-se de uma conseqüência da lei da tendência da queda da taxa de lucro.

Hirshleifer et.al. (1960:8) apud Shiva (2006) afirmam que

Não queremos negar que, como mercadoria, a água tem suas características próprias, por exemplo, seu funcionamento é suprido pela natureza, em parte na forma de estoque e em parte como um fluxo, e ela está disponível sem custo algum em algumas localidades, mas é bem cara para transportar para outras localidades. Qualquer motivo que citemos, no entanto, quando analisado, faz com que a alegada importância única da água desapareça.

Argumentos abstratos e de uma lógica idealista e simplista - como o supracitado sobre a questão não entendem o ponto mais importante de quando se maneja a escassez da água, isto é: quando a água desaparece, não há alternativas. Para as mulheres dos países periféricos significa caminhar por longas distâncias em busca de latas d'água, para os camponeses significa fome e miséria já que a seca destrói suas colheitas, para crianças

\footnotetext{
${ }^{24}$ Tomamos a título de exemplificação a argumentação de Luiz Corrêa Noronha, engenheiro sanitarista e consultor da Agência Nacional de Águas e do Banco Mundial de que "a água é o elemento natural descomprometido com qualquer uso, ou seja, é o gênero, enquanto que o recurso hídrico é a água como bem econômico passível de utilização para fins específicos (...). Água precisa ter legislação e gestão. Por sua vez, os serviços de saneamento básico, usuários de água, tanto para abastecimento público como para disposição de dejetos, configuram-se como serviços públicos, os quais não necessitam ser prestados apenas pelo setor público, mas sim controlados pelo mesmo e regulados de forma adequada" (...) 'Querem privatizar a nossa água'! Ora, a sociedade brasileira já decidiu, em sua Constituição e na Lei de Recursos Hídricos, que a água é um bem natural de domínio público. O que algumas pessoas defendem (...) é que a prestação dos serviços públicos de saneamento básico possa contar com maior participação da iniciativa privada. Negar essa possibilidade seria o mesmo que não admitir a existência de escolas, universidades, hospitais, empresas de segurança e vigilância, empresas de transporte coletivo privados. A prestação dos serviços públicos de educação básica, saúde, segurança ou transporte coletivo urbano também são serviços públicos, em muitos casos prestados de forma eficiente pela iniciativa privada. Por que os serviços públicos de saneamento básico deveriam ser diferentes?" (NORONHA, 2003). O Estado capitalista é apresentado pelo autor como o administrador (o gerente ou gestor) do sistema, num posicionamento explicitamente neoclássico colocando o mercado como o "melhor" regulador e os paradigmas de eficácia fundamentados na doutrina neoliberal como "solução". A desmedida da exploração e reprodução ampliada capitalista passam ao largo dessa análise torpe. Todavia o artigo "Acesso à Água nas Favelas do Mundo em Desenvolvimento" (DAGDEVIREN e ROBERTSON, 2009), divulgado pelo PNUD em parceria com o governo brasileiro, mostra que as condições dos serviços de água e de saneamento não melhoraram com a saída do setor público e a privatização para a iniciativa privada, pois verificou-se que nas áreas pobres e de baixa renda houve a diminuição dos investimentos que não foram preenchidos pelo setor privado.
} 
significa desidratação e morte (SHIVA, 2006). A água é fluxo, movimento por ela e com ela flui a vida (PORTO-GONÇALVES, 2006; 2008) e a dificuldade em seu acesso afeta as classes sociais mais pauperizadas na cidade e camponeses e povos originários no campo.

A economia afirma o sentido do mundo na produção, a natureza é coisificada, desnaturalizada de sua forma concreta e convertida em matéria prima do processo econômico. Os recursos naturais se tornam objetos para a exploração no processo de reprodução ampliada do capital. A água deixa de ser um processo de trabalho para ser codificada nos termos do capital. Descolam-se, deslocam-se e ocultam-se as conexões da relação metabólica entre sociedade-natureza e vida cotidiana da água para mimetizá-la em recurso hídrico.

A relação entre o homem e a natureza e entre os próprios homens é o fundamento da prática sócio-espacial. Natureza, natureza natural e natureza produzida são essencialmente sociais. A exteriorização da natureza (num processo de apropriação, alienação e estranhamento) em relação ao homem é um processo histórico contraditório à humanização da natureza e à naturalização do homem (DAMIANI, 2008).

A universalização da mercadoria, isto é, a transformação de todo o (im)possível em mercadoria (homens e natureza em suas variadas formas) só é necessária porque a produção de mercadorias é o motor da produção da mais-valia, e a realização desta (sua compra-venda) no lucro é o motor da acumulação, o lucro que será reinjetado em novo ciclo de produção de mercadorias para a produção de mais mais-valia. Sobre esta base o capitalismo se expande em escala planetária (MOREIRA, 2008; 2009). 


\section{A Ilusão da Transparência e a Ilusão da Opacidade na interpretação da questão social do abastecimento de água}

O que nos inquieta, para iniciar os debates nesse capítulo, é a contundente constatação de Soja (1993) que tomamos como questão, refazendo-a: como é possível fazer com que o espaço esconda de nós as conseqüências das relações de poder e disciplina que se inscrevem em interpretações míopes das espacialidades? Como através da espacialidade concreta da vida social se projeta a produção e reprodução em idealismo e pensamento reflexivo imaterial? Como as estratégias do aparelho de Estado, de parte da academia e da mídia agem reforçando tais perspectivas? Por que tais questões são fulcrais para compreender o abastecimento de água nas favelas, conjuntos habitacionais e loteamentos na periferia distante da cidade do Rio de Janeiro, isto é, na Zona Oeste de tal município?

Comecemos refletindo acerca das favelas e dos loteamentos (irregulares ou clandestinos) no mundo contemporâneo. A questão habitacional é um dos pilares centrais da crise urbana. Todavia, são mobilizados para o debate conceitos e enfoques que mais iludem que esclarecem as discussões (SOJA, 2003), tais como: desordem, cidade partida, ilegalidade e marginalidade de tais espaços, e não da produção do espaço da periferia. Essas premissas têm sido motivadas pelas proporções que esses fragmentos do espaço passaram a apresentar na metrópole, como representações da pobreza, mobilizando a ação e intervenção do aparelho do Estado, o interesse de intelectuais e a atenção da mídia. Consideramos, todavia, que devese observar as leituras opacas e transparentes sobre esses espaços realizadas por esses sujeitos sociais, esclarecendo-as.

Assim concordamos com Soja (1993) que a ilusão da transparência desmaterializa o espaço em ideação e representação puras, num modo de pensar intuitivo que também nos impede de ver a construção social das geografias afetivas e a concretização das relações sociais inseridas na espacialidade, numa interpretação do espaço como uma abstração concreta num hieróglifo social semelhante à conceituação marxista da forma mercadoria (SOJA, 2003; LEFEBVRE, 1978; 2008a; 2008b).

O tecido urbano se prolifera, estende-se e corrói os resíduos de vida agrária, ocorrem implosões-explosões das áreas centrais e realiza-se a expansão periférica e a consolidação da situação permanentemente crítica da sociedade: espraiam-se loteamentos, conjuntos habitacionais e favelas para as periferias distantes das cidades. Neste capítulo, então, propomos uma discussão que enfoca os movimentos das classes sociais no espaço urbano, e, 
ao mesmo tempo, a consolidação do processo de segregação entre as classes sociais balizados na leitura social da questão das águas na Zona Oeste do município do Rio de Janeiro. Propomos uma reflexão sobre os efeitos do processo de urbanização do tecido urbano na periferia da cidade do Rio de Janeiro, para tentar responder a questões primazes desse capítulo.

\subsection{A ilusão da transparência da Zona Oeste ${ }^{25}$ da cidade do Rio de Janeiro}

Nosso foco de análise é a Região Administrativa de Santa Cruz (XIX RA) que está localizada no extremo oeste do Município do Rio de Janeiro e é composta pelos bairros de Paciência, Santa Cruz e Sepetiba. A RA ocupa uma área total de 168,04 km² assim distribuída: Paciência, 27,41 km²; Santa Cruz, 125,04 km² e Sepetiba, 11,62 km². Segundo o IBGE a população total da RA era, em 2000, de 311.289 habitantes, distribuída da seguinte forma: Paciência, 83.561 habitantes; Santa Cruz, 191.836 habitantes; e Sepetiba 35.892 habitantes. Tal área da cidade do Rio de Janeiro é considerada pelo aparelho de Estado da Prefeitura como uma das áreas com maior índice de irregularidade no parcelamento e uso do solo no Município. A região possui no seu território 114 loteamentos (46 irregulares e 68 clandestinos) e 33 favelas (VERÍSSIMO, 2004). Este conjunto de assentamentos abriga uma população estimada em cerca de 140.000 habitantes ${ }^{26}$ (IBGE, 2000), o que corresponde a aproximadamente $45 \%$ do total dos moradores da região administrativa de Santa Cruz (VERÍSSIMO, 2004:1-2). Outra característica é a denominada "irregularidade fundiária" que

\footnotetext{
${ }^{25}$ Façamos uma diferenciação: a Zona Oeste (ver a área em rosa do Mapa 2) representa mais da metade do município do Rio de Janeiro e há uma enorme disparidade econômica e social entre os seus bairros englobados. Esse conceito insere-se na esfera do planejamento territorial, ocasionando dificuldade de compreensão da realidade dinâmica e crítica do contemporâneo, pois engloba em seu arsenal bairros distintos. Partimos da compreensão de Vieira (2004) que argumenta que Barra da Tijuca, Recreio dos Bandeirantes, Vargem Grande, Camorim e Jacarepaguá foram produzidos sob diferentes espectros sob o reflexo de zonas já consolidadas da cidade. Deste modo, Barra da Tijuca e Recreio dos Bandeirantes fundiram-se ao simbolismo da Zona Sul, e Jacarepaguá, à Zona Norte. Nosso intuito quando nos referirmos a Zona Oeste é o de conceituar primordialmente os bairros que se situam fora da lógica supracitada, ou seja, os bairros que são encaixados na definição "simbólica" do que significa a Zona Oeste. Nossa análise fundamental, porém, refere-se a periferia do extremo oeste, isto é, os bairros de Santa Cruz, Paciência e Sepetiba; e as favelas da periferia do extremo oeste, as quais se encontram entre os bairros de Santa Cruz e Paciência.

${ }_{26}$ Observamos as mesmas problemáticas de pesquisa que Rizek (2009) encontrou ao analisar a periferia da cidade de São Paulo (no caso da autora a Cidade Tiradentes). Nos trabalhos de campo que realizamos na periferia do Rio de Janeiro, os entrevistados apontavam uma população muito maior do que aquela apresentada pelo aparelho do Estado. Concordamos com Rizek (2009) de que a impossibilidade de conhecer os dados mais elementares tem a ver com a forte opacidade que cerca a (ilusão) da transparência do espaço e a opacidade nas análises sobre a periferia.
} 
remonta a aspectos históricos da área (VERISSIMO, 2004: 2). Além do fato de que a Zona Oeste apresenta uma das mais baixas rendas da cidade ${ }^{27}$.

Lago (2003:2) aponta que o cerne do debate acerca da moradia do proletariado urbano está inserido na discussão da "ilegalidade no seu acesso a moradia". Esse aspecto apresenta um ponto de interpretação dessa questão, e um campo cego de análise: “é o reducionismo do próprio universo em questão, tendo em vista a relação, quase inexorável, da ilegalidade com a pobreza urbana. A ilegalidade das camadas médias e altas não tem sido problematizada". Maricato (2007) também expõe tais perspectivas em seus trabalhos. Ressalta-se que ao longo das décadas de 1990 e 2000 é que a exclusão social e o debate acerca da ilegalidade urbana foram "territorializadas" nas favelas, minimizando-se na cena acadêmica, política e na mídia outros espaços representativos desse universo (LAGO, 2003; VALLADARES, 2006), como as periferias e os loteamentos clandestinos e irregulares que as conformam, os quais, nas décadas de 1970 e 1980, apareciam como a expressão maior da problemática urbana.

\footnotetext{
${ }^{27}$ A renda per capita da população do bairro de Santa Cruz é R\$ 206,23, em contraste com a renda do bairro da Gávea, primeira no ranking, de $\mathrm{R} \$ 2.139,56$. A renda domiciliar per capita média dos $20 \%$ mais pobres de Santa Cruz é de R\$27,62. (IBGE - Censo Demográfico, 2000).
} 


\section{Representação cartográfica do zoneamento simbólico da cidade do Rio de Janeiro}

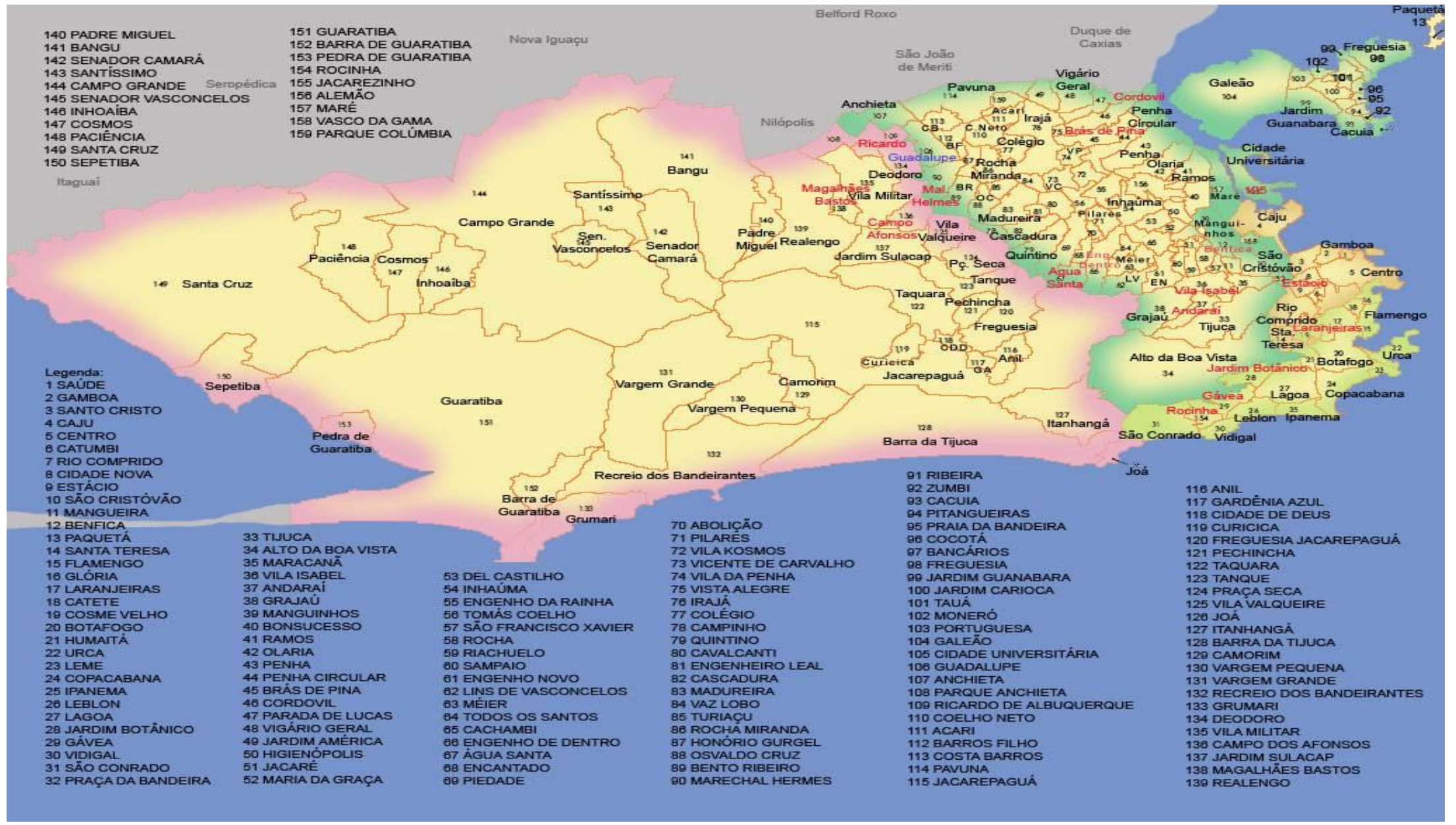

Fonte: PAIVA, 2008

Mapa 2: Mapa do zoneamento da cidade do Rio de Janeiro. 
Partimos de alguns pressupostos: a análise das classes sociais ${ }^{28}$ inseridas na produção do espaço e a produção do espaço como um processo sócio-espacial na cidade, imbuído, contemporaneamente, do urbano como mercadoria, submisso à troca e à especulação, que produz um constante movimento de atração e de repulsão da população do centro para a periferia. Esse processo substancia uma determinada morfologia da cidade, que é definida e valorizada de maneira diferencial. Esse processo, que se caracteriza pelas necessidades de expansão do capital, produz um espaço urbano transformando os seus referenciais e os comportamentos em relação à cidade (CARLOS, 1996:58).

O processo de crescimento da periferia no município do Rio de Janeiro, especialmente retratando a Zona Oeste pós-década de 1990, se expande exponencialmente no aumento do número de favelas. Aliás, considera-se categoricamente a periferização como um termo que designa uma forma específica de estruturação do espaço urbano, que tem como características a segregação e condições precárias de moradia e acesso a infra-estrutura urbana (BONDUKI e ROLNIK, 1979). Na ausência de oferta de habitações salubres surgem soluções precárias como as favelas, os loteamentos e suas casas auto-construídas na periferia (OLIVEIRA, 1982; MARICATO, 2007; LAGO, 2003).

Em cidades como o Rio de Janeiro, Salvador e Recife, as ocupações em favelas nas áreas centrais marcaram, notadamente, as áreas de maior influência da reciprocidade e da inserção marginal (MARTINS, 1997) no espaço urbano, ou como Kowarick (1979) aponta da espoliação urbana, definindo uma configuração socioespacial, caracterizada pela proximidade física entre ricos e pobres. Ao mesmo tempo, as periferias expandiam-se, através do mercado de lotes (LAGO, 1990), como lócus privilegiado da precariedade e da sobrevivência. Essa combinação de modos de integração ao urbano numa sociedade crescentemente desigual resultou num padrão de estruturação espacial segregador e reprodutor, na esfera do consumo e do acesso à infra-estrutura urbana das desigualdades de classes (LAGO, 2003).

A literatura das décadas de 1970 e 1980 destacou a relação entre centro-periferia, marcado pela distância física e social entre as classes (VALLADARES, 1980; SANTOS, 1981; OLIVEIRA, 1982; LAGO, 2003, 2009; LAGO e RIBEIRO, 2001; RIBEIRO e CARDOSO, 1994).

\footnotetext{
${ }^{28}$ Podem-se verificar em Marx dois níveis de argumentação acerca das classes sociais em âmbitos políticos e econômicos: quando as condições econômicas e o modo de vida de uma classe se opõem aos interesses e à materialidade do cotidiano de outras classes, dá-se a classe no sentido econômico; e quando se estabelece alguma ligação local, ou quando a similitude de interesses leva a algum tipo de comunidade, associação ou organização política, dá-se a classe no sentido político, ou melhor, a classe propriamente dita. Tomam-se como norte nas interpretaçães os aspectos relacionados aos meios de produção e a reprodução ampliada do capital.
} 
Marca-se nesse momento a reafirmação da favela ${ }^{29}$ como representação da ilegalidade e o loteamento como a irregularidade no acesso ao urbano, sendo que o marco de referência é a propriedade privada da terra. A espacialidade das classes sociais mais pobres se estrutura confirmando tal modelo: favela em áreas centrais, os loteamentos clandestinos e ocupações no subúrbio e na periferia (Zona Oeste) da cidade, marcadamente os conjuntos habitacionais como lugar de moradia daqueles removidos de favelas localizadas em áreas centrais e valorizadas da cidade. Porém, em comum entre todos esses processos de produção do espaço urbano, há a ausência-ineficiência de infra-estrutura urbana, como a precariedade no acesso à água. O morador Valdir Claudino, do Morro da Mangueira, 65 anos, relata: "Nessa época, era muito mais fácil ter luz no morro do que água. Sempre tinha um vizinho que conseguia um 'gato' e distribuía entre os amigos. Água encanada de verdade só nos anos 80 (...) E em algumas partes do morro, fraquinha e era um dia com água, dois sem”30.

Inaugurada às pressas para receber milhares de famílias desabrigadas pelo temporal de 1966, o conjunto habitacional da Cidade de Deus tinha graves problemas de infra-estrutura, inclusive falta d'água. "Tinha uma música que o povo cantava que era o seguinte: 'Cidade de Deus, Cidade de Jesus, de dia falta água, de noite falta luz'. Só por aí já dá para sentir o clima”, conforme explicita Ana Lúcia, 49 anos, que foi para a Cidade de Deus removida do Morro da Formiga.

A distância em relação ao centro da cidade (e conseqüentemente aos serviços e postos de trabalho lá existentes) nesse momento em intenso processo de metropolização inseria a Zona Oeste em um quadro em que grande parte dos moradores da cidade a consideravam como última opção de moradia. Isto porque a expansão do centro em direção aos bairros suburbanos cortados pelas ferrovias e às áreas "rurais" (Campo Grande, Santa Cruz e Guaratiba, os antigos sertões cariocas) assentava-se num processo bastante diferenciado daquele que caracterizava a ocupação da Zona Sul da cidade (VIEIRA, 2004; MAIA, 2007). Sobretudo no antigo "sertão carioca" 31 metamorfoseado em periferia distante, a população

\footnotetext{
${ }^{29}$ Abreu (1995) demonstrou como o deslocamento da questão social, substituindo como habitação popular os cortiços das áreas centrais pelo subúrbio e favelas e posteriormente loteamentos periféricos, foram na verdade um movimento de resolução do problema imediato e paliativo de diversas ordens: higienismo, ideal de modernidade, mas também a "explosividade potencial do centro da cidade, em caso de conflito social, e a dificuldade logística de controlá-lo face à estreiteza do plano viário colonial ainda existente". Na medida em que esvaziou o potencial conflitivo da forma da habitação para o habitat, isto é, houve algo como que uma distensão proporcionada pelo rearranjo de contingentes da população para áreas não-valorizadas do capital financeiroimobiliário.

${ }^{30}$ Depoimento cotejado do centro de pesquisa Favela tem Memória.

${ }^{31}$ Mota (2009: 20) aponta que "a expressão foi utilizada por Magalhães Corrêa (1936). Trata-se de um estudo realizado na década de 1930 sobre os subúrbios do Rio de Janeiro, especificamente a região correspondente a Zona Oeste da cidade. Segundo Amado (1995:145), os portugueses já empregavam a expressão — sertão desde o
} 
mais pauperizada era induzida a se instalar em loteamentos situados em áreas praticamente destituídas de infra-estrutura urbana (MAIA 2007, 2008).

Com uma atuação deliberadamente discriminatória sobre o espaço, empreendida pelo Estado autoritário na ditadura civil-militar, as áreas de moradia das classes sociais mais abastadas foram alvos de uma atenção especial, recebendo prioridade no que tange a investimentos públicos (em termos de infra-estrutura urbana), enquanto aos mais pobres restava a inexistência ou a ineficiência das políticas públicas (MAIA, 2007). O proletariado urbano sofria ainda um contundente processo de segregação socioespacial induzido, sobretudo em razão da "política de remoção de favelas" assaz violenta, política esta que repercutiu drasticamente no seu cotidiano (VALLADARES, 1980). Por exemplo, o Conjunto Habitacional Otacílio Câmara (Cesarão) e o Conjunto Habitacional Maestro Olímpio dos Santos (Urucânia) ${ }^{32}$ dentre outros, foram construídos durante a década de 1970 e inaugurados no ano de 1980 para receber os removidos das favelas das áreas centrais e consolidadas.

A (im)possibilidade do urbano voltava-se para a Zona Oeste da cidade. A ela, acorriam as classes sociais que não mais podiam resistir à especulação imobiliária e aos impostos cobrados nas regiões centrais. Em sua busca iam também os removidos das favelas, além dos migrantes, que já (não) chegavam às metrópoles com a esperança de morar próximo ao trabalho e desfrutar de todos os bens e serviços que a cidade poderia oferecer-lhes (MAIA, 2007; 2008), ou seja, há uma manifestação peremptória da relação entre a produção do espaço e a condição proletária nesse fragmento da cidade.

Assim, Maia (2007) e Faria (2004), sob pontos de vista diferentes, chegam a uma conclusão muito próxima. As autoras constatam que morar distante do centro da cidade (que ainda mantinha a centralidade que se referia a oferta de postos de trabalho e serviços públicos, comércio, cultura, etc.), antes de se constituir numa opção, tornar-se-ia uma condição imposta às classes sociais mais pobres, conferindo a bairros como Santa Cruz, Paciência e Sepetiba a característica de bairros dormitórios para a maioria de seus residentes.

Fernandes (2009) ao analisar o trabalho de Perlman (1979) afirma que a favela nas áreas centrais era uma solução funcional para muitos dos problemas enfrentados por seus moradores, oferecendo acesso relativamente próximo a trabalho e serviços. Esse não era o caso dos conjuntos habitacionais para onde foram mandados. Os moradores eram separados

século XV —-também para nomear espaços vastos, interiores, situados dentro das possessões recém-conquistadas ou contíguas a elas, sobre os quais pouco ou nada sabiam. A autora informa que o termo foi utilizado até o final do século XVIII pela Coroa portuguesa. Também aparece na cartografia do período colonial da cidade do Rio de Janeiro, a grafia - certão apontando para os limites da cidade".

${ }^{32}$ Realizamos trabalhos de campo nesses dois locais. Explicitaremos nossas experiências e vivências no capítulo 3. 
de suas relações de parentesco e amizade, encontravam-se distantes de seus locais de trabalhos, e de escolas e hospitais. Além disso, eram cobrados pagamentos mensais muito além das possibilidades de seus salários, conforme expõe a autora. Perlman (1979) relata que eram cobrados por mês pelas moradias pagamentos no valor de cerca de $25 \%$ das rendas familiares dos moradores. O custo do transporte nos deslocamentos das moradias até o trabalho era tão alto que geralmente apenas um membro da família conseguia arcar com as despesas e continuar trabalhando, o que resultou em uma grande queda na renda familiar. Famílias que atrasavam muito nos pagamentos eram levadas para centros de triagem, abrigos ainda mais distantes do centro da cidade, em um local chamado, ironicamente (ironia que demonstra a tragédia), de Paciência (bairro que contém as favelas em que realizamos nossos trabalhos de campo). Essa política aumentou o desemprego, acabando com muitos dos pequenos serviços e "bicos" que os membros das famílias poderiam ter enquanto cuidavam de seus filhos, ou após a escola, conforme expõe a pesquisa. As discussões de Perlman (1979) exploram tais questões em profundidade, contestando a validade dessas suposições que embasavam abordagens behavioristas, e mostrando a utilidade estrutural, funcional e política dos mitos em relação às condições objetivas da pobreza e do desenvolvimento desigual. Valladares (1980) demonstrou na obra "Passa-se uma casa" que muitos moradores venderam suas casas e retornaram para as favelas onde foram removidos.

A Zona Oeste, por contar com terrenos a preços acessíveis, em decorrência do parcelamento de grandes glebas (ocorrido entre 1963 e 1967), tornou-se uma área bastante procurada pelas classes mais pobres (LAGO, 1990). Na década de 1970, Santa Cruz passou a contar ainda com uma Zona Industrial:

acompanhando o processo de reestruturação urbana e de espraiamento da Cidade, o que também contribuiu para o crescimento populacional do bairro e de seu entorno, mas com precária infra-estrutura. Empresas de porte buscaram esta área para instalação de indústrias, como a Latasa, Glassurit, Ecolab. A Casa da Moeda do Brasil, a COSIGUA (do Grupo Gerdau), a White Martins, a Valesul, a Usina Termoelétrica de Furnas, ocupando áreas que, anteriormente, eram destinadas à lavoura e à pecuária. A população do bairro, contudo, foi pouco beneficiada através deste processo, sobretudo pelo fato destas empresas exigirem mão-de-obra qualificada e, por isso mesmo, inexistente na área. Daí ser ainda comum a circulação, pelo bairro, de "linhas de ônibus", mantidas por estas indústrias, responsáveis pelo transporte de funcionários oriundos de outras localidades. (MAIA, 2007: 12)

Com a degradação do poder de compra do proletariado urbano, constata-se um novo pico de favelização no Rio de Janeiro da década de 1980 até hoje, tendo como espaços principais a Zona Oeste, a Barra da Tijuca e Jacarepaguá (MAIA, 2007). Conforme apontado por Fridman (1994) apud Maia (2007), as favelas surgidas neste momento acabariam por 
localizar-se "em áreas non aedificandi, destinadas a praças, afastamentos em torno dos rios, etc. [tendo as ocupações de terrenos tornado-se] outro recurso de habitação popular, [bem como] os loteamentos irregulares e clandestinos, localizados, principalmente na Zona Oeste". Fridman (1994), Lago (1990), Faria (2004) e Maia (2007) sugerem que, nesta década, deu-se "uma redefinição espacial da pobreza e da moradia".

Fica evidente, a partir dos elementos até então apresentados, que a Zona Oeste especialmente os bairros de Santa Cruz, Paciência e Sepetiba - é uma área que, no contexto carioca tem, ao longo dos anos, se constituído paradigmática para a compreensão de processos de segregação induzida, da presença/ausência do Poder Público em relação às demandas de seus moradores.

Faria (2004) disserta no que tange ao processo de produção do espaço da Zona Oeste do Rio de Janeiro, principalmente a partir das décadas de 1990 e 2000, sobre a constituição do processo da "desfavelização" das favelas das áreas centrais e nobres e a favelização da periferia da cidade do Rio de Janeiro. Esse processo não significa, nem de longe, a erradicação de tais favelas, vide o crescimento de favelas como Rocinha e Vidigal na Zona Sul (LEITÃO, 2009). Todavia não se pode negligenciar que o processo de remoção de algumas favelas continua a acontecer, com a utilização de metáforas ${ }^{33}$ políticas e ambientais.

Ocorrem na realidade modificações das características que definiam as favelas das áreas centrais e nobres até o final da década de 1970, ou seja, acesso pela ocupação de terreno, predomínio de habitações precárias, ausência de infra-estrutura, traçado urbano com múltiplas racionalidades instituídas pela dinâmica de adaptações ao espaço geográfico circundante e as relações sociais tais como parentesco, com população constituída de migrantes pobres de outras regiões do país (FARIA, 2004).

A “desfavelização” (FARIA, 2004) decorre das mudanças na estrutura interna (política e socioeconômica) que estão ocorrendo na produção do espaço urbano, especialmente nas favelas, devido à mercantilização dos imóveis e do direito de construir, aos programas de

\footnotetext{
${ }^{33}$ As declarações do Estado e dos editoriais dos meios de comunicação de massa ressaltam a importância da remoção da população em "áreas de risco" em nome da "segurança das próprias pessoas". Trata-se em nosso entender e apoiados em Alentejano (2010) da volta metaforizada das medidas de remoção das favelas que longe de proteger os mais pobres acentuou as mazelas sociais. "Ou esquecemos que as favelas removidas do entorno da Lagoa Rodrigo de Freitas deram lugar a prédios de alto luxo enquanto a população que aí residia foi deslocada para lugares como a Cidade de Deus, repleta de problemas de infra-estrutura e internacionalmente famosa pela violência. Se o propósito é realmente o de proteger os trabalhadores que moram nas "áreas de risco", então vamos destinar imediatamente para moradia as centenas de prédios - alguns inclusive públicos que se encontram hoje vazios na cidade e no estado do Rio de Janeiro. Podemos começar pelos da região portuária do Rio, onde há inúmeros prédios e terrenos públicos e privados abandonados." (ALENTEJANO, 2010:2). Essa área, todavia, será palco para grandes intervenções dos mega-empreendimentos imobiliários para a Copa do Mundo e para as Olimpíadas na cidade do Rio de Janeiro.
} 
urbanização e regularização fundiária, assim como às "melhorias habitacionais empreendidas pelos moradores" como observa Faria (2004). Esses processos acarretam uma valorização do preço dos imóveis e, consequentemente, uma mudança no perfil da população moradora de favelas nas áreas centrais e nobres, levando a repensar a noção de favela como espaço homogeneamente definido como a moradia dos pobres. A produção de espaços anteriores a tal valorização e posteriormente remetem a essa dialética que ocorre na estrutura interna de tais favelas, umas já dotadas de uma série de serviços e outras em espaços precariamente dotados de infra-estrutura. A dominância financeira e a preponderância do econômico em relação ao político e ao social demonstram sua aparência real nas modificações da produção e reprodução do espaço urbano nas metrópoles.

As normas e regulações urbanísticas impostas pelos programas, que restringem e coíbem a expansão e verticalização, impedem a principal forma de reprodução das famílias, que é a possibilidade de permanência dos familiares e seus descendentes no mesmo lote e/ou residência. Faria (2004) aponta a possibilidade que parte da população que compõe as favelas recentes seja a segunda ou terceira geração de migrantes da década de 1960 e 1970.

O segundo processo, a favelização da periferia (FARIA, 2004 - Ver Tabela 2), é concorrente com o primeiro, mas as mudanças intrínsecas à dinâmica urbana na periferia também contribuem para o aumento no número de favelas na região. A principal delas é a expansão do mercado empresarial e dos serviços para a classe média alta, localizado em áreas como a Barra da Tijuca e o Recreio dos Bandeirantes e o crescimento de áreas da periferia como Campo Grande (VIEIRA, 2004).

Tabela 2: Área ocupada pelas favelas segundo as Áreas de Planejamento (AP) e total do município do Rio de Janeiro

\begin{tabular}{|l|r|r|r|}
\hline $\begin{array}{c}\text { Áreas de } \\
\text { planejamento }\end{array}$ & \multicolumn{2}{|c|}{ Área em m } & \multicolumn{1}{c|}{ Variação } \\
\hline Total & 1999 & \multicolumn{1}{c|}{2008} & $1999-2008$ \\
\hline AP 1 & $\mathbf{4 2 . 8 9 4 . 4 6 4 , 1 7}$ & $\mathbf{4 5 . 8 4 3 . 5 0 9 , 3 5}$ & $\mathbf{6 , 8 8 \%}$ \\
\hline AP 2 & $2.287 .901,18$ & $2.374 .235,40$ & $3,77 \%$ \\
\hline AP 3 & $4.178 .368,29$ & $4.175 .540,10$ & $-0,07 \%$ \\
\hline AP 4 & $17.511 .859,90$ & $18.320 .650,04$ & $4,62 \%$ \\
\hline AP 5 & $6.320 .269,33$ & $6.916 .320,73$ & $9,43 \%$ \\
\hline
\end{tabular}

Fonte: Cavallieri, 2009 
Lago (2003:8) afirma podermos

inferir que o surgimento e expansão de novas favelas (localizadas predominantemente na zona oeste) têm se dado através da mobilidade espacial no interior do próprio município, seja do bairro para a favela, seja de favelas consolidadas para favelas recentes. A fuga do aluguel, tanto no mercado formal quanto informal, e a redução da oferta de habitação ou lote popular pelo poder público explicam essa mobilidade em direção às favelas periféricas. Vale lembrar que o valor do aluguel de um imóvel nas favelas das zonas sul e norte pode equivaler, hoje, ao de um apartamento em Copacabana ou no Centro. Já a mobilidade intra-municipal tem menor peso explicativo quando se observa o incremento populacional nas favelas já consolidadas das zonas sul e suburbana. Na zona sul da cidade cerca de $40 \%$ do incremento da população favelada, nos primeiros cinco anos da década de 90, era composto por migrantes de fora do município, em sua maior parte do nordeste. Nesse sentido, a possível "expulsão branca", gerada pela valorização imobiliária, de residentes mais pauperizados das favelas centrais é, em certa medida, compensada pela "entrada" nesses espaços de uma população migrante cujo perfil social era, em média, inferior ao dos já residentes. Nesse caso as relações de reciprocidade, através das redes familiares, ainda funcionam, para o migrante recém chegado, como importante mecanismo de acessibilidade à moradia e de inserção na economia urbana. A localização dessas favelas em áreas com grande demanda por trabalho de baixa qualificação no setor de serviços e construção civil se mantém como fator central para essa inserção do migrante.

Porém, o empobrecimento do proletariado urbano não tem inviabilizado o acesso à moradia na periferia distante, por exemplo, nas ocupações clandestinas e na compra de lotes (muitas vezes vendidos de modo irregular por loteadores). Embora num ritmo bem inferior ao dos anos 1950 e 1960, o mercado informal de lotes populares nos municípios localizados na fronteira metropolitana do Rio de Janeiro e na Zona Oeste da capital, garantiu, nas duas últimas décadas, taxas de crescimento demográfico acima de $3 \%$ ao ano, e as mesmas condições de carências urbanas das décadas anteriores (LAGO, 2003). Como argumentado anteriormente, esse é o lado menos visível da precarização da produção de moradia para os moradores pobres das metrópoles, face oculta da ilusão da transparência que se apresenta com conteúdos perversos na espoliação urbana do proletariado imerso na crise do trabalho.

A face mais visível é a ocupação dos loteamentos, que a partir da década de 1980 se difundem pelo tecido urbano da metrópole com carência ou ausência de infra-estrutura urbana. No processo de crise da cidade, os meios de vida - como a água - são introduzidos no grupo das necessidades urbanas sob uma nova ótica de consumo e distribuição: a da apropriação individual (PENNA, 2002). A água, distribuída principalmente por organismos estatais (porém atualmente sendo objeto de disputa pelas empresas transnacionais de saneamento), torna-se um bem que só pode ser adquirido pela população individualmente. $\mathrm{O}$ 
abastecimento é realizado pelas concessionárias de água através da rede geral. Objetiva-se então, regularizar a distribuição de água nas cidades. Regularizar o abastecimento de água, é claro, é sinônimo de pagar pela água. De fato o que ocorreu (e o que ainda ocorre): a classe trabalhadora moradora das favelas e das periferias auto-construiu a infra-estrutura de abastecimento de água realizando ligações clandestinas (os gatos d'água).

A produção da habitação também sai da construção pública e coletiva (financiada pelo BNH e FGTS até ser extinto em 1986) para o domínio privado, particular e bancário, manifestado, por exemplo, na década de 2000 e no início da década de 2010, pelo Programa Minha Casa Minha Vida.

A partir da década de 1990, outro aspecto deve ser ressaltado nos estudos urbanos, principalmente os relacionados às classes sociais mais pobres, que é a questão da violência ainda mais radical e da sociabilidade violenta, apresentado elementos ainda mais tensos à barbárie capitalista e à urbanização crítica das periferias distantes das metrópoles.

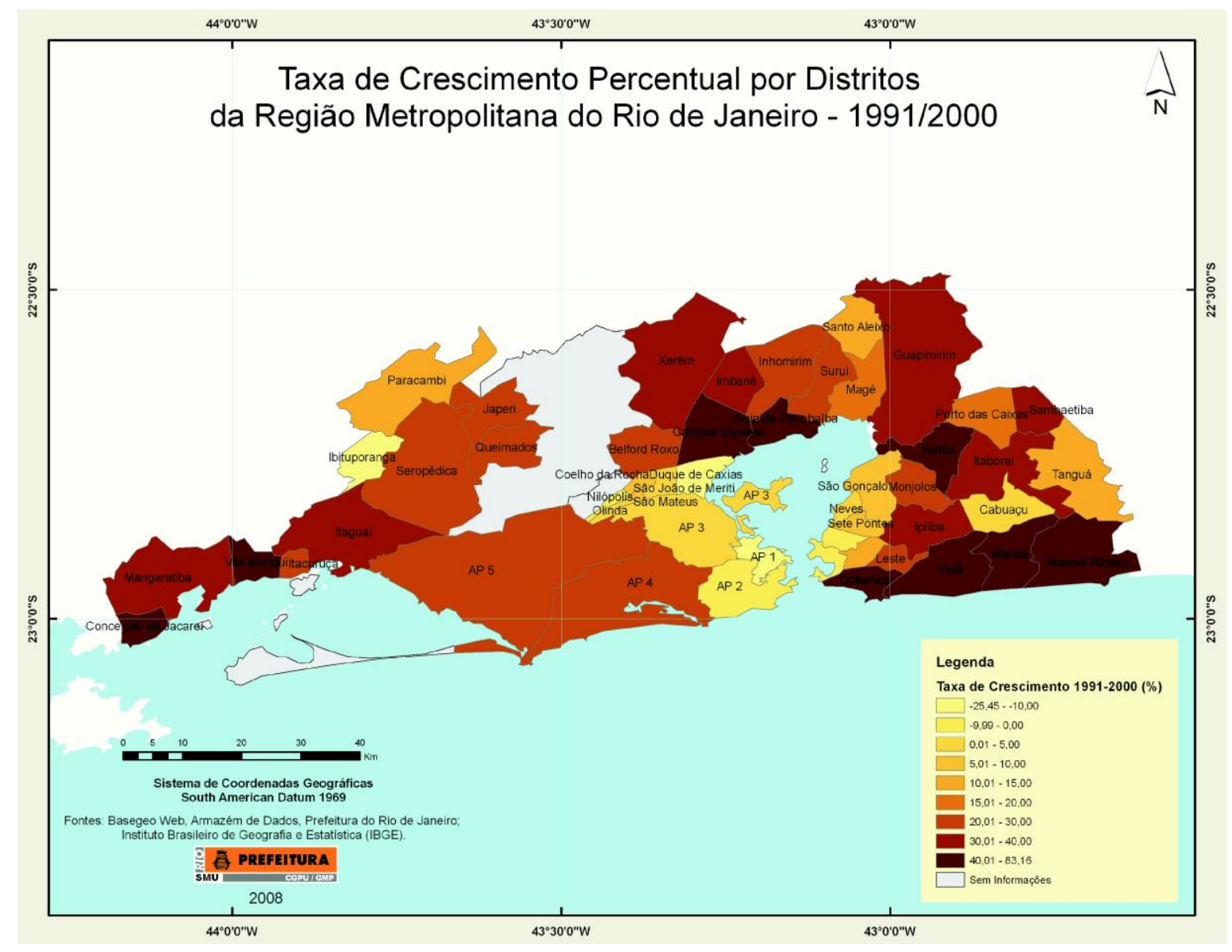

Fonte: Plano Diretor, 2010

Mapa 3: Taxa de crescimento percentual por distritos da Região Metropolitana do Rio de Janeiro (2000). Na cidade do Rio de Janeiro percebe-se o incremento nas Áreas de Planejamento 4 e 5. 


\subsubsection{A ilusão da transparência na urbanização de favelas e no Programa Favela-Bairro}

A urbanização de favelas tem um marco e uma resistência. A luta dos moradores contra as remoções em Brás de Pina no Rio de Janeiro foi brilhantemente detalhada por Carlos Nelson Ferreira dos Santos (1981) e Gilda Blank (1982). Fato este que desencadeou a permanência dos moradores, depois de uma série de idas e vindas, conjunturas políticas favoráveis e muita luta em prol de intervenções urbanas e dotações de infra-estrutura na favela da Zona Norte da cidade.

Em décadas anteriores já havia um conjunto de reivindicações no âmbito da urbanização de favelas, porém sem essa mesma projeção e possibilidade real de resistência. Há que se distinguir no que tange a urbanização das favelas o momento em que a urbanização se constituiu em bandeira das reivindicações de movimentos populares contrários às práticas de erradicação e de remoção de favelas; da urbanização autoritária imposta pelo aparelho do Estado conformados, por exemplo, nos "parques proletários" na década de 1940 conforme Burgos (2006) analisou, submetidos à rígida disciplina imposta pelo Estado Novo, e, mais tarde, para conjuntos habitacionais distantes no subúrbio e na Zona Oeste, financiados pelo governo militar (DAVIDOVICH, 2000). Os movimentos pela urbanização expressavam a consciência do crescimento da urbanização e do direito de pertencer à cidade. Apoiados por parte da imprensa e por setores da Igreja Católica, eles alcançaram projeção política, a ponto de serem reprimidos pelo regime militar, passando das associações de moradores ao controle de secretarias do governo estadual (DAVIDOVICH, 2000). Progressivamente, a bandeira da urbanização da favela foi sendo apropriada pela política pública, que se fixou na habitação e, secundariamente, no saneamento, especialmente no abastecimento de água (DAVIDOVICH, 2000; BARREIRA e BOTELHO, 2003). O Estado, neste momento, irá realizar as políticas públicas buscando a visibilidade de suas ações, e também a forma de negociar as intervenções numa lógica em que estão imersas construtoras, empreiteiras e o aumento no recolhimento de impostos quando do pagamento dos serviços prestados pelo Estado. Crescia, deste modo, a percepção do aparelho de Estado a respeito da importância do respaldo do proletariado urbano para a sustentação do poder e para um aumento das tributações dos moradores das favelas. Davidovich (2000) apresenta outro argumento, afirmando que a urbanização dos fragmentos do espaço das classes sociais mais pauperizadas como um suporte acenava, politicamente, um descompromisso com o elitismo atribuído a diretrizes do governo. Pensamos porém que esse argumento é demasiado neoinstitucionalista, pois a urbanização como negócio é portadora e reveladora de contradições na produção e reprodução do espaço urbano na formação das 
metrópoles, sendo que mesmo acenando para um posicionamento menos elitista, o aparelho de Estado incorpora a urbanização como um momento do consumo do espaço, no qual a reprodução da vida e o valor de uso do espaço estão subsumidos pela reprodutibilidade econômico-financeiro-imobiliária e pelo valor, expresso no espaço como valor de troca.

Nessa perspectiva, passou, contudo, a prevalecer uma forma de intervir de cunho autoritário, envolvendo a esfera federal e estadual, que permaneceu de maneira ainda mais violenta conforme as contradições foram se acirrando, da fase democratização do país, pós 1985 e sob a égide de administrações eleitas, quando ocorreu um reforço dos negócios urbanos, e não seu recrudescimento. Rearranjos acontecem com a crise da habitação na década de 1980, marcada por achatamento salarial, crise do trabalho ${ }^{34}$ e encarecimento da terra, um percurso de crises inserido na crise estrutural do capital. $\mathrm{O}$ acesso à moradia se dá na expansão de loteamentos em periferias mais distantes e no crescimento de favelas nas periferias. A precarização da infra-estrutura urbana se realiza em conjunto com a esperança de que suas habitações sejam inseridas em políticas de urbanização de favelas e de regularização fundiária. Porém, os títulos de propriedade privada são mais um momento da urbanização como negócio, sinônimo de realização da vida via consumo de bens, serviços e infraestrutura, possibilidade da realização da terra como mercadoria juridicamente reconhecido

\footnotetext{
${ }^{34}$ Dialogamos com as constatações de Damiani (2009) acerca da crise do trabalho, contida na crise do capital. Esta crise se manifesta "como desemprego maciço; aumento da composição orgânica do capital dos empreendimentos econômicos, que reduz proporcionalmente o trabalho vivo da referida composição; uma economia de "sobrevivência", em novos moldes, pois, diante da crise do trabalho, setores produtivos e de serviços, de baixa composição orgânica do capital, são mantidos e, pulverizadamente, ampliados". Para Francisco de Oliveira estamos diante de um trabalho que agora é comandado pela superacumulação de capital. Superacumulação não significa só (embora signifique também) que há máquinas, equipamentos, processos em excesso. Superacumulação, em Marx, quer dizer excesso de trabalho desempregado. E é motivado pela enorme aceleração das forças produtivas. Então se dá esta relação estranhada: há superacumulação de capital no sentido de uma massa "informal" - sem relações trabalhistas -, mas que está ocupada e não inteiramente desocupada. Oliveira afirma que "os desempregados são a fração que as pesquisas mostrarão como pessoas que não têm emprego formal. Cruzamos com o que eles fazem no cotidiano, e vemos que a maior parte dos desempregados está ocupada, vendendo todas as formas de produtos: produtos pirateados, bebidas e balas no trem". O Estado atua ainda fortemente na repressão. O "choque de ordem", em vigor desde o dia 5 de janeiro de 2009, que representa os pressupostos da atual gestão da Prefeitura da cidade do Rio de Janeiro, tem por objetivo realizar operações de repressão a vendedores ambulantes, flanelinhas, moradores de rua, construções irregulares e publicidade não autorizada. Tem no comando das ações o Secretário Especial de Ordem Pública, Rodrigo Bethlem, mobilizando uma equipe de cerca de 2.000 servidores formada pelo aparato repressivo do Estado: guardas municipais, PMs, fiscais, etc. Em 11 de maio de 2009, a Secretaria de Ordem Pública do Rio divulgou o resultado dos cinco meses iniciais da operação choque de ordem. $\mathrm{O}$ termo convencionalmente utilizado pelo Poder Público para caracterizar as ações é "combate a desordem urbana". No entanto, a autorização para ação coletiva do "Choque de Ordem" tem consistido em tratar diversos casos em uma "operação", violando, coletivamente, o exercício da profissão "informal", dos processos judiciais quanto a moradias em ocupações ou, quanto à moradia da população em situação de rua no trem que liga Santa Cruz ao Centro do Rio de Janeiro. Assim fala Terezinha, vendedora de doces, balas e principalmente amendoim: "Meu filho, depois de Realengo ninguém lembra, choque de ordem é na Zona Sul ou na praia. Quem quer saber de Santa Cruz? Mas de vez em quando aparece o rapa da Supervia e toma os produtos, dá tapa, não importa, homem, mulher, criança e ainda sai falando em choque de ordem."
} 
pelo Estado capitalista e portador do atributo intrínseco a propriedade que é a possibilidade da expropriação.

Assim, não foi difícil reconhecer, passada a ditadura civil-militar, que a favela poderia e deveria ser reconhecida como um espaço de moradia própria, justificável e legítimo, afinal a favela era um grande negócio. Principalmente a partir do primeiro governo de Leonel Brizola (1983-1987) reforça-se a idéia de que é possível converter a favela em espaço de habitação popular regular, legalizando a propriedade da terra e criando/reforçando a infra-estrutura de saneamento (MAMEDE, 2005). O governo Brizola transformou em política pública o que antes era apenas aleatório ou subentendido: a legitimação da favela como moradia popular (BARREIRA e BOTELHO, 2003). E esta continuidade é marcada por uma nova conjuntura econômica nacional e mundial sob a qual as principais ações e resultados combinados são: inserção precária, intervenções do Estado na infra-estrutura e serviços de saneamento, legalização da posse para a regularização fundiária e um tratamento considerado possível, frente aos espasmos (cada vez mais críticos) da crise estrutural do capital e a incapacidade global de intervenção urbana do Estado, do tratamento dispensado à favela como o local próprio das classes sociais mais pobres, assalariados precários e trabalhadores informais. $\mathrm{Ou}$ seja, na produção discursiva da ausência de capacidade técnica e financeira de reformulação urbana radical, a alternativa que tornou-se discursivamente viável para resolver o problema da habitação popular e conduzi-lo oficialmente nos moldes do que já vinha sendo feito “espontaneamente” foi a postergação do problema (BARREIRA e BOTELHO, 2003).

Barreira e Botelho (2003) continuam suas ponderações argumentando que as políticas de saneamento e de criação de infra-estrutura e legalização do governo Brizola - cujo Programa de Favelas da Companhia Estadual de Água e Esgotos (PROFACE) entre 1983 e 1985 distribuiu água e esgoto a cerca de 60 favelas da cidade do Rio de Janeiro - não são apenas políticas "populares", mas igualmente realpolitik no sentido mais preciso.

Evidentemente se o Estado inserido na crise estrutural e sob a subserviência da dominação financeira, imprimidas pelas frações de classe burguesa que o gerem, não enfrenta a questão urbana de modo radical, resta a alternativa política e urbanisticamente mais simples (fruto inclusive da alienação política conforme argumentou MARX, 2005) e menos custosa (e mais lucrativa) de legitimação e manutenção da favela como moradia popular, mediando problemas através do instrumento do planejamento submetido à mercadoria (a urbanização capitalista de favelas).

Em certo sentido, portanto, a política urbana da década de 1980 e do governo Brizola e de seus sucessores é um prelúdio da doutrina neoliberal que o aparelho de Estado em nível 
estadual e municipal esteve encastelando durante a década de 1990 e 2000 . Não é por acaso que as ações, declarações e documentos do BID e do Banco Mundial (ARANTES, 2007) nesse período já reforçam o papel que as favelas teriam no novo modo de proceder da política mundial.

O programa Favela-Bairro, implementado na cidade do Rio de Janeiro na década de 1990, tornou-se a principal manifestação dos ajustes econômicos no tratamento da questão urbana e do problema habitacional no Brasil: as urbanizações de favelas valorizando as áreas centrais, consolidadas e nobres (zonas norte, central e sul) da cidade, instituindo um mercado de imóveis nas favelas, paralelo e conjunto a um processo de "expulsão/remoção branca" dos moradores dessas áreas (FARIA, 2004; LAGO, 2003). A urbanização crítica se espraia, configurando novas centralidades e periferias. Assim, com o espaço concebido do esquadrinhamento urbano, urbanizam-se favelas com o slogan de "integração favela-bairro".

As políticas urbanas acabam por reforçar a hipótese formulada por Henri Lefebvre (1978) atrelada à esteira do capital privado, de que reproduzem o modelo que é o de tentar colocar ordem, fazer a cidade funcionar como máquina, onde não há apenas desordem, e sim contradição. A reprodução da vida encontra-se ameaçada nas periferias distantes das cidades (MENEGAT, 2009) que, oficialmente, são denominadas de "invasões", "aglomerados subnormais" ou "fábrica de produzir marginais", conforme afirmação do governador do Rio de Janeiro Sérgio Cabral Filho.

O aparelho de Estado negligencia que os custos sociais da negação do direito à cidade serão muito mais elevados que os de sua realização. Excluir do urbano grupos, classes, indivíduos, implica também excluí-los da civilização, até mesmo da sociedade. O direito à cidade legitima a recusa de se afastar da realidade urbana por uma organização discriminatória segregadora. Esse direito do cidadão anuncia a inevitável crise dos centros estabelecidos sobre a segregação e que a estabelecem: centros de decisão, de riqueza, de poder, de informação (LEFEBVRE, 2008).

Porém, a ação de negação do direito à cidade se realiza na segregação pela ação do Estado, isto é, pela elevação dos preços da terra em certas partes da cidade, como resultado de investimentos e obras públicas e pela expulsão de grupos sociais de baixa renda de certas partes da cidade em vias de valorização (mega-eventos, mega-investimentos, megaempreendimentos, a sociedade do espetáculo necessariamente precisa desses superlativos). Esse processo contém a virtualidade da expulsão de alguns grupos sociais e sua substituição por outros, homogeneizando cada vez mais cada espaço a partir da economização do território. Isso ocorre regularmente nas mais importantes cidades brasileiras por meio dos 
processos de remoção de favelas e também para a construção de obras públicas como grandes projetos de infra-estrutura, fundamentando a urbanização como negócio. Outros exemplos aparecem nos mega-eventos esportivos, no city marketing e na militarização das favelas em áreas nobres, valorizadas ou que são próximas aos acessos de deslocamento de turistas e investidores.

No final do século XX, a forma de intervenção do Estado assumiu novas configurações que permitiram a combinação de repressão sistemática e políticas de "alívio à pobreza”. Cabe aqui mencionar as ações empreendidas pela prefeitura do Rio de Janeiro nas administrações de César Maia (1993-1996; 2001-2008), Luiz Paulo Conde (1997-2000) e Eduardo Paes (2009-2010), pautadas por uma filosofia da "reconstrução" da cidade e agora, imbricado com a "pacificação" das favelas, trazendo à tona os discursos e práticas da metrópole empreendedora e competitiva na formulação de seus principais projetos. Esta tendência pode ser percebida com a ênfase dada por obras de grande porte como o Programa Rio Cidade e o Programa Favela Bairro, nas duas primeiras gestões. E também nos muros no entorno das favelas, denominados "ecolimites", e as Unidades de Polícia Pacificadora, na última gestão.

Peremptoriamente, é certamente nas grandes cidades da periferia do capitalismo que a crise adquire sua face mais perversa, submetendo gigantescas massas de pobres e miseráveis à crise do trabalho, transmutação do habitar à habitat e a "naturalização do homem". Este parece ser o elemento central da crise urbana atual: o futuro é absolutamente negado para uma parcela cada vez maior de moradores pobres da cidade (MENEGAT, 2003). O crescimento constante da violência urbana é, sem dúvida, um indicador eloqüente do agravamento desta situação. A análise dos conflitos em torno do domínio do território tornou-se chave para a explicação da atual configuração da realidade social.

Para coibir tais ações, acreditamos como Lefebvre (2008b) que se realiza um espaço instrumental que permite tanto impor uma certa coesão (pela violência), quanto dissimular as contradições da realidade (sob uma aparente coerência racional e objetiva). Aqui os termos coesão e coerência significam regulação buscada, pretendida, projetada, o que não quer dizer obtida. Leituras da contradição urbana sob a espessa camada de opacidade e de transparência que refletem como espelho convexo deturpando a realidade. Assim afirma Sandra Cavalcanti (secretária de Serviços Sociais do Estado da Guanabara e coordenadora das remoções de favelas durante a década de 1960, e que desempenhou importante papel no desenvolvimento do Programa Favela Bairro na década de 1990) e o Coronel Marcus Jardim (comandante do 
$16^{\circ}$ Batalhão de Polícia Militar na Penha, Zona Norte do Rio de Janeiro, onde se localizam os Complexos de Favelas da Penha e o Complexo de Favelas do Alemão) respectivamente:

A única solução que existe para se recuperar um território que está em poder do inimigo é iniciar uma ação bélica. Trata-se de pôr em prática uma tática de guerra, com a ocupação, ostensiva e poderosa de todo o território a ser conquistado. Ocupada militarmente a área reconquistada, os moradores devem ser ajudados a sair dali, pois o território reconquistado vai ser liberado da presença do crime. Vai ser reflorestado, se for o caso. Ou vai servir para uma escola, para um posto de saúde ou para uma delegacia. Enfim, vai ter uma destinação pública e social. Ao reassentar os moradores em suas novas residências, o poder público deve cuidar para que eles possam ter, daí em diante, a mesma qualidade de vida de qualquer cidadão carioca, livre de quadrilhas e de chefes de gangues. (Trecho de artigo publicado por Sandra Cavalcanti no Jornal do Brasil de 4 de novembro de 1996, intitulado "Por trás das balas" apud Lago e Ribeiro, 2000:1)

- Falei durante uma hora sobre a necessidade de se buscar resultados, tendo a legalidade como suporte e a legitimidade sempre no ar. É botar a mão no fuzil e cair pra dentro. A sociedade quer respostas. (Coronel Marcos Jardim, em O Dia online, 30 abr.2009).

Seguindo caminhos propostos por Lefebvre, pode-se pensar a crise urbana como crise das formas estruturadas de apropriação do espaço social e, indissociadamente, crise dos conteúdos estruturados da ação social, como crise do sujeito e da sua objetividade: desordem e instabilidade, então, que se estendem à totalidade dos domínios da vida social (MENEGAT, 2004).

Como argumenta Carlos (1996), enquanto materialização do trabalho social a cidade é instrumento de criação de mais valia, é condição, meio e produto para a constituição de múltiplas relações, inscritos no uso do solo urbano. Na sociedade capitalista este estará determinado pelo processo de troca que se efetua no mercado, pelas ações da reprodução ampliada do capital.

Para Faria (2004), Smolka (1992) e Cenecorta e Smolka (2000), o mercado do solo tem sido outro elemento responsável pela segregação da população pobre nas periferias, pois o proletariado urbano não possui recursos e condições para adquirir solo para moradia sob as condições do mercado de terras. Para os autores supracitados, esse processo ocorre devido as características especulativas do mercado e a baixa intervenção do Estado para regular preços.

Para Cenecorta e Smolka (2000), os preços praticados no mercado de terras são extremamente superiores aos de "produção", porque existe uma sobretaxa ou sobrelucro extraordinário por parte dos loteadores, derivado da grande diferença entre o "custo original 
da terra" e o "preço de venda". Esse sobrelucro se sustenta porque existe uma oferta limitada em relação à demanda ${ }^{35}$ (CENECORTA e SMOLKA, 2000).

A segregação via ação do mercado é um outro momento de negação ao direito à cidade. Em grande parte, este se realiza pela ação dos incorporadores imobiliários que controlam as melhores localizações, especulam com a terra urbana e lucram com as mudanças de uso dos terrenos e glebas. Mecanismos ligados à dinâmica de valorização do preço do solo urbano promoveriam competição por terra urbana entre usos não-residenciais e residenciais de grupos sociais mais ricos e usos residenciais de classes sociais mais pauperizadas.

Nesse contexto, desenvolve-se um novo modo de pensar e administrar o social, caracterizado por um tratamento individualizante e individualizador dos problemas. A sociedade urbana não é pensada como totalidade, tendo na cidade sua materialização. A noção de cidadania perde sua conexão com a idéia de universalidade. Por isso mesmo, surge um novo vocabulário que expressa a nova representação privada da relação entre governo e população que se está construindo: clientela, parceria, consumidor, etc. (DAMIANI, 2009)

O Programa Favela Bairro, que nos parece realizar tais premissas, foi criado pela prefeitura em 1993 e implementado no ano seguinte como parte da política habitacional do município, visando a integração urbanística e social das favelas. A principal meta do Programa Favela Bairro é integrar a favela à cidade, dotando-a de infra-estrutura urbana, serviços, equipamentos públicos e políticas sociais. (PINHEIRO, 2008).

O Favela Bairro contou com US\$ 600 milhões, resultantes de dois contratos assinados com o Banco Interamericano de Desenvolvimento (BID), cada um no valor de US\$ 300 milhões - sendo US\$ 180 milhões do BID e US\$ 120 milhões da Prefeitura. O contrato previa o custo máximo de US\$ 4 mil por família e de US\$ 3.500 na média, ao longo da execução do programa. Acima desse valor previamente estipulado seria necessária aprovação prévia do órgão financiador. Além dos recursos do BID e da Prefeitura, o Programa contou com verbas da Caixa Econômica Federal por meio do Comunidade Solidária e de outros programas, como o Prosanear (CARDOSO e ARAÚJO, 2007)

O Favela-Bairro é considerado um projeto modelo do Banco, um exemplo de políticas públicas no combate à pobreza e à miséria. Atualmente, a Prefeitura já firmou com o BID o terceiro contrato do Programa no valor de US\$ 300 milhões $^{36}$. Foi indicado pela ONU, no

\footnotetext{
${ }^{35}$ No capítulo 4 apresentaremos discordância em relação a esse debate, pois consideramos que a questão fulcral relaciona-se a propriedade privada e sua relação como equivalente de mercadoria.

${ }^{36}$ Veremos no capítulo 3 que os rumos e o marketing dos projetos de urbanização de favelas mudaram. O Programa Favela Bairro deixou de existir e foi substituído pelo Programa Morar Carioca. Amélia Damiani
} 
Relatório de Situação Mundial das Cidades 2006/07, como um exemplo a ser seguido por outros países. Com os termos de uma suposta legalidade jurídica e estatal se constroem contradições substanciais, radicais e aprofundadas: endividamento público (uma das engrenagens do capital fictício, como expõe PAULANI, 2008), relações dependentes e mesmo subservientes do público ao privado, políticas de habitação submetidas à regulação bancária, negação do direito à cidade e a inserção precária dos moradores de favelas.

Randolph (2004: 276) argumenta que

na sua primeira fase, a partir de 1994, o programa tinha como principal missão integrar e solucionar problemas como saneamento básico, drenagem, contenção e serviços sociais. Consolidou-se como Programa de Urbanização de Assentamentos Populares do Rio de Janeiro - PROAP -, instituído pelo Decreto 14.332 de 07/11/1995, que articulava o Programa Favela Bairro (que teve sua base legal estabelecida pelo Decreto 12.994, de 16/06/94) com o Programa de Regularização de Loteamentos, além de tomar outras providências. A parte referente ao "Favela- Bairro" reproduz exatamente os objetivos que constaram nos documentos anteriores. O contrato de empréstimo entre Prefeitura e BID consolidou os recursos necessários para sua execução. Conforme o Anexo A deste contrato, seus três componentes seriam a "urbanização de favelas", a "regularização de loteamentos" e o terceiro componente dividia-se em "(i) monitoramento e avaliação, (ii) educação sanitária e ambiental e (iii) desenvolvimento institucional.

Toda atuação por parte das entidades envolvidas está orientada pelos objetivos, propósitos e componentes do Programa. Em relação a suas metas, o PROAP-RIO (Programa de Urbanização de Assentamentos Populares do Rio de Janeiro) e outros documentos principais (inclusive de elaboração "coletiva" entre as diferentes secretarias da Prefeitura) falam claramente na melhoria das condições de vida, sociais e ambientais, da população de baixa renda do Município do Rio de Janeiro; ou, no máximo, referem-se a comparações entre favela e bairro onde "o bairro" pode ser compreendido como padrão "normal" (standard) da intervenção, tanto em termos objetivos como subjetivos. Aponta como principal meio para o seu alcance o aumento da oferta de infra-estrutura básica e de serviços sociais para a população residente em favelas e loteamento irregulares (RANDOLPH, 2001, 2004).

A contradição entre os interesses do cidadão e das grandes empresas tem sido decidida em favor destas últimas, como se observa sistematicamente na cidade, pois "a prática da modernização cria, no território como um todo, em particular nas cidades, os equipamentos, mas também as normas indispensáveis à operação racional vitoriosa das grandes firmas, em detrimento das empresas menores e da população como um todo" (SANTOS, 1993).

apontou na arguição da presente dissertação de mestrado para o fato da cidade do Rio de Janeiro, a partir da gestão do prefeito Eduardo Paes a "modernização do atraso". 
Na primeira etapa de investimentos do Favela Bairro, a Zona Oeste foi contemplada com apenas um projeto na favela das Três Pontes, o que nos levou a tentar entender tais processos. Em análises, leituras documentais do Programa Favela-Bairro e em trabalhos de campo, nos deparamos com uma espoliação perversa, de inserção precária do proletariado urbano, com urbanizações, sem a realização total ou parcial das obras e sem regularização fundiária das favelas.

\subsection{A ilusão da opacidade}

A ilusão da opacidade, conforme discutido em Soja (1993), reifica o espaço, induzindo a uma miopia que enxerga apenas uma materialidade superficial, formas concretizadas e elementos da paisagem que são passíveis apenas de mensuração e de descrição fenomênica: fixas, mortas e não-dialéticas. Refutar tais aspectos descortina o espaço dito homogêneo, não negando a modernização que impõe um desenvolvimento desigual, por isso não achata completamente as relações sociais.

O movimento de interpretações opacas da problemática urbana materializa-se em três grandes conjuntos de discursos, que serão desenvolvidos a seguir: a opacidade do aparelho do Estado (instituições - IBGE e CEDAE e instrumentos - Plano Diretor e Planejamento Estratégico), a opacidade teórica de parte dos intelectuais e da Academia e a opacidade da mídia, em particular dos meios de comunicação de massa.

\subsubsection{Opacidade do aparelho do Estado: o caso do IBGE}

Alguns conceitos "operacionalizam" as discussões, mas sob categorias "opacas" turvam e distorcem a problemática urbana e a questão social do abastecimento de água. $\mathrm{Ou}$ seja, apresentam um conjunto de nomenclaturas técnicas que escamoteiam e não elucidam a realidade contraditória da sociedade, principalmente em relação a habitação popular. O IBGE, que trabalha com todos os municípios, nunca adotou uma terminologia fechada, mas sim um termo genérico (aglomerados subnormais) como sua definição. Para os planejadores e técnicos administrativos dos anos 1970, as favelas eram caracterizadas como "aglomerados subnormais" (CODESCO, 1970, apud Blank 1980:8), enquanto a cidade representava os aglomerados "normais".

Desta forma se estabelece um tipo de relação dicotômica das favelas com a cidade por meio da qual a cidade é percebida como o locus da civilidade e do moderno, enquanto as favelas são percebidas como o lugar do atraso, da pobreza e da criminalidade em suas 
diversas modalidades. Vale ressaltar que o termo "aglomerado" foi formulado pelo censo realizado pelo IBGE em 1940.

No Censo de 1980, o IBGE ainda exemplificava, para dar conta dos "regionalismos" do território nacional brasileiro (COSTA, 2002b), uma generalização entre "favelas, mocambos, palafitas, malocas etc.”. Já nos Censos de 1991 e 2000, o exemplo de aglomerado subnormal restringiu-se a "favelas" e um vago "e similares". O conceito operacional de "aglomerado subnormal" (favelas e similares) abarca as formas de moradias precárias nas metrópoles brasileiras, achatando a questão urbana:

constituído de, no mínimo, 51 unidades habitacionais (barracos, casas...), ocupando ou tendo ocupado até período recente, terreno de propriedade alheia (pública ou particular) dispostas, em geral, de forma desordenada e densa, bem como carentes, em sua maioria, de serviços públicos essenciais (COSTA, 2002a).

O importante é que, ao menos, os técnicos do IBGE explicam que se trata de um conceito operacional e não um conceito construído a partir de um resultado de pesquisa. Dadas as dificuldades de se realizar o trabalho nestas áreas, foram consideradas como setores “especiais”. Há, inclusive, outros setores especiais, também de caráter operacional: quartéis, alojamentos, embarcações, aldeia, cadeia e asilo que também apresentam as mesmas dificuldades de abordagem em campo.

Ante a tal perspectiva, pode-se questionar qual a importância de tal dado para a análise das políticas de abastecimento de água. O IBGE fala em reformular o conceito de "aglomerados subnormais (com outra denominação, inclusive menos preconceituosa), ampliação das perguntas voltadas para a caracterização da precariedade dos serviços públicos (falta d'água, inundações, riscos etc.) e da irregularidade fundiária." (COSTA, 2002a; 2002b)

A declaração de Costa (2002a) demonstra que o IBGE ainda desconhece em partes tal realidade, reafirmando a possibilidade de reinterpretação dos dados para futuras análises demográficas. Dentre as incertezas consistem os dados acerca do abastecimento de água nas favelas e muitas vezes nas periferias distantes das grandes metrópoles, como no caso do Rio de Janeiro. Kleiman (1996: 26) aponta que no Censo de 1950, o primeiro que traz dados sobre infra-estrutura, encontram-se informações sobre água e eletricidade. Sobre o abastecimento de água indica apenas a existência ou não de rede geral, não captando nenhuma outra forma de abastecimento. O Censo de 1960 repete tal modelo, abordando a existência ou não de uma rede geral de esgotamento. Tratava-se e trata-se até hoje, como assinalam Costa (2002a) e Kleiman (1996), de um parâmetro quantitativo dos dados. Nesses dois censos o parâmetro apresenta como característica a não discriminação da origem da água e a não distinção do 
destino do esgotamento sanitário, mostrando a desarticulação entre os sistemas. A distinção começa a aparecer no Censo de 1970, quando o item abastecimento de água apontava para a existência de rede geral, poço ou nascente. No Censo de 1980 e 1991 a distinção amplia-se com o item canalização interna ou não, possibilitando a análise sobre o abastecimento de água que se realiza a partir de outras formas para além da rede geral e se há água no interior do domicílio ou apenas dentro da propriedade. No Censo de 2000 a questão é: forma de abastecimento de água (rede geral; ou poço ou nascente (na propriedade); e outra) não havendo distinção alguma sobre que outras formas se utilizam os moradores para as deficiências ou inexistência de rede de infra-estrutura de abastecimento de água. Também aparece nestes termos a questão da canalização (canalizada em pelo menos um cômodo, canalizada na propriedade ou terreno; não canalizada).

Uma outra questão que se coloca é: como o resultado do Censo baseia-se na resposta do morador, sendo que na maioria das vezes, este apresenta um estranhamento à dinâmica das redes de infra-estrutura de saneamento e dos mecanismos que o levam a ter água, o morador pode responder de modo inexato ou pouco preciso (nos termos estabelecidos pelo IBGE) sobre a situação de seu domicílio. E quando o entrevistado tem consciência da ausência ou ineficiência do abastecimento não há momento possível para a resposta completa e complexa. Tal panorama indica-nos, baseado em Kleiman (2002) e Randolph (2004), que há um índice elevado de erros nos dados sobre saneamento no Brasil. O percentual de erros deve ser mais elevado em favelas onde o atendimento é mais precário e heterogêneo, e onde a infra-estrutura construída foi auto-construída baseada em ligações clandestinas da rede geral de abastecimento. Essa observação revela o estranhamento e a alienação que existe em relação às técnicas e tecnologias das redes de abastecimento. A contradição que se coloca é que, particularmente nas favelas, a infra-estrutura foi auto-construída em mutirões realizados pelos próprios moradores. A linguagem técnica escamoteia o que a vida cotidiana realiza.

Em suma, Kleiman (1996:28) afirma que os parâmetros do IBGE sobre a rede de infra-estrutura de abastecimento de água expõem que

o indicador disponível tem uma determinação quantitativa, reporta-se ao domicilio e ao individuo. Possui uma lógica de entendimento da infraestrutura como ligação um a um deste domicilio, assinalando somente um acontecimento de engenharia. Ele aponta uma ligação, mas não revela a dimensão do serviço, ou seja, o que ocorre no interior da ligação, se alguma matéria flui, com que regularidade, enfim, sua qualificação.

A Pesquisa Nacional de Saneamento Básico (PNSB) certamente apresenta avanços nos dados sobre a infra-estrutura de saneamento, porém, muitas vezes não consegue observar 
essas questões nas áreas onde o problema é estrutural. É verdade que a criação do Ministério das Cidades foi uma inovação do primeiro mandato do governo Lula, com toda uma nova estrutura operacional - que articula as políticas de habitação, saneamento, transportes e desenvolvimento urbano, e com importantes melhorias nas questões formuladas na PNSB. Porém, o Ministério das Cidades foi eclipsado pela barganha político-eleitoral sendo encapsulado em políticas que reforçam as contradições e as relações entre capital financeiroimobiliário (e outras frações da classe burguesa) e o aparelho do Estado.

Em suma, os dados censitários são os únicos que às vezes se tem acesso, e quando há, os próprios técnicos do IBGE questionam sua viabilidade analítica (COSTA, 2000, 2002a, 2002b).

Apenas com os dados censitários, quando da indisponibilidade (ou incerteza) de dados das Pesquisas Nacionais de Saneamento Básico, não se sabe a frequiência do abastecimento durante o dia, a intermitência durante as semanas e os meses e a qualidade da água desse sistema (se é de boa qualidade, ou se apesar do abastecimento "regular" necessita-se de outra fonte para a manutenção da vida), se nesse setor censitário (definição de área de estudo que o IBGE realiza) há racionamento de água ou se mesmo abastecidos pela rede geral, sua vazão é insuficiente, ou mesmo se com a água se mantém costumes e tradições que não se conectam com a lógica econômica da mercadoria-água e suas redes. Opacifica-se a questão nestes termos: há abastecimento de água, sim ou não; há canalização, sim ou não. Carlos (2008) analisa que a produção da vida não envolve apenas a reprodução de bens para a satisfação das necessidades materiais, sendo também a produção da humanidade do homem.

\subsubsection{Opacidade do aparelho de Estado: o caso da CEDAE}

Conforme estudos de Marques (1993, 1995, 1998, 2000), podemos observar a opacidade da CEDAE. Na década de 1970 a CEDAE começou a realizar algumas intervenções urbanas nas periferias da cidade do Rio de Janeiro e da metrópole fluminense, ocorrendo uma melhoria dos indicadores na cobertura e das condições de vida e de saúde (MARQUES, 1998, 2000) do proletariado urbano. Como argumenta Bueno (2000), no final da década de 1960 e início da década de 1970, Rio de Janeiro e Belo Horizonte foram as duas cidades que realizaram ações de dotação de infra-estrutura principalmente de energia elétrica e posteriormente de abastecimento de água. Alguns motivos para essas mudanças podem ser brevemente sintetizados: intensas lutas pela urbanização de favelas como bandeira política e atuações dos movimentos de bairros e da Federação de Favelas da Guanabara (FAFEG) e posteriormente do Rio de Janeiro (FAFERJ), a possibilidade técnica de construção de redes 
que não necessitam de escavações no solo, caso da eletricidade (com a construção de redes aéreas) e da mudança de um paradigma político-ideológico até então consolidado (fruto de muitas pressões políticas dos movimentos sociais) de que a favela não deveria receber serviços e infra-estrutura urbana. Ressalta-se porém que particularmente na Zona Oeste, e especialmente sobre a questão do abastecimento de água (com as bicas d'água) ocorre a manutenção de um poder local com interesses de realizar o clientelismo para a reafirmação de seu poder e prestígio político (LOPES, 2007). As elites realizam através da distribuição de água uma reafirmação de poder e domínio sobre a produção do espaço, como observou por exemplo Mike Davis (2009) no caso da Califórnia nos Estados Unidos.

Para Bueno (2000), outra modificação de ordem técnica que transformou substancialmente a distribuição de água principalmente para as favelas foi a descoberta do tubo de polietileno flexível (PEAD) para a distribuição de água. A autora relata que no final da década de 1970, engenheiros e sanitaristas que trabalhavam nas empresas estatais de saneamento procuraram buscar soluções para melhorias sanitárias das favelas e conseguiram um meio de introduzir o abastecimento de água com o uso do PEAD. Essa tubulação, por ser flexível, permitiu a execução de uma rede sinuosa e de pequena profundidade, e possibilitou, por exemplo, políticas de saneamento para as favelas durante a década de 1980. Todavia, a questão do abastecimento de água aparece descolada dos outros componentes do saneamento, como os problemas de esgotamento sanitário, drenagem e coletas de resíduos sólidos que não acompanham a implementação de abastecimento de água.

As condições, apesar de mais satisfatórias, continuaram precárias por duas razões. Em primeiro lugar porque esses foram os primeiros investimentos a alcançar tais espaços, não conseguindo fazer frente à grande "demanda acumulada", ao contrário dos espaços não periféricos, que já vinham recebendo equipamentos há muito tempo e apresentavam elevado estoque de infra-estrutura (MARQUES, 2000: 285). Nas imensas favelas e nas periferias foram autoconstruídas, não somente a habitação, mas boa parte das infra-estruturas urbanas. Esse argumento é central na análise de Marques (1993) e também em momentos de reflexões de Kleiman (1996) e Britto (2002).

Em segundo lugar, a efetividade dos investimentos realizados na periferia foi - e ainda é - muito menor que os realizados nas áreas habitadas pelas classes sociais mais abastadas, sendo de pior qualidade os equipamentos, as obras e os serviços.

Além da fiscalização ter sido realizada de forma precária, os sistemas quase sempre foram incompletos e a operação e manutenção menos cuidadosas. Isso se deve a duas dimensões inter-relacionadas. Primeiramente, no enquadramento organizacional das políticas para tais regiões da cidade, os 
programas que são integrados como rotina institucional na empresa tendem a receber recursos de forma continuada, constituir burocracias sólidas e procedimentos administrativos e técnicos apropriados, enquanto os programas (e regiões) integrados à política de forma esporádica. - como a Baixada Fluminense, as favelas e a periferia do município do Rio de Janeiro tendem a ter intervenções descontinuadas e de pior qualidade. (MARQUES, 2000: 285)

Junta-se a isso o fato de a maioria dos técnicos da CEDAE ter uma visão fortemente hierárquica do setor, da política e da sociedade, além de não se identificarem com tais espaços (MARQUES, 2000). Como conseqüência, quase sempre se considera que os espaços periféricos podem (ou mesmo devem) ser atendidos depois e com qualidade inferior. Essa dimensão da cultura técnica do setor (MARQUES, 2000) não é combatida, mas ao contrário, reforçada pelo enquadramento organizacional das políticas para essas áreas.

Estabelece-se um padrão regressivo no que tange a questão do saneamento: as áreas mais valorizadas pelo capital financeiro-imobiliário e pelo modo especulativo de valorização do espaço recebem infra-estrutura e renovam suas redes, enquanto as áreas mais pobres, onde não existe tal valorização, são providas depois, quando os são, com qualidade de serviços duvidosa.

De acordo com a CEDAE, segundo dados apresentados por Marques (2000: 286), a cobertura de esgoto da capital é de 95\%. Mas, neste percentual, não está incluída a Zona Oeste (48\% da área da cidade e onde vivem 30\% dos cariocas) nem as favelas (ao todo, 1.026, onde mora $20 \%$ da população). Fica de fora, por exemplo, o Morro da Fé, na Penha, Zona Norte da cidade, onde a rede de esgoto só chega às ruas de acesso à comunidade. Também, as favelas ao lado da favela Três Pontes ("urbanizada" pelo Programa Favela Bairro), exemplarmente a favela do Paraguai, na qual a utilização de bicas de água é sua fonte principal de abastecimento. Nesse caso, somente a favela das Três Pontes recebeu investimentos em abastecimento de água, e em algumas partes da favela, enquanto seu entorno permaneceu amplamente desprovido.

Assim, a questão da água parece estar resolvida no discurso oficial. Conforme aponta Cavallieri (2009) a cobertura do abastecimento d'água (que segundo o autor caracteriza-se em “domicílios ligados a uma rede geral” percebe-se já a ilusão da opacidade) aproxima-se do universo, alcançando em 2000 quase 97\%. Para o aparelho do Estado, as políticas públicas devem se focar em outras questões, pois essa questão lhes parece resolvida. Vejamos essa questão no Plano Diretor e no Planejamento Estratégico. 


\subsubsection{Opacidade do aparelho de Estado: o caso do Plano Diretor e do Planejamento Estratégico}

As administrações públicas têm priorizado o superdimensionamento da "visibilidade" de determinados projetos, obscurecendo e simplificando não apenas antigas e críticas questões urbanas, mas também a "necessidade" de se investir em políticas públicas direcionadas à efetiva demanda social (MACHADO, 2007). Diríamos que a visibilidade e a necessidade de tais políticas (na realidade uma ilusão de transparência) se referencia dialeticamente na ilusão da opacidade. Na cidade, o "empreendedorismo urbano" promove a modernização espacial como condição da realização da economia mundializada (CARLOS, 2008), e a própria cidade torna-se mercadoria e fonte de lucro com o aumento dos investimentos privados. A cidade aparece como uma marca a ser vendida e valorizada numa sociedade do consumo em que a aparência e a forma abstrata são reificadas (ARANTES, 2010).

Assistimos a emergência e consolidação de um discurso tornado hegemônico, baseado na construção social de uma "imagem urbana dinâmica e competitiva" (ARANTES, 2007) direcionada aos mecanismos do city marketing (SANCHEZ, 2003) e do espetáculo, isto é, a cidade voltada para interesses que reverberam em demandas de preparação do espaço urbano ao mercado econômico internacional, ocorrendo conflitos entre os espaço-tempos da reprodução econômica e financeira e da reprodução da vida. Sob tal perspectiva, constatamos importantes desdobramentos que emergem no âmbito dessas considerações.

Um dos exemplos é como se encaminhou a revisão do Plano Diretor da cidade do Rio de Janeiro, nos dispositivos e mecanismos incluídos no chamado Substitutivo 3 - documento que substancia o processo de revisão que vem sendo construído a partir do ano de 2001. Esse documento contém cerca de 1700 sugestões, emendas e subemendas e sua aprovação está ocasionando uma série de conflitos entre os movimentos sociais, as incorporadoras imobiliárias, as grandes construtoras e empresas, nas disputas entre os trabalhadores e os capitalistas e mesmo entre os próprios capitalistas ${ }^{37}$. Nossa análise tomou como base o Projeto de Lei Complementar n ${ }^{\circ}$ 25/2001 (2009) e as considerações desenvolvidas por Nunes (2010).

No processo de construção da imagem urbana mundializada do Rio de Janeiro, a política de intervenções sistemática nas favelas é um dos exemplos categóricos dessa produção do espaço fundada na reprodução ampliada do capital.

As políticas para as favelas baseiam-se na contenção do crescimento, ou seja, na contenção de sua possível expansão (NUNES, 2010), a partir, por exemplo, da construção de

\footnotetext{
${ }^{37}$ Marx (1985) novamente nos parece ter razão, pois a partilha da mais valia absoluta faz com que os capitalistas se degladiem tendo em vista abocanhar cada vez mais uma fração maior desse montante.
} 
muros, que na verdade constituem um apartheid social da favela. Esses muros aparecem sob diversos eufemismos e metáforas, como a criação de ecolimites para a "proteção da vegetação" e para "proteger os moradores das favelas da poluição sonora", tal como se construiu em favelas próximas ao Aeroporto Internacional Tom Jobim (Galeão), principal porta de entrada do turismo internacional na cidade. As propostas de políticas publicas, e que já se transformam em intervenções, são a remoção e o chamado reassentamento da população (PROJETO DE LEI COMPLEMENTAR nº 25/2001, 2009) e mesmo a erradicação da favela, transferindo a totalidade de seus moradores para locais distantes de suas origens. Para os que ficam, resta a regularização fundiária (e os interesses na titulação da propriedade e da posse com as possíveis compras de suas moradias a partir da pressão e/ou valorização de seus imóveis, principalmente na Zona Sul da cidade do Rio de Janeiro) seguida de regularização urbanística, estabelecendo parâmetros e normas para um rigoroso controle e paralisação das ocupações da "população consentida" a permanecer (NUNES, 2010).

Outro exemplo de "visibilidade" e construção de "necessidades", inerente à determinadas políticas públicas, são as políticas de construção de infra-estrutura, serviços e redes de saneamento . As redes de saneamento, principalmente a água, foi e ainda é manejada para angariar votos e garantir a manutenção das elites locais. Por outro lado, o esgoto e a drenagem fluvial, infra-estruturas caras e de retorno político menos visível e imediato, não foram alvos de políticas consistentes. Quando orientamos o foco de nossa análise à questão da infra-estrutura de saneamento, observamos de forma clara e recorrente que embora esteja presente nas discussões sobre o planejamento estatal, o referido tema está longe de adquirir centralidade (quando mencionado, aparece relacionado à "ausência de planejamento e a “desordem da ocupação"), ou ainda de concretizar-se sob a forma de projetos de intervenção efetivos, posto tratar-se de uma rede subterrânea, o que a torna, não raro, "invisível" do ponto de vista físico-material aos olhos da maior parte da população e dos agentes que realizam investimentos na cidade (MACHADO, 2007).

Com a realização dos Jogos Panamericanos em 2007, e atualmente com a preparação da cidade do Rio de Janeiro para sediar a final da Copa do Mundo de 2014 e as Olimpíadas de 2016, a questão ambiental aparece com toda a força de seus fetichismos, magias, metáforas e telescopagens, inserindo a pauta do saneamento, não por acaso ambiental, como um de seus vetores. A infra-estrutura de saneamento se apresenta como pauta no âmbito do planejamento estratégico, momento-movimento de reificação do discurso tecnocrático de gestão empresarial com princípios orientados nas operações urbanas e nas parcerias público-privado tornado cartilha e doutrina. O saneamento, embora considerado uma infra-estrutura pública essencial, 
inclusive no que concerne à saúde preventiva, condição sine qua non para uma vida urbana digna, quase sempre esteve à margem dos investimentos em infra-estrutura urbana (MACHADO, 2007), principalmente devido a quatro aspectos: a inexpressiva "visibilidade" no tecido urbano; a água observada como bem abundante e não escasso - o que ocasiona a não-realização da lei da oferta e da procura, e a raridade da água em sua aparência de crise ecológica que vai possibilitar sua realização como mercadoria; a utilização do abastecimento de água como política clientelista de votos, portanto paliativa e localizada principalmente na conhecida política da bica d'água; e a imagem altamente negativa (principalmente o esgotamento sanitário associado à sujeira, a odores desagradáveis etc.), o que implica em uma baixa capacidade de retorno financeiro para as instâncias governamentais, em especial por meio de divulgação, propaganda e marketing (MACHADO, 2007). Todavia, atrelado à questão ambiental, o saneamento ganha o "selo de qualidade" do mercado, afinal, o padrão ambientalmente sustentável se apresenta como um dos novos signos de modernidade e do desenvolvimento desigual das cidades e das metrópoles no capitalismo.

Fundamentalmente, ressalta-se que tais "estratégias" se concentram na despoluição da Baía da Guanabara, da Lagoa Rodrigo de Freitas e das lagoas de Jacarepaguá - obras que segundo o aparelho do Estado asseguram melhorias da cidade para toda a população residente. Os investimentos em água e esgoto, no âmbito do Planejamento Estratégico lançado em 2009 concentram-se: 1) no Recreio dos Bandeirantes e na Barra da Tijuca, 2) na preparação da infra-estrutura ambiental para os Jogos Olímpicos, 3) na pauta de melhoria ambiental para uma cidade mais saudável e 4) na construção de redes de esgotamento sanitário na Zona Oeste da cidade, fortemente atrelado à melhorias das condições de saneamento para as indústrias se instalarem no distrito industrial de Santa Cruz e adquirirem o "selo verde" de satisfatórias condições ambientais. $\mathrm{O}$ abastecimento de água não é exposto em momento algum. Pode-se depreender que para o aparelho de Estado a questão está resolvida.

E com qual intencionalidade?

Como a questão do abastecimento de água aparentemente está resolvido, encontra-se a possibilidade de realização e efetivação de um negócio que busque uma melhor qualidade de gestão e que não deva/não precise arcar com os custos de implantação de infra-estrutura. $\mathrm{Ou}$ seja, como aparentemente o problema não existe, não é necessário o investimento de um volume de recursos para novas instalações e a recuperação de infra-estrutura de abastecimento de água. Obviamente, as periferias são os territórios que mais sentirão os efeitos perversos dessa negligência. 
Obras de intervenções em saneamento na Proposta de Revisão do Plano Diretor (2009)

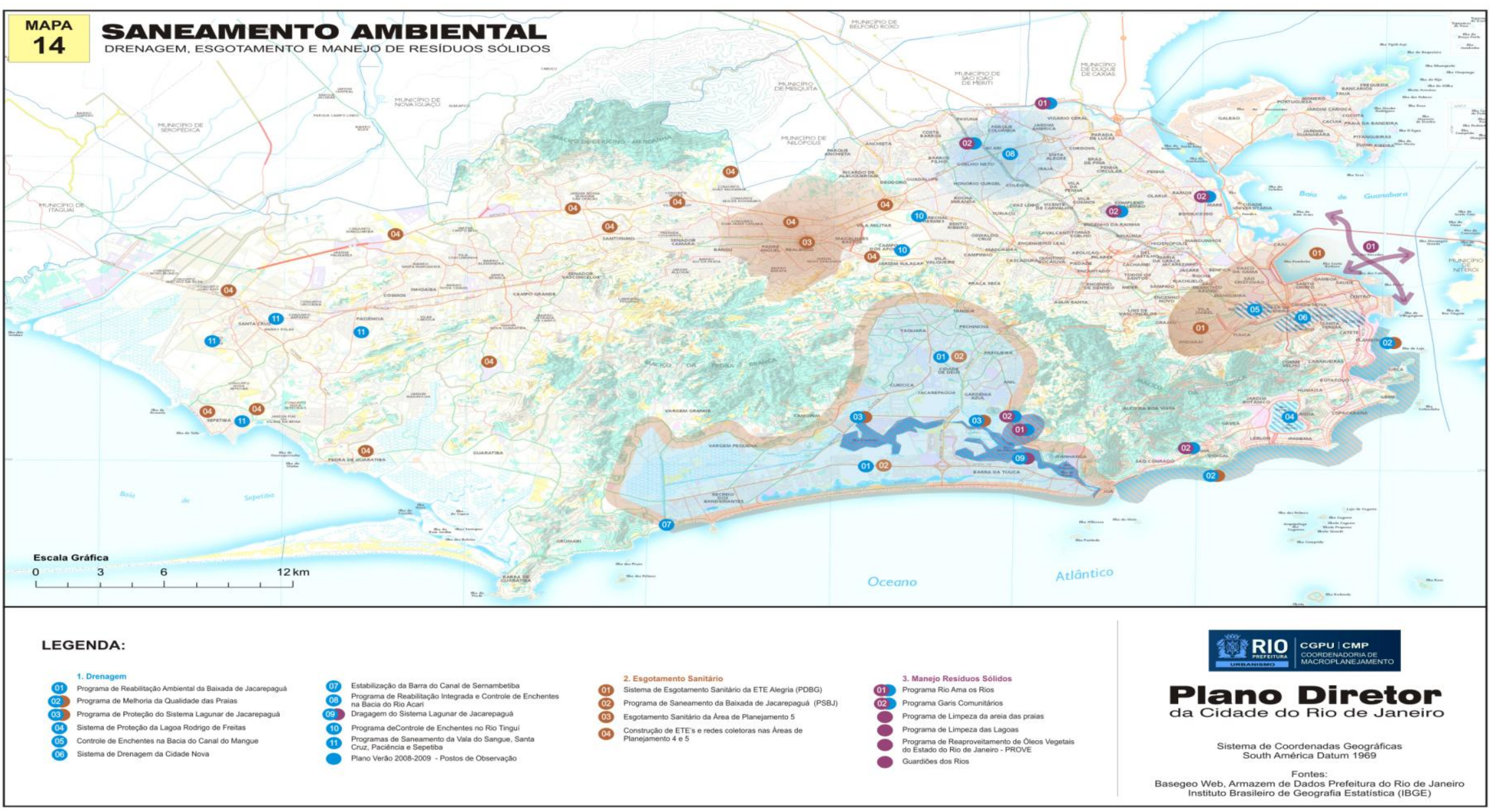

Fonte: Proposta de Revisão do Plano Diretor, 2009

Mapa 4: Obras de intervenções em saneamento na cidade do Rio de Janeiro 
A elaboração do Plano Estratégico da Cidade do Rio de Janeiro em 1995 simbolizou categoricamente a inserção da metrópole carioca no modelo de "gestão estratégica das cidades" (VAINER, 2007), com base na competitividade e no empreendedorismo, assentada na financeirização das relações de produção como ordem racional e logicamente competente. O discurso associado a slogans como "fortalecimento da identidade local", "cidadania", "resgate da auto-estima carioca", entre outros, legitima-se, sobretudo, por uma exaltação espetacular no que tange à atração de investimentos externos, notadamente por intermédio de empresas, pelo incremento do turismo e, ainda, pela realização de grandes eventos. Nesse sentido, substancia-se esse discurso como possibilidade e também a dependência do crescimento e do desenvolvimento econômico numa racionalidade técnico-burocrática.

O reforço de tais paradigmas se consolida no Plano Estratégico da Cidade do Rio de Janeiro (PECRJ) lançado em 2009, e perpassa necessariamente pela questão da infra-estrutura urbana. O governo do prefeito Eduardo Paes, mesmo revisando o Plano Diretor, admite que utilizará o PECRJ como norteador de sua política de resultados e seu choque de gestão. Neste contexto, como afirma Machado (2007) há uma forte tendência de se privilegiar as redes viárias e de telecomunicações, não apenas pela atual fase do capitalismo, na qual é preciso adequar-se aos processos de redefiniç̧ão dos padrões que comandam as relações sociais de produção e apropriação do espaço - que priorizam a circulação de bens, serviços, informações e mercadorias - mas, também pelo fato de que investimentos realizados nas referidas redes de infra-estrutura são importantes para a construção e consolidação de uma imagem urbana moderna e competitiva.

Um dos movimentos de interpretação da urbanização crítica proposto por Damiani (2009) é o da profunda destituição da humanidade do homem e, ao mesmo tempo, a "naturalização" do humano. Há uma exaltação da natureza e do natural, preenchendo o vazio de projetos políticos de superação de inúmeras crises sociais. A potência ideológica do ambiental, substituindo o "caos sócio-espacial" é extremamente paradoxal, como analisa a autora. Uma das diretrizes da chamada "ordem pública" da cidade do Rio de Janeiro explicitada no Planejamento Estratégico é a diretriz de "coibir novas ocupações ilegais e a expansão horizontal ou vertical das comunidades estabelecidas, a partir do uso efetivo de ecolimites e de um monitoramento aerofotográfico constante", isto é, apartar a favela impondo a construção de muros para o cercamento da mesma (BURGOS, 2009).

Os paradigmas de implementação de tais processos são o planejamento estratégico (conforme analisado) e a urbanização consorciada. Esta baseia-se no Estado, que faz 
concessões à iniciativa privada mediante o oferecimento de contrapartida por parte do empreendedor interessado, isto é, as famigeradas parcerias público-privadas.

\begin{abstract}
SEÇÃO IX - DA URBANIZAÇÃO CONSORCIADA Art. 72. A urbanização consorciada será utilizada em empreendimentos conjuntos de iniciativa privada e dos poderes públicos federal, estadual e/ou municipal, sob a coordenação deste último, visando à integração e à divisão de competências e recursos para a execução de projetos e obras específicos, com a participação de recursos privados obtidos através de contrapartidas dos proprietários, de consórcios ou da aplicação dos instrumentos de gestão do uso e ocupação do solo (...)Art. 73. Poderão ser objeto de urbanização consorciada, as áreas parceladas e ocupadas irregularmente, sem as obras de urbanização previstas em lei e com inobservância às normas de proteção ambiental, que apresentam malha urbana desarticulada e deficiência de infraestrutura, carência de serviços públicos e de áreas públicas destinadas a equipamentos urbanos. (RIO DE JANEIRO, 2001: 30)
\end{abstract}

Articulado a esses pressupostos de análise, Cardoso e Ribeiro (1994) dissertam que há a emergência de um paradigma ambiental articulado ao pensamento neoliberal que estabelece a delimitação de novos marcos de "atuação" e "gestão" das cidades: problemas (e não questões), novas técnicas instrumentais de ação e novas escalas de articulação.

A natureza social do mundo e de suas relações é subsumida pela naturalização dos processos sociais (SEABRA, 1987; 2003), a sociedade (achatada como um vetor de problemas ambientais e retratada como ação antrópica) deixa de ser a base da legitimação de discursos e ações, descola-se os conflitos de classes e a humanização do homem da relação entre homem e natureza, sendo (im)posto às relações sociais o corolário do "ambientalismo" (SEABRA, 2003; CARDOSO e RIBEIRO, 1994).

Incorporam-se idéias de participação (formalmente burocrática), autonomia local (constantemente baseado no desenvolvimento comunitário local, telescopagem da mundialização do capital e na economização do urbano baseado no indivíduo autonomizado) e desregulamentação (oportunidade para as empresas privadas exercerem as parcerias público-privadas).

Nessa atmosfera, os princípios do Banco Interamericano de Desenvolvimento para a gestão "dos recursos hídricos" são:

conservar agua mediante la asignación más común en los dos extremos: resolver conflictos entre usos y usuarios que compiten tener en cuenta el valor social, económico y ambiental del agua; aumentar la participación de las comunidades y del sector privado en la adopción de presenta es que la utilización de los recursos hídricos decisiones y en la financiación. La prestación de servicios de agua generalmente está centralizada en organismos y organizaciones de gobierno que suelen tener demasiadas funciones, no disponen de fondos suficientes y estan mal organizadas para prestar servicios de calidad, lo que resulta, por ejemplo, en el deterioro de la infraestructura y una baja eficiencia. Tradicionalmente se ha optado por una 
solución reguladora en vez de criterios basados en el mercado o em incentivos de otra índole. Los cambios en el manejo han tenido lugar en su mayor parte por conducto del gobierno centralizado y sin participación de los entes interesados (BANCO INTERAMERICANO DE DESARROLLO, 1998: 2).

A sociedade passa a ser considerada como mero instrumento, como se não existissem sujeitos históricos, inserida dentro de um "ecossistema", naturalizando processos sociais (SEABRA, 2003) no qual os homens são incluídos (CARDOSO e RIBEIRO, 1994) como uma coleção de atores.

Ao Estado-nação cabem os planos da gerência dos impostos e das dívidas públicas e, claro, a criação de um mercado no qual as perspectivas neoclássicas de atores racionais e regulação do mercado possam se desenvolver livremente. Ao Estado cabe ainda salvaguardar os investimentos de capitais quando das profundas crises ainda mais recorrentes do capitalismo. Para Seabra (2009), as políticas públicas de Estado são o corpus de práticas e normatizações políticas que perpassam a vida social de cima para baixo. O planeta e a escala local de intervenção passam as ser as novas mediações da ação coletiva (consubstanciadas nas idéias de sociedade civil e desenvolvimento local) ${ }^{38}$. A cidade torna-se um ator da competição entre cidades, e a "participação da comunidade" é cada vez mais cooptada nos debates. Por fim, o planeta é o vir-a-ser, o lugar a ser preservado para as futuras gerações, escamoteando as alienações, estranhamentos e ocultamentos das classes sociais. Também, a discussão acerca das classes sociais metamorfoseia-se num fetichismo do espaço localizacional e taxonômico. Assim, não é fortuita a criação de conceitos como: bolsões de pobreza, linhas de miséria, territórios da ilegalidade, etc. A instrumentalização do espaço a partir da forma é um momento paradigmático de veiculação e reafirmação da sociedade de classes e da propriedade privada.

\subsubsection{Opacidade teórica: cidade partida, urbanização desordenada e a "renovação" (do mito) da marginalidade}

Assim, o que constatamos em discussões teóricas "opacas" são centralizações no debate sobre a questão urbana, sobretudo balizada em termos/conceitos como "desordem" e "ilegalidade". O debate acadêmico no Brasil acerca do "urbano", para alguns autores, gira em

\footnotetext{
${ }^{38}$ No momento da mundialização do capital, Francisco de Oliveira (2010) denuncia a "cristalização" de uma conceituação apaziguadora de sociedade civil e de desenvolvimento local. Ressalta que a sociedade civil não se reduz simplesmente ao conjunto de atores privados. No momento atual do modo de produção capitalista se sobrepõe o discurso das organizações não governamentais, que apresentam a sociedade civil como o lugar do não-conflito.
} 
torno do tema da expansão urbana, expressa, por exemplo, nos processos de favelização e de loteamentos nas metrópoles. Todavia, o conceito de ilegalidade urbana é um dos parâmetros centrais na definição das clivagens sociais, econômicas, espaciais e políticas postas em discussão, conforme expõem Lago (2003); Valladares (2006); Telles (2009). A visão dualista da realidade urbana apresenta-se com toda sua força podendo se expressar através de diferentes dicotomias, tais como formal-informal, incluído-excluído, favela-bairro, integradopartido, sendo que em todas a (i)legalidade está presente como um dos critérios diferenciadores, conforme apontam Lago (2003) e Lago e Ribeiro (2001).

Constrói-se a representação da favela como "território da violência, como lugar de todas as ilegalidades, como bolsão da pobreza e da exclusão social", fazendo circular as imagens da fratura social e de uma "cidade partida" (VALLADARES, 2006:20). É sob essa perspectiva que Valladares $(2000 ; 2006)$ critica autores que constroem suas análises na associação quase exclusiva entre violência urbana/segregação socioespacial e favela/pobreza, fazendo dessa relação a própria especificidade e definição da favela, e também uma "suposta especificidade carioca".

Um conjunto de pressuposições marca a produção acadêmica recente, segundo expõe Valladares (2006). A autora expõe que supostos e pressupostos pouco debatidos estruturam consensos, que pautam a agenda intelectual e política e conformam um campo de pesquisa que deixa escapar, sob uma figuração homogeinizadora da favela, uma diversidade social e espacial em seu universo, bem como o dinamismo social e econômico que vem substanciando esses fragmentos da cidade.

Porém, compreendemos que uma visão historicista sobre a favela é também absolutamente problemática, pois essas análises tomam cada favela como um ente único e a partir de suas peculiaridades atinge-se uma totalidade fechada de análise. Percebemos, ainda, como problema da visão historicista não encarar que no particular há uma relação dialética com a totalidade, e que no concreto há a síntese de múltiplas determinações. As especificidades são momentos para a compreensão da totalidade.

As particularidades de cada favela conectam-se à questão urbana e à problemática da produção do espaço e não podem ser compreendidas como uma espécie de "alquimia" como critica Telles (2009) em que se fundem irregularidade da ocupação do espaço urbano e ilegalidades relacionadas ao mundo do trabalho, pobreza, privações de consumo de mercadorias, manifestações culturais que lhe dariam a marca de identidade, como o samba em outros tempos e funk atual, no caso do Rio de Janeiro (OLIVEIRA e MARCIER, 2006), além da criminalidade, violência e tráfico de drogas. Esses problemas podem e devem ser 
compreendidos em seus inúmeros pormenores, porém são aparências de problemas estruturais da sociedade. Outros conceitos que opacificam o debate teórico e achatam a realidade nas considerações sobre a favela são: "cidade dentro da cidade", "enclave" e "território da partição", símbolo da segregação socioespacial (TELLES, 2009). Projeta-se sobre a favela um corolário que nos parece mais uma doutrina em que desloca-se teoria e prática, negligenciando as evidências de uma realidade contraditória, realizada em múltiplas determinações. A aparência e as forma da favela são autonomizadas, a relação entre aparência e essência negligenciada.

Assim, produzem-se "conceitos" que explicitam não uma potência na tentativa de explicação da situação crítica da sociedade, mas um desconhecimento sobre a realidade das favelas, da divisão do trabalho, da cidade e do urbano e dos processos de urbanização. Uma das grandes contradições da cidade capitalista encontra-se na relação entre investimento público e apropriação privada. Exemplarmente, a valorização de um imóvel é determinada por investimentos públicos, e o lucro obtido dessa valorização é auferido individualmente pelo empreendedor ou proprietário (FERREIRA, 2010). No Brasil, os investimentos públicos em infra-estrutura foram claramente direcionados e concentrados nas áreas ocupadas pelas classes sociais de alta renda (OLIVEIRA, 1978; MARICATO, 1979; MARICATO, 2007). O Estado deliberadamente e de modo competente reforça os padrões violentos de segregação sócioespacial, definindo os fragmentos do espaço das classes sociais. Oliveira (1978) argumenta que a alternativa de moradia que melhor permitia a manutenção do baixo custo da força de trabalho era a auto-construção na periferia das metrópoles. Desse processo resultam áreas densamente dotadas de investimentos públicos e de infra-estrutura e serviços urbanos, e contraditoriamente fragmentos do espaço desprovidos ou precariamente servidos de infraestrutura disponibilizada pelo Estado. Nessas periferias, os moradores se oneravam (e ainda se oneram) empenhando uma parte de seus salários para a auto-construção de suas moradias e infra-estruturas, e também empenham uma parte de seu tempo livre para a realização dessas construções.

Consideramos que as questões e os conceitos sobre o urbano e a urbanização estão sendo colocados de maneira equivocada. Não se responde as perguntas sobre as questões urbanas submetendo-as ao "urbanismo de mercado" centrado no "planejamento estratégico" da cidade de oportunidades, ao planejamento urbano submetido à tecnocracia e aos ditames do capital financeiro-imobiliário, nem considerando o Estado incompetente na "resolução dos problemas". Pois, desse modo, a aparência da forma ganha estatuto de totalidade, e a abstração se eleva ao concreto. 
O objetivo e o resultado dos conceitos que opacificam a produção do espaço urbano são a superação positiva dos problemas via intervenção estatal, ou seja, um planejamento mais eficaz resolveria os problemas, e quando o Estado não "consegue" responder às "demandas", as parcerias público-privadas seriam a saída, a salvação. Esse aparato conceitual produzido na Academia é projetado e propagado sob o intermédio dos meios de comunicação de massa. Vejamos alguns conceitos mais de perto.

Parece-nos que aquilo que Perlman (1979) afirmava como mito da marginalidade se renova, como defende Fernandes (2009). A autora aponta os principais fatores de marginalização: 1. Localização (território); 2. Situação na escala socioocupacional (classe); 3. Migrantes ou membros de subculturas; 4. Minorias raciais (cor) e étnicas; 5. Transviados. Perlman (1979:26) vê a estigmatização territorial gerando "uma marginalidade que isola o gueto ou a favela como um espaço fisicamente delimitado, dentro do qual todo mundo é marginal, e fora do qual todo mundo é mais ou menos integrado"; ou seja, cria-se uma imagem durkheimiana (VIEIRA, 2004), onde o território marginal seria uma anomalia dentro de um todo coeso e estruturado. Enfim, haveria a necessidade de reintegração deste fragmento à sociedade (FERNANDES, 2009).

Há ainda a opacidade conceitual da discussão acerca da "cidade partida" numa fecunda interlocução com as ponderações já expostas. O equívoco fundamental dessa visão sociocêntrica, referenciada nos setores médios da cidade e massificada pelos meios de comunicação, é considerar que as distinções espacial, econômica e cultural, manifestas na demarcação de territórios dos diversos grupos sociais residentes na cidade, são suficientes para esfacelar a cidade (SILVA, 2006). Para Silva (2006) não é partida uma cidade que construiu e constrói os vínculos históricos, econômicos, políticos, culturais existentes no Rio de Janeiro; onde se manifesta uma rica circularidade dos grupos sociais, em particular o proletariado pauperizado. Essa dinâmica histórica gerou uma "cidade plural", decorrente das variadas formas de encontros e distâncias estabelecidas no cotidiano dos cariocas. $\mathrm{O}$ fato dos setores que habitam os espaços "formais" não a perceberem, de forma ampliada, não impede que ela exista (SILVA, 2006; BARBOSA e SILVA, 2009). Porém, não corroboramos com essa visão. Observamos tal como Seabra (2009) que no processo de concentração, implicado nos processos e transformações urbanas, está calcado o aprofundamento crescente da divisão do trabalho e na difusão do dinheiro como mediador fundamental das relações. Não na lógica na cidade partida, mas também não numa visão pluralista e culturalista da cidade.

Devido a tais acúmulos, a estrutura normativa que Seabra (2009) critica se realiza na abstração do direito, ou seja, no que consideramos ser representado em partes pelos meandros 
da justiça: aparato judicial (juristas, advogados) leis, mandatos judiciais, constituição, aparato repressivo do Estado, e o próprio Estado político que aliena e submete a sociedade civil ${ }^{39}$ (MARX, 2005). Esta abstração representa a manutenção do status quo, ou a manutenção constitucional e jurídica da barbárie capitalista (PRIETO e VERDI, 2009) e o esgarçamento ainda maior entre as classes dominantes e a classe trabalhadora. Além da estrutura normativa, Seabra (2009) argumenta também que as estruturas materiais nas edificações e construções passam a não comportar a magnitude do urbano em processo de concentração. Dessa maneira, a quantidade vence a qualidade e a partir de um certo momento, a autodestruição da cidade torna-se evidente (SEABRA, 2009). Esse processo expressa mais uma aparência da crise estrutural do capital, porém não é encarado pelos capitalistas como barreira: a auto-destruição da cidade torna-se uma oportunidade de negócio urbano, pois pouco importa ao capitalista a mercadoria a ser trocada, mas a sua condição de reprodução ampliada. Esse movimento reafirma nosso pressuposto fundamentado em Marx (1985) do capital como limite de si, que vai estabelecer os limites de sua expansão como se fosse externo a ele. Assim, a crise urbana, a crise ambiental, a crise financeira, etc. são manifestações dos problemas que devem ser resolvidos em si, caso essas crises se transformem em oportunidade de realização de sobrelucro, ao invés de custos se obterem ganhos. As manifestações da crise somente são momentos de mudança de paradigmas quando são danosas às engrenagens da reprodução.

Assim como Seabra (2009:6), consideramos também que podemos afirmar que a metrópole apresenta uma aparência real do "reino da quantidade: grandes números, sociedade de massas, grandes espetáculos, grandes orçamentos, estádios superlotados... Que é, sobretudo, o reino do valor de troca, que se reproduz numa situação crítica".

Consideramos, articuladamente a esse debate, que a urbanização nos termos de sua reprodução na moderna sociedade produtora de mercadorias, fundada na formação econômico-social capitalista, não equivale na produção do urbano para todos. É sim a impossibilidade do urbano para todos, como já destacamos. A concepção de "urbanização desordenada" (a apoteose desse conjunto de discursos) sugere a possibilidade de planificação, fundada em uma racionalidade técnica competente, que não decifra o cerne dos problemas, não compondo uma crítica radical dos mesmos. Há uma racionalidade engendrando os fios dessa crise: o urbano transformado em mercadoria (DAMIANI, 2010). Reforça-se a imagem dos proletários como os responsáveis por sua condição de pobreza. Suas moradias e infraestruturas auto-construídas são frutos desse discurso da "marginalidade", da "cidade partida"

\footnotetext{
39 Retornaremos a esse debate dando-lhe outros contornos no capitulo 4, A mercadoria água e seus segredos.
} 
baseada na desordem da produção de seus espaços. O olhar permanece centrado no equívoco da construção da sua cidade e de seu urbano desordenado. O Estado e o mercado estabelecem uma urbanização imposta e centrada na resolução paliativa das questões.

\subsubsection{A opacidade da interpretação da mídia.}

A utilização freqüente pela mídia de metáforas como "cidade partida", "desordem urbana", "urbanização desordenada" entre outras, por um lado, vem dotando a concepção dualista da favela centrada na legitimidade social. Por outro lado, emergem demandas, por parte de governos e instituições, ligadas à "gestão pública da pobreza", de novos discursos sobre a favela que subsidiem a política de "integração da favela ao bairro". Em resumo, assistimos hoje à produção intensa de imagens, idéias e práticas que reeditam o antigo mito da favela (VALLADARES, 2000) como um outro mundo social, à parte da cidade, diferente, identificado pela carência e desorganização (VALLADARES, 2006). Dois momentos de tais debates:

As "favelas" - criação genuinamente carioca, não observada em nenhuma outra cidade, mesmo no Brasil - não constituem puramente impiedoso crime contra a estética, elas são particularmente uma grave e permanente ameaça à tranquiilidade e à salubridade pública. Erigidas contra todos os preceitos da higiene: sem água, sem esgotos, sem a mínima parcela de limpeza, sem remoção de lixos; são como largas sentinas cobertas de dejetos e dos demais resíduos da existência humana, amontoados de imundícies e podridões repastando nuvens de moscas, infiltrando nos quarteirões da cidade toda a sorte de moléstia e de impurezas. Desprovidas de qualquer espécie de policiamento, construídas livremente de latas e frangalhos em terrenos do Patrimônio Nacional, libertadas de todos os impostos, alheias a toda ação fiscal: são excelente estímulo à indolência, atraente chamariz de vagabundos, reduto de capoeiras, valhacoitos de larápios que levam a insegurança e a intranqüilidade aos quatro cantos da cidade pela multiplicação dos assaltos e dos furtos. (Trecho do discurso "Para a remodelação do Rio de Janeiro", pronunciado pelo médico Mattos Pimenta, um dos inventores do "problema favela", no Rotary Club, outubro de 1926 apud LAGO e RIBEIRO, 2001:1)

\section{A ofensiva da polícia contra a Canudos do Mal}

A menos de duas semanas dos Jogos Pan-Americanos de 2007, a ofensiva da polícia contra o tráfico encastelado no Complexo do Alemão, na Zona Norte do Rio, nesta quarta-feira, resultou em 19 mortes, sete pessoas vítimas de balas perdidas, um policial baleado assim como cinco traficantes. O comando do 16o Batalhão (Penha) acredita que pode chegar a 30 o número de mortos. Foram muitos tiros, granadas, choro, cadáveres sem direito a vela. A polícia acredita que a maioria dos mortos é ligada ao tráfico de drogas. Ainda não houve queixa de moradores sobre prováveis inocentes mortos. E até agora quando escrevo essa nota não há sinal de conflito no Alemão. Sempre que um inocente tomba, os moradores logo se organizam para tomar o asfalto. Dessa vez não houve nada disso. Só a perda dos parentes dos mortos, que muitas vezes sabem que eles eram do 
"movimento". (Jorge Antônio Barros, repórter policial do Jornal Extra em 28 de junho de 2007)

O pressuposto (LAGO e RIBEIRO, 2001; LAGO, 2003; SILVA, FERNANDES e BRAGA, 2008) é de que há um conflito, exposto publicamente através da mídia, em torno de uma nova representação da favela como o lugar da criminalidade, que se soma hoje à representação até então predominante da favela como lugar da pobreza e da ilegalidade urbana. $\mathrm{O}$ foco da problematização da favela hoje, tanto no campo político quanto acadêmico, é a violência urbana, e a discussão sobre a ilegalidade da moradia é marcada por esse fenômeno. A relação inexorável da ilegalidade com a pobreza, descrita anteriormente, reafirma a atual representação do pobre urbano como criminoso e o enquadramento daquele que pratica sistematicamente atos ilícitos. Veremos que a renovação desse arquétipo se materializa em ordem geral nas favelas, mais explicitamente nos chamados "complexos de favelas" ou em áreas que na vida cotidiana são denominados "faixas de Gaza", isto é, áreas onde há grupos com estratégias territoriais e cotidiano de procedimentos conflitantes, tais como milícias e facções de tráfico de drogas (Amigo dos Amigos, Comando Vermelho e Terceiro Comando Puro) em embate.

Denota-se daqui que a construção de infra-estrutura é permeada por tais fatos. Por exemplo, as obras do Programa Favela Bairro tiveram interferência explícita de tais ações, sendo que a presença do Estado e da mídia ocasionou mudança no traçado e na viabilidade de algumas obras (BARBOSA e SILVA, 2009; FERNANDES, SILVA e BRAGA, 2008) como constatamos em trabalhos de campo.

Nunes (2010), ao analisar os meios de comunicação de massa, principalmente jornais de grande circulação no estado do Rio de Janeiro, sustenta que desde o término do último Programa Favela-Bairro as favelas passaram a ser estereotipadas na imprensa escrita através de conteúdos associados ao descontrole do crescimento, reafirmando uma pauta de "monstruosidade do problema-favela", também ao medo (associação entre índices de criminalidade e violência amplamente difundidos pela grande mídia) e à responsabilização pelas "perdas ambientais" que insistentemente são apresentadas à população em geral. Essas retóricas discursivas retornam a pauta e são apresentadas soluções travestidas no discurso da ordem e da modernidade de gestão tentando ocultar seu conteúdo: mais uma rodada de expulsões de moradores e valorização de áreas nobres da cidade.

Nunes (2010) afirma que constantemente, em inúmeras matérias de jornais, contendo inclusive entrevistas com o prefeito do município, com o governador do estado e com seus secretários de segurança, meio ambiente e "ordem pública", existe a reafirmação de uma 
retórica do "poder destrutivo" que os moradores de favela portam na "destruição do meio ambiente". Esse potencial concretiza-se na responsabilização pela degradação da vegetação, devastação de áreas de proteção ambiental e das condições ambientais que suas moradias em “áreas de risco" causam de transtorno ao Poder Público. Nunes (2010) analisa ainda que há nessa equivocada narrativa uma apresentação dos problemas que demonstra como toda a cidade é responsabilizada pelos problemas das favelas, e transforma os moradores de favela em uma espécie de 'inimigo' de um meio ambiente saudável e de uma qualidade de vida que se pretende preservar.

Os problemas ambientais aparecem como um fenômeno em si e resolvidos em si, e ocultam os fundamentos sociais dessa problemática. Os conflitos de classe e as relações homem-natureza são subsumidas, autonomizando as formas e dando conteúdos ambientais abstratos, turvando os conteúdos sociais concretos da apropriação da sociedade pela natureza

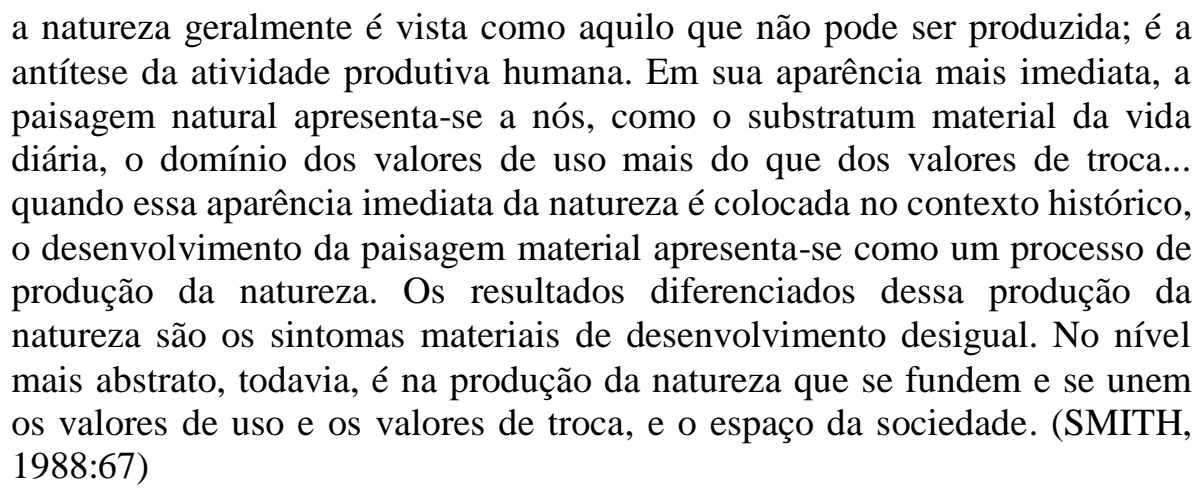

$\mathrm{Na}$ opacidade discursiva realizada pelo aparelho do Estado e difundida pelos meios de comunicação de massa há uma dupla exteriorização. Na primeira, a natureza (e a problemática ambiental) é exteriorizada da sociedade numa ação de "proteção" à natureza, que na verdade é uma regulamentação da propriedade privada da terra e de sua apropriação. Consideramos importante reafirmar que para o capital realizar-se em sua essência, que é a reprodução ampliada, se necessita de uma radical separação entre o trabalhador e a natureza, desfazer violentamente seus vínculos orgânicos com ela e seus recursos, e assim separá-los entre si. Na segunda, a favela é exteriorizada da cidade, não mais considerada como o produto aparente numa sociedade fundada na contradição entre capital e trabalho, mas como a urbanização descontrolada e desordenada. A natureza culpabilizada pelo aparelho de Estado vinculado ao capital financeiro-imobiliário é ora a vitima e ora a vilã, e o favelado tal qual. O econômico que opacifica o social e o político se perde nessa relação ilusória e funcionalista. Os meios de comunicação de massa funcionam como os projetores e muitas vezes criadores das imagens 
que reafirmam o espetáculo, a miséria da vida cotidiana submetida a potência ideológica do capitalismo e as idéias e ideais burgueses.

Tais perspectivas tiveram a intenção de demonstrar as ilusões da transparência e da opacidade na leitura da questão social do abastecimento de água na Zona Oeste da cidade do Rio de Janeiro. Veremos agora como tais perspectivas se substanciam em favelas na periferia do extremo oeste da cidade. 


\section{A urbanização da sociedade e a mundialização do capital: processos e situações para compreender as favelas da periferia da cidade do Rio de Janeiro e o abastecimento de água como raridade}

A urbanização é um processo em constituição, virtualidades e possibilidades, que transcende o simples crescimento populacional ou o crescimento das cidades. Compreendemos que temos como tarefa estudá-lo para além dos fenômenos de aglomeração e crescimento, não negligenciando essas perspectivas. A urbanização relaciona-se com a mundialização do capital e como virtualidade do capitalismo ligada à reprodução da sociedade urbana, que pretende ser homogênea. Oseki (1996) salienta que o dinheiro como uma abstração da equivalência dos bens materiais criados pelo homem passa a dominar os homens que trabalham e produzem, e o capital impõe uma organização e um modo de produzir a toda sociedade. Sendo assim, o urbano constituído como uma abstração concreta, isto é, com uma existência mental e uma prática social, encontra-se cindido entre valor de uso e valor demonstrando uma de suas características: realizar-se como mercadoria. O urbano implode ganhando novos conteúdos, como a cidade objeto de planejamento de estratégias e oportunidades, a competição entre as cidades na atratividade de investimentos financeiros e mega-eventos, a produção de "novas raridades" - como o espaço (além da água, do ar, do solo) -, a transformação do espaço em mercadoria, a espetacularização e visibilidade dos projetos urbanos e a impossibilidade de ativismo social dada a divisão de trabalho e ausência de tempo livre assolada pela precarização do trabalho ${ }^{40}$, como refletem Mattos (2009), Carlos (2003), Lefebvre (2008a; 2008b), Seabra (2003) e Damiani (2009).

Nossa trama de interpretação da problemática urbana é a relação entre a reprodução ampliada e a mundialização do capital na economia essencialmente capitalista. Uma das marcas dessa sociedade é a impossibilidade do urbano para todos, expressão do momento da crise estrutural do capital. Nas análises de Damiani (2009), a existência da urbanização para

\footnotetext{
${ }^{40}$ Marx (1985: 211-212) argumenta que a voracidade do capital por mais trabalho “(...) atropela não apenas os limites máximos morais, mas também os puramente físicos da jornada de trabalho. Usurpa o tempo para o crescimento, o desenvolvimento e a manutenção sadia do corpo. Rouba o tempo necessário para o consumo de ar puro e luz solar. Escamoteia tempo destinado as refeições para incorporá-lo onde possível ao próprio processo de produção, suprindo o trabalhador, enquanto mero meio de produção, de alimentos, como a caldeira, de carvão, e a maquinaria, de graxa ou óleo. Reduz o sono saudável para a concentração, renovação e restauração da força vital a tantas horas de torpor quanto a reanimação de um organismo absolutamente esgotado torna indispensáveis. Em vez da conservação normal da força de trabalho determinar aqui o limite da jornada de trabalho é, ao contrário, o maior dispêndio possível diário da força de trabalho que determina, por mais penoso e doentiamente violento, o limite do tempo de descanso do trabalhador. O capital não se importa com a duração de vida da força de trabalho".
} 
uns exclui a possibilidade para todos, pois na forma de produção do mundo tal qual está posto não é possível a urbanização para a totalidade dos habitantes das metrópoles. Assim, enfrentar e questionar os debates acerca da propriedade privada e da capitalização com a produção do espaço é um desafio. A forma de aparência e gênese dessa estrutura pode ser observada por vários prismas: a problemática da urbanização, dos sem-terra, do meio ambiente, ou seja, nas questões sociais que são impossibilidades desta e nesta sociedade.

Apoiados nas considerações de István Meszáros (2009) e de Andrea Rocha (2010) entendemos que em inúmeros momentos há um equívoco de fragmentar a ideologia da economia para camuflar a realidade concreta, pois a lógica capitalista é extremamente perversa, já que é na abundância que a disparidade aumenta, ou seja, quanto mais há acúmulo de riquezas para alguns (proprietários dos meios de produção), mais cresce a pobreza para outros (trabalhadores). Karl Marx (1988: 251) já observava que os proprietários dos meios de produção acumularam riquezas e os despojados dos meios de produção nada tem para vender senão seu dispêndio de trabalho. Essa relação social originária revela o conteúdo que substancia a pobreza da grande massa que até agora, apesar de todo o seu trabalho, nada possui para vender senão a si mesmo. Nesse processo de subjugações constantes, a violência foi um mote central no processo de expropriações dos meios de produção que permanecem como acumulação originária até hoje.

Desse modo, não há como administrar esses termos das contradições da produção e reprodução e mantê-los, senão em crise. Sob essas espessas camadas, compreendemos a relação entre a problemática urbana na qual está inserida o abastecimento de água como questão.

Tal como Martins (2004) expõe, nós não partimos das favelas como objeto de estudo, nós chegamos a ela por meio do movimento entre teoria e prática da nossa pesquisa, fundamentalmente, pois as favelas da periferia carioca mostraram-se portadoras de situações reveladoras das contradições. Ressalta-se que a escolha do método de análise revela o modo que o pesquisador compreende a realidade e as contradições sociais, pois no método está a visão de homem e mundo que permeia as percepções do pesquisador, suas reflexões e análises. Marx nos faz refletir que o movimento "do abstrato para o concreto não é senão a maneira de proceder do pensamento para se apropriar do concreto, para reproduzí-lo como concreto pensado. Mas este não é de modo nenhum o processo de gênese do próprio concreto" (MARX, 1985). Em nossa pesquisa partimos do materialismo histórico e dialético como método fundamental, por observarmos a relação entre a particularidade e a totalidade 
num movimento de explicações e contradições das relações sociais que analisamos. Assim, Marx (1987) afirma

[...] o concreto é concreto porque é a síntese de muitas determinações, isto é, unidade do diverso. Por isso o concreto aparece no pensamento como o processo da síntese, como resultado, não como ponto de partida, ainda que seja o ponto de partida efetivo e, portanto, o ponto de partida também da intuição e da representação [...]. (MARX, 1987: 16)

Com essas premissas iniciamos o conjunto de trabalhos de campo da pesquisa em tela. Desse modo, nos embrenhamos pelo aparelho de Estado em entrevistas e diálogos tentando compreender o abastecimento de água na periferia do extremo oeste da cidade do Rio de Janeiro, em especial em favelas, espraiadas entre os bairros de Santa Cruz e Paciência durante os meses de junho e julho de 2009. O momento posterior foi o de realizar trabalhos de campo, inicialmente, na favela das Três Pontes (a única presente no programa Favela Bairro 1) e compreender os processos que ocorreram na sua escolha, na realização das obras e no impacto das intervenções realizadas, em julho de 2009, posteriormente em dezembro de 2009 e janeiro de 2010 e finalmente entre novembro e dezembro de 2010.

Ressalva-se que não fomos a campo no intuito de confirmar nossas hipóteses, pois o trabalho de campo se constitui no processo de pesquisa como um todo e não um momento de empirismo dos debates. O processo foi uma tentativa de estabelecer uma relação entre teoria e prática no qual o estudo das particularidades nos remete constantemente ao todo contraditório. Destaca-se ainda que nosso encontro mais profundo e vertical com a obra de Karl Marx foi num momento em que estávamos em um ponto de inflexão da pesquisa. As relações sociais que observávamos precisavam de uma compreensão sobre a totalidade dos processos, e assim nos deparamos com o desafio da práxis marxiana e marxista.

Encontramos nos trabalhos de campo uma realidade complexa, intrincada e desafiadora numa urbanização crítica onde as favelas se estendem continuamente. A favela das Três Pontes, que seria nosso foco na realização dos trabalhos de campo, é um fragmento de um conjunto de 11 favelas de morfologia parecida e produções diferenciadas. As considerações de Spósito (2000) nos auxiliaram a pensar as relações entre forma (morfologia) e conteúdo (processo) do produto e dos produtores do espaço social.

Se tomamos a cidade como forma espacial que expressa a dinâmica e a acumulação de tempos engendradas por esse processo, não podemos deixar de considerá-la como expressão material da urbanização. Por outro lado, o fato de que a urbanização é um processo e a cidade, uma forma espacial não deve nos levar à concepção estática da realidade urbana, a partir da qual a leitura da cidade deve ser feita através de sua morfologia, e a da urbanização através de seu processo. É apenas na relação entre o processo e a forma 
engendrada que podemos compreender como um dado arranjo sócioespacial é, ao mesmo tempo, produto e produtor da realidade (SPÓSITO, 2000: 86).

Para isso nos propomos o desafio de compreender o panorama da produção desse fragmento do espaço, sem negligenciar nosso olhar norteador sobre o abastecimento de água.

Compreendemos em um sentido político, social e econômico que é funcional e estrutural a produção e a manutenção da raridade da água para os moradores das favelas da periferia do Rio de Janeiro. A raridade da água é sinônimo de precariedade, ineficiência e intermitência e não necessariamente a completa ausência do abastecimento. Essa massa de expropriados $^{41}$ (do campo para a cidade e de favelas das áreas centrais da cidade para áreas periféricas) convivem cotidianamente com essa raridade na reprodução de suas vidas. Seus locais de moradia e sociabilidades podem a qualquer momento de expansão econômica de áreas próximas sofrer outra expropriação de seus territórios devido ao processo de valorização do solo urbano do seu entorno seguindo os fluxos e vetores da reprodução da metrópole. As imensas áreas de favela na periferia são observadas como estoques territoriais para possíveis acumulações originárias do espaço.

As políticas de urbanização de favela com sua aparência e discurso de integração entre cidade e favela não fazem mais do que paliativamente dotar fragmentos do espaço de infra estrutura urbana inconclusa. Assim, as redes de infra-estrutura de abastecimento de água seguem uma lógica perversa de distribuição pelos fragmentos de espaço conforme verificamos. Observou-se ainda a manutenção da violência como prática cotidiana das ações e intervenções na produção social do espaço desses moradores.

Neste sentido, desvendar a urbanização trata-se de uma tarefa relacionada a desvendar este urbano que surge a partir da zona crítica evitando o "campo cego para os que se atêm a uma racionalidade já superada" (LEFEBVRE, 2001:87-88).

\subsection{Redes de infra-estrutura de abastecimento de água}

O processo que tentamos desvendar nessa seção é o papel das redes de infra-estrutura urbana de abastecimento de água. Nesse processo, constatamos que as modernas redes de infra-estrutura urbana construídas no Rio de Janeiro (KLEIMAN, 2001; 2009) contribuíram decisivamente na produção social do espaço urbano. As redes de infra-estrutura são capazes

\footnotetext{
${ }^{41}$ Nossa compreensão, tal qual argumenta Chesnais (1999), é a de que o modo de produção capitalista se sustenta e é sustentado por relações sociais constituídas a partir de mecanismos de dominação do capital sobre o trabalho. $\mathrm{O}$ autor enfatiza que o capitalismo é fundado determinantemente pela expropriação do trabalhador e pela apropriação privada da natureza, e este mecanismo torna-se ainda mais intenso sob o processo de controle sociometabólico que caracteriza o capitalismo mundializado.
} 
de veicular, estocar, tratar e de distribuir bens de consumo conectando a produção ao consumo. Porém, não são elementos apenas de distribuição ou suporte físico, mas estruturas de serviço, pois é através das redes que são oferecidos aos habitantes das cidades os serviços como o abastecimento de água ${ }^{42}$.

As redes de infra-estrutura apresentam também uma interdependência entre si, por exemplo, a energia elétrica é essencial para a economia política da distribuição do abastecimento de água. Porém, a água tornada raridade na mundialização do capital é também um fluxo, possibilitado através da rede de distribuição de realizar-se como mercadoria. Outra característica das redes de abastecimento é a relação contraditória entre quantidade e qualidade das infra-estruturas e dos serviços à rede de água potável. Em outras palavras, receber o abastecimento de água não significa que há água de qualidade na torneira.

David Harvey em seu livro "O novo imperialismo" (2005) busca compreender a ordenação espaço-temporal do capitalismo. Para o autor, esse modo de produção é tendencialmente propício a crises de sobreacumulação, assim os processos de produção e reprodução do espaço estão diretamente relacionados às condições impostas pela

\footnotetext{
${ }^{42} \mathrm{O}$ processo de produção de água potável consiste em: captação, adução, tratamento, reservação, distribuição e consumo, podendo-se inclusive refletir sobre a economia política da água (e a necessária Crítica a Economia Política da água) a partir dessa rede técnica, pois se está incorporando trabalho à agua tornando-a mercadoriaágua. Inicialmente, realiza-se a captação do produto, que pode ser a partir de fontes de água superficiais ou subterrâneas. Num segundo momento ocorre o que se chama de adução, que consiste em fazer com que a água coletada chegue até as estações de tratamento de água (ETA). Depois do processo de tratamento a água vai para o reservatório e para a rede de distribuição até os domicílios. Sobre a Economia Política da água é importante observarmos as informações da CEDAE (2010): "A principal estação de tratamento da CEDAE é a ETA do Guandu, abastecida pelas águas do Rio Guandu. A CEDAE capta do Rio Guandu cerca de 42 mil litros de água por segundo e aproveita a ação da gravidade para a captação. As tomadas de água são protegidas para evitar a entrada de materiais mais grosseiros e, dali, a água vai para os desarenadores, para remover areia e outros materiais. Saindo dos desarenadores, a água vai para as estações elevatórias e é bombeada até as estações de tratamento. $\mathrm{O}$ tratamento de água pode ser feito de diferentes maneiras. O processo convencional, realizado pela CEDAE, consiste nas seguintes etapas: Floculação: a água recebe sulfato de alumínio ou cloreto férrico e as impurezas se aglutinam formando flocos em tanques chamados floculadores. Decantação: os flocos de sujeira precipitam-se e depositam-se no fundo do decantador. Filtração: ocorre a retenção dos flocos menores que não ficaram na decantação. Todas as impurezas restantes devem ser removidas nessa etapa. Na CEDAE os filtros utilizados são de areia. Desinfecção: o cloro é usado para destruição de microorganismos presentes na água. Após a adição de cloro, a cal virgem é usada para retirar a acidez da água. Fluoretação: adição de flúor. Depois de tratada, a água é novamente aduzida para os reservatórios da rede e distribuída através de rede de canalização até os domicílios da população abastecida. Os sistemas de abastecimento de água geralmente são formados pelos seguintes componentes: processo de captação, estação de tratamento, redes de distribuição e conexões domiciliares" (CEDAE, 2010).

$\mathrm{O}$ rio Guandu e seus afluentes encontram-se também fortemente poluídos em função de processos de ocupação em suas margens e da inexistência de sistemas adequados de coleta e tratamento de esgotos nos municípios que compõem o território da bacia. O Sistema Guandu existe desde 1955, mas a lei que cria a Área de Proteção Ambiental do Rio Guandu só foi aprovada em 2002. Segundo dados expostos por Britto e Formiga-Johnsson (2010) a "CEDAE gasta em média 318 toneladas de produtos químicos (cerca 250 toneladas de sulfato de alumínio, 18 toneladas de cloro, 30 a 40 toneladas de cal, 10 toneladas de fluor), além de 100 quilos de polímeros por dia, apenas para tratar a água captada pelo Sistema Guandu. Há alguns anos, nota-se certa sobrecarga no sistema, que já levou a suspensão da produção de água potável em algumas ocasiões, em função de problemas de qualidade oriundos de estiagens ou de chuvas fortes".
} 
mundialização do capital: excedentes de trabalho e excedentes de capital. A mercadoriaespaço é uma presa do processo de formação e resolução de crises estruturais. Com esse intento busca a explicação dos circuitos do capital no qual a questão da infra-estrutura é analisada pelo autor como capital fixo incorporado a terra. Vias férreas, rodovias, sistemas portuários, redes de cabos, redes elétricas, sistemas de água e esgoto, etc. são exemplos citados por Harvey (2005). Essas infra-estruturas físicas absorvem um grande contingente de capital, cuja recuperação depende de seu uso in situ. Assim, o capital investido em um sistema de abastecimento de água em que boa parte da população não consiga pagar as taxas é capital perdido. Embora facilite a mobilidade espacial de outras formas de capital e trabalho, o capital fixo investido na terra requer que as interações espaciais sigam o padrão geográfico fixado de seus capitais investidos para que seu próprio valor se realize. Esse olhar é fundamental para compreendermos a questão do abastecimento de água e a crise do abastecimento de água dialeticamente.

Tratando-se das redes de infra-estrutura no Rio de Janeiro, destacamos que em termos político-institucionais, legais e jurídicos distingue-se os chamados recursos hídricos disponíveis ou sistema hidrográfico (no caso da Região Metropolitana do Rio de Janeiro RMRJ - composta de três bacias hidrográficas) e a infra-estrutura de saneamento (dito ambiental). Politicamente, os serviços de saneamento são considerados usuários dos recursos hídricos. Todavia, quando se trata de regiões densamente urbanizadas, essas duas redes passam a ser estreitamente inter-relacionadas a partir da questão da "gestão integrada das águas", que aparece em todas as ações (BRITTO e FORMIGA-JOHNSSON, 2010). Contudo, os diferentes usuários dos recursos hídricos e do saneamento entram em constantes $\operatorname{conflitos}^{43}$, pois a questão da propriedade privada da água não é pauta desses fóruns de debate de "gestão e ordenamento ambiental". Harvey (2005) demonstra que os capitalistas buscam obter vantagens no interior da estrutura espacial em termos de localização buscando custos menores e taxas de lucros maiores. A mediação dos comitês de bacia (que atuam como importantes agentes de gestão das águas) e do próprio Estado não fazem mais do que administrar a profunda crise, pois o fundamento das relações entre esses diferentes sujeitos sociais é a água como mercadoria.

O saneamento, conforme já argumentamos, refere-se aos serviços de abastecimento de água potável; coleta e tratamento de esgotos; drenagem pluvial; e disposição final de resíduos

\footnotetext{
${ }^{43}$ As águas transpostas da bacia hidrográfica do Rio Paraíba do Sul é uma mercadoria disputada entre a geração de energia elétrica no Complexo Hidrelétrico de Lajes, o abastecimento doméstico e os diversos usos industriais da bacia do rio Guandu e da Região Metropolitana do Rio de Janeiro. Essa disputa foi analisada por Paixão (2009).
} 
sólidos. Já a "gestão" de sistemas hidrográficos refere-se às atividades de aproveitamento, conservação, proteção e recuperação da água bruta, em quantidade e qualidade.

Dos 16 municípios que compõem a RMRJ, quase todos têm seus serviços de abastecimento de água e esgotamento sanitário realizados pela companhia estadual, CEDAE (criada em 1975), exceto o município de Niterói, que privatizou a exploração dos serviços em novembro de 1999, conforme expomos no capítulo 1.

Britto e Formiga-Johnsson (2010) argumentam que a política adotada ao longo dos anos privilegiou o abastecimento de água da Região Metropolitana do Rio de Janeiro por intermédio de dois macro-sistemas: o macro sistema-Guandu que abastece o Rio de Janeiro e a maior parte dos municípios a oeste da região hidrográfica da Baia de Guanabara (região da Baixada Fluminense) e o macro-sistema Imunana-Laranjal, alimentado pelas águas dos rios Macacu e Guapiaçu, que abastece os municípios da parte leste dessa região (Niterói, São Gonçalo e Itaboraí).

O rio Guandu constitui o principal manancial de abastecimento para grande parte dos municípios da RMRJ, fornecendo água para cerca de $85 \%$ da população que reside na metrópole. O sistema, gerenciado pela CEDAE, se beneficia de uma transposição de águas da Bacia do rio Paraíba do Sul, cujo rio principal nasce no estado de São Paulo e cruza todo o estado do Rio de Janeiro. As águas assim transpostas para a Bacia do Guandu, inicialmente somente com o objetivo de produção de energia, constituem hoje a principal fonte de água do sistema Guandu (BRITTO E FORMIGA-JOHNSSON, 2010). Embora vários usuários utilizem as águas transpostas, a Região Metropolitana do Rio de Janeiro vive uma situação "relativamente cômoda em termos de disponibilidade hídrica quantitativa até 2025, conforme projeções do Plano de Recursos Hídricos da Bacia do Guandu” (BRITTO e FORMIGAJOHNSSON, 2010). Essa afirmação de Britto e Formiga-Johnsson (2010) demonstra que há um descompasso entre a quantidade e a qualidade da água, por exemplo, a contradição entre a disponibilidade hídrica e a raridade da água nas periferias metropolitanas.

A opção pelos macro-sistemas de abastecimento, que fornecem água para a maior parte da população, foi necessária porque a Região Metropolitana dispõe somente de bacias de pequeno porte e rios de baixa vazão (BRITTO e FORMIGA-JOHNSSON, 2010). As autoras enfatizam, porém, que essa opção fez com que parte dos micro-sistemas baseados na captação de mananciais locais fosse progressivamente abandonada. Hoje, a maior parte desses mananciais é inclusive fortemente poluída, inviabilizando o seu uso para consumo humano.

Todavia, em áreas mais periféricas da metrópole, observam-se situações de grande precariedade em relação ao abastecimento de água. Na sub-região da Baixada Fluminense, as 
situações mais graves são identificadas nos municípios de Queimados, Japeri, Paracambi e Duque de Caxias, que apresentam em torno de $30 \%$ de domicílios sem acesso à rede geral. Em grande parte desta sub-região existem problemas relativos à freqüência irregular do abastecimento, como falta de pressão na rede e má qualidade da água que chega às residências. Dados da Pesquisa Nacional de Saneamento Básico do IBGE de 2000 revelam que existe a necessidade de racionamento de água em praticamente todos os municípios da Baixada Fluminense. As perdas de água na região onde todos os municípios são atendidos pela CEDAE são enormes. Em Japeri, o percentual de perdas na distribuição atinge alarmantes 83,86\% (KLEIMAN, 1996; LAGO, 2009; FORMIGA-JOHNSSON, 2010).

No município do Rio de Janeiro, as situações mais precárias encontram-se nas favelas e nas áreas do extremo oeste, que apesar dos programas de urbanização que vem sendo desenvolvidos, não receberam a mesma prioridade da companhia de água e esgoto. Esta não tem realizado a manutenção dos sistemas implantados pelo Programa Favela-Bairro da Prefeitura, no que tange a melhoria nos problemas de vazamento, ineficiência, racionamento de água e qualidade da água potável.

Nas análises desenvolvidas no presente trabalho, baseadas em autores que já trataram da temática (KLEIMAN, 1996; LAGO, 2009; BRITTO, 2002; MARQUES, 1993) e nos trabalhos de campo realizados nas Secretarias de Urbanismo e na Secretaria de Habitação da Prefeitura da cidade do Rio de Janeiro em junho e julho de 2009, percebe-se que a distribuição de obras de saneamento, apesar de atingir todas as zonas da cidade do Rio de Janeiro, principalmente a partir da década de 1980, apresenta qualidade e quantidade diferenciada, com um maior vulto de investimentos nos fragmentos da cidade onde se encontram nexos entre classes sociais mais abastadas, capital financeiro-imobiliário, áreas valorizadas da cidade e eixos de valorização do espaço urbano, tais como a Zona Sul, Barra da Tijuca e Centro. Mas também para o subúrbio ${ }^{44}$ da cidade, principalmente como afirma

\footnotetext{
${ }^{44}$ Ferreira (2009) tece considerações sobre o subúrbio baseado em Martins (1992) e Fernandes (1995), assim explicitando que: "importa reconhecer, junto com José de Souza Martins (1992, p. 09), que 'a perspectiva elitista do centro domina a concepção que se tem do que foi [e é] o subúrbio'. Tentaremos não nos alongar em demasia, contudo a maneira como essa noção foi e, efetivamente, é utilizada no Rio de Janeiro tem sua especificidade. Fernandes (1995;29) ao investigar a história da categoria subúrbio no Rio de Janeiro entre 1858 e 1945, reconhece que essa palavra sofreu uma transformação em seu significado tradicional, fazendo com que deixasse de representar todas áreas circunvizinhas à cidade para designar, de forma particular e exclusiva, os bairros populares situados ao longo das ferrovias nos setores norte e oeste da cidade do Rio de Janeiro. O autor interpreta a produção do conceito carioca de subúrbio, como o resultado de um rapto ideológico - mudança brusca e drástica do significado de uma categoria, em que seus atributos mais originais e essenciais são expurgados de seu conteúdo, sendo submetidos por significados novos e complemente estranhos à sua extração mais genuína. Esse tipo de reforma implicou na destruição dos bairros proletários centrais e o deslocamento de seus moradores para o subúrbio, que para a ideologia dominante, deveria ser o lócus do proletariado. Em se tratando do Rio de Janeiro, a ausência de uma efetiva política de habitação popular, tornou a casa própria no
} 
Kleiman (2002) para as áreas nobres e/ou centrais de tal espaço (áreas como o Méier, centro de Madureira, centro de Campo Grande e Bangu) beneficiadas pela presença prévia de outras redes existentes (rede viária, ferroviária, elétrica). Em menor proporção a periferia do extremo oeste, favelas e Jacarepaguá, conforme expõe Kleiman (1996).

Pode-se constatar também que o proletariado urbano da Zona Oeste pode se beneficiar indiretamente e precariamente das redes de abastecimento de água construídas, pois dada a sua fonte de produção no sistema Guandu (situado em Nova Iguaçu na Baixada Fluminense, área conurbada à Zona Oeste do município do Rio de Janeiro) a rede teve que passar pela Zona Oeste, o que propiciou o abastecimento através de "sobras" ou "empréstimos" da rede, tendo como conseqüência pequeno volume do líquido e descontinuidade do serviço (ineficiência do sistema).

Por fim, os dados expostos por Faria (2009), ao tabular e analisar as informações censitárias de 2000, nos parecem peremptórios quanto à precariedade dos fragmentos do espaço que realizamos os trabalhos de campo (ou nos marcos do planejamento técnico do Estado AP - 5 Paciência, Santa Cruz, e adjacências). Os dados revelam uma concentração elevada de domicílios com mais de quatro pessoas por dormitório nos bairros da AP-5 e quanto aos precaríssimos percentuais de domicílios atendidos por rede geral de água e esgoto e coleta regular de lixo. Articulando os dados acerca do saneamento, chega-se a patamares de apenas $9,17 \%$ do total de domicílios atendidos por estes serviços simultaneamente.

\subsection{Políticas públicas e o Programa Favela-Bairro}

Há um escopo teórico com mat(r)izes bastante diferenciadas sobre a análise de políticas públicas desenvolvida no âmbito da Ciência Política. Por exemplo, segundo Marques (1998) as quatro correntes centrais da análise das políticas públicas são: pluralismo, teoria das elites, marxismo e neoinstitucionalismo. Essa análise esquemática, em nosso entendimento, apresenta alguns limites, pois insere em um mesmo bloco de análise as diferentes correntes de pensamento dentro do marxismo. Contudo, tomemos a título de didatismo esse esquema.

subúrbio uma miragem para a maioria do proletariado. A partir de então, Fernandes (1995;30) supõe que 'o sentido do 'conceito carioca de subúrbio' experimentou o sentimento e a necessidade ideológica das elites no intuito de afastar as classes subalternas do Rio de Janeiro'. Considerando a advertência de Henri Lefebvre (1976;46) de que o espaço é sempre uma representação carregada de ideologia, o trinômio trem-subúrbiopobreza só veio de fato a se concretizar depois do início do século XX, com o desenvolvimento da ideologia da casa própria no subúrbio. 'Subúrbio', então, passou a ser entendido como as áreas servidas por ferrovia que foram abertas ao proletariado como um dos símbolos das alterações das relações sociais que conformam e caracterizam as reformas urbanas verificadas no Rio de Janeiro" (FERREIRA, 2009: 748-49). 
Sob a perspectiva principalmente da corrente neoinstitucionalista de análise da Política, as ações coletivas de políticas públicas urbanas nas sociedades modernas se constituiriam como alternativas às soluções individuais e/ou voluntárias, sendo o Estado o principal gestor destas ações, como disserta Castro (2002). A análise do Estado institucionalmente, portanto, é tarefa essencial nas análises que problematizem as ações estatais. Para autores referenciados numa leitura da teoria das elites nos marcos de uma urbanização periférica, como proposto por Piquet (1991:49), "investimentos em infraestrutura urbana voltados para os meios de consumo coletivo - habitação, água, esgotos, transportes - não são realizados, pois iriam concorrer com os gastos públicos ligados aos interesses do capital industrial”. A autora considera que na organização do espaço o Estado joga seu papel pela intervenção racional através de planos urbanísticos e de equipamentos e serviços coletivos, no sentido de satisfazer às necessidades do processo produtivo capitalista. Tal racionalidade, conforme expõe Bahia (2000), visa garantir a sucessão das elites no poder.

Para outros autores, principalmente fundamentados no marxismo mais heterodoxo com ênfase em Escobar (1998), Botelho e Barreira (2008) e Porto-Gonçalves (2006), as políticas públicas urbanas aparecem como uma modalidade de controle e de exercício do poder que pode ser encontrado nos discursos sobre desenvolvimento, ordenamento do espaço e gestão de populações. Para estabelecer os parâmetros desejados de desenvolvimento, ou seja, aferir ordem à desordem, legalidade à ilegalidade, é preciso identificar e ordenar a produção social do espaço. A tendência de ordenamento do espaço e atribuição de características morfológicas específicas a cada um deles é o que unifica e normatiza os diferentes discursos sobre desenvolvimento e as práticas administrativas.

De uma perspectiva do marxismo ortodoxo, Oliveira (2003) desconstrói a ideia de Estado de todos, fundamentando a análise do Estado de Exceção. O autor analisa que o Estado funciona como condição da normatização do espaço urbano com a finalidade de estabelecer o controle dos conflitos de classe e coercitivamente planejar com o seu aparato o aprofundamento do capitalismo, tanto nos processos de industrialização quanto de urbanização. Assim, o mercado de trabalho foi virado pelo avesso e a "informalidade" tornouse regra, ocorreu a financeirização da economia e dos orçamentos públicos produzindo uma autonomização do mercado e o Estado se funcionalizou como uma máquina de arrecadação para tornar o excedente disponível para o capital. Para Oliveira (2003) então vivemos um Estado de exceção no qual as cidades são o lugar por excelência da exceção, e o conjunto delas é a administração da exceção. 
Para Boito Jr. (2006) baseado nas considerações de Nicos Poulantzas há uma unidade contraditória da burguesia organizada como classe dominante a fim de resguardar e salvaguardar as condições gerais de reprodução do capitalismo a partir do aparelho de Estado das frações de classe burguesa.

Lefebvre (2008:143) é um autor que revela peremptoriamente as ações e intervenções dos tecnocratas e o caráter da produção do espaço para o capitalismo sua reprodução e tentativa de postergação de suas crises. Lefebvre já afirmava que "esse espaço instrumental, o da representação, o dos tecnocratas, não é o espaço social efetuado. Enquanto instrumental, ele tende a se comprimir, a se fechar, a não admitir senão o repetitivo, o significante reconhecido. Entretanto, enquanto espaço de uma prática social, produzido como tal, ele possui características específicas e determinadas". A ilusão da opacidade e a ilusão da transparência da produção social do espaço, principalmente das periferias, são os marcos centrais dos da análise envolvidos e da interpretação em tela.

O estabelecimento de políticas públicas no Brasil é de competência do poder executivo em todas as instâncias governamentais. Elas são criadas por meio de instrumentos legais que definem um determinado aspecto social, cultural, econômico ou de ordenamento territorial como prioritário para atuação do Poder Público, estabelecendo diretrizes, planos, normatizações e metas a serem atingidas (CARDOSO e RIBEIRO, 2003; RANDOLPH, 2004).

Os ministérios, no âmbito federal, e as secretarias estaduais e municipais são responsáveis pelo detalhamento, pelo aprofundamento e pela aplicação das políticas públicas a partir de instrumentos criados especialmente para tais atuações (leis, decretos e normas, programas de trabalho, monitoramento, fiscalização, etc.). Nas cidades, o poder local conta com os Planos Diretores para definir as políticas públicas urbanas.

A Constituição de 1988 estabelece a obrigatoriedade de planos urbanísticos para as cidades com mais de 20 mil habitantes (RESENDE, 2002: 273) e posteriormente estendida a todas as cidades. Em 1992 se cria o Plano Diretor Decenal na cidade do Rio de Janeiro, um amplo projeto de "reforma urbana" elaborado para a "reestruturação do espaço urbano carioca", e a partir desse, o programa Favela Bairro, específico para as favelas (1993-1994).

O objetivo do Programa Favela Bairro foi "integrar a favela à cidade", dotando-a de infra-estrutura urbana, serviços, equipamentos públicos e políticas sociais. Os componentes urbanísticos do programa abrangem abertura e pavimentação de ruas; implantação de redes de água, esgoto e drenagem; construção de creches, praças, áreas de esporte e lazer; canalização de rios; reassentamento de famílias que se encontram em áreas de risco; contenção e 
reflorestamento de encostas; construções de marcos limítrofes para evitar a expansão das favelas; reconhecimento de nomes de ruas e logradouros (MAIA, 2003; PREFEITURA DA CIDADE DO RIO DE JANEIRO, 2005). No que se refere às implementações das políticas de abastecimento no âmbito do Favela Bairro, percebemos que seus pressupostos norteadores são: atingir condições ambientais satisfatórias, acessibilidade de infra-estrutura e equipamentos coletivos à população favelada e, fundamentalmente, as condições de normatização da vida pública e privada que se refere as regulações urbanísticas e o reconhecimento dos direitos de propriedade e de trabalho (PREFEITURA DA CIDADE DO RIO DE JANEIRO, 2008; RIBEIRO, LAGO E DAVIDOVICH, 1997) numa lógica de cidadania adquirida pelo mercado.

Sendo assim, a questão do Programa Favela Bairro se apresenta em destaque, pois se estrutura no discurso da integração da "cidade ilegal à cidade legal" e da competência técnica na realização de suas obras em (suposta) oposição ao clientelismo na realização de obras de urbanização de favelas em políticas pregressas. Em seu nascedouro, o Programa Favela Bairro tinha como perspectiva ser um programa habitacional, para "complementar (ou construir) a estrutura urbana principal (saneamento e democratização dos acessos); oferecer condições ambientais de leitura da favela como um bairro da cidade" (DIÁRIO OFICIAL 20/06/1994). Em relação a seleção das favelas que poderiam ser urbanizadas, o critério "déficit de infraestrutura existente apresenta o indicador único, percentagem de domicílios com serviços inadequados de água potável e esgotamento sanitário" (RANDOLPH, 1997). O que consideramos momentos de relação do abastecimento de água com a produção e reprodução das relações sociais, principalmente sua centralidade para a ação do Estado e das empresas privadas. Além da naturalização do homem em voga com a telescopagem do discurso ambiental.

Pelas definições presentes nos relatórios, projetos e editais analisados, o diagnóstico da "desordem" urbana contida no Programa Favela Bairro é posto para justificar a realpolitik de intervenção urbana, sob a qual se institui um ordenamento do espaço que cria uma imagem de cidade competitiva e que possa se adequar às demandas da mundialização do capital em sua infra-estrutura urbana.

Em sua primeira fase, o Favela-Bairro foi implantado no período do $2^{\circ}$ semestre de 1994 a setembro de 1996 em 15 favelas consideradas consolidadas, de médio porte (500 a 2.500 domicílios) com população entre 2 mil a 10 mil moradores, com investimento de $\mathrm{R} \$ 43$ 
milhões e pretendendo beneficiar cerca de 50 mil pessoas ${ }^{45}$. As razões de escolhas dessas favelas se estruturam nas seguintes premissas: os custos altos para urbanizar favelas de grande porte nesse período de captação de recursos e a dispersão territorial de favelas de pequeno porte. Elaborou-se um índice a partir do qual foram definidos índices de facilidade ou dificuldade de urbanização. Foram selecionadas inicialmente 40 favelas e posteriormente centrou-se o projeto em 15 comunidades.

Segundo entrevista realizada com uma arquiteta da Secretaria Municipal de Habitação $(\mathrm{SMH})$, as favelas já estavam pré-definidas mesmo antes da instituição de tais critérios. Muitas delas já haviam sofrido algum tipo de intervenção pelo Projeto Mutirão ${ }^{46}$ (o "pai do Favela Bairro", segundo a entrevistada). Para Burgos (2006:49) o critério político da escolha foi o interesse de finalização dos programas dentro do calendário eleitoral. Segundo Ruth (moradora entrevistada na Favela das Três Pontes), a realização de obras do Favela Bairro na favela das Três Pontes seguiu fortemente articulada a idéia de "mutirões", o que para ela servia de justificativa por aqueles que realizavam as obras para mantê-las inconclusas, responsabilizando os moradores pela não-finalização das obras que cabiam "ao espaço privado".

A favela, na visão dos entrevistados do aparelho de Estado da Prefeitura, um geógrafo e uma arquiteta da Coordenadoria de Planejamento da SMU, e duas arquitetas da SMH (estas inclusive eram do aparelho burocrático do Programa Favela Bairro 1), consiste numa fração

\footnotetext{
${ }^{45}$ Em dezembro de 1995 o Programa Favela Bairro ganha uma nova amplitude com a assinatura de contrato junto ao BID para a execução do que passou a se chamar Programa de Urbanização de Assentamentos Populares (PROAP). Com esse convênio são delineados "os padrões e parâmetros que permitissem a escolha das áreas beneficiadas, a começar pelo grau de carência da comunidade e também um rígido controle de custos para manter o Programa dentro do orçamento" (PREFEITURA DA CIDADE DO RIO DE JANEIRO, 2003: 19 apud PEREIRA, 2008: 38). Ressalta-se que após a assinatura do contrato os gastos da Prefeitura foram incorporados dentro do valor do convênio. Essa assertiva explicita que apesar do convênio ter sido assinado depois de iniciadas as intervenções em favelas ressalta-se que representantes do BID já acompanhavam o desenrolar do Programa. Uma arquiteta da SMH ressaltou que a escolha por essa agência multilateral foi eminentemente estratégica, pois o foco do Favela Bairro desde o seu nascedouro era urbanizar favelas, e essa era a política do BID. Para a entrevistada "se o foco fosse regularização fundiária o convênio seria com o Banco Mundial que tem know-how nessa prática, mas as ações se concentrariam em urbanização, então escolheu-se o BID”.

${ }^{46}$ Conforme já apontamos, a seleção de favelas para o Programa Favela Bairro teve como germe o Projeto Urbanização Comunitária/ Mutirão. Este era um componente do trabalho social desenvolvido pela Secretaria Municipal de Desenvolvimento Social (SMDS), através da Superintendência de Desenvolvimento Comunitário (SDC). O projeto tinha como objetivo principal o estabelecimento de um trabalho social, a médio prazo em favelas (principalmente), loteamentos e periferias buscando o desenvolvimento de projetos alternativos em áreas de moradia da população pauperizada do Rio de Janeiro. No projeto a SMDS fornecia material para obras de saneamento à população favelada, dando os recursos necessários, tanto materiais como humanos (assistência técnico-social ) e visava elevar o nível de mobilização comunitária e garantir a qualidade dos serviços. O projeto realizava-se em mutirões remunerados e a Favela das Três Pontes teve sucesso na realização dessa empreitada. Bueno (2000) argumenta que esse projeto foi uma experiência precursora em favelas, pois essa política incluía diagnósticos e obras de contenção de risco geotécnico, urbanização integrada de redes de infra-estrutura e projetos de regularização fundiária. O quadro político era propício, com Leonel Brizola no Governo Estadual, reforçando as discussões sobre regularização fundiária, e as ações da LIGHT e CEDAE.
} 
da cidade dotada de características próprias, tanto morfológicas como socioeconômicas. As diferenças residem em que "suas características morfológicas e socioeconômicas apresentam particularidades frente aos bairros". A peculiaridade apresentada pelos entrevistados é a separação da cidade em incluídos e excluídos e as soluções possíveis para esses sujeitos centram-se (fundamentalmente e por que não dizer que muitas vezes exclusivamente) nas intervenções urbanísticas, e isso foi constatado nas entrevistas: a priorização no projeto na transformação da imagem da "comunidade"

O Secretário Extraordinário da Habitação (transformada em Secretaria Municipal de Habitação em 1994) em 1993 já afirmava que

A urbanização vai mais além: busca reduzir e, no limite, extinguir os guetos em que se constituíram grande parte dos aglomerados populares trazendo-os para a integração à cidade, com infra-estrutura sanitária, com democratização aos acessos à regularização fundiária (OFÍCIO DO SECRETÁRIO DO IAB, encaminhando o edital do Concurso FavelaBairro).

Transformar as favelas em bairros parte do pressuposto de que há a possibilidade do urbano para todos, faltando apenas dotar as favelas de "condições urbanísticas". Para tanto, cabe à política habitacional "desestimular a expansão da mancha urbana para o uso residencial em áreas que exigem novas infra-estruturas”. As favelas da periferia portam essas múltiplas determinações e contradições, e devemos portanto nos aproximar ainda mais dessa realidade.

\footnotetext{
${ }^{47}$ Dentre o conjunto de ações para estabelecer a passagem da cidade informal/ilegal à cidade formal/legal e a leitura da favela como um bairro da cidade, se associa um processo generalizado de conceber um novo status às áreas de favelas e suas populações. Reconhecidas a existência das "favelas" como parte integrante da cidade o termo carrega consigo um conjunto de imagens e representações. Ocorre um movimento, então, que propunha um novo olhar sobre o espaço urbano assim como de suas demarcações geográficas, morais e sociais (CASTRO, 2004). Repensar as próprias categorias construídas de identificação e classificação dos agrupamentos sociais. Foi necessário, portanto, fornecer novos conteúdos às práticas políticas e administrativas. $\mathrm{E}$, como corolário deste repensar, o termo "comunidade" aparece como uma expressão capaz de atribuir positividade a estes "aglomerados humanos", conforme terminologia recorrente, (CASTRO, 2004:194), pois o termo é resgatado das experiências ligadas aos chamados "trabalhos comunitários". Sua valoração é explicada por Fernandes (1994:33): "Trabalho comunitário, é uma expressão das mais correntes entre aqueles que circulam pelo terceiro setor. Denota a concretude de uma atividade localizada, de dimensões razoavelmente pequenas, em que o relacionamento é personalizado. Ser local, pequena e personalizada são características que, nesses meios, emprestam valor á comunidade." Desta maneira, como disserta Castro (2004:194-195) "o termo 'comunidade' foi adquirindo pouco a pouco uma aura não apenas de categoria analítica para descrever e analisar determinados aspectos da realidade social, mas passou a indicar padrões de comportamento, e estilos de vida. A valorização da proximidade, de relacionamentos personalizados e familiares são vistos como padrões de comportamento e formas de interação social ditas 'comunitárias', em oposição às relações impessoais, distantes, anônimas, características dos centros urbanos. Passa-se a considerar agora como positivos os comportamentos, costumes, valores, hábitos, estilos de vida, que no passado serviam para desqualificar certos locais de moradia, assim como seus moradores".
} 


\begin{tabular}{|c|c|c|c|c|c|c|c|c|c|c|}
\hline \multirow[b]{2}{*}{ Favelas } & \multicolumn{3}{|c|}{2000} & \multicolumn{3}{|c|}{1991} & \multicolumn{4}{|c|}{ Diferença 2000/1991 em pontos percentuais } \\
\hline & 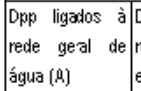 & $\begin{array}{l}\text { Dpp ligados à } \\
\text { rede geral de } \\
\text { esgoto (B) }\end{array}$ & $\left|\begin{array}{lr}\text { Dpp } & \text { com } \\
\text { serviço } & \text { de } \\
\text { coleta de lixo }\end{array}\right|$ & $\begin{array}{l}\text { Dpp ligados à } \\
\text { rede geral de } \\
\text { água (D) }\end{array}$ & 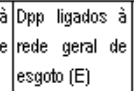 & $\begin{array}{l}\text { Dpp com serviço } \\
\text { de colet de lixo } \\
\text { (F) }\end{array}$ & $\begin{array}{l}\text { Dpp ligados à rede } \\
\text { geral de ácua (A-D) }\end{array}$ & $\begin{array}{l}\text { Dpp ligados à rede } \\
\text { geral de esgoto (B-E) }\end{array}$ & $\begin{array}{l}\text { Dpp com } \\
\text { de coleta } \\
\text { (C-F) }\end{array}$ & $\begin{array}{l}\text { serviço } \\
\text { de lixo }\end{array}$ \\
\hline Total das 34 favelas & $94,67 \%$ & 34,04\% & $96,24 \%$ & $31,24 \%$ & $64,05 \%$ & $79,60 \%$ & 13,63 & 19,99 & & 18,64 \\
\hline Baimo Nova alliança & $99,55 \%$ & $58,43 \%$ & $99,85 \%$ & $100,00 \%$ & $10,10 \%$ & $98,95 \%$ & $-0,45$ & 48,33 & & 0,89 \\
\hline Baimo Projetado do Dique & $93,35 \%$ & $65,46 \%$ & $92,95 \%$ & $86,71 \%$ & $21,44 \%$ & $64,84 \%$ & 6,64 & 44,02 & & 28,11 \\
\hline Buriti Congonhas & $97,84 \%$ & $92,94 \%$ & $99,80 \%$ & $90,39 \%$ & $77,51 \%$ & $61,76 \%$ & 7,45 & 15,44 & & 38,05 \\
\hline Caminho do Job & $98,79 \%$ & $89,29 \%$ & $97,41 \%$ & $96,18 \%$ & $68,26 \%$ & $88,53 \%$ & 2,62 & 21,03 & & 8,88 \\
\hline Conjunto Residencial Femẫo Cardin & $97,38 \%$ & $99,00 \%$ & $100,00 \%$ & $100,00 \%$ & $3,23 \%$ & $99,71 \%$ & $-2,62$ & 95,78 & & 0,29 \\
\hline Divinéia & $99,71 \%$ & $52,63 \%$ & $99,94 \%$ & $98,61 \%$ & $0,81 \%$ & $67,94 \%$ & 1,10 & 51,82 & & 32,00 \\
\hline Faz Quem Quer & $92,60 \%$ & $95,07 \%$ & $99,62 \%$ & $62,13 \%$ & $2,13 \%$ & $66,60 \%$ & 30,47 & 92,94 & & 33,02 \\
\hline Floresta da Bama da Tijuca & $89,40 \%$ & $93,16 \%$ & $99,23 \%$ & $83,79 \%$ & $69,34 \%$ & $92,97 \%$ & 5,61 & 23,82 & & 6,26 \\
\hline Jamelẵo & $70,35 \%$ & $98,55 \%$ & $100,00 \%$ & $15,57 \%$ & $35,93 \%$ & $45,51 \%$ & 54,78 & 62,62 & & 54,49 \\
\hline Mato Alto & $99,06 \%$ & $95,88 \%$ & $99,88 \%$ & $98,83 \%$ & $34,81 \%$ & $98,57 \%$ & 0,23 & 61,08 & & 1,31 \\
\hline Moisés Sartana & $96,36 \%$ & $100,00 \%$ & $100,00 \%$ & $100,00 \%$ & $0,96 \%$ & $24,04 \%$ & $-3,64$ & 99,04 & & 75,96 \\
\hline Moro da Casa Branca & $99,34 \%$ & $98,52 \%$ & $100,00 \%$ & $99,84 \%$ & $94,50 \%$ & $99,68 \%$ & $-0,50$ & 4,02 & & 0,32 \\
\hline Morro da Fé & $98,42 \%$ & $97,28 \%$ & $99,86 \%$ & $100,00 \%$ & $94,49 \%$ & $90,30 \%$ & $-1,58$ & 2,79 & & 9,55 \\
\hline Morro da Formiga & $77,53 \%$ & $58,69 \%$ & $98,88 \%$ & $17,57 \%$ & $16,10 \%$ & $23,01 \%$ & 59,95 & 42,59 & & 75,86 \\
\hline Morro do Fubá & $91,66 \%$ & $94,18 \%$ & $86,85 \%$ & $55,73 \%$ & $29,16 \%$ & $54,05 \%$ & 35,93 & 65,02 & & 32,81 \\
\hline Moro do lguaika & $98,94 \%$ & $87,77 \%$ & $73,40 \%$ & $21,52 \%$ & $19,30 \%$ & $15,82 \%$ & 77,42 & 68,46 & & 57,58 \\
\hline Morro do Sapê & $35,22 \%$ & $93,40 \%$ & $97,80 \%$ & $97,23 \%$ & $29,41 \%$ & $21,45 \%$ & $-62,01$ & 63,98 & & 76,35 \\
\hline Morro do Sossego & $99,43 \%$ & $99,43 \%$ & $100,00 \%$ & $63,43 \%$ & $53,53 \%$ & $98,94 \%$ & 36,01 & 45,90 & & 1,06 \\
\hline Morro do Unubu & $99,35 \%$ & $95,61 \%$ & $98,23 \%$ & $90,00 \%$ & $59,49 \%$ & $67,35 \%$ & 9,26 & 36,12 & & 30,87 \\
\hline Morro Mata Machado & $91,43 \%$ & $98,61 \%$ & $100,00 \%$ & $18,40 \%$ & $53,23 \%$ & $90,41 \%$ & 73,04 & 45,38 & & 9,59 \\
\hline Morro Uniä̃o & $99,06 \%$ & $98,59 \%$ & $100,00 \%$ & $38,35 \%$ & $89,25 \%$ & $99,64 \%$ & 60,71 & 9,34 & & 0,36 \\
\hline Parque Boa Esperança & $100,00 \%$ & $97,91 \%$ & $91,65 \%$ & $87,30 \%$ & $1,06 \%$ & $35,45 \%$ & 12,70 & 96,85 & & 56,20 \\
\hline Parque Proletário do Grotấo & $95,03 \%$ & $97,69 \%$ & $99,54 \%$ & $95,19 \%$ & $88,40 \%$ & $96,06 \%$ & $-0,15$ & 9,29 & & 3,48 \\
\hline Parque Royal & $97,47 \%$ & $92,04 \%$ & $100,00 \%$ & $58,76 \%$ & $32,90 \%$ & $98,56 \%$ & 38,71 & 59,13 & & 1,44 \\
\hline Parque vitóíria & $99,37 \%$ & $95,62 \%$ & $100,00 \%$ & $98,00 \%$ & $97,50 \%$ & $99,04 \%$ & 1,29 & $-1,89$ & & 0,96 \\
\hline Pq.Sẫo Sebastẫo e Lad.dos Funcionários & $98,53 \%$ & $93,03 \%$ & $100,00 \%$ & $82,97 \%$ & $96,83 \%$ & $100,00 \%$ & 15,56 & $-3,80$ & & 0,00 \\
\hline Quinta do Caju & $97,97 \%$ & $56,63 \%$ & $100,00 \%$ & $99,85 \%$ & $92,06 \%$ & $100,00 \%$ & $-1,88$ & $-35,43$ & & 0,00 \\
\hline Serinha & $98,45 \%$ & $91,18 \%$ & $96,90 \%$ & $68,33 \%$ & $50,56 \%$ & $70,28 \%$ & 30,12 & 40,62 & & 26,63 \\
\hline Três Portes & $99,53 \%$ & $37,06 \%$ & $98,70 \%$ & $99,42 \%$ & $2,19 \%$ & $98,61 \%$ & 0,11 & 34,86 & & 0,08 \\
\hline Tuiuti & $99,65 \%$ & $98,94 \%$ & $100,00 \%$ & $94,50 \%$ & $7,72 \%$ & $73,65 \%$ & 5,15 & 91,22 & & 26,35 \\
\hline Vidigal & $98,30 \%$ & $96,92 \%$ & $100,00 \%$ & $94,45 \%$ & $76,34 \%$ & $94,32 \%$ & 3,85 & 20,57 & & 5,68 \\
\hline Villa Sapê & $99,43 \%$ & $97,85 \%$ & $100,00 \%$ & $98,47 \%$ & $22,81 \%$ & $98,19 \%$ & 0,96 & 75,04 & & 1,81 \\
\hline
\end{tabular}

Fonte: IBGE. Censos Demográficos 1991 e 2000.

Cálculos e tabulaçẫo: IPPIDIG/GSD

Nota: $d p p$ = domicilios particulares permanentes

Fonte: Prefeitura da cidade do Rio de Janeiro, 2005.

Tabela 3: Implementação dos serviços de infra-estrutura em favelas urbanizadas pelo Programa Favela-Bairro ( $1^{\text {a }}$ etapa) em 2000. 


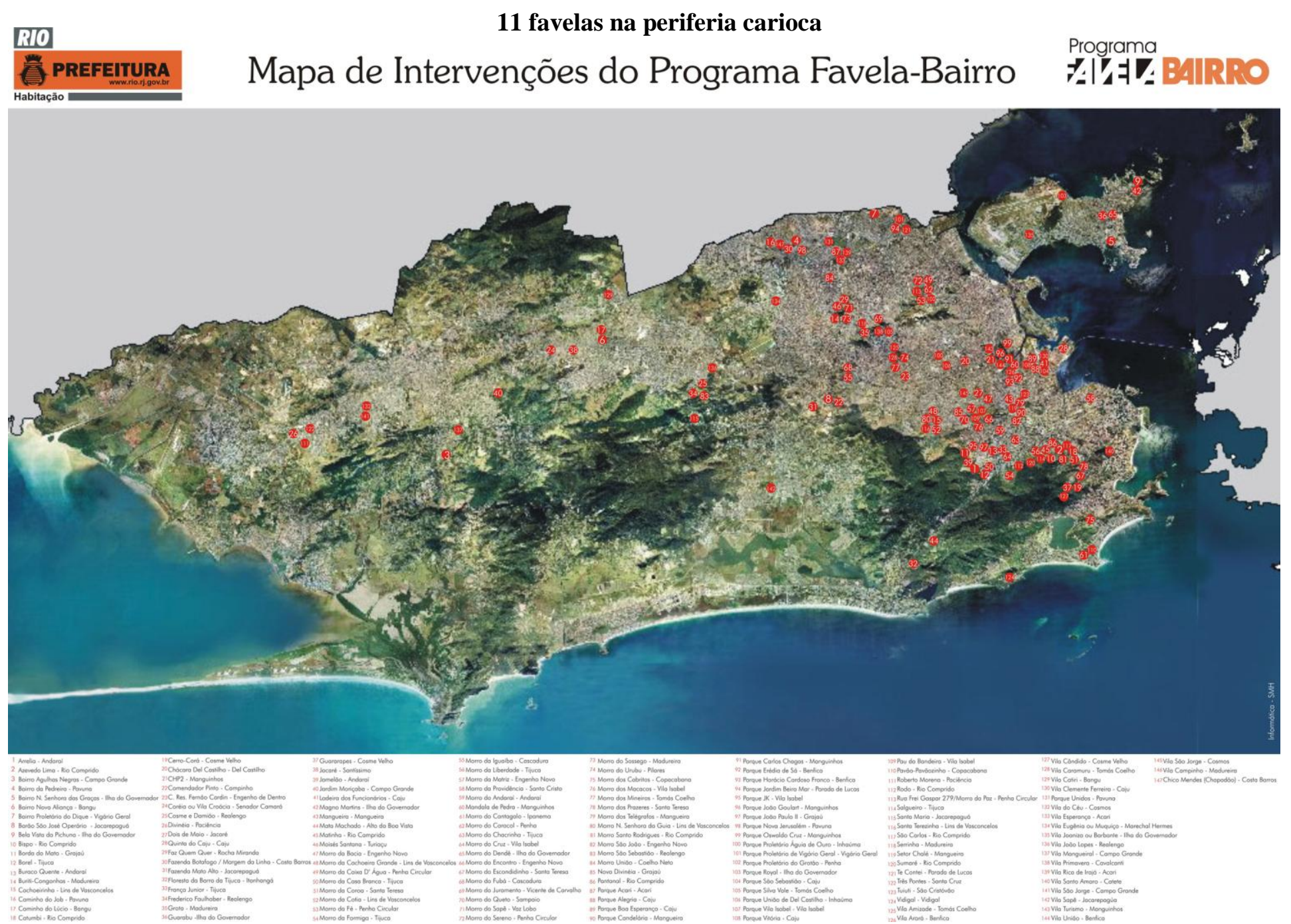

Fonte: Secretaria Municipal de Habitação da cidade do Rio de Janeiro. Disponível em www.rio.rj.gov.br/habitacao. Acesso em 21 de fevereiro de 2009. Mapa 5: Mapa de Intervenções do Programa Favela-Bairro em 2008. 
120

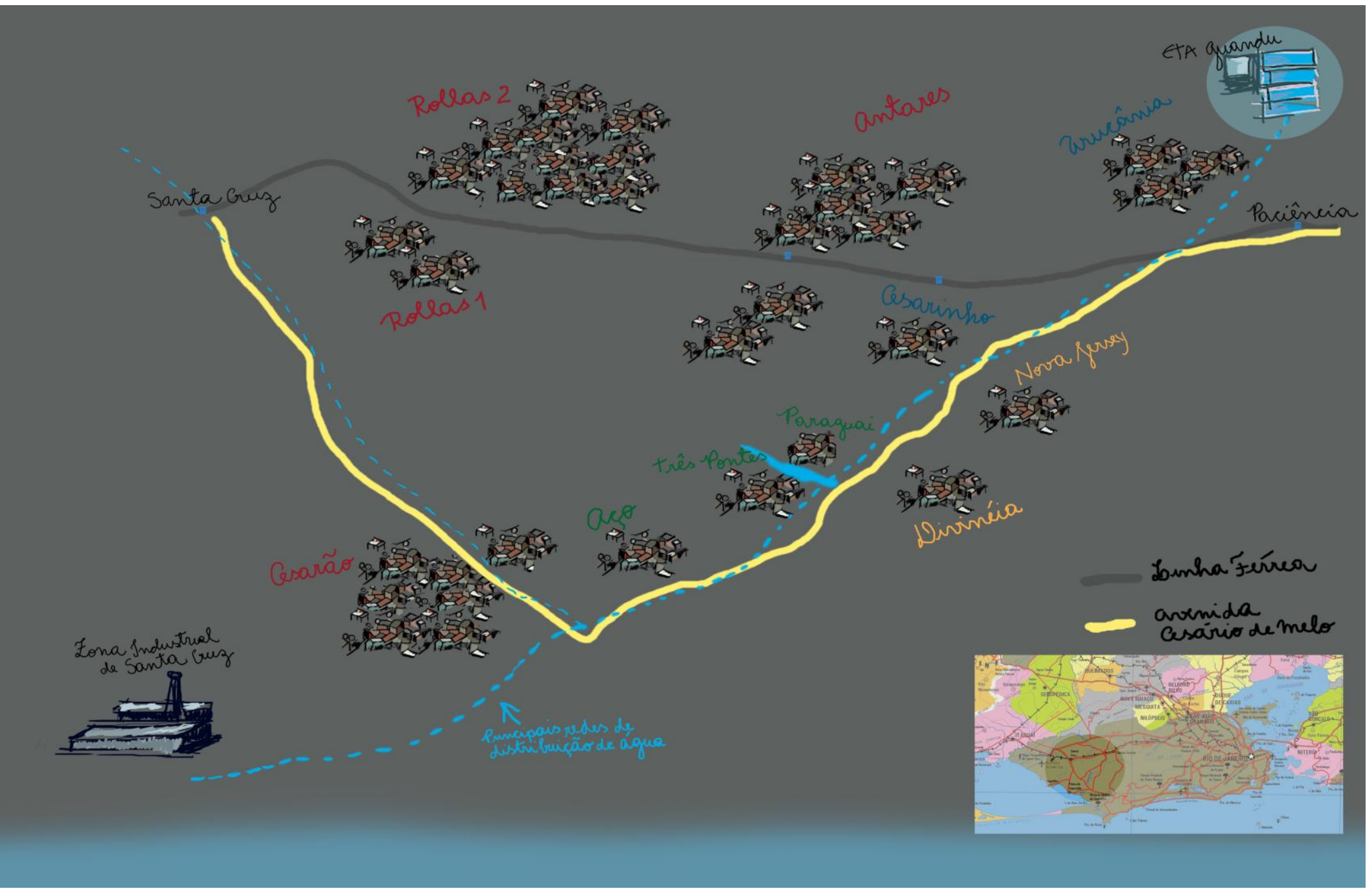

Imagem 7: Croqui da área de realização dos trabalhos de campo na Zona Oeste do Rio de Janeiro 


\subsection{A urbanização (crítica) da sociedade: trabalhos de campo em favelas da periferia carioca}

\subsubsection{Três Pontes: uma favela na periferia carioca (única da Zona Oeste entre os primeiros selecionados no Programa Favela Bairro 1)}

Fui à favela das Três Pontes pela primeira vez levado pela professora e amiga Cristiane Mattos em junho de 2009. Foram cinco visitas em dias e horários diferentes. Dentre as visitas realizei um percurso de bicicleta que me levou ao reconhecimento daquela favela e da verificação de muitas outras. O caderno de campo daquele dia demonstrava minhas impressões e inquietações: "como realizarei essa pesquisa? As favelas não tem fim. Entre Paciência e Santa Cruz consigo observar produções diferentes, mas como farei para conhecer essas realidades para além da paisagem? A Favela das Três Pontes apresenta plaquinhas com seu nome estampado querendo ordenar, querendo demonstrar, querendo integrar favela ao bairro, mas que bairro? Que urbanização é essa?”. Nesse momento estava inquieto com uma "certa" continuidade morfológica da produção desse fragmento do espaço. Instigava-me, porém, a dimensão da vida cotidiana, e quando sistematizei as impressões desse trabalho de campo redigi em meu caderno: "estou diante de um contínuo de precariedade, a reprodução da sociedade urbana e a crise estão diante de mim, é assim que percebo essa produção agora. Porém, como analisarei esse fato articulado com a reprodução da vida".

Nas conversas de reconhecimento, num dos bares que paramos para bebericar e conversar, um dos senhores que nos atendeu relatou as diferentes formas de como se deu a passagem contraditória de uma área de sítios e fazendas em conjuntos habitacionais de removidos de favela e da própria favelização da área. Além da atual conjuntura com a significativa importância das territorializações das facções do tráfico de drogas e das ações das milícias.

Voltamos em dezembro de 2009 e janeiro de 2010, com um conjunto de questões norteadoras. Foram seis vivências na favela (duas em dezembro e quatro em janeiro) todas com um sol de verão carioca e todos os dias com temperaturas acima de $40^{\circ} \mathrm{C}$ e um cheiro de esgoto indescritível. Até que logo no primeiro dia recebi a recomendação de uma moradora: “Tem que naturalizar, meu filho, aqui é assim". Pensei e não conseguia acreditar, pois esse processo que vivenciava era eminentemente social, nada tinha de naturalização. Era algo produzido e não espontâneo. Nos dias posteriores, o constante barulho de vans e kombis do transporte alternativo, de igrejas evangélicas, o calor, o odor eram os menores dos meus desafios. Recebi explícitas recomendações para não fotografar nada, nunca desafiar ninguém 
e se possível, anotar somente quando estivesse na casa de algum morador com contundente consentimento dele. As gravações de algumas entrevistas também foram um desafio. A presença discreta e ostensiva dos traficantes foi outra angústia, pelo menos nesse momento (depois essa relação se modificou completamente, praticamente inviabilizando a continuação dos meus trabalhos de campo, como relatarei adiante). As recomendações supracitadas me foram repassadas por um dos "olheiros" do tráfico (gíria que expressa uma das hierarquias do tráfico de drogas, sendo que os olheiros geralmente são os meninos mais novos que fazem o controle de quem entra e sai da favela), um menino de aproximadamente 15 anos que me chamava de "Professor Botafoguense", devido a minha condição de professor ${ }^{48}$ e também pelo time de futebol que torço. Outra recomendação fundamental recebida era para eu não me aproximar da polícia (alguns moradores se referiam aos policiais como "porcos", outros os chamam de "criminosos de uniforme"), pois eu poderia ficar "queimado" na favela. A expressão "queimado" porta consigo duas conotações: a primeira de ser malquisto pelos moradores (informante do aparato policial ou de um órgão do aparelho do Estado) o que dificultaria minhas conversas e entrevistas, a segunda refere-se a "queimar" no sentido literal. Os traficantes se valem de uma forma muito perversa de extermínio de inimigos e delatores (a gíria para expressar aqueles que delatam as pessoas envolvidas com o tráfico de drogas é " $\mathrm{X}$ 9") denominado "micro-ondas". Esta consiste em colocar a pessoa dentro de um conjunto de pneus, jogar gasolina e depois atear fogo. Essa prática tem uma dimensão material de dificultar o reconhecimento do corpo e uma dimensão simbólica de expressão de força e intolerância de certas atitudes nos territórios dominados por suas ações.

Essa situação e as recomendações fizeram-me refletir que em tempos de agravamento de situações de miserabilidade e do crescimento do exército de reserva, lupemproletariado urbano (ROCHA, 2010) para uns ou do subproletariado (SINGER, 2010) para outros, a criminalização da pobreza faz com que as políticas de segurança se imponham como "guerra" ou mesmo "reconquista do território" sobre o espaço dos pobres, voltando-se repressivamente contra as classes mais pauperizadas. Percebemos que é na atitude combinada de presença de repressão e criminalização e ausência de espaços de sociabilidade (áreas de lazer, escolas, infra-estrutura) deixado pelo Estado que as facções criminosas tornam-se empregadoras de uma parcela de jovens e adolescentes, principalmente, aqueles pertencentes aos grupos sociais mais atingidos pela violência estrutural, conforme observam Rocha (2010) e Nakamura

\footnotetext{
${ }^{48}$ A recomendação de sempre me apresentar como professor foi da Professora Cristiane Mattos. Apesar de no âmbito escolar ocorrer um demérito da profissão e uma precarização do trabalho docente, na favela em que estudei a condição de professor é observada como profissão que denota confiança pelos moradores e pelos traficantes.
} 
(2010). Rocha (2010) ressalta ainda que esses jovens e adolescentes são sujeitos em meio a uma sociedade construída sob a égide de contradições e violências. Esses produzem e, ao mesmo tempo, sofrem em seu cotidiano a interferência de diferentes aspectos da violência. Ressalta-se a importância destacada pelos moradores do espaço de sociabilidade das igrejas evangélicas as religiões pentecostais e principalmente neopentecostais apresentam uma presença maciça nas favelas analisadas.

Recebi o aviso que meu "salvo conduto" fora autorizado, e assim poderia entrevistar algumas pessoas e transitar por uma parte da favela. As minhas visitas poderiam ser guiadas por um morador da favela. Quem acabou sendo meu contato e amigo foi o jovem Rafael. Ele tem 18 anos, cursa o $3^{\circ}$ ano do Ensino Médio em Paciência e é filho da primeira moradora entrevistada, que a professora e amiga Cristiane tinha me recomendado, Sara. Também conheci Jacó, marido de Sara, e a filha mais nova do casal, irmã de Rafael, Maria, de 15 anos, que é aluna de Cristiane em uma Escola Municipal na favela do Cesarão. Rafael não freqüenta a escola no Conjunto Habitacional Otacílio Câmara, a favela do Cesarão, que é mais próxima de sua casa, pois esta encontra-se sob o domínio da facção rival ao Terceiro Comando Puro (que domina territorialmente a Favela das Três Pontes), o Comando Vermelho. Flamenguista fanático, Rafael já treinou na escolinha do Flamengo, e três semanas depois da última vivência que fizemos à favela ele teria uma peneira no Campo Grande Atlético Clube, na qual, descobrimos posteriormente, não passou. Como muitos jovens, Rafael sonha em ser jogador de futebol. Mas percebe que a saída se não conseguir será fazer um curso técnico para trabalhar em alguma indústria em Santa Cruz, assim como seu pai.

Rafael é reconhecidamente o "craque da comunidade". Simpático, extrovertido e amigo de boa parte da comunidade, já viu muitos dos seus amigos que "entraram no tráfico e caíram". Alguns deles permanecem ("os vivos", como ressalta ironicamente). Seu auxílio foi fundamental à pesquisa.

A atmosfera parecia carregada pelas ações policiais que estavam ocorrendo nas favelas da Zona Sul do Rio de Janeiro com a instalação das Unidades de Polícias Pacificadoras ${ }^{49}$

\footnotetext{
49 Os primeiros anos do governo Sérgio Cabral (2007-2008) foram marcados por declarações enfáticas de guerra às facções criminosas (inclusive pelo próprio governador e também pelo secretário de segurança pública conforme ressalta Machado da Silva, [2010]), que transformavam o que até então era uma metáfora (a "guerra ao crime") em política pública e oficial. A repercussão, embora cautelosa e pouco midiática, não foi satisfatória, e o governo rapidamente mudou o discurso. As Unidades de Políticas Pacificadoras (UPP) nascem como resultado invertido da truculência retórica, que exagerava no reconhecimento explícito do que secularmente acontece nos bastidores do controle das "classes perigosas" (MACHADO DA SILVA, 2010), que sempre se realizou através da violência. Inverteram-se os termos: a guerra, isto é, as famigeradas "operações", que estão longe de ter acabado, preparam a pacificação; a guerra deve ser intensa, mas é curta; já a pacificação pode ser lenta, mas é de longo prazo (MACHADO DA SILVA, 2010). Os meios de comunicação de massa veicularam amplamente as ações policiais nas favelas pacificadas. Sendo assim, com a perda de domínio territorial imposta
} 
durante os meses de dezembro de 2009 e janeiro de 2010. Nesse momento, eu não sabia que a situação ficaria muito pior depois da operação policial no Complexo do Alemão no final de novembro de 2010, exatamente no momento em que tentaríamos complementar nossos trabalhos de campo. Os moradores e os traficantes me pareciam incertos quanto à mobilidade de certos chefões do tráfico para as favelas do extremo oeste do Rio de Janeiro.

A Favela das Três Pontes é gerenciada pela facção Terceiro Comando Puro (TCP) e na hierarquia do tráfico é subordinada a Favela do Aço, que se localiza ao lado dela. O TCP é comandado por jovens e funciona em sistema eminentemente hierárquico. As favelas respondem sempre a uma outra favela, onde, geralmente, se localiza o gerente-geral do tráfico. Nessa perspectiva, as Três Pontes, em comparação a Favela do Aço - o ponto central é considerada "tranqüila".

Em vários momentos de conversa uma frase era afirmada "Aqui nas Três Pontes é comunidade, lá no Aço que é favela". Aquilo me parecia ainda bastante abstrato e depois fui compreender os significados dessa assertiva. Naquele momento refleti sobre a conectividade daquela produção do espaço, conflituosa e contraditória, mas também complementar de favelas.

Outro fato digno de nota refere-se a temática da pesquisa. Como meu objetivo na apresentação para os moradores e para os traficantes foi a realização de uma pesquisa sobre as condições de "saneamento básico da favela", principalmente sobre o abastecimento de água, não sofri muitas indagações sobre os porquês da escolha do tema, pois realmente há carência de infra-estrutura e serviços de água. Ou em outras palavras, esse não é um temário que envolvesse dúvidas sobre o meu papel de ser um informante do Estado e da polícia. As indagações vieram quanto a escolha das Três Pontes. "Mas por que veio estudar logo aqui?" como me perguntou Jacó.

Em tempos de agravamento das contradições sociais, a humanidade está a cada dia mais desumanizada, e esta desumanização não é um fenômeno natural, mas sim um processo histórico, decorrente de múltiplas determinações presentes na ordem capitalista (MÈSZÁROS, 2008). O processo de desumanização e mesmo de esquecimento desse fragmento da cidade e dos seus moradores é cabal, concreto.

pela implantação das UPPs, parte dos traficantes dessas áreas migrou para favelas na Zona Norte, Zona Oeste e Baixada Fluminense. Embora tenham refúgio garantido, esses grupos não entram na divisão dos lucros obtidos com a venda de drogas na localidade e, por isso, passaram a atuar em assaltos a bancos e em seqüestros conforme relata Ramalho (2010: 23) 
Além da miséria material, o capitalismo constrói a miséria humana, pois o homem alienado e fragmentado é impedido de perceber-se em totalidade, muito menos, como sujeito histórico e social: são assim considerados desimportantes e descartáveis para o modo de produção, e isso se reflete na consideração de que "esse lugar não vai te trazer nenhuma resposta", como cheguei a ouvir. Assim, contei um pouco da minha história para Jacó e das relações entre as minhas experiências de precariedade do abastecimento de água durante minha infância e adolescência também na Zona Oeste do Rio de Janeiro - meu lugar de nascimento e moradia - e os desdobramentos até chegar a favela das Três Pontes. "Estou aqui para tentar dialogar e fazer com os moradores novas perguntas, buscando nas suas experiências e vivências as respostas que vierem" respondi refletindo.

Fui saber depois que apesar da favela da Três Pontes ter sido escolhida para o Programa Favela Bairro 1, ela era preterida atualmente das políticas públicas que se desenvolviam em outras favelas de Santa Cruz e Paciência. Há então nesse contínuo uma seletividade de ações do poder público em determinadas favelas do entorno, principalmente no Cesarão, mas também no Cesarinho, recebendo infra-estrutura e visibilidade. E ações do chamado desenvolvimento comunitário local na favela do Aço, aquela que "realmente é favela".

Outra questão que nos chamou atenção foi a forte territorialização das favelas. Descobri que onde você mora denota mais que seu lugar de vivências, experiências e vida cotidiana, pois também há um pertencimento referente a relação entre o indivíduo, o território de moradia e as facções do tráfico ou da milícia que domina esse fragmento. O morador de uma determinada favela carrega consigo a territorialização da favela a que pertence, ou seja, as características da favela são "repassadas" aos seus moradores: mais "favelado", ou mais "perigoso", mais "fiel” (gíria que expressa confiança), dentre outras identidades.

Sobre a questão do abastecimento de água, descobrimos que uma parte significativa da Favela das Três Pontes já era abastecida por água pela CEDAE (derivado da adutora da Zona Industrial de Santa Cruz) anteriormente às intervenções do Programa Favela Bairro, porém conforme nos relata Sara, ocorreu também a autoconstrução da infra-estrutura de abastecimento de água.

Aqui era barro puro, era água de poço. A gente morava mais pra dentro, ai meu pai quis mudar aqui para frente. Meu pai morou ali, inclusive no valão que agora passa por aqui, antes ele não passava por aqui, isso foi depois do Favela Bairro, eles fizeram a uns quinze anos atrás mais ou menos. Quando mudamos aqui é que fomos ter água encanada e essas coisas... Lá pra dentro, para as pessoas terem água, eles se juntaram, como por exemplo, meus sogros, porque a CEDAE nunca botou água aqui. Então eles mesmos foram 
quem puxaram, compraram os encanamentos e foram puxando a água cada vez mais para dentro. Ai depois os outros moradores foram puxando e fazendo construções. Mas a conta d'água chega! Só não chega pra mim, porque depois que eu casei, eu peguei a água da minha sogra, eu uso a água dela. A conta vem, mas a CEDAE nunca passou.

Sara nos relata, ainda, a cooptação dos políticos sobre as obras realizadas pelos moradores: "Eles fizeram aqui nas Três Pontes o Favela Bairro, e era favela que ia virar bairro para lá e para cá. Não entendo isso. Bota um asfalto, limpa um valão e isso faz virar bairro? Fizeram o Favela Bairro só por causa do voto. Ai, depois disso, foi só Lucinha [vereadora da Zona Oeste a três mandatos e nas eleições de 2008 a vereadora mais votada da cidade]. Vou botar isso e aquilo... construíram essa quadrazinha, depois de uns anos de novo um reparo no asfalto. Ano retrasado, acho, quando teve eleição, não me lembro. Aí passaram aqui e falaram que foi a Lucinha que botou água aqui. Daí falei assim: o quê?! Ela não mora aqui e não construiu nada, ela tá vindo aqui é agora. Que Lucinha que botou o quê!”

As obras de infra-estrutura de abastecimento de água, segundo exposto pela arquiteta Patrícia Santos (que realizou pesquisas junto à comunidade), restringiram-se a fazer reparos e consertos no encanamento. Todavia, uma "parte da favela" foi incorporada ao projeto, pois não havia encanamentos na área (chamada de Área 5 nos pareceres técnicos, na realidade tal área é denominada pelos moradores como "Paraguai"). A questão foi parcialmente resolvida durante a realização das obras, sendo que a irregularidade no sistema em tal área permanece.

Percebemos que na favela das Três Pontes ainda permanecem as duas grandes formas de abastecimento de água (KLEIMAN, 1996, BUENO, 2000) descritas por aqueles que estudam favelas como os "modelos" de abastecimento anterior a década de 1970-1980, exemplarmente, as ligações clandestinas popularmente conhecidas como "gatos" e a instalação de grandes caixas de água que distribuem o líquido de modo clandestino para os moradores. Os dados oficiais demonstram que 54\% dos moradores que sofreram intervenções de infra-estrutura de abastecimento de água durante o Favela Bairro recebem conta de água nessa favela, o que demonstra que há muita incoerência nos dados acerca da suposta universalização do abastecimento.

As contradições entre os dados oficiais são categóricas: o Censo de 2000 expõe que 100\% dos moradores de Paciência são abastecidos por água e 95\% com redes de água. Já a Prefeitura da cidade do Rio de Janeiro (2005), em defesa das ações do Programa Favela Bairro, retrata que 99\% da favela das Três Pontes está abastecida. O IPP (Instituto Pereira Passos) expõe que não há rede oficial da CEDAE, esta existe apenas em localidades próximas, no bairro de Santa Cruz e em sua Zona Industrial e no centro do bairro de 
Paciência. O que observamos é que o sistema está longe de ser universalizado. Pelo contrário, com o crescimento da favela, construções de novas casas e fragmentação dos terrenos para moradia de familiares, a irregularidade ou a inexistência no sistema só aumenta.

O encanamento de esgoto existente foi também construído por mutirão, e posteriormente seriam construídas várias estações para o seu tratamento, a partir das obras do Programa Favela Bairro. A construção de fato ocorreu, entretanto, não em quantidade suficiente. O destino final do esgoto continua sendo o rio (o "valão da comunidade"). As estações não receberam monitoramento nem manutenção que pudessem garantir os parâmetros do projeto, revelando um quadro de abandono e depredação. O que de fato foi realizado e aprovado pelos moradores são as obras de drenagem fluvial, isto é, a canalização da vala a céu aberto.

Os moradores entrevistados, principalmente Ruth (35 anos, balconista de loja de artigos de R \$ 1,99 em Santa Cruz, mãe, "filha de seu Elias") e Sara (52 anos, dona de casa, mãe, "já fui de igreja [evangélica], hoje não vou, mas sou uma mulher de muita fé”) nos relataram que a questão da resolução das enchentes foi solucionada. Ruth nos relatou comovida como ficou sua casa depois do alagamento em 1992. "Era tanta água, a gente tirava e parecia que não tinha fim. Depois veio a lama, a gente perdeu fogão, televisão, armário”.

A construção de galerias no rio que corta a favela (e que a separa da favela do Paraguai) foi um dos marcos para resolução das constantes enchentes que assolavam a comunidade. Uma área alagada foi drenada e atualmente é utilizada como campo de futebol durante o dia. Durante a noite, a mesma área é utilizada como lugar para emboscada entre traficantes de facções diferentes, para esconderijos e perseguições e para despejo de corpos. E a polícia utiliza-o (poucas vezes) para blitz policiais e muitas vezes para recebimento do arrego do tráfico (gíria que se refere a dinheiro entregue pelos traficantes aos policiais para que esses não realizem operações policiais coercitivas na favela).

Questionei a moradora Ruth sobre em qual lugar gostaria de morar, e ela afirmou: “Acho que todo mundo dirá o mesmo: em Urucânia ou Paciência, lá tem milícia, água na bica, segurança, tem que pagar por tudo isso, é verdade, mas pelo menos fico tranqüila com meus filhos na rua".

A coleta de lixo é outro dado da precariedade. Na área mais próxima à entrada da favela os caminhões de lixo conseguem realizar a coleta. Porém, para áreas mais afastadas da entrada principal a questão é crítica: cacimbas lotadas de lixo e alguns moradores precisam caminhar algumas ruas para depositar seus resíduos em locais determinados. 
Portanto, consideramos que o Programa Favela Bairro avançou muito pouco nas questões estruturais da favelização, apesar de em teoria esse ser um de seus objetivos. A geração de postos de trabalho e renda e a regularização fundiária são questões que não se ouviu falar na favela das Três Pontes, segundo os moradores. O ilustrativo disso é o Programa Favela Bairro ser referido como "a época que se realizaram obras na comunidade", como exposto por Sara. As intervenções privilegiam as obras de infra-estrutura e equipamentos urbanos, principalmente no que se refere a: reparos e consertos em encanamentos de água, esgotamento sanitário, drenagem fluvial e asfaltamento de ruas. A manutenção das obras é inexistente. As redes construídas rapidamente chegaram a saturação e sem reparos. A manutenção dessas redes é ineficiente. Os equipamentos urbanos foram seletivamente instalados pela comunidade e, no caso das Três Pontes, centrado na "área de entrada" da favela (Rua Três Pontes). O interior da favela é precariamente servido, conforme já apontava o IPP (antigo IPLANRIO).

\subsubsection{Paraguai: só quem mora sabe onde é}

O Paraguai, conforme explicitado, é uma espécie de apêndice da favela das Três Pontes, sendo que o rio canalizado as separa territorialmente. O meu "salvo conduto" nas Três Pontes não valia para tal área, mas acompanhado do Rafael consegui adentrar essa parte da favela, em duas visitas realizadas em janeiro de 2010.

O problema do abastecimento de água foi relatado por Esther (mãe de quatro filhos, simpática e muito divertida), uma moradora entrevistada, como um dos problemas centrais. “A água aqui é um sofrimento, meia-noite, uma hora eles abrem, quando são quatro horas da manhã eles fecham. Quem tem caixa-d'água nesse tantinho enche, quem não tem fica sem água mesmo, carrega da biquinha. Lá para dentro, parece que já tem quatro meses que não se vê uma gota d'água. Quatro meses sem água nenhuma, carregando daqui de baixo um galão até em casa para poder beber".

Ela me relatou sua visão sobre a favela do Paraguai: "Isso aqui está esquecido meu filho, ninguém quer saber de favela não, só quem mora sabe onde é”.

Relatou-nos ainda a negação por parte do Poder Público e a tensão de morar numa área de "fronteira" entre as facções do tráfico de drogas. "Aqui no Paraguai tá tudo errado, não somos das Três Pontes, aquelas obras que aconteceram lá quase não chegou nada aqui. Aqui não somos do Cesarinho, parece que vai ter uma Clínica da Família lá, pelo menos é perto, mas aqui ainda temos muitos problemas..." Pergunto quais: "saúde, educação, 
saneamento, insegurança, água, que cai dia sim, dia não, não e não. (...) a saída é pegar água no vizinho que tem bomba [hidráulica]".

Apesar dessa favela ter sofrido intervenções para a construção de infra-estrutura de água, a precariedade da prestação do serviço é imensa. Os moradores do Paraguai de partes mais distantes da entrada da favela estavam a meses sem o abastecimento regularizado. $\mathrm{O}$ dono de uma padaria da favela afirmou que precisava comprar galões de água para continuar sua produção. A imagem que observamos em uma das visitas era a seguinte: uma considerável quantidade de pessoas, principalmente mulheres e crianças, com baldes e galões de água nas mãos se abastecendo em uma bica na entrada da favela e caminhando vários metros até suas casas, armazenando água para saciar a sede, tomar banho, cozinhar.

Uma senhora de passo apressado e olhar desconfiado com um filho a tira colo me falou depois da minha tentativa de aproximação sobre o que significava uma vida sem água: "temos que guardar água em casa, faz muito tempo que não sei o que é ter água em casa. Beber essa água direto não dá, tem que ferver a água de casa todo dia. Mas o gás está caro... não dá para esquentar tudo, não é mole não...A vida aqui é pior que de gado, pelo menos o boi tem água na sua cocheira". Meus olhos marejaram. No pesquisador também corre sangue, lágrimas e crítica, e a sistematização desse trabalho de campo foi um dia difícil da nossa pesquisa. Essa metáfora permaneceu insistentemente em minha mente.

$\mathrm{Na}$ territorialização do tráfico de drogas, todavia, essa área é parte integrante do TCP. No mês de março de 2010, depois da minha visita a favela Paraguai, ocorreu o domínio da milícia sobre a Favela do Cesarinho, e tais favelas são fronteiriças. Em novembro e dezembro de 2010, quando retornamos, a tensão na favela do Paraguai estava elevada e não consegui passar da entrada.

Não poderia me fixar apenas nessas duas favelas. Decidi que deveria pesquisar esse contínuo urbano de precariedade e os significados e desdobramentos da presença-ausência do Estado nessas favelas, e na mesma semana me encaminhei até a favela do Aço.

\subsubsection{Favela do Aço: a "renovação" do arquétipo da favela}

Consideramos a favela do Aço como a renovação do "arquétipo da favela", conforme proposto por Valladares $(2000)^{50}$. O imaginário da favela, no qual está imbricado as relações

\footnotetext{
${ }^{50}$ Valladares (2000: 43-44) afirma que "uma favela específica serviu como arquétipo, como base de construção de um tipo ideal, passando a inspirar toda a produção intelectual relativa a esse espaço: o morro da Providência, logo denominado morro da Favella. A dualidade cidade/favela tem sua gênese nesse período fundador, quando a favela é vista como território máximo da precariedade tanto física quanto social que se opõe ao restante da cidade, à sua ordem e à sua população. Aglomeração percebida como temporária, transitória, é, no entanto, logo
} 
entre a ilusão da transparência e a ilusão da opacidade, com infra-estrutura, equipamentos e serviços precários, violência, venda explícita de drogas, presença de traficantes procurados pela polícia, aparato policial conivente com as ações do tráfico, bailes funk constantes, presença de terceiro setor na realização de projetos fugazes e a presença constante no noticiário policial em casos envolvendo assassinatos, extermínios, seqüestros. A favela contém todas essas dimensões.

Na hierarquia do TCP, o chefe do tráfico de drogas da área de Santa Cruz se encontra na favela do Aço. A venda de entorpecentes é realizada de modo explícito em várias bocas de fumo. O baile funk mais famoso das favelas dessa área, com a presença dos astros do funk do momento, e realizados pelas equipes (empresas ${ }^{51}$ que realizam bailes funk) Furacão 2000, pela Big Mix e Glamourosa fica instalado lá. Os políticos, ao buscar votos, escolhem primordialmente tal favela. Os problemas de infra-estrutura, porém, são vários, como redes precárias e ligações clandestinas. A favela é também lócus de ações de desenvolvimento local comunitário $^{52}$ realizados principalmente por ONGs e também respaldados por projetos de universidades.

reconhecida pelos primeiros observadores como detentora de valor econômico e, como tal, explorada mediante a cobrança de aluguel do "chão" ou dos barracos. (...) Pude constatar, também, que nem a idéia hoje amplamente generalizada de as favelas resultarem da invasão de terrenos, nem a hipótese da favela como solução de moradia barata para os pobres urbanos estavam presentes nesse período fundador. Assim como também não havia a idéia de os favelados serem maciçamente oriundos das correntes migratórias que trouxeram os nordestinos para o Rio. Os habitantes de inúmeras favelas desse período inicial eram imigrantes estrangeiros pobres — portugueses, espanhóis, italianos - que precisaram enfrentar a crise da moradia no começo do século. Ou correspondiam a uma população que havia povoado inicialmente o cortiço mas que, de fato, era fruto da reprodução da pobreza originária do Rio de Janeiro. Muitos jovens que hoje se interessam pelo estudo da favela ignoram a contribuição de seus antecessores e escrevem como se estivessem pela primeira vez descobrindo este espaço e seus moradores".

${ }^{51}$ A Associação de Profissionais e Amigos do Funk (APAFUNK) criada em 2008 para lutar pelos direitos dos funqueiros e contra a associação entre funk e violência realizam profundas críticas ao monopólio do mercado e ao asfixiamento da diversidade do funk, e são contundentes em denunciar o cartel formado pelas empresas do DJ Marlboro (equipe Big Mix) e de Rômulo Costa (Furacão 2000). Os empresários, hoje milionários, controlam não apenas a produção e distribuição, mas também os mecanismos de difusão. Os principais programas de rádio e TV de vinculação do funk também são controlados por eles. Nos contratos com os artistas, a exploração é de dar inveja aos maiores empresários da história da música nacional (FACINA e LEONARDO, 2009). No contrato relativo ao fonograma, por exemplo, enquanto Marlboro cobra 96\% do valor, entregando apenas $4 \%$ ao artista (ou à dupla), Rômulo cobra $100 \%$ dos lucros. Vitalício, o contrato é imposto como documento padrão. A exploração é reproduzida também nos shows, onde ambos ficam com o lucro quase total. "Você não vê o dinheiro voltar para a favela, onde estão os artistas. Não se ganha dinheiro" protesta MC Junior. (FACINA e LEONARDO, 2009)

${ }^{52}$ Para Pfeiffer (2001), o desenvolvimento local/comunitário articula a idéia de "empoderamento" de grupos de pessoas em "desvantagem social", que compartilham de uma mesma localização geográfica, como a melhoria das condições concretas de vida desses mesmos grupos de pessoas. Fontes (2009) e Petras (2001) ressaltam o processo de cooptação das ONGs e as estratégias de desenvolvimento social local comunitário. Estes afirmam que desde a década de 1980, os governos americanos e europeus financiam mediante fundações privadas e fundos estatais as atividades de ONGs que expressam uma ideologia contra o Estado (PETRAS, 2001) e promovem ações de "alívio à pobreza" (FONTES, 2009). Na realidade, as ONGs recebem doações de governos ou funcionam como agências subcontratadas por governos locais. Outro fato é que seus programas não são qualificados pelas "comunidades" a quem "ajudam", e sim pelos financiadores externos. Ainda que as ONGs 
Então, consideramos que a favela do Aço é um "laboratório de experiências" para um conjunto de projetos financiados por recursos privados e públicos, na estratégia da mundialização do capital que são as "parcerias". Constatamos um conjunto de projetos, tais como: o realizado pelo Centro de Promoção da Saúde - CEDAPS ${ }^{53}$ (2002) para "promoção da saúde" e que serve como referência. Este projeto foi iniciado com o intuito de contribuir para "o aumento da cidadania e a geração de trabalho e renda na região" que está entre "os menores Índices de Desenvolvimento Humano do município do Rio de Janeiro". O projeto contou com financiamentos/participações da Dreyfus Health Foundation, do HSBC, do Ministério da Saúde e da Secretaria de Estado de Trabalho do Rio de Janeiro. A partir dessa ONG surgiu a Iniciativa de Vila Paciência (IVP). Este é um “programa territorial” (BECKER et. al.; CEDAPS, 2002) baseado nos pressupostos do desenvolvimento local comunitário - e sustentável -, (compreendendo e reafirmando constantemente que há possibilidade de sustentabilidade dentro do modo de produção capitalista) e na promoção da saúde ${ }^{54}$. Sua estratégia consiste em "envolver os moradores no processo de desenvolvimento, por meio de diagnóstico comunitário e planejamento coletivo, mobilização e capacitação, formando uma rede de soluções comunitárias para problemas sociais”. Tal iniciativa já foi concluída.

Outro projeto que constatamos foi o que se realizou na produção de energia térmica por meio de biogás, "sintetizado a partir de resíduos sólidos provenientes das habitações, de um restaurante industrial e de matrizes suínas em Vila Paciência” (SILVA, NAVARRO e ALMEIDA, 2008:2) a partir do "Projeto de Desenvolvimento Local e Auto-sustentável de

tenham denunciado violações aos direitos humanos, raras vezes denunciam seus benfeitores (PETRAS, 2001). $\mathrm{Na}$ realidade, as agências multilaterais e as administrações de cunho neoliberal aproveitaram as ONGs para minar o sistema de seguridade social estatal, que foram utilizadas e reduzidas em meios para compensação das políticas privatistas. Fundaram-se ONGs para promover projetos de desenvolvimento social local que absorveriam, temporariamente, pequenos grupos de desempregados pobres, ao mesmo tempo que recrutavam lideranças locais para seus projetos de empreendedorismo comunitário e corporativo. As ONGs se converteram então na "face comunitária" do neoliberalismo e se relacionam intimamente com as agendas e pautas definidas pela burguesia internacional (PETRAS, 2001). Ao incorporar os pobres na economia neoliberal através de ações voluntárias que são eminentemente relacionadas a iniciativa privada, as ONGs criam uma estrutura em que há a aparência de uma solidariedade e ações sociais que ocultam uma conformidade com as estruturas de poder. Não é por acaso que as ONGs têm-se convertido em entidades dominantes em certas regiões onde o ativismo social tem decaído e o neoliberalismo rege através de ampla coerção (PETRAS, 2001).

53 O Centro de Promoção da Saúde é uma ONG que tem como missão (no sentido atribuído pela responsabilidade social corporativa) desenvolver a autonomia e a capacidade de "comunidades populares" para buscar soluções para seu desenvolvimento, e contribuir para a melhoria de serviços que atuam nestas localidades, de modo a promover saúde e qualidade de vida. Ele atua calcando-se na cidadania e na construção de políticas públicas em prol das "populações desfavorecidas", buscando a emancipação e o "empoderamento" dos atores sociais locais. Para tal intento, investe no fomento à realização da cidadania via construção de empreendedores com responsabilidade social.

${ }^{54}$ Ressalta-se todo o vocabulário dessas iniciativas eminentemente articuladas a um discurso empresarial de doutrina neoliberal. Aparecem constantemente nos discursos e textos: atores, atuação, promoção, capacitação, gerência, missão, visão, estratégia, marketing, riscos, empreendedores, empreendimentos, responsabilidade social, responsabilidade empresarial, sustentabilidade, desenvolvimento local, etc. 
Vila Paciência" vinculado a Universidade Federal do Rio de Janeiro iniciado e também já encerrado. A conclusão a que chega tal projeto é que o "problema que a humanidade enfrenta é viver melhor, consumindo menos e regenerando a qualidade do meio ambiente (...), [então] dinamizando a economia local gera-se um processo de 'aceleração evolutiva" Tal projeto na favela do Aço teria a "potencialidade" de realizar tais prerrogativas.

Outra entidade do terceiro setor que "atuou" na favela do Aço é o Centro Integrado de Estudo e Programas de Desenvolvimento Sustentável (CIEDS). Suas ações foram iniciadas e concluídas no ano de 2003 e consistiam na realização de "formação comunitária" baseada na “capacitação gerencial de lideranças comunitárias, através da realização de Curso de Formação de Empreendedores Sociais, envolvendo suas etapas de planejamento, operação e gestão, que habilitem os participantes a se associarem em empreendimentos sociais, que promovam o desenvolvimento das comunidades" (CIEDS, 2004: 4).

Nota-se que a favela do Aço é chamada principalmente pelas iniciativas de desenvolvimento local comunitário de "Vila Paciência" (CEDAPS, 2002; ALMEIDA, SILVA e NAVARRO, 2008; CIEDS, 2004; BECKET et al., 2004; PFEIFFER, 2001; DIAGNÓSTICO SÓCIO-AMBIENTAL COMUNITÁRIO DE VILA PACIÊNCIA, 2009), "com o objetivo de superar o estigma do nome" (segundo informação da professora Isabel de Geografia de um CIEP da comunidade). Ela relata ainda que paulatinamente os moradores começam a utilizar essa nomenclatura, porém não identificamos essa realidade.

Há ainda por parte dos moradores das favelas do entorno a identificação de que a favela do Aço é sim uma favela. "O pessoal mais beneficiado com projeto é lá do Aço. Olha a história de uma central de informática: fizeram uma pesquisa para abrir aqui, fizeram entrevista, para contar as crianças que seriam beneficiadas com inscrição e tudo mais. Na hora abriram no Aço. Foi para lá, as crianças não tem o que fazer, volta da escola e faz o quê (..) Aqui nas Três Pontes é comunidade, lá no Aço é favela. Eles vêm de lá pra cá, sabe, são uns favelados". (Sara, moradora das Três Pontes). "Se aqui é favela? É... pode-se dizer que sim, mas favela mesmo é lá no Aço". (José, morador do Cesarão).

Nossa entrada na favela foi realizada através de trabalhos de campo no CIEP, escola pertencente à favela do Aço (a professora Isabel foi nossa interlocutora em dois trabalhos de campo na favela do Aço) e a partir dessa escola conseguimos chegar aos dados. O que nos chamou especial atenção foi o desenvolvimento por parte da escola do "Diagnóstico sócioambiental comunitário da Vila Paciência". O diagnóstico foi realizado através de aplicação de questionários para levantar os problemas sociais e ambientais da "comunidade", uma etapa da chamada "Agenda 21 escolar desse CIEP". Para tal empreitada foram aplicados 220 
questionários, com 27 perguntas, com a ajuda dos alunos do Ensino Fundamental, sendo duas turmas do $6^{\circ}$ ano, duas turmas do $7^{\circ}$ ano e outras duas do $9^{\circ}$ ano. Os estudantes levantaram o perfil social, a ocupação, profissão, renda e escolaridade dos moradores. Depois fizeram um diagnóstico ambiental, descobrindo qual é o destino do lixo, como é feito o seu recolhimento, quais os cuidados tomados pela população. Além das condições de abastecimento de água e de esgotamento sanitário da favela.

Percebeu-se no diagnóstico que a maioria dos entrevistados abandonou a escola antes da $8^{a}$ série e a que favela não possui saneamento ambiental. "Agora não dizemos mais saneamento básico, e sim ambiental. (...) Embora exista um gari comunitário, o lixo da região é despejado em valas e terrenos baldios. O esgoto é in natura, ou seja, a céu aberto", conforme nos explicitou a professora Isabel.

Outro fator que chamou a atenção da professora foi a questão do serviço de abastecimento de água. A água utilizada pela favela do Aço é advinda de ligações clandestinas e os tubos passam em paralelo à rede de esgoto, que não tem tratamento. Isabel conta-nos que "qualquer furinho que você tem no tubo propicia a contaminação por coliformes fecais".

Após o levantamento realizado pelos alunos, uma série de ações foi proposta para melhorar a "qualidade de vida" dos moradores. Essas ações serão implantadas na volta às aulas (ou seja, em tese seriam realizadas ao longo do ano de 2010). "O projeto vai se chamar ‘100\% água, uma questão de cidadania"”, segundo nos relatou a professora. Entre as ações propostas estão uma palestra no posto médico com um profissional da área de Saúde para explicar à população a importância de se usar água tratada. Serão distribuídas 200 pastilhas de cloro para quem possui caixa d'água e 50 torneiras com filtro.

Isabel relatou que internamente identificam-se duas áreas distintas: a Parte Baixa, onde ficam os "vagões", como é chamada pelos moradores, e a Parte Alta, chamada pelos moradores de "dialta", onde ficam os blocos, os conjuntos habitacionais. Por ter sido um conjunto planejado (inicialmente para ser provisório) pelo governo do Estado, nos anos 1960, a favela é considerada um conjunto habitacional por parte dos órgãos públicos, dificultando o acesso a programas de melhoria em favela. (CEDAPS, 2002).

Os vagões são módulos contíguos de 15 metros quadrados cada, sem divisões internas, que ficam um de frente para o outro com uma distância de aproximadamente 2,5 metros entre eles, formando uma série de vielas onde o esgoto se rompeu. Quando chove, a água se mistura nas torneiras com o esgoto. As tampas dos bueiros não existem mais. 
Rosemeire Maia (2010), analisando as modificações do padrão construtivo nos conjuntos habitacionais e favelas da Zona Oeste, coletou uma entrevista que expõe o poder do tráfico sobre a propriedade:

Aqui, quem mora nos vagões [referindo-se aos embriões que foram destinados pela Prefeitura à população vitimada pelas enchentes ou transferida de favelas situadas em áreas nobres] tem dificuldades de fazer alguma melhoria, pois as casas são geminadas, uma do lado da outra (como vagões mesmo!!!), sem quintal. E também ninguém gosta de se arriscar a gastar dinheiro numa coisa que não é dono. Aqui, o traficante é que diz quem é o dono. Ele pode expulsar qualquer um a qualquer hora e colocar outra pessoa no lugar. Por isso fica tudo deste jeito mesmo. Ninguém melhora nada (moradora da favela do Aço entrevistada por MAIA, 2010: 101).

Essa situação expõe como o tráfico de drogas regulamenta inclusive a vida privada dos moradores da favela, além de subjetivamente instaurar o receio de possíveis expropriações pela ação dos traficantes. A interferência dessas "lideranças" - sejam os traficantes, sejam os milicianos que, cada vez como maior frequência, se impõem à habitação e a vida cotidiana do proletariado urbano - é constatada na "organização" do espaço público ou no estabelecimento de uma rede de serviços paralela, como formas de manter/justificar sua ação, ou mesmo receber apoio (ou silêncio) da população. Maia (2010), Mamede (2005) e Machado da Silva (2010) expõem, de pontos de vista diferentes, que a ação dos traficantes se estende ao espaço privado, interferindo em dissensos familiares, "dando exemplo" em maridos violentos, expulsando pessoas de suas casas e confiscando bens, ou seja, estabelecendo normas e regras de conduta social e moral.

Segundo a pesquisa amostral realizada pelo CEDAPS (2002) na favela do Aço, da população de 15 a 59 anos, apenas 32,7\% trabalham, formal ou informalmente. Desses entrevistados 70,1\% tinha de 20 a 49 anos. Dos que trabalham, apenas $48,2 \%$ possui carteira assinada. (CEDAPS, 2002)

Em suma, a favela do Aço concentra índices precários de condições de vida da reprodução, possuindo raros equipamentos sociais, áreas com sérios problemas de saneamento e limpeza urbana, moradias com grande precariedade, situações de coerção violenta, um ativismo social submetido a lógica do terceiro setor, influência do tráfico de drogas, rivalidade com facções do tráfico de drogas e de milícias (com maior grau de articulação interna), dificultando a circulação e o acesso a direitos sociais básicos e equipamentos públicos do entorno (DIAGNÓSTICO SÓCIO AMBIENTAL COMUNITÁRIO DE VILA PACIÊNCIA, 2009). 


\subsubsection{Cesarão: a favela que tem tudo}

Estivemos no Cesarão em junho de 2009, realizando três trabalhos de campo. Cristiane Mattos é professora da escola municipal localizada em tal favela, o que possibilitou a nossa visita. Também realizamos pesquisa na Associação de Moradores (em janeiro de 2010 em uma única visita, esta carregada de tensão, pois me sentia sendo vigiado durante todo o curto diálogo com o representante da Associação). Estava inquieto com a afirmação de Ruth, moradora da favela das Três Pontes, que me parecia uma contradição entre os termos e que acabou me levando a tentar (re)conhecer a favela do Cesarão: "enquanto aqui na favela do Aço é uma precariedade, no Cesarão tem tudo. É a favela que tem tudo".

Nas conversas com professores e alunos durante os dias que freqüentei suas aulas e o cotidiano da escola (ainda em junho de 2009) descobri que Cesarão é o nome popular de um conjunto habitacional construído ao final da década de 1970 com aproximadamente sete mil unidades.

O mesmo tem por nome oficial "Conjunto Otacílio Câmara". Foi construído pela Companhia Estadual de Habitação do Rio de Janeiro - CEHAB - e está localizado à margem da Avenida Cesário de Melo e da Estrada da Pedra, que possibilita acesso rodoviário aos bairros de Santa Cruz, Campo Grande e Barra da Tijuca, principais lugares de trabalho dos moradores. Sua localização e seu acesso contribuem para sua definição como centralidade.

A moradora Ana, funcionária de uma escola municipal, relatou-nos que a área onde foi construído o conjunto era uma imensa chácara com plantações de laranjas. Com o passar dos anos, a área foi "abandonada por seus antigos donos". No Cesarão foram construídas "um sem fim de casas" segundo Ana. Na realidade 5.667 casas, como aponta Valladares (2006). Atualmente esse número é muito maior, pois em quase todas as casas foram construídas outras, desmembrando-se os terrenos ou mesmo verticalizando a construção.

Os conjuntos habitacionais, embora pensados pelos arquitetos modernistas no início do século XX como uma alternativa visando a democratização da cidade, a racionalização dos espaços e a provisão de equipamentos comunitários (a medida em que se voltariam para os segmentos trabalhadores que, até então, ocupavam favelas ou áreas pauperizadas), não chegaram a ter este caráter na cidade do Rio de Janeiro, onde tal modelo passou a ser implementado a partir da década de 1960, conforme expõe Maia (2010). A autora observa que ao se resgatar a história da constituição dos conjuntos habitacionais observa-se uma história de expropriações dos moradores de seus antigos locais de moradia (favelas das áreas nobres e centrais ou "áreas de risco", com sua controversa definição de significados) e de precariedade da infra-estrutura nos locais aonde foram postos, além da perda das redes de sociabilidade, 
como observou Menegat (2006). Esses processos são particularmente exemplares em Santa Cruz e especialmente no Cesarão, que foi durante muito tempo considerado o maior conjunto habitacional da América Latina.

As primeiras obras para a construção do Cesarão foram realizadas no início do ano de 1979. As casas tinham padrões diferentes: embrião (sala, cozinha e banheiro) para trabalhadores de baixa renda; casa (quarto, cozinha, sala e banheiro) e apartamento duplo (2 quartos, sala, cozinha e banheiro) para funcionários de média renda. Os apartamentos não se adequavam ao tamanho das famílias, e o que se observa ao se caminhar pelo Cesarão são moradias que pouco lembram sua arquitetura original, mas habitações multifamiliares e partes da casa transformados em negócios, como expôs Maia (2010) e como observamos em trabalhos de campo. Esses fenômenos nos parecem ser explícitos na favela do Cesarão, pois a impossibilidade do urbano demonstra sua aparência real: a impossibilidade de adquirir a propriedade da moradia especialmente para os filhos e parentes dos moradores de conjuntos habitacionais que se casam ou tem filhos. Tal fato se manifesta na grande quantidade de habitações multifamiliares e a crise do trabalho se expressa nos pequenos negócios que estão em várias moradias da favela, como lan house, pequenos comércios, pequenas vendas, bazares, barraquinhas de venda de alimentos, bares, etc.

No ano de 1980 foram entregues "as chaves para as famílias", e no mês de maio de 1981 foi inaugurado o conjunto. Devido ao tamanho da área, o Conjunto foi dividido por setores, 1, 2 e 3, conforme exposto pelo representante da Associação de Moradores do Conjunto Residencial Otacílio Câmara.

Há no Cesarão uma ocupação, de cerca de 30 famílias, denominada Nova Palestina. A ocupação foi mobilizada por antigos militantes do MTST (Movimento dos Trabalhadores Sem-Teto) quando o movimento ainda tinha sede no Rio de Janeiro (conforme expõe MAMARI, 2008: 77). Sua ocupação foi realizada em 2007. Seus militantes pertencem a partidos políticos e foram os responsáveis pela escolha do local.

O Cesarão possui 10 igrejas evangélicas, 2 igrejas católicas, 5 centros espíritas, 1 posto de saúde (Unidade de Pronto-Atendimento - UPA), 1 Centro Social Urbano (CSU), 1 posto policial, 1 Centro de Cidadania, 2 Escolas do $1^{\mathrm{o}}$ segmento do ensino fundamental, 2 CIEPs ( 1 de ensino fundamental e outro de ensino médio), 1 Escola de Ensino Médio e outra de Ensino Fundamental, 2 Jardim Escola, 3 creches, 2 áreas de lazer, 4 campos de futebol, 1 Centro de Apoio comunitário onde funciona um Centro Educacional para crianças de 3 a 5 anos, 1 Biblioteca Comunitária, 1 Projeto de Prevenção contra a AIDS, 1 quadra de esporte (essa quadra foi reservada pela antiga Telerj com a intenção de ser um Clube Familiar, e hoje 
é utilizado como área de lazer da comunidade), salões de cabeleireiro, padarias, mercadinhos, muitos bares, ou biroscas como são chamados.

No Cesarão foi construída ainda uma Clínica da Família e a Escola de Basquete de Rua do Cesarão, projeto do jogador Wanderson Geremias, campeão nacional de basquete de rua em 2008 no torneio organizado pela Liibra (Liga Internacional de Basquete de Rua).

Assim, compreendemos que há um processo de construção de centralidade na favela do Cesarão, para onde convergem projetos da iniciativa pública e privada de caráter permanente. Contudo, há inúmeros problemas relatados que a favela sofre, como tráfico de drogas, ausência de esgotamento sanitário e a recorrente presença de redes de abastecimento de água ineficientes no atendimento da favela. Foi constante a reclamação no Cesarão de que a "água chega fraquinha na casa". Ou seja, a vazão de água que atende a favela é aquém das demandas. Porém, não se pode afirmar que o quadro do saneamento no Cesarão em relação ao abastecimento de água seja tão precário quanto as outras favelas analisadas.

Pensar numa ação seletiva na produção do espaço pela racionalidade técnica e burocrática do Estado leva-nos a alguns debates propostos por Marques (1996) para contrapor alguns argumentos sobre a questão do saneamento. $\mathrm{O}$ autor enfatiza que, durante a segunda metade da década de 1970, investir na construção de um sistema de abastecimento para a Zona Oeste passou a ser uma alternativa realizada também pelas escolhas de técnicos da CEDAE. Para Marques (1996), essa burocracia estava interessada em reproduzir suas posições de poder (individuais e da companhia), acreditando ser importante incorporar os fragmentos do espaço habitados pela população pobre aos sistemas operados pela CEDAE. Não se trata de dizer que não ocorreu segregação sócio-espacial na distribuição dos investimentos em saneamento, visto que as coberturas para as periferias em 1980 (e mesmo em 1990) permaneciam muito abaixo das verificadas em outras áreas da cidade. Trata-se de compreender dialeticamente que a segregação não é completa e perfeita, e que em certos momentos ocorreram inversões de vulto impossíveis de se explicarem, partindo unicamente dos pressupostos excludentes da política de saneamento da época (MARQUES, 1996; VETTER \& MASSENA, 1981). Porém, diferente de Marques (1996) percebemos que apesar da segregação não ser completa, o processo de inserção na cidade é precária e o Estado vai funcionar como o Estado de exceção tendo em vista a reprodução da metrópole tendo a economização dos territórios como lógica primeira e final. 


\subsubsection{Cesarinho: da casa para o barraco, do tráfico para a milícia.}

A favela do Cesarinho, à época do trabalho de campo, era dominada pela facção Comando Vermelho, e no mês de março de 2010 foi dominada pela milícia. O Cesarinho tem a produção do seu espaço fortemente atrelada à história do Cesarão (a nomenclatura já expõe tais inter-relações), seguindo a dinâmica clássica da cessão de direitos a terceiros (VALLADARES, 1980). Com o dinheiro recebido, os moradores saldavam a dívida com o BNH (extinto Banco Nacional da Habitação) e saíam do conjunto habitacional que moravam, no caso o Cesarão, e ocupavam/compravam um barraco, formando o Cesarinho.

Realizamos algumas observações nos arredores da favela, pois há uma proximidade entre o Paraguai e o Cesarinho. Há um continuum de precariedade de saneamento entre essas favelas. A questão do esgotamento sanitário é mais evidente com as valas de esgoto e os rios poluídos identificados como "valões". Porém, conversando no bar da entrada da favela do Cesarinho, a senhora que me atendeu argumentou conforme consta em meu caderno de campo: "aqui falta água todo dia, mas o cano que leva água para a comunidade vive furado, vazando".

Depois de uma animada conversa sobre a história da construção dos conjuntos habitacionais, dos processos de favelização e loteamento de Santa Cruz e Paciência, dialogamos sobre a regularização dos serviços de água e esgoto. A simpática senhora de 60 anos ("mas ninguém diria que tenho essa idade" e que "cuida do bar desde que o seu marido morreu") afirmou que boa parte da infra-estrutura construída foi por ação dos moradores: "se tiver que bater uma laje, o povo se junta e põe a casa para cima, se o problema é do esgoto vão lá e colocam uns canos, se não tem luz ou não tem como pagar faz um gato, com a água é a mesma coisa". O tráfico que regula(va) as ações dos moradores, pois "eles sabem de tudo que acontece por aqui”.

Porém, os moradores relataram que a passagem da favela do domínio do tráfico de drogas para milícias foi violento em seu início, mas depois pouca coisa mudou. Souza (2010) argumenta que nos últimos anos, as "milícias" que operam na metrópole do Rio de Janeiro intensificaram a expulsão de traficantes de várias favelas e também a venda de "proteção" à população pobre, estabelecendo padrões de intimidação e extorsão que já chegaram, inclusive, a alguns bairros da chamada "cidade formal". O autor aponta que há a possibilidade das "milícias" representarem um outro patamar do capitalismo criminal-informal no Rio de Janeiro, no que se refere ao comércio de drogas de varejo e a outras atividades econômicas: em vez de apenas extorquir traficantes, policiais e ex-policiais passaram a desterritorializar o 
aparato policial e a operar, eles mesmos, diferentes tipos de negócios ilícitos, em alguns casos atuando em algumas favelas inclusive no tráfico de drogas.

Também do ângulo (sócio)político a ascensão das "milícias" vem representando um novo e grave momento na história do Rio: diferentemente dos "esquadrões da morte" de épocas passadas, os "milicianos" de hoje largamente se autonomizaram, não se contentando em prestar serviços para comerciantes de periferia ameaçados por pequenos bandidos e assustados; passaram, eles mesmos, a operar sistematicamente negócios, com base na territorialização (controle espacial) exercido sobre certas áreas e suas populações. (SOUZA, 2010)

Os milicianos já começaram a eleger seus próprios homens de confiança para exercer mandatos legislativos. Certos candidatos ligados as ações das milícias fizeram campanhas ostensivas em todas as favelas dominadas, inclusive no Cesarinho. Um deles tinha como mote de campanha a questão do saneamento. A contradição entre o discurso de campanha e a prática é explicita, pois seus articuladores na campanha cobram dos comerciantes uma porcentagem na venda de água em garrafão. O jornal O Globo noticiou as atividades das milícias na Zona Oeste do Rio de Janeiro e as conversas dos milicianos no processo de extorsão de comerciantes: "A partir de agora, é tudo comigo. Eu quero quatro reais por cada botija de gás e um real por cada galão de água vendido. Vou colocar um funcionário meu aí dentro, para conferir quantas botijas de gás e quantos galões de água serão vendidos (...) se não pagar, (...) vai virar meu inimigo (...) se não pagar, não vai trabalhar e, se trabalhar, vai virar meu inimigo. Se você acha que não tem que pagar, vou te falar: vai tomar prejuízo" (RAMALHO, 2010).

\subsubsection{Antares: de habitação provisória à cotidianidade da ausência de infra-estrutura}

As décadas de 1960 e parte da década de 1970 marcaram decisivamente a vida e a história das favelas na cidade do Rio de Janeiro. Como relatam Mamede (2005) e Bueno (2000), o Programa de Remoções, iniciado com o governo de Carlos Lacerda e mantido até 1974, primeiro governo de Chagas Freitas, atingiu 80 favelas e 139.218 moradores. Foram construídos e ocupados 35 conjuntos habitacionais, em sua grande maioria, localizados no subúrbio da cidade, Zonas Norte e Oeste. Um total de 48.985 unidades habitacionais.

O Rio de Janeiro é um exemplo de como a remoção de favelas pode ser absolutamente lucrativa para o capital financeiro-imobiliário. Como em outros locais do Brasil, essa ação foi parcialmente bem sucedida, conforme Bueno (2000) relata extensamente. Foram liberados grandes terrenos de interesse para o mercado imobiliário incorporar e vender, em áreas valorizadas da cidade, enquanto outras favelas continuavam a surgir ou expandir-se. A 
expropriação da população das favelas para os conjuntos em áreas periféricas foi analisada em diversos estudos (VALLADARES, 1980; SANTOS, 1979; PERLMAN, 1979) demonstrando que grande parte dos moradores vendia a nova unidade e retornava à favela, por diferentes razões, entre elas a incapacidade econômica de pagar pela moradia, o custo socioeconômico de morar longe do emprego e da infra-estrutura urbana e a busca de um aumento da renda, mesmo que temporário, através da venda.

O último conjunto a ser oficialmente ocupado foi o localizado na Avenida Antares, região limítrofe entre Santa Cruz e Paciência. Tal conjunto não era como os outros construídos no período, não somente por sua situação estrutural ser melhor ou pior, mas por seu objetivo inicial, como argumenta Mamede (2005). Antares não é um conjunto habitacional. Tecnicamente, é chamado de Unidade de Integração Social (UIS) ou um Centro de Habitação Provisória (CHP) ou mesmo Conjunto de Triagem de Antares, como expõe Mamede (2005). Isto significa dizer que as pessoas que inicialmente foram removidas para lá teriam uma estadia provisória, enquanto aguardavam suas casas ou apartamentos definitivos, em conjuntos construídos para lhes servirem de moradia. Ou seja, a primeira de outras remoções. Concluído em 1973, o conjunto seria ocupado dois anos depois, em janeiro de 1975. E em condições subumanas para seus moradores.

O CHP de Antares não contava com água ou luz, muito menos pavimentação. Mamede (2005) resgatou a história dos moradores mais antigos que costumam dizer que os poucos pontos de luz eram os lampiões que eram acesos com querosene e a água provinha de um poço construído por eles próprios. Para Antares foram removidos moradores da Praia do Pinto, pessoas que aguardavam casas no conjunto de Cidade de Deus, removidos da Cidade de Deus, moradores do Vidigal, da Rocinha e de outros conjuntos habitacionais que aguardavam sua moradia definitiva. Entre os anos de 1977 e 1978 passaram a ocorrer ocupações das residências e as unidades habitacionais começaram a ser comercializadas por aqueles que ocupavam. Antares, durante a década de 1980, teve um movimento de associação de moradores bastante atuante, o que trouxe inúmeras melhorias nas precaríssimas condições de vida no conjunto (MAMEDE, 2005). Apesar de bastante controversa nas suas práticas, sem dúvida a Associação conseguiu articular com o Estado o atendimento de demandas. O quadro de retrocesso do ativismo social tem em Antares uma marca bastante explícita, principalmente na década de 1990 como dissertou Mamede (2005). Esse panorama está associado a precarização do trabalho e o aumento do poder das facções do tráfico de drogas.

A favela de Antares não foi propriamente apresentada por ninguém. Nas visitas realizadas durante os meses de dezembro e janeiro de 2010 saíamos das favelas e pegávamos 
o trem na estação de Paciência. Tal estação não era a mais próxima, mas havia uma explícita recomendação dos entrevistados que somente em último caso deveríamos utilizar a estação de Tancredo Neves, que se situa "dentro" da favela de Antares, e primordialmente no horário que os trabalhadores a utilizam. Numa visita resolvi tomar o trem às 7h30min em direção a Santa Cruz. Quando desci descobri "o shopping do tráfico" (gíria para denominar essa estação de trem, pois em sua plataforma e em suas imediações acontece a venda de entorpecentes). A estação é bastante depredada, sua única saída direciona-se aos “fundos da favela". Cristiane já havia nos relatado que a situação seria absolutamente tensa.

Nossa hipótese, quase uma conjectura, é que devido a primazia do rodoviarismo, as favelas e conjuntos habitacionais são construídas na extensão da Avenida Cesário de Melo, "de costas" para a ferrovia, sendo que sua "parte final" encontra-se com a linha férrea. O modelo de construção do subúrbio carioca, isto é, urbanização em decorrência das ferrovias, não se aplica a essa realidade em questão.

Assim, a favela encontra-se relativamente próxima da Avenida Cesário de Melo e "os fundos" da favela próximo da estação. Pontos de venda de drogas são instalados em áreas estrategicamente camufladas. Assim, o panorama é que a parte mais repleta de tensões da favela é exatamente próxima da estação. Foi um dos momentos de maior temor da pesquisa. $\mathrm{O}$ que se escutava: "Pó de $\mathrm{R} \$ 25,00$ reais, cocaína de $\mathrm{R} \$ 30,00$ ”. Em cada rua um pouco mais ampla havia barricadas para evitar a entrada da polícia. Eu seguia as pessoas que se direcionavam para as ruas mais amplas e que desceram comigo na estação. Foram 500 metros de tensão, além de esgoto a céu aberto e moradias precárias.

\subsubsection{Urucânia: a milícia e a coerção violenta e econômica}

O Conjunto Habitacional Maestro Olímpio dos Santos, popularmente conhecido como "Urucânia" devido a Estrada de mesmo nome que serve de referência para a localização, foi inaugurado em 1980 pelo Governo do Estado do Rio de Janeiro, com cerca de 3.000 residências, inicialmente para abrigar famílias sorteadas com financiamento habitacional. Hoje com mais de 5.000 construções em seu entorno há uma população de 35.000 habitantes. O local pertence oficialmente ao bairro de Paciência, segundo consta nas informações obtidas no Armazém de Dados do IPP. Nossa entrada na favela se realizou através da Associação de Moradores União das Bases de Urucânia e Adjacências, na qual foram realizados dois trabalhos de campo em janeiro de 2010. O Conjunto Urucânia é dominado por milícias e, apesar dos inúmeros conflitos e problemas, nos foi indicada por Ruth e Sara, entrevistadas nas 
Três Pontes, como um dos locais em que gostariam de morar devido à oferta de serviços, infra-estruturas e segurança, muitas delas “oferecidas pelas milícias”.

O fenômeno das milícias, organizações de caráter privado no combate ao tráfico de drogas e que cobram proteção aos moradores deliberando ações que antes competiam apenas ao Estado, disputando o domínio territorial com as facções do tráfico de drogas (MOTA e LOPES, 2009; SILVA, FERNANDES e BRAGA, 2008) em bairros do município do Rio de Janeiro, se expandiu. Tal fenômeno influiu na explicação da segregação sócioespacial no que diz respeito à reprodução das desigualdades sociais e na sociabilidade das favelas (MOTA e LOPES, 2009: 1-2).

O controle territorial, coerção e lucro não diferenciam a milícia de outros grupos armados, como o narcotráfico, por exemplo. Os traços mais marcantes são: o discurso de legitimação e a participação dos agentes públicos. O discurso de legitimação relativo à proteção dos habitantes é um ponto central da milícia.

Ela se apresenta como proteção contra a ameaça do crime, contra a desordem e, em última instância, contra o mal, simbolizado na figura do narcotraficante. Diferentemente do tráfico, que não precisa de legitimação, o que se justifica pela simples violência, a milícia não pode se apresentar como um grupo a mais do crime organizado. Tem que se apresentar como alternativa ao narcotráfico. Tenta assim se legitimar pelo seu oposto, como um - mal menor (RELATÓRIO FINAL DA COMISSÃO PARLAMENTAR DE INQUÉRITO DESTINADA A INVESTIGAR A AÇÃO DE MILÍCIAS NO ÂMBITO DO ESTADO DO RIO DE JANEIRO, 2008: 37).

O impacto crescente do poder paralelo nos processos de organização, participação social e política nas "comunidades de baixa renda do município do Rio de Janeiro" levou alguns pesquisadores (principalmente alguns secretários de segurança pública, delegados, comandantes de batalhões de polícia militar e chefes de polícia) a afirmar que a saída para os conflitos apontava para o hobbesianismo social (MOTA e LOPES, 2009), ou seja, uma sociedade onde a segurança e a confiabilidade se reduzem ao estrito âmbito privado e os indivíduos são obrigados a defender a sua propriedade com a sua própria força, contribuindo para o surgimento de grupos armados que disputam um domínio territorial sobre algumas áreas da cidade.

Desde 2005, a milícia realizou em várias localidades da Zona Oeste carioca, principalmente nos bairros de Campo Grande, Santa Cruz e adjacências, a extorsão de comerciantes (como vimos, por exemplo, com proprietários de depósitos de gás e de água mineral), a título de "taxa de segurança". Sob pena de serem impedidos de circular ou de terem seus veículos incendiados, motoristas de vans, cobradores e cooperativados do 
transporte alternativo eram forçados a pagar "diárias" ou "taxa de incêndio", conforme pesquisado e confirmado em trabalhos de campo.

Valendo-se de violência ou ameaças exercidas com o emprego de armas de fogo, os milicianos também impunham a moradores e comerciantes o monopólio na redistribuição de sinais de programação de emissoras de TV a cabo, o chamado "gatonet", ou "skymiau". Além disso, praticavam espancamentos, seqüestros, torturas e assassinatos de integrantes da milícia rival e daqueles que atrapalhassem seus interesses.

Em Urucânia as taxas em janeiro de 2010 eram cobradas por serviço: segurança de moradores $\mathrm{R} \$ 10,00$; de comércio entre $\mathrm{R} \$ 50,00$ e $\mathrm{R} \$ 250,00$; sinal de TV a cabo $\mathrm{R} \$ 30,00$ a mensalidade e R \$ 50,00 a instalação; gás $\mathrm{R}$ \$ 38,00; barracas $\mathrm{R}$ \$ 10,00; galões de água: RS 5,00 , conforme nos foi informado pelo entrevistado que identificaremos, por pedido do mesmo, apenas como 'A'.

A milícia que domina territorialmente o Conjunto Urucânia é a Liga da Justiça e o líder dos milicianos é o ex-deputado Natalino José Guimarães (vulgo "Mata-Rindo", atualmente preso). As reuniões entre os milicianos ocorrem no estabelecimento Piscina Bar, na Rua 25 do Conjunto Urucânia conforme nos foi exposto por 'A'.

Ignácio Cano apud Relatório Final da Comissão Parlamentar de Inquérito destinada a Investigar a Ação de Milícias no Âmbito do Estado do Rio de Janeiro (2008: 43) afirma que a milícia tem um grau de organização superior ao do tráfico. Cadastros, reuniões, recibos, cuidado e valorização das armas em função do seu valor instrumental e não simbólico. Essas características revelam um tipo de dominação mais "moderno". Reconhece que a diferença entre milicianos e traficantes não é absoluta e que isso fica bastante claro nos excessos e arbitrariedades cometidas por milicianos. Tais premissas foram constatadas em trabalho de campo. O que nos chamou especial atenção foi a dinâmica financeira da milícia: pode-se constatar que a coerção econômica exercida pelas milícias se estabelece pela coerção (violenta) dos moradores a pagar: taxa de segurança, taxa diferenciada para moradores que possuem veículos, taxa de instalação e mensalidade dos serviços de sinal de TV a cabo e Internet, controle e ágio na venda de gás e garrafão de água, cobrança de alimentos para composição da cesta básica para os milicianos, taxa que varia de 10 a 50\% do valor da venda de imóveis, taxa para legalização de imóveis, taxa para permitir construções na comunidade, controle e cobrança de taxas do transporte alternativo: mototáxi, vans e kombis, cobrança de taxa para funcionamento de barracas de camelô, festas e pipoca e cobrança de instalação de portões e guaritas nas comunidades. (RELATÓRIO, 2009: 125-126). 


\subsubsection{Favelas do Rollas 1 e 2: a passagem contraditória do campo para cidade. Uma "grande favela" no Programa Favela Bairro 2}

A Favela do Rollas na realidade se constitui em duas favelas, Rollas 1 e Rollas 2. As favelas são cortadas pela linha férrea. Sua história é marcada por uma ocupação bastante antiga, conforme verificado na análise de Mamari (2008: 44-45) sobre ocupações de sem teto na metrópole fluminense ${ }^{55}$.

Na década de 1930, após a morte do proprietário da Fazenda Rollas, a fazenda foi ocupada. A área foi toda dividida e foram desenvolvidas práticas de plantio coletivo. Com a “implosão" do rural e a explosão "metropolitana", a área foi subdividida e atualmente conta com mais de 30 mil moradores. Santos e Fernandes (2007) reconstroem essa passagem contraditória do campo para a cidade no Rio de Janeiro. Sinteticamente, constatamos que os autores relatam que na década de 1920 e 1930 os distritos de Santa Cruz, Guaratiba e Campo Grande respondiam por significativas produções agrícolas da cidade do Rio de Janeiro: grandes fazendas e sítios (este de produção eminentemente do pequeno lavrador). Porém, tal área da cidade foi alvo nas décadas de 1950 e 1960 dos avanços dos loteamentos das Companhias Imobiliárias, que se dava em ritmo cada vez mais acelerado devido ao parcelamento de grandes glebas de terras. Alterou-se profundamente a produção do espaço da Zona Oeste. Essa década ficaria sendo conhecida como o período da "febre imobiliária" (SANTOS e FERNANDES, 2007). As companhias imobiliárias investiam em loteamentos de dimensões gigantescas. Muitos desses loteamentos foram considerados "irregulares" e outros clandestinos, para onde, conforme já explicitado no capítulo 2, o proletariado urbano se deslocou. Nas décadas de 1960, 1970 e 1980 ocorreu a construção de conjuntos habitacionais para abrigar os removidos de favelas, juntamente com o crescimento do processo de favelização. As décadas de 1990 e 2000 expõem a consolidação de tal processo.

No ano 2000 as duas favelas foram beneficiadas pela segunda etapa do Programa Favela Bairro (Favela Bairro 2).

\footnotetext{
${ }^{55}$ Mamari (2008: 74) expõe que embora ainda ocorram ocupações na Zona Oeste (como a supracitada Nova Palestina no Cesarão), as ações principais de ocupações acontecem no centro da cidade. $\mathrm{O}$ autor apresenta duas hipóteses para essa virada: a "visibilidade" das reivindicações em áreas centrais na busca de moradias, principalmente prédios públicos vazios, a partir da bandeira da reivindicação do direito à moradia digna através do reconhecimento da posse, da concessão real de uso, ou da propriedade plena. Essas ocupações são geralmente articuladas por movimentos autogestionados. Estar no centro significa, também, mais atenção e proteção contra repressões policiais, o que estimulou tais ações. Na Zona Oeste ocorre o contrário: as ocupações estão sujeitas a repressões policiais, além de repressões pelas facções do tráfico e das milícias e há, ainda, carências de infraestruturas e serviços.
} 
Originalmente destinado ao atendimento às favelas de porte médio, o programa se desdobra, na segunda gestão (2000-2005), em dois outros: o Bairrinho (entre 100 e 500 domicílios) e Grandes Favelas (acima de 2.500 domicílios), que, com objetivos similares aos do Programa Favela Bairro 1, buscam ampliar a escala das intervenções.

Os investimentos no Favela Bairro 2 também foram de US\$ 300 milhões, sendo US\$ 180 milhões do BID e US\$ 120 milhões da contrapartida local. Esses recursos tornaram-se ainda mais importantes durante a segunda gestão, principalmente para o Bairrinho e o Grandes Favelas.

$\mathrm{Na}$ segunda etapa do programa, uma iniciativa financiada com recursos da União Européia, ainda em caráter piloto, visava construir uma intervenção de caráter social que antecedesse e acompanhasse as obras. Um convênio assinado em 1998 entre a prefeitura e a União Européia criou o programa de Apoio às Populações Desfavorecidas da Região Metropolitana do Rio de Janeiro (APD-Rio), tendo por objetivo a melhoria das condições de vida dos moradores de cinco favelas inseridas no programa Bairrinho.

Porém, as obras do Programa Favela Bairro 2 ficaram inconclusas, inclusive nas Favelas Rollas 1 e 2. A construção da rede de água e esgoto nas favelas não se realizou. $\mathrm{O}$ prefeito Cesar Maia atribui os problemas à queda do dólar, que segundo ele, exigiu a revisão de algumas situações:

- A queda do dólar mudou a relação de financiamento (do BID) e aporte da prefeitura. $\mathrm{O}$ valor em reais flutua com o câmbio. Este caiu de $\mathrm{R} \$ 3,4$ para $\mathrm{R} \$ 2,10$ e reduziu fortemente o valor dos recursos aplicados - explicou, minimizando os efeitos da demora. - O cronograma continua a tempo. O governo é de quatro anos. Se o Favela Bairro 3 tivesse sido antecipado, teríamos que acelerar o 2. Como não foi, podemos administrar e ganhar tempo torcendo para que o câmbio suba e os recursos externos subam com ele (ENGELBRECHT, 2006).

Porém, conforme nos relatou (de forma indireta) uma arquiteta da Secretaria de Habitação, as obras pararam, pois ocorreu um escoamento de investimentos da Prefeitura para o Pan-Americano de 2007. Ou o "foco da gestão" foi o atendimento das demandas de preparação da cidade para os Jogos, conforme ela nos expôs.

\subsubsection{Divinéia: uma urbanização de favelas (Favela Bairro 1) após o convênio com o BID - tecendo comparações}

A favela da Divinéia sofreu intervenções pelo Programa Favela Bairro 1 em obras que conforme explicitado nos dados oficiais desencadearam o desalojamento de parte da comunidade. Sua entrada no Programa foi posterior a favela das Três Pontes, iniciando-se as 
obras após o convênio entre a Prefeitura e o BID, quando ocorreram intervenções importantes relacionadas à implantação de uma rede viária na favela, e também de infra-estrutura de saneamento.

Faz-se necessário retomar a questão do Programa Favela Bairro e retomar alguns momentos de institucionalização dessa política. A primeira referência ao Programa se encontra num documento denominado "Bases da Política Habitacional da Cidade do Rio de Janeiro", cujo texto, aprovado em 1993 em reunião do GEAP (Grupo Executivo de Assentamentos Populares) e presidida pelo prefeito da cidade, relatava a necessidade de complementar ou construir a estrutura urbana que consideravam principal, no caso saneamento e democratização dos acessos, nos termos do documento e oferecer condições ambientais da interpretação da favela como bairro, conforme consta em Bessa (1997) e Randolph et al. (1997). A questão passava pela morfologia, ou intervenções que modificassem a paisagem das favelas, o que como uma base para políticas de habitação nos parece preocupante.

Em 1995, especificamente no dia 7 de novembro do mesmo ano, cria-se por decreto o PROAP (Programa de Urbanização de Assentamentos Populares do Rio de Janeiro), articulando os programas de urbanização de favelas (Favela Bairro) e a regularização da propriedade privada da terra (Programa Regularização de Loteamentos), o que consolida a institucionalização do Programa Favela Bairro e passa a considerar ambos programas como as chaves fundamentais da política habitacional da cidade.

O PROAP é a consolidação dos acordos firmados entre a Prefeitura e o BID. A consolidação do programa irá significar uma ampliação em vários níveis: 1) do tamanho e a projeção do Favela Bairro, 2) do volume do capital e 3) da ingerência do BID nas ações de políticas públicas do município. Randolph (1996) expõe que com a parceria com o BID três componentes irão se articular à urbanização de favelas e à regularização da propriedade: monitoramento e avaliação; educação sanitária e ambiental e desenvolvimento institucional.

Arantes (2007), ao analisar as estratégias do BID e do Banco Mundial nas políticas urbanas, salienta como ocorrem os ajustes urbanos que esses bancos ao atuarem nas cidades procuram implementar e associar essas ações aos ajustes econômicos estruturais. Os programas inovadores são os que forjam os novos paradigmas de ação pública, para os quais os bancos multilaterais pretendem ativamente "colaborar". São também os que dão mais "visibilidade", quesito fundamental para as novas estratégias de city marketing e publicidade das "marcas" dos bancos. As considerações dos "gestores públicos" são de que o recebimento de empréstimo dos bancos "é referência de inovação ao projeto (...) dá projeção ao programa" 
conforme expôs a arquiteta entrevistada da Secretaria Municipal de Habitação. Essa intencionalidade foi explicitada por Arantes (2007), pois o BID e o Banco Mundial foram capazes de associar às suas marcas os conceitos de inovação, modernidade e solidariedade. Um esforço que durou décadas e teve altos e baixos todas as vezes que as instituições foram acusadas de patrocinar catástrofes sociais e ambientais.

O PROAP e a instituição de um caderno de encargos expressaram mudanças significativas em relação à concepção original do Programa Favela Bairro. A tendência apontada no relatório "Avaliação Institucional do Programa Favela Bairro: a vertente do Poder Público" do IBAM (Instituto Brasileiro de Administração Municipal) em 1996 se confirmou ao longo dos anos e do desenvolvimento do Programa. A centralidade inicial do projeto na dimensão urbanística, mesmo que de uma certa morfologia da paisagem, foi substituída por intervenções em infra-estrutura e saneamento ao sabor do perfil dos projetos que o BID prioriza, e é nesse contexto de modificações institucionais que as ações e intervenções na favela da Divinéia se inserem. O caráter altamente intervencionista é uma marca das ações do Programa Favela Bairro, e no caso da Divinéia uma área foi removida para a construção de ruas, retirando casas e barracos de alguns becos e vielas. Tecnicamente várias obras previstas pelo Programa já foram concluídas, como relataram os moradores.

Porém, na favela da Divinéia há uma insatisfação com as obras de urbanização de favelas de modo intenso. Essa favela foi uma das favelas onde mais pessoas falavam criticamente sobre as ações do Poder Público: criticou-se as obras de esgoto, abastecimento de água, coleta de lixo, o calçamento, etc. Além disso, vários moradores reclamaram da qualidade dos materiais, do serviço, da infra-estrutura e da obra realizada na favela.

\subsubsection{Nova Jersey: "novas" perspectivas de urbanização de favelas ou quando uma política pública morre (Rio Comunidade, a ilusão do Favela Bairro 3 e o Programa Morar Carioca)}

Nova Jersey é uma favela dominada territorialmente pela facção Amigo dos Amigos. Conforme discursou o Prefeito Eduardo Paes em visita a favela Nova Jersey, outras favelas serão beneficiadas pelo Favela Bairro $3^{56}$. O que foi considerado pelos moradores como uma

\footnotetext{
${ }^{56}$ Em entrevista, Jorge Bittar, Secretario de Habitação da cidade do Rio de Janeiro, afirma a Lima (2009) que "A solução passa, de um lado, pela urbanização das favelas, como vem fazendo o governo do Estado, e pela produção de novas moradias, sobretudo para a população mais pobre". Em agosto de 2009 se anunciou a retomada do programa Favela Bairro, com a renovação do contrato com o BID, paralisado desde 2005, e o trabalho conjunto com os governos estadual e federal. "Estamos juntos em Manguinhos e no Alemão. De nada adianta o Estado entrar com UPPs (Unidades de Política Pacificadora) no Dona Marta, por exemplo, se a
} 
sinalização de que a favela podia ser uma das beneficiadas com a reativação do Programa. Ledo engano, pois o Programa Favela Bairro, marca da gestão Cesar Maia, foi encerrado. As ações centrais da administração do Prefeito Eduardo Paes estão se pautando numa modificação político-administrativa baseada no choque de ordem, nas UPP's, na construção de um novo Planejamento Estratégico, na revisão do Plano Diretor e no âmbito geral o alinhamento político-eleitoral entre Prefeitura e Governo do Estado e a União, o que em muito fez com que o aparelho de Estado da Prefeitura "focasse" suas ações no Programa de Aceleração do Crescimento para as favelas (o denominado PAC das Favelas). Nos projetos que se referem à urbanização de favelas, a Prefeitura do Rio de Janeiro "reativou os trabalhos" do Programa Rio Comunidade, fazendo com que o Programa Favela Bairro, marca da administração anterior, fosse sendo esquecido.

Criado em 2001 pela Prefeitura do Rio de Janeiro, sob a gestão da Coordenadoria Geral de Obras, o Programa Rio Comunidade tem como objetivo atuar em comunidades desprovidas de infra-estrutura e saneamento básico, em especial nas Zonas Norte e Oeste. Os trabalhos objetivam a requalificação destas comunidades, com a implantação de rede de drenagem de águas pluviais, pavimentação de logradouros, construção de meio-fio, sarjetas e passeios, e urbanização geral da comunidade. No período de 2001 a 2008 foram executadas aproximadamente 80 obras dentro do Programa Rio Comunidade, com 500 logradouros atendidos, beneficiando uma população de mais de 80.000 moradores, com um total de mais de R\$ 100 milhões de recursos investidos pela Prefeitura em valores atualizados (SECRETARIA MUNICIPAL DE OBRAS, 2010).

As intervenções na Favela Nova Jersey foram orçadas em R \$ 3,9 milhões, e começaram a ser realizadas em setembro de 2008 pela Prefeitura municipal do Rio de Janeiro, por meio do programa Rio Comunidade. Suas obras foram concluídas com a pavimentação de ruas, construção de infraestrutura de drenagem, infraestrutura de abastecimento com a participação da CEDAE e a construção de sete vias, o que ocasionou a remoção de pessoas para outras partes da favela, segundo consta na Secretaria Municipal de Obras (2010). A favela Nova Jersey, quando estivemos em campo em dezembro de 2010, estava ainda com uma impressão de término de obras. Havia ainda uma expectativa de que as obras fossem apenas o início de algumas modificações sobre aquela área. Uma das questões relatadas é que "estava muito caro morar em Nova Jersey depois dessas obras" como nos disse uma jovem

Prefeitura não recolhe o lixo, cuida da iluminação e da manutenção de equipamentos. É fundamental também ir além do Favela Bairro com programas sociais". 
moradora. Brinquei que aquele era um estado componente dos Estados Unidos e que o padrão de vida da homônima pobre estava se encaminhando para esses padrões. Está caro morar na favela, pois as infra-estruturas construídas oneram ainda mais as famílias. Contas de água, luz, esgoto, telefone, além dos gastos com transporte fazem com que boa parte da renda esteja comprometida. A inserção pontual na favela Nova Jersey foi particularmente tranquila, apesar das operações bem próximas. Porém, resolvi transitar e conversar apenas na entrada da favela durante os meses de novembro e dezembro de 2010, pois havia uma especulação de que os policiais poderiam ocupar essa favela.

O programa Favela Bairro, segundo o discurso oficial, já tem um sucessor na administração de Eduardo Paes. O Programa Morar Carioca (Plano Municipal de Integração de Assentamentos Precários Informais) é um plano que pretende nos próximos dez anos ser a política pública para a urbanização de todas as favelas da cidade. Nessa nova empreitada as favelas estão sendo recontadas, e ressalva-se que a "contagem" está sendo realizado por meio de imagens de satélites e vetorização de seus limites. Novamente o aparelho de Estado analisa o espaço como aquele que pode ser concebido para as ações de esquadrinhamento e ações de planejamento urbano submetido à técnica e às intervenções. Muita coisa mudou na aparência: o nome, a forma, os coordenadores, e algumas propostas, mas a lógica e a gênese permanece a dimensão urbanística voltada para a reprodução do capital e da metrópole, com fundamento na propriedade privada, na mundialização do capital e na intervenção na morfologia da paisagem. Vejamos como tal análise se explicita ${ }^{57}$.

O Programa Morar Carioca foi lançado oficialmente no final de julho de 2010 e sua proposta é urbanizar todas as favelas até 2020. O “novo programa” custará R\$ 8 bilhões, e todas as favelas terão gabarito fixado e limites demarcados, além de serem alvos de choques de ordem em caráter permanente, por meio da Secretaria de Ordem Pública. As favelas que forem consideradas em "áreas de risco" e não forem urbanizadas serão removidas até 2012. Sob esse critério (critério?), serão removidas 123 favelas. Moram nessas favelas 12.973 famílias, porém a Prefeitura já admite que o número de expropriados pode ser (bem) maior. No discurso oficial, os removidos de favela que no "novo" jargão moram em áreas "não urbanizáveis" serão transferidas para imóveis populares do programa Minha Casa, Minha Vida. O número das famílias que poderão se beneficiar com o programa federal de habitação ainda é impreciso e muito obscuro.

\footnotetext{
${ }^{57}$ Tais considerações se explicitam nas reportagens realizadas por Jungblut e Magalhães (2010) - "Maior parte da sobra no orçamento com empréstimo do Bird será investida no programa Morar Carioca" - e em Bastos (2011) - Segunda fase do Morar Carioca prioriza favelas perto de áreas olímpicas.
} 
O Morar Carioca será um dos programas que receberão a maior parte das verbas que sobrarão no orçamento com o empréstimo de US\$ 1,045 bilhão (cerca de R\$ 1,9 bilhão) no Banco Mundial (Bird). Os recursos serão repassados à Secretaria do Tesouro Nacional para amortizar a dívida que a cidade tem com a União, possibilitando a redução dos juros cobrados. Com essa operação, segundo o prefeito Eduardo Paes, sobrarão no orçamento cerca de R \$ 400 milhões por ano, que serão empregados nas áreas de saúde, educação, urbanização e gestão do município (JUNGBLUT e MAGALHÃES, 2010).

A cidade do Rio de Janeiro tem atualmente um nível de endividamento público vultoso: por exemplo, o empréstimo com a União tem fim somente em 2029. Enquanto o empréstimo com o Banco Mundial vai até 2040 (JUNGBLUT e MAGALHÃES, 2010).

Porém, esse capital a juros tem suas contrapartidas: o Bird firmou o contrato com a Prefeitura com o explícito comprometimento de amplas reformas fiscais. Uma das cláusulas do contrato é aumentar a idade mínima para a aposentadoria dos professores. Também tem que estar nos planos do município a construção de escolas de ensino fundamental em favelas em áreas de conflito e a garantia da eficiência dos serviços públicos (sinônimo de tentativas de privatização, de diminuição de verbas para dimensões fundamentais da vida da população principalmente a mais pauperizada, desemprego para trabalhadores, aumento das parcerias publico-privada, como já observamos em diferentes análises).

\subsection{A dimensão violenta e a coerção no espaço urbano: o pesquisador se depara com um novo momento da barbárie capitalista}

Um parêntese precisa ser aberto para discutirmos os significados da dimensão violenta das ações do Estado sobre as favelas no Rio de Janeiro, particularmente do seu aparelho repressivo, mas não se bastando nele.

Nos trabalhos de campo, as operações e incursões policiais no Complexo do Alemão em novembro de 2010 influenciaram decisivamente nas entrevistas, diálogos, experiências e vivências nas favelas que pesquisei. Alguns traficantes de favelas do Alemão se deslocaram para outros locais e alguns deles para a Zona Oeste. A população estava temerosa com essa situação e também receosa em contatos e entrevistas. O pesquisador estava bastante inseguro também. O clima de otimismo midiático ficou concentrado nas classes médias e altas, que inclusive no chamado "Dia D" das operações lotaram as praias da Zona Sul carioca. A atmosfera do deslocamento de chefes do tráfico para as favelas na Zona Oeste não corroborava com a "pacificação" amplamente difundida. Posteriormente a essas ações ocorreram uma série de incursões em favelas dominadas, principalmente, pelo Comando 
Vermelho e pela facção Amigos dos Amigos. Realizei inúmeras tentativas de reestabelecimento de contatos, que na maioria das vezes foram negados.

Várias das nossas intenções de pesquisa mais aprofundadas em áreas no interior das favelas pesquisadas foram comprometidas. Pois, depois das "operações" no Complexo do Alemão, a polícia começou uma série de incursões sobre favelas buscando os chefes do tráfico, também nas favelas da Zona Oeste, como por exemplo, prendendo o chefe do tráfico das favelas Rollas 1 e 2 e Antares e "buscando" aqueles traficantes que estariam supostamente escondidos nessas favelas. Essas "operações" pouco divulgadas ou repercutidas pela mídia foram opressivamente violentas: helicópteros, veículos blindados (conhecidos na gíria das favelas como "caveirão") e uma infinidade de policiais liderados pelos policiais da Coordenadoria de Recursos Especiais (Core) e de cinco delegacias especializadas da Polícia Civil. Outro papel dessa operação denominada de "Conexão Antares" teve a intenção de desarticular as relações existente entre os traficantes das favelas do Rollas 1 e 2 e de Antares com o Complexo do Alemão e da Penha. Esses complexos de favelas são grandes distribuidores de drogas para as favelas dominadas pelo Comando Vermelho no Rio de Janeiro.

Os discursos posteriores à desterritorialização dos traficantes de drogas de varejo (venda a retalho de drogas) da favela da Vila Cruzeiro (25 de novembro de 2010) e do Complexo de Favelas do Alemão (três dias depois), na Zona Norte do Rio de Janeiro, ficaram expressos como a "reconquista do território" e outras equivalentes e passou a ser fartamente referenciada por diferentes agentes do aparelho do Estado. O que muito se difundiu foi a idéia de que "as comunidades voltaram a pertencer ao Estado" e que a "ordem novamente se instalava" nesses locais agora pacificados. Muitas interpretações sobre as ações policiais surgiram nesse momento, porém Alves (2010) e Souza (2010) foram as análises que mais amplamente foram debatidas. Alves (2010) retratou esse momento como um rearranjo da geopolítica do tráfico de drogas do Rio de Janeiro.

Para Souza (2010) o fato é que as "comunidades" nunca "pertenceu" ao Estado.

Embora largamente desassistida e, obviamente, bastante estigmatizada pela classe média e pelo próprio Estado e pela grande imprensa, a tutela estatal, exercida de modo que em geral mesclava (ou alternava) a brutalidade (arbitrariedades da polícia) e o clientelismo mais rasteiro, não deixou de se fazer presente. Apesar de serem as favelas largamente desassistidas em matéria de provimento de serviços básicos e infraestrutura técnica e social, uma frase como "o Estado sempre esteve ausente [das favelas]" é retórica e politicamente compreensível, mas, em última instância, pouco rigorosa. (SOUZA, 2010) 
Souza (2010) analisa que o Estado sempre lançou os seus tentáculos sobre os espaços segregados. Porém, a relação vai mais além: o Estado mantém com a população moradora de favelas, a contradição permanente entre presença e ausência deliberada. As incursões permanentes da polícia, ou por meio das malhas do clientelismo, como por exemplo as bicas d'água, são demonstrações de presença. Por outro lado, cada vez mais, ao longo dos anos 1980, mas mais ainda a partir da década de 1990, a tutela do Estado passou a ser disputada e teve de se arranjar com o poder exercido pelos chefes do tráfico de varejo, pequenos representantes do capitalismo criminal-informal (SOUZA, 2010; NAKAMURA, 2011; MISSE, 2009) que sofrem e atuam violentamente (ROCHA, 2010).

Souza (2010) argumenta que no decorrer das décadas, os traficantes de varejo, sistematicamente extorquidos por policiais, passaram a se arranjar com os agentes do Estado também de várias outras maneiras: intermediação entre políticos (ou candidatos) e as favelas, em época de eleição ou não; interferências menos ou mais "toleradas", "negociadas" cotidianamente, junto a programas governamentais, como o Favela-Bairro (urbanização de favelas), com a finalidade de evitar intervenções que pudessem causar estorvos à segurança ou aos negócios dos traficantes; ligações com organizações não governamentais, dentre outras formas. Não chegaram, contudo, ao ponto de se organizarem para eleger seus próprios representantes junto às câmaras de vereadores ou à Assembleia Legislativa (SOUZA, 2010). Essa prática é realizada pelas "milícias" conforme explicitado no Relatório da "CPI das Milícias".

Preocupamo-nos em compreender de modo um pouco mais aprofundado a dimensão violenta das ações do Estado nas articulações entre o capital financeiro e o tráfico de drogas. Nakamura (2011), por exemplo, expõe tais relações. Ao retratar o tráfico de drogas, o autor disserta sobre um comércio global que movimenta mais de 400 bilhões de dólares por ano e que é a base da economia de diversos países que não conseguiram a entrada na dinâmica da acumulação capitalista considerada "legal". Explicita que o tráfico de drogas funciona imbricado à lógica da(s) empresa(s) transnacional(ais). O tráfico só pode se movimentar mundialmente estabelecendo vínculos estreitos com as atividades legalizadas: os bancos participam da lavagem de dinheiro; mercado da segurança cresce no compasso do discurso do medo (seguranças privados, venda de armas, carros blindados, alarmes para residências etc.), os agentes do Estado vendem o que Misse (2009) chama de "mercadorias políticas" - a "segurança" para as ações do tráfico e a garantia da permanência do controle da venda de drogas mesmo quando presos, laboratórios químicos vendem os componentes químicos das drogas, latifúndios produzem maconha e coca (NAKAMURA, 2011). E que inclui uma 
imensa massa de pessoas que foram rifadas do circuito de trocas "legal": camponeses pobres, traficantes que fazem as drogas circularem no varejo, "mulas" que transportam drogas entre os países, e outros.

Estima-se que o tráfico no Rio de Janeiro (cocaína, maconha e crack) fatura entre 316 a 633 milhões de reais por ano, mas lucra algo em torno de 130 milhões por ano, pois os traficantes precisam arcar com os altos custos de logística de fornecimento, proteção do território, "pedágios" ou "arregos" para policiais corruptos e perdas nas operações de busca e apreensão feitas pela Polícia Militar. Como explicar o suposto levante de traficantes cariocas no final do mês de novembro de 2010? Calcula-se que o tráfico teve um prejuízo de 30 milhões de reais com a apreensão de drogas e armas. Suicídio financeiro não é bem a cara da vida criminal. (NAKAMURA, 2011)

A idéia de pacificação, libertação e democratização da favela foi o que ficou amplamente difundido pela mídia. Assim como a escolha dos que poderiam ser descartados, assassinados e esculachados como enfatiza Nakamura (2011). Mas são os homens armados em fuga e o aparato bélico do Estado os protagonistas do espetáculo, em narrativa estruturada pelo viés maniqueísta da "guerra" entre o bem e o mal.

Como o "inimigo", jovens negros, pobres, com roupas e chinelos falsificados empunhando armas que mal conseguem carregar e moram na favela, são seus moradores que sofrem os efeitos colaterais da "guerra", enquanto a crise parece não afetar tanto assim a vida na zona sul, onde a ação da polícia se traduziu no aumento do policiamento preventivo. A violência é desigual.

O que estamos tentando apontar é que se combatem os chamados "fora-dalei" desrespeitando a lei, para que se abra o espaço para atividades também fora-da-lei, como é o caso dos grandes eventos esportivos. O que as pessoas estão chamando de necessidade da intervenção do Estado nos morros cariocas, é a necessidade da instalação de um capitalismo de gângsteres encoberto por nossa atual conjuntura de crescimento econômico. (NAKAMURA, 2011)

Aponta-se ainda para a instalação de vetores de ações e intervenções estatais que conformam uma parte da cidade como a "Cidade Olímpica", isto é, o Rio de Janeiro para o turismo internacional e para o city marketing na Zona Sul, Barra da Tijuca e no eixo CentroZona Norte com centralidade no Maracanã e arredores. O Plano de Legado Urbano e Ambiental da cidade do Rio de Janeiro expõe as melhorias concentradas nessas áreas.

A mídia expõe a cidade fundamentalmente através das formações imaginárias, na qual o imaginário elabora o real de modo totalitário (KEHL, 2007). O Rio de Janeiro expressa esse totalitarismo. A Cidade Maravilhosa, sede de mega-eventos, sacia os desejos do capitalismo financeiro-imobiliário da urbanização como negócio e o Estado está pronto com seu aparelho para substanciar o urbano como mercadoria (vide as operações consorciadas nos estádios, na "revitalização" da área portuária, etc.) e a mídia atua, de modo muito eficaz, na transformação desse imaginário em consenso. A Cidade Maravilhosa, as belezas naturais e o discurso da 
cidade moderna, dinâmica, flexível e sustentável servem a quais interesses?, perguntaria um turista desavisado. Esses consensos são na verdade uma expressão da contradição. Oculta-se que a maior parte da cidade e da metrópole carioca sofre cotidianamente com a precariedade e crise do trabalho, com a ausência do tempo livre para a reprodução da vida, para além da reprodutibilidade econômica, com a inexistência ou ineficiência de infra-estrutura: transporte público, saneamento, hospitais, creches, etc. e que essa situação é crítica.

\subsection{Aberturas e fissuras}

A urbanização da sociedade expõe a situação permanentemente crítica que se conforma o modo de produção capitalista: destruição destrutiva, situação permanente de crise estrutural, mundialização do capital, produção de novas raridades e a conformação da impossibilidade do urbano para todos. Acreditamos que as favelas das periferias do extremo oeste realizam essa impossibilidade.

Percebeu-se que há uma racionalidade econômica engendrando um planejamento submetido à mercadoria, que financeiriza o urbano e a pobreza, opacificando a produção do espaço da periferia e se atendo a uma miopia desses espaços. Esther, moradora da favela Paraguai, parece sintetizar tais pontos de vista quando afirma que há uma “'visão de descaso', só lembram da gente na época de eleição. Chegam ai, tampam um buraquinho, um candidato tal abre uma portinha e bota dois médicos ali para fazer aquela tapeação. Todo brasileiro que tem um pouquinho de visão sabe que acabou a eleição aquilo ali vai virar bagunça e até fechar... bota ali um advogado, uma assistente socialzinha. $\mathrm{O}$ olhar deles para gente é assim: um curral eleitoral. Época de eleição, vamos lá tocar nossos bois, dar dentadurazinha. Acabou a eleição, a gente ganhou, deixa eles lá. Daqui a quatro anos a gente enrola eles mais um pouquinho". 


\section{A mercadoria-água e seus segredos}

Neste capítulo buscamos retomar os movimentos anteriores dessa dissertação. No capítulo 1, intitulado Da crise das águas às águas da crise na periferia da metrópole capitalista, desdobramos como a crise ecológica se apresenta como crise da água, sendo essa a aparência da crise estrutural do capital. Traçamos, então, nosso entendimento dos meandros da crise capitalista a partir das águas da crise. Verificamos ainda no referido capítulo como a gestão capitalista da água se apresentava em inúmeras metáforas, particularmente ancorados no debate sobre a produção de novas raridades e como ela ocorre. Destacamos principalmente os processos de privatização do abastecimento de água, como o aparelho de Estado centra suas ações na universalização e não na equidade ocultando uma série de problemas relacionados à distribuição de água (ausência de tratamento, racionamento, intermitência e irregularidade) e de como os movimentos de transformação da água em mercadoria-água (o mercado de água potável) fundamentam um negócio e um comércio bastante lucrativos.

A questão da precariedade do abastecimento de água em favelas na periferia carioca se apresentou como portadora das contradições desse processo. Assim, buscamos compreender como a produção do espaço urbano da Zona Oeste do Rio de Janeiro se realizou, especialmente os movimentos de transformação da urbanização de favelas e de loteamentos na periferia, e como estes se encontram nesse momento de dominância financeira do capital, como urbanização transformada em negócio. Observamos então as ilusões da transparência e a ilusão da opacidade desse processo. Esses debates foram desenvolvidos no capítulo 2, $A$ Ilusão da Transparência e a Ilusão da Opacidade na interpretação da questão social do abastecimento de água.

Esses processos substanciam a situação permanentemente crítica em que se insere marginalmente o proletariado urbano das favelas e periferias da metrópole capitalista. $\mathrm{O}$ aparelho do Estado e as políticas públicas paliativas não solucionam e muito menos resolvem as inúmeras problemáticas que envolvem o saneamento, conforme analisamos no capítulo 3 , A urbanização da sociedade e a mundialização do capital: processos e situações para compreender as favelas da periferia da cidade do Rio de Janeiro e o abastecimento de água como raridade.

Buscaremos observar agora nesse capítulo que se inicia a substância dos fetiches que a mercadoria-água está imersa a fim de retomar tais perspectivas anteriores. Procuramos explicitar como se realizam as mediações da pauta capitalista fetichizada da questão das 
águas, opacificando e ocultando os debates e a crise capitalista da água, com a intenção de demonstrar que mesmo travestido de sustentável, bem comum ou verde, os proprietário de terra e de capital se servem do aparelho do Estado para mediar a monopolização das águas e substanciar sua dominação privada. Nesse sentido, comecemos pela mercadoria-água.

\subsection{O fetichismo da mercadoria-água}

O segredo da mercadoria-água é por assim dizer tautológico: a mercadoria-água é uma mercadoria. Sendo assim, possui o duplo caráter que substancia a mercadoria, valor e valor de uso, e um fetiche que oculta a relação entre produtores, aparecendo como mercadorias autonomizadas. Porta consigo todos os possíveis desdobramentos (concreto-abstratos) que as mercadorias realizam. Porém, seu segredo é ainda mais complexo. Há uma relação profunda entre água e terra e uma renda fundiária abocanhada por proprietários de terra, seja ele privado ou estatal. Existe ainda no Brasil e na sua formação econômico-social sui generis um cativeiro da água realizado pela constituição de 1988 que carrega possíveis desdobramentos do cativeiro da terra desenvolvido por Martins (1986; 2004) quando de suas análises sobre a Lei de Terras, o fim do tráfico de escravos, a instalação do colonato e a produção capitalista de relações não-capitalistas de produção. Desenvolveremos essa relação mais adiante.

A água é uma riqueza natural ${ }^{58}$ tornada mercadoria, apropriada privadamente e produzida como recurso hídrico para ser trocada. Não é um bem natural, um bem escasso (nos termos da escassez pautada pela teoria neoclássica, pela nova economia institucional ${ }^{59}$ ou pela economia ecológica ${ }^{60}$ ) um bem comum ou um serviço ambiental. Sua condição de saciar a

\footnotetext{
${ }^{58}$ Partimos aqui dos termos propostos por Rodrigues (2005) da diferenciação entre riqueza natural, isto é, das múltiplas possibilidades e potências da natureza, em oposição à recurso natural, a natureza tornada mercadoria quando da sua incorporação de trabalho e sua produção deliberada para ser trocada no mercado. Foster (2005) retoma Marx e afirma que a riqueza genuína consistia nos valores de uso, pois esta é uma característica da produção em geral, transcendendo a forma especificamente capitalista. $\mathrm{O}$ autor continua sua argumentação, baseado nas discussões marxianas, afirmando que a contradição entre valor de uso e valor de troca engendrada pelo capitalismo é uma das principais contradições da dialética do capital. Vale retomar uma citação d'O capital: "o trabalho não é a única fonte de riqueza material, isto é, dos valores de uso que ele produz. Como diz William Petty, o trabalho é o pai da riqueza material, a terra é sua mãe" (MARX, 1985).

59 Teixeira (2003) argumenta que a nova economia institucional, vertente do pensamento econômico, particularmente destacada desde a década de 1970, apresenta uma combinação entre a postura metodológica positivista e a temática suscitada pelo historicismo. Esses economistas buscam um escopo teórico que seja, em tese, menos abstrato que a teoria neoclássica colocando as instituições sociais no centro da análise. $\mathrm{O}$ que Teixeira (2003) percebe é que a abordagem que a nova economia institucional faz das instituições se mantém dentro do escopo metodológico da teoria neoclássica, fundamentalmente as noções de abstração, individualismo metodológico e do pressuposto de racionalidade econômica, que levam a um resultado oposto ao almejado: promove-se uma extensão da abordagem neoclássica às demais esferas sociais como a política, a sociologia e a história, levando à uma abordagem economicista e mais abstrata das mesmas.

${ }^{60}$ Para a Economia Ecológica “(...) trata-se de encontrar a escala ótima do macrossistema econômico, permitindo a separação entre (i) crescimento genuinamente econômico (quando os benefícios marginais do aumento da economia superam os custos marginais ambientais do processo) e (ii) crescimento antieconômico (quando, pelo
} 
sede, ou de ser consumida de forma privada ou pública faz parte de sua condição como valor de uso. Porém, como uma mercadoria planejada para ser trocada contém em sua corporeidade líquida o outro do par dialético da mercadoria: ou seja, valor (que aparece como valor de troca). A produção de coisas úteis e de necessidades para a humanidade, como argumenta Marx (1985) reais ou fantasiosas, só se realiza à medida que se mostre lucrativa para o capital. O capitalista produz valores de uso, não por amor, compaixão ou honra, mas somente porque são portadores de valores de troca (TEIXEIRA, 2003; GRESPAN, 2010). Marx (1985) ao descrever o processo de valorização observa que

o valor de uso não é de modo algum, a coisa que se ama por si mesma.
Produz-se aqui valores de uso somente porque e na medida em que sejam
substrato material, portadores de valor de troca. (...) E para nosso capitalista
trata-se das duas coisas. [Que] quer produzir não só um valor de uso, mas
uma mercadoria, não só valor de uso, mas valor e não só valor, mas também
mais valia. (MARX, 1985:155)

Portadora de contradições entre valor de uso e valor, a mercadoria no momento da troca explicita ainda sua encarnação de valor numa outra mercadoria: na forma de equivalente geral. Essa relação encobre que a exteriorização do valor de uma mercadoria se dá na necessidade da expressão de valor em outra mercadoria, percebendo-se nessa relação seu valor de troca. Nesse sentido, há um fetiche que encobre e escamoteia a gênese de sua produção. A mercadoria contém a materialidade de relações sociais e como forma usual, necessária e comum do capitalismo aparece não como abstração, ou como algo do plano ideal que se materializará a posteriori, mas como um abstrato-concreto, fruto da abstração das formas de trabalho que são concretas: dispêndio de cérebro, músculos e nervos da força de trabalho produtora de mercadorias. Materializa-se nesse processo a forma-mercadoria. No caso da mercadoria-água o processo de produção de água potável é fruto do trabalho humano. Há uma economia política da água efetivada pelo aparelho do Estado (via concessionárias municipais ou estaduais) ou por empresas privadas, da seguinte forma: captação, adução (movimento de transporte da água que foi captada até a estação de tratamento), tratamento em seus múltiplos processos e reservação (estocagem da mercadoria-água), sendo estes momentos da produção. Como um momento da distribuição: a rede geral de abastecimento de água (tubulações e encanamentos que transportam a mercadoria-água da estação de tratamento de água para as residências, empresas e industriais). Porém, como uma mercadoria, a água necessita da circulação, ou seja, do movimento da troca de dinheiro por

contrário, os benefícios marginais do aumento da economia se tornam inferiores aos custos marginais). Supõe-se, é claro, que, em algum momento, benefícios e custos marginais se igualem. Tudo isso, no fundo, é a essência do que concebe a economia ecológica". (CAVALCANTI, 2009: 16-17). Foster (2005) observou densamente os equívocos das premissas da Economia Ecológica e também de sua crítica a Marx. 
mercadoria (a realização do pagamento em dinheiro para o recebimento da água). Somente depois desse processo efetiva-se o consumo da mercadoria-água (de um lado do processo como água e do outro como dinheiro).

Contudo, existem momentos em que a abstração não se concretiza. Por exemplo, uma relação de abstração ocorre no momento do pagamento da mercadoria-água para a utilização das suas propriedades físicas, como cozinhar, lavar, beber, plantar, isto é, realizar o seu valor de uso que só ocorre mediante uma relação de troca: dinheiro por mercadoria. Porém o aparecimento do concreto (no caso a mercadoria-água) pode não ocorrer. Explicita-se uma ausência, realiza-se uma abstração: a falta ou intermitência de água. O dinheiro medeia uma relação que pode não se objetivar: paga-se para ter a mercadoria-água e pode-se não a receber, ou não se paga e o abastecimento é cortado.

Paulani (2000), analisando a obra de Marx, discorre sobre o valor que parece provir da natureza das coisas enquanto coisas, não do fato de que elas tenham sido produzidas pelo trabalho humano numa sociedade organizada materialmente pela troca. As mercadorias aparecem no momento da troca como se fossem autônomas, e assim o capital aparece como coisa, não como relação social. Nesse caminho de método proposto por Marx (1985) é possível, ao se partir da mercadoria, chegar ao conceito de "valor" como a relação social de comparação e medida do trabalho contido na mercadoria, e ao fetiche que encobre as ilusões reais no modo de produção capitalista. Essa relação porta consigo a possibilidade da mercadoria ter uma grandeza de valor expressa qualitativamente e quantitativamente na forma-preço. Todavia, Marx (1985) já explicitava que valor e preço passam por um processo de descolamento, podendo ocorrer inclusive processos em que a pura propriedade apesar de não portar valor apresenta preço. A água que sacia a sede quando mercadoria-água é mais uma mercadoria que sacia a sede do capital.

No caso específico da mercadoria-água esse fetichismo aparece de várias formas, ora como gestão ou governança da água, ora como relação poluidor-pagador, ora como desenvolvimento sustentável, sempre e aparentemente comprometidos nos discursos com o planejamento mais eficaz dos recursos hídricos. Quais os significados desse planejamento submetido à técnica e à esses modelos de eficácia? O que quase nunca se apresenta claramente nessas interpretações são suas leituras fundantes: a água como uma mercadoria e a propriedade privada ou estatal da água como lógica e fundamento dos marcos regulatórios e institucionais, utilizando-se inúmeros subterfúgios na realização dessas considerações. Água como valor econômico, conforme referendam inúmeros relatórios do Banco Mundial, constituições dos Estados-nação, agências reguladoras, comitês de bacia, empresas 
transnacionais de mercado da mercadoria-água significam a passagem e a produção da água de riqueza natural para mercadoria com todas as contradições e fetiches. Os fetiches da mercadoria encobrem os processos de produção e circulação da mercadoria-água e "naturalizam" as relações sociais. Dotar a água de um valor econômico, porém, não é uma tarefa simples. O processo de apropriação e transformação da água em "nova" e lucrativa mercadoria exige mudanças nos costumes e nas tradições que as populações mantém com a água, fundamentalmente as relações comunitárias de uso (SHIVA, 2006; GOMES, 2010; CHESNAIS e SERFATI, 2003). Para referendar a criação do mercado e do negócio da água as legislações jurídicas cumprem um papel fundamental, conforme discorre Gomes (2010).

Como já argumentamos, há uma escassez relativa da água em algumas áreas do mundo, assim como a abundância em outros fragmentos do espaço (CLARKE e KING, 2005; BRITTO e CARNEIRO, 2009; REBOUÇAS, 2002; SHIVA, 2006). Não estamos aqui para refutar essa perspectiva ${ }^{61}$. Porém, a escassez relativa é transmitida como um fenômeno absoluto que faz parte da produção discursiva da escassez (SWYNGEDOUWN, 2004). Essa interpretação permite culpabilizar o que se costuma denominar de fatalidades ou catástrofes naturais para justificar a crise estrutural do capital como se fosse "apenas" a crise da água, e em última instância para a especulação sobre a mercadoria-água. Coetâneos a essa crítica, Chesnais e Serfati (2003) argumentam que há uma difusão de idéias e premissas que associam as condições físicas da vida social com alguns "males naturais" a que alguns povos estão sujeitos no processo de desenvolvimento capitalista, e que esses "danos ambientais" são uma infelicidade suplementar no momento de crescimento econômico. Simultaneamente, conforme argumenta Meerganz von Medeazza (2006), as ferramentas discursivas permitem atribuir à escassez relativa a insuficiente capacidade de produção e a carência de recursos financeiros de alguns países, povos e classes sociais. Esses são alguns fundamentos do discurso tecnocrático das soluções à raridade com soluções de engenharia e de gestão política para evitar crises ecológicas. Chesnais e Serfati (2003) chegam a argumentar que "ecologia" e "meio ambiente" carregam consigo um grau elevado de suposta neutralidade diante da realidade, sendo considerados pelos autores termos inadequados e inapropriados se quisermos compreender as relações sociais que se estabelecem no modo de produção capitalista.

\footnotetext{
${ }^{61}$ Martins (2009) expõe que nunca foi tão bem inventariada e documentada a degradação ambiental e a pilhagem dos recursos naturais resultantes da ação das classes sociais e dos países dominantes orientadas para fins especificamente de produção e circulação de mercadorias e acumulação de capital. Chesnais (2009) e Chesnais e Serfati (2003) estabelecem as conexões entre a crise "ecológica" e a crise da civilização humana que explicitam as contradições do capital enquanto tal. Meszáros (2009) analisa que a crise ambiental é mais uma expressão da situação permanentemente crítica do capital e um apontamento da crise estrutural do capital.
} 
A articulação entre a crise estrutural do capitalismo e o avanço da crise das águas (poluição, desperdício, etc.) não é fortuita, não são frutos do acaso. A essência de ambas as crises são as mesmas: a natureza do capital e da produção capitalista, como analisa Chesnais (2009). O dinheiro que se transforma em capital deve crescer para ser reinvestido na produção, isto é, a produção de mercadorias objetiva a produção de lucro realizado na reprodução ampliada. Esse processo precisa constantemente aumentar, em um movimento que não pode ter fim ou limites. Marx já analisava n'O capital que a produção não é mais que a produção para o capital, e observou ainda que o capital representa a forma universal da riqueza (o dinheiro) ${ }^{62}$, apresentando uma tendência incessante e ilimitada de produzir seu próprio limite.

Para crescer, o capital deve produzir e apropriar-se do valor criado pelo trabalho humano e da mais valia gerada. Esse processo significa, inclusive, a apropriação do solo e subsolo indefinidamente, como tem feito desde que foi fundado como um modo de produção que abrange formações econômico-sociais particulares e, de fato, quando começou sua expansão global.

As crise(s) ecológica(s) planetária(s), cujos efeitos se repartem de forma muito desigual, são os produtos do capitalismo, mas nem por isso são fatores centrais de crise para o capitalismo (CHESNAIS e SERFATI, 2003).

Hoje, a "crise ambiental" se desenvolve de modo acelerado sob o efeito da busca pelo capital de "soluções" (CHESNAIS, 2009). Fontenelle (2010) argumenta sobre a ideologia do consumo responsável pelo meio ambiente como uma nova produção discursiva da cultura de consumo. Essa é uma das formas que o modo de produção capitalista encontrou para transformar a "redenção" em mercadoria. Porém, essas construções discursivas que se materializam em práticas neoliberais, “ongueiras” ou de políticas públicas, não fazem mais que escamotear as contradições profundas (superacumulação endêmica, autonomização da acumulação financeira, renda diferencial, sobrelucro etc.) tornadas possíveis pela liberalização, desregulamentação e globalização econômica, num processo mundializado de financeirização, inclusive da natureza e das relações com a natureza. Tomada por este ângulo, a crise ecológica planetária (no qual a crise da água está inserida) é, pois, uma "crise capitalista”. Fundamental observar que a mercadoria-água imersa nessa crise irá apresentar inúmeros fetichismos que ocultam sua essência. A forma social se autonomiza da forma valor de uso, isto é, das propriedades físicas da água. A existência social absorve a existência

\footnotetext{
${ }^{62}$ Teixeira (2007) ressalta que as mercadorias não se tornam comensuráveis pela existência de dinheiro, é o dinheiro que tem sua existência logicamente derivada a partir de uma sociedade de produtores de mercadorias.
} 
natural da água descolando seu sentido de utilidade, sendo posto na lógica da produção para valorização ${ }^{63}$.

\subsection{O fetiche do Estado e do princípio poluidor(usuário)-pagador}

A mercadoria-água tem um fundamento: tornada raridade no discurso e na prática a partir da sua produção (baseada na criação de valor de uso social), é objeto de valorização. Porém, se estabelece uma contradição: a água é uma condição necessária à reprodução da vida e imprescindível à reprodução econômica, e sua condição de utilidade é anterior à sua necessidade. A mercadoria-água, porém, tem uma gênese pregressa à sua condição de mercadoria. Para se tornar mercadoria, ela se tornou antes propriedade privada ou estatal, e como parte da propriedade do proprietário de terras a água era renda fundiária (como ainda é). Porém, quando se produz água potável ou água de reuso incorpora-se trabalho à água tornando-a, portanto mercadoria. Esse movimento exige a interpretação de algumas relações fetichistas, partindo-se da mercadoria, mas não se limitando a ela para não estabelecermos um movimento mecanicista desse processo. Como uma mercadoria, a água se torna mais uma mercadoria na coleção monstruosa de mercadorias do mundo moderno, conforme argumenta Marx logo no início d'O Capital. Oliveira (2010) argumenta que o modo capitalista de produção não se restringe à produção, mas também não se resume à circulação de mercadorias, sendo que o processo se faz dialeticamente articulado. Constrói-se e reconstróise um movimento de reprodução ampliada do capital que fundamenta a produção voltada à

\footnotetext{
${ }^{63}$ Os programas de urbanização de favelas cumprem um papel decisivo no processo de fundamentar a realização da vida via troca de serviços por pagamentos em dinheiro. A urbanização é um negócio lucrativo para o Estado e para as empreiteiras. Os termos do Programa Favela Bairro demonstram esse movimento metaforicamente, aparecendo sempre como "regularização", "ordenamento", transformação do "informal" em "formal". Não esqueçamos que as empresas privadas, os bancos e o aparelho do Estado estão absolutamente amalgamados. Por exemplo, o BID financiou a Prefeitura do Rio de Janeiro nos dois momentos do Programa Favela Bairro 1 e 2, e a Prefeitura terceirizou boa parte do Programa às empreiteiras. Como já analisamos o BID influenciou fortemente o rumo das políticas de urbanização de favelas, e no caso do Favela Bairro essa prática se renovou. Arantes (2006) argumenta que a doutrina da "recuperação plena de custos" (full cost recovery) passou a nortear as políticas urbanas dentro de um modelo "auto-sustentável", baseado em receitas tarifárias não-subsidiadas. Os habitantes das favelas que não pagavam por serviços e infra-estrutura sofriam os processos de urbanização, apresentados inicialmente como marketing social: "A água está chegando na favela". Porém, se oculta, "como os moradores irão pagar por isso tudo?". Para se recuperar plenamente os custos os moradores terão que pagar por todos os serviços. Arantes (2006) analisou também como os serviços prestados na periferia do capitalismo eram de pior qualidade, o padrão da construção da habitação era estabelecido de acordo com a renda do trabalhador, dentre outros parâmetros. Nas favelas das Três Pontes e Divinéia observamos as constatações desses problemas em entrevistas e observações em campo: obras que não aconteceram, infra-estruturas inconclusas, material utilizado de padrão mais baixo, etc. Arantes (2006) argumenta ainda que o ônus da escolha por serviços piores e mais baratos foi transferido ao usuário (que passa a "autofocalizar" de acordo com sua capacidade de pagamento) até o limite de não ter serviço algum, caso não tenha como pagar. O Favela Bairro realiza essas características é ao mesmo tempo uma política pública "de mercado" e a explicitação da transposição da lógica das empresas (e do capital financeiro bancário) para a "gestão" e o planejamento estratégico das cidades. Sara, moradora da favela das Três Pontes, nos parece sintetizar essa questão: "Viver está muito caro!".
} 
troca, a troca de mercadorias por dinheiro e de dinheiro por mercadorias, num movimento incessante e expansivo, buscando a medida da desmedida. Isso decorre do pressuposto apresentado por Oliveira (2010) de que o modo capitalista de produção não é na essência um modo de produção de mercadorias no seu sentido restrito, mas sim modo de produção de mais-valia. Além disso, deve-se observar que o produto final do processo de produção não é a mais-valia e sim a mercadoria com trabalho vivo e trabalho morto reavivado pela força de trabalho encarnado de mais-valia, pois o que do lado do capitalista aparece como valorização do capital da parte do trabalhador é dispêndio de excedente de força de trabalho (MARX, 1985). "O capital é trabalho morto, que apenas se reanima, à maneira dos vampiros, chupando trabalho vivo e que vive tanto mais quanto mais trabalho vivo chupa". (MARX, 1985). A água, por exemplo, é a matéria-prima tornada capital constante, produzida para realizar-se na troca como a mercadoria-água, e que pode inclusive apresentar inúmeros predicados: água potável, água de reuso, água para a produção do agronegócio, água para a produção industrial, dentre outros. Nesse sentido, perda de água ou desperdício significa mercadoria perdida e não aquela que poderia saciar a sede. Nesses termos, a tessitura que liga a água à humanização do homem se perde.

Altvater (2007) argumenta que nas interpretações clássicas e, sobremaneira, nas neoclássicas da relação homem-natureza, há uma racionalidade individual engendrando relações sociais. O fio condutor dos discursos e das práticas é a consideração das riquezas naturais como recursos naturais escassos. Esse é o cerne dos debates, o contrário do que ocorre com o pensamento malthusiano, no qual o excesso de demanda é a categoria decisiva. $\mathrm{Na}$ teoria neoclássica, a categoria de escassez aparece como a peça central do raciocínio econômico. Lima (2008) ao analisar a economia neoclássica expõe que esta apresenta a escassez relativa como uma questão que deve ser administrada pelo sistema de mercado, pois nele os preços refletiriam corretamente, de maneira "adequada" e racional, a referida escassez relativa dos bens e serviços em circulação. Essa então seria não só a melhor, mas a mais eficaz maneira de resolução dos problemas. Os economistas neoclássicos centralizam seus esforços na chamada "alocação eficiente de recursos escassos", com a finalidade de presentes e futuros alternativos através do sistema de preços de mercado, como desenvolve criticamente Lima (2008). O autor disserta que partindo-se dessa perspectiva, não é surpresa que para os adeptos do arcabouço neoclássico as questões sociais e as contradições ambientais imbricadas sejam resolvidas pelo mercado, o que seria o "adequado" na redução e mesmo resolução da problemática da "sustentabilidade do desenvolvimento". Em última instância, trata-se "apenas" de administrar eficientemente essa outra dimensão da escassez mais geral. Essa 
argumentação neoclássica demonstra o sentido tautológico do processo: o capitalismo realiza a pilhagem natural e se apresenta como a melhor solução para a "resolução" dos problemas.

Consideramos possível estabelecer aqui a relação de instrumentos reguladores utilizados pelo Estado para reafirmação desse fetiche que incide sobre a mercadoria-água, qual seja, o princípio poluidor-pagador ampliado para usuário-pagador. Este princípio é inspirado em análises do início do século XX de Artur Cecil Pigou. Em 1920, esse economista inglês sugeriu o estabelecimento de taxas e impostos para neutralizar os danos dos custos externos (ou externalidades), entre eles os danos ambientais de variadas origens, estabelecendo o que os economistas neoclássicos convencionaram denominar de princípio do poluidor-pagador (SILVEIRA, 2006). Esse "princípio" trata justamente de corrigir as “externalidades negativas" mediante cobrança de uma taxa ou tributos (TORRES e VIANA, 2007). Exemplo dessa perspectiva se apresenta nas premissas de Mankiw (2005):

[Para os] Economistas as boas políticas ambientais começam com o reconhecimento do primeiro dos Dez Princípios de Economia (...) É claro que o ar puro e a água limpa são valiosos. Mas seu valor precisa ser comparado ao seu custo de oportunidade - ou seja, aquilo que as pessoas precisam abrir mão para obtê-los. É impossível eliminar completamente a poluição (...) alguns ativistas ambientais prejudicam sua própria causa recusando-se a pensar em termos econômicos. Um meio ambiente limpo é um bem como qualquer outro. (...) Além disso, como a maioria dos outros bens, ar puro e água limpa estão sujeitos à lei da oferta e da demanda. (MANKIW, 2005: 215).

Pereira (1996) afirma que a cobrança pelo uso da água é uma “forma de racionalizar a utilização desses recursos", como condição suplementar de satisfazer aos usuários competidores, garantindo uma maior eficiência produtiva, o que seria um elemento essencial para o desenvolvimento econômico integrado das bacias hidrográficas. O autor se vale de variáveis e de justificativas que vão da lógica econômica e financeira, passando pela distribuição de renda e chegando até a "equidade social" (contribuição pela utilização de recurso ambiental para fins econômicos) que a cobrança trará. O debate puramente econômico (e por que não dizer econométrico?) descolado do sentido da Economia Política e de sua crítica explica a realidade através de modelos e modelagens.

Em tese, o princípio poluidor-pagador, através do sistema de preços, induziria os consumidores a reduzir seu consumo excessivo por gratuidade, ou sua ação poluidora para evitar a cobrança (TORRES e VIANA, 2007). Altvater (2007) rebate veementemente esse fetiche sobre os recursos naturais, pois para o referido autor existem regras sobre como lidar com a escassez, que são concebidas como um remédio para evitar excessos de demanda 
(ALTVATER, 1993). Hoje, a aplicação de regras "racionais"64 de decisão, como apontado pela teoria neoclássica, sob condições de raridade como forma de sustentabilidade de uma situação de real excesso de demanda é altamente duvidosa. O Estado tem um papel nessa equação, sendo um importante regulador e administrador das crises capitalistas, gerenciando interesses e substanciando tendencialmente decisões: regula o "irregulável", administra o “inadministrável”, iguala os desiguais. O princípio poluidor-pagador e as cobranças pelo uso da água necessitam do aporte político e jurídico do Estado. Sendo assim, desdobrar a interpretação sobre o Estado e seu fetiche é fundamental.

Marx aponta que a desigualdade fundamental está na distribuição dos meios de produção: enquanto todos são proprietários da força de trabalho, apenas alguns poucos são proprietários dos meios de produção. E essa é uma desigualdade fundamental porque é absolutamente necessária para fazer funcionar o sistema econômico - um mundo em que todos fossem donos dos meios de produção não teria lugar para o mercado capitalista, para o lucro e o sobrelucro. Fazendo-se a distinção entre os tipos de propriedade (meios de vida ou meios de produção), então se percebe que o real não está para a esfera das leis, como considerava Hegel ${ }^{65}$.

Estão dados aqui os fundamentos para Marx afirmar que o Estado não é o Estado de todos, mas sim de uma minoria: a minoria dos proprietários dos meios de produção. Para Marx o Estado é classista, se organiza no sentido da defesa dos interesses da classe dominante. E é importante esclarecer que a noção de classe em Marx está baseada naquela desigualdade fundamental: há uma oposição clara entre o dono dos meios de produção e o dono (vendedor) da sua força de trabalho. Essa divisão de classe está para além da noção de classe hegeliana, mais ligada à categorias de trabalho.

Marx irá afirmar que, no Estado classista, as leis não fazem o papel de simplesmente arbitrar sobre os diferentes interesses privados, mas que elas realizam o papel de fazer a manutenção da ordem vigente. Assim, nunca se dissolve a clivagem entre trabalhador e proprietário dos meios de produção. A lei, o direito e a ordem jurídica cumprem um papel de

\footnotetext{
${ }^{64}$ Tudo que fica fora dos sentidos estritamente fundamentados da economia capitalista é considerado "irracional". A razão capitalista fundamenta-se na desmedida do lucro, na valorização do valor, na sociedade de consumo, no fetichismo da mercadoria, do dinheiro e do capital e essas são suas bases "racionais". Destacamos que as palavras não são elencadas num sentido aleatório, mas apresentam um sentido socialmente explicito de hierarquização social.

${ }^{65}$ Salviatti (2010) argumenta que para Kant, o ser era capaz não de absorver os objetos em si, mas apenas fenômenos destes. Hegel reabilita o ser (retomando uma questão kantiana, porém com outro elucidar) no qual o conceito corresponde à realidade, formulando uma dialética idealista, ou seja, a idéia tinha sua imposição na realidade e a verdade significa que o conceito corresponde à realidade. A transformação dialética de Marx reabilita o real em relação à idéia, tornando a dialética referenciada à materialidade e não ao pensamento, o real submete pois os conceitos à verdade ou ao erro, e não ao contrário.
} 
não desfazer essa clivagem, apenas amortecem, anestesiam, postergam, jogam para frente, suspendem ou realocam os conflitos, para que essa divisão continue existindo. Assim, todo ganho que se dá ao trabalhador visa fazer com que continuem existindo trabalhadores.

Embora a análise marxista revele o Estado moderno como Estado classista, ele aparece como Estado de todos na esfera das leis. Essa ênfase na aparência Marx já descortinava no Prefácio da Crítica da Economia Política

Minhas investigações me conduziram ao seguinte resultado: as relações jurídicas bem como as formas do Estado, não podem ser explicadas por si mesmas, nem pela chamada evolução geral do espírito humano; estas relações têm, ao contrário, suas raízes nas condições materiais de existência, em seu conjunto, condições estas que Hegel, a exemplo dos ingleses e dos franceses do século XVIII, compreendia sob o nome de "sociedade civil". (MARX, 1984: 231).

Engels ([1884], 1995), amplamente influenciado pelos pressupostos marxianos, afirma que "a força de coesão da sociedade civilizada é o Estado, que, em todos os períodos típicos, é exclusivamente o Estado da classe dominante e, de qualquer modo, essencialmente uma máquina destinada a reprimir a classe oprimida e explorada".

Marx desenvolve o conceito de ideologia para referir-se ao mecanismo de descolamento entre as idéias e o real, que faz com que a realidade seja vista pelo avesso, promovendo a ilusão. A ideologia aliena as idéias dos dominantes dos próprios dominantes, como se fosse uma reivindicação universal - fazendo aparecer o Estado classista como Estado de todos. A ideologia é socialmente necessária no sentido de que ela propicia a reprodução da sociedade que está posta, mas de forma a mascarar a contradição que existe na prática. Enquanto Hegel via nas leis e no Estado uma relação ideal com a prática social, para Marx eles são mais uma ilusão, são instrumentos da classe dominante para a perpetuação e o mascaramento de sua dominação. Estado e sociedade civil são então extremos reais, que "não podem ser mediados um pelo outro, precisamente porque são extremos reais". Não há entre eles relação reflexiva, pois são extremos que "não tem nada em comum entre si, não demandam, um ao outro, não se complementam" (MARX, 2005).

Para Marx, então, o Estado político, figurado na Constituição, representa a separação da sociedade em relação à sua própria essência, sua vontade genérica. A sociedade é o Estado real, a base da constituição. Ela é o todo, o poder constituinte; a constituição é a parte, poder constituído (POGRENBINSCHI, 2009). A alienação política se estrutura no momento em que a sociedade é desconectada daquilo que deveria ser a apresentação de sua realização política. Realiza-se a inversão e a alienação política se substancia; a sociedade civil, ou seja, o "Estado real" é privado do conteúdo estatal, substanciando a separação e oposição entre Estado e 
sociedade civil, Estado político e não político. As frações de classe capitalista irão aparelhar o Estado na objetivação de seus interesses. Insere-se a essa contradição o fato da impossibilidade da mediação entre esses dois pólos opostos articulados com e pela modernidade política, em que a Constituição é uma das expressões que explicita essas contradições.

Somente o desvanecimento do Estado e da sociedade civil é o caminho para a sua resolução, sendo a crítica à modernidade política e suas materializações e dinâmicas classistas uma profunda objeção aos caminhos tomados pelo Estado no seu contundente papel na acumulação de capital pelas classes e frações de classes dominantes.

O Estado se revelaria de forma incompleta, incapaz de constituir-se como um todo. A relação Estado-sociedade passa a ser expressa pelos antagonismos nas dimensões das contradições entre o Estado político e não político (POGREBINSCHI, 2009). A "verdadeira democracia” não se realiza, esta só pode se realizar em uma sociedade onde não haja mediações para a manutenção da alienação política e econômica. Realiza-se mediante a criação de outro lugar para a Política: uma comunidade real de associação de homens livres e iguais, no qual não há sentido conceber o social e o político como instâncias fraturadas. $\mathrm{O}$ problema se cimenta no momento dessa fratura entre o econômico, o social e o político.

A atomização e autonomização em que a sociedade civil é mergulhada expõe que os aspectos da vida social, em suas estruturas e também em suas minúcias, são eclipsadas pela acumulação do capital: são alienados (e separados a fórceps) na produção, distribuição, circulação e consumo, nos processos cotidianos de valorização do valor, assegurado pelo Estado, garantidor em última instância do conjunto do processo de reprodução ampliada. $\mathrm{O}$ Estado político é uma abstração da sociedade civil (MARX, [1843], 2005).

Tudo que é sólido e estável se desmancha no ar, tudo que era sagrado é profanado e os homens são obrigados finalmente a encarar sem ilusões sua posição social e as suas relações com outros homens (MARX, [1848] 1998 p. 43).

No Prefácio à edição alemã do Manifesto Comunista, Marx e Engels ([1848] 1998:72) afirmam que a Comuna de Paris foi o primeiro momento no qual o proletariado atingiu o poder político, mas "a Comuna de Paris demonstrou, especialmente, que não basta que a classe trabalhadora se apodere da máquina estatal para fazê-la servir a seus próprios fins". O Estado está corroído, ele porta as contradições, porém não é através dele que as contradições serão desvanecidas e somente são reformadas.

Marx vincula a formação do Estado capitalista à evolução histórica da propriedade privada. Ao passo que a institucionalização da propriedade corresponde à um determinado 
modo de produção e à uma determinada divisão do trabalho, o Estado apresenta-se como uma forma política a fim de servir-lhes de proteção e garantia (POGREBINSCHI, 2009). A manutenção e a reafirmação da propriedade privada são movimentos inclusive para a manutenção tautológica de sua existência. Nesse sentido, parecem que estão coadunadas as premissas da propriedade privada em relação as águas. Essa relação pode ser explicitada no interesse atual em mecanismos como "governança da água" e a cobrança pelo uso da água. $\mathrm{O}$ Estado irá, então, garantir primordialmente aos capitalistas e proprietários de terra e água a outorga do uso da água.

O “instrumento legal da outorga de água" é a chave do acesso à água na atual legislação brasileira de recursos hídricos (REVERS e MALVEZZI, 2009), no Plano Nacional de Recursos Hídricos (PNRH). Este é um instrumento jurídico através do qual o Estado brasileiro concede a exploração privada de um bem da União, no caso, a água. Revers e Malvezzi (2009) argumentam que há inúmeros casos no Brasil em que o Estado garantiu a utilização de grandes volumes de água a interesses explicitamente privados (as frações de classe proprietárias de capital e proprietárias de terra), como no oeste da Bahia em que grandes latifundiários desviaram rios para o interior de suas propriedades. O caso de Manaus na privatização dos serviços de água e esgoto é outro exemplo das inúmeras contradições de tais processos, o BNDES financiou metade do valor da privatização, entregue a empresa Suez. O dinheiro investido foi recuperado em 14 meses devido ao aumento expressivo das tarifas e pago pela população (OLIVEIRA, 2007). No estado do Paraná, Gomes (2010) analisou o dispositivo da Lei $\mathrm{n}^{\circ}$ 9.437/ 97 e constatou que as produções agrícolas e pecuárias estão isentas da cobrança pelo uso da água (beneficiando principalmente o agronegócio paranaense).

O Estado irá também criminalizar formas de apropriação coletiva da água como a lei da vedação de construção de poços artesianos no estado do Rio de Janeiro. E manter mais de 30 milhões de pessoas sem abastecimento de água. Demonstração desse processo é a questão da precariedade do serviço de abastecimento de água prestado pela CEDAE nas favelas e periferias da cidade do Rio de Janeiro. A política incisiva de "ordem pública” do aparelho de Estado carioca (com a criação inclusive de uma Secretaria de Ordem Pública) se apresenta, por exemplo, na política de perseguição e criminalização das ligações clandestinas de água implementada pela CEDAE, conforme analisamos nos trabalhos de campo dessa pesquisa.

A questão sobre a dominação privada do direito de outorga chega a níveis inacreditáveis. Está em implantação por algumas companhias de saneamento no Brasil o sistema pré-pago de abastecimento de água, por exemplo, no Tocantins pela Companhia de 
Saneamento do Tocantins (SANEATINS) e em Arraial do Cabo no Rio de Janeiro pela Prolagos (companhia privada de água e esgoto ${ }^{66}$. Todas essas ações buscam evitar a inadimplência, aumentar o número de consumidores de água e diminuir o número de ligações clandestinas. Mas, o sistema pré-pago é vangloriado pelo Banco Mundial como alternativa para reduzir o número de pessoas sem abastecimento de água. Este sistema consiste na substituição dos hidrômetros por um equipamento composto de uma turbina acoplada a uma central eletrônica e um medidor eletrônico de consumo, que poderá fazer, via telefone, a transmissão dos dados para a companhia de abastecimento. O "cliente" (na terminologia das empresas de saneamento) compra créditos de água, e quando estes terminam o abastecimento é imediatamente sustado. O que acontece na prática, como observado por Silva (2010) e Echevenguá (2004), é que se institucionaliza a ausência de água e se referenda que a mercadoria-água é mais uma mercadoria, sendo a mediação para o recebimento de água o pagamento em dinheiro. No caso de Arraial do Cabo no Rio de Janeiro o sistema pré-pago é realizado especialmente em favelas.

A partir do instrumento jurídico da outorga de água se consolida a cobrança pelo uso da água. São fundamentais para tal estabelecimento dois requisitos: a outorga (mediação/ocultamento da propriedade) e a "utilização" (mediação/ocultamento do dinheiro) da água (HENKES, 2003). Deste modo, todos os usos passíveis e possíveis de outorga são consequientemente passíveis e possíveis de cobrança. A cobrança é realizada pelas agências de água que são os órgãos executivos das bacias hidrográficas (HENKES, 2003), unidade de planejamento e gestão alçada a um protagonismo. Consideramos esse processo mais uma explicitação de que as questões políticas, econômicas e sociais estão submetidas a um revestimento de naturais. Os comitês de bacias hidrográficas são elevados a um papel de mediação de conflitos (entre os proprietários de terra e os proprietários de capital, entre os próprios capitalistas e entre os próprios proprietários de terra, e como muitas vezes fundidos nas mesmas figuras entre estes e os trabalhadores e camponeses) e a "descentralização" que o Estado realiza não é sintoma de "fraqueza", mas sim um reforço do papel de salvaguardar econômica e financeiramente os interesses privados. Observemos a análise do Banco Mundial (2003):

A descentralização é um dos valores básicos da política nacional de recursos hídricos. Embora a atenção esteja agora voltada para o papel dos comitês de

\footnotetext{
${ }^{66}$ A Prolagos Concessionaria de Serviços de Água e Esgoto administra cinco municípios da Região dos Lagos no estado do Rio de Janeiro (Arraial do Cabo, Cabo Frio, Búzios, Iguaba Grande e São Pedro da Aldeia, desde 1998). A Prolagos é controlada pelas Águas de Portugal, uma empresa pública de direito privado (empresa de economia mista), segundo Vargas e Lima (2004). A Águas de Portugal se encontra no pacote de privatizações do novo governo português que assumiu em 2011.
} 
bacias hidrográficas, encarregados de definir prioridades e conciliar interesses conflitantes, deve-se ter em mente que estes não poderão funcionar de maneira apropriada se não contarem com substancial apoio técnico e financeiro. Atualmente, a evolução da gestão das bacias hidrográficas está presa a um círculo vicioso. Os novos organismos devem demonstrar sua competência para conseguir apoio e estabelecer sua credibilidade. Para tanto, eles necessitam de recursos humanos e financeiros para poder realizar um bom trabalho técnico e custear novos investimentos. De modo a financiar suas atividades, porém, é preciso que cobrem dos usuários da água, medida que só será aceita uma vez que tenham logrado comprovar sua competência. (BANCO MUNDIAL, 2003:13, grifos nossos)

A cobrança pelo uso da água também é um instrumento da PNRH, que é definida como um

preço público, ou seja, não é tarifa, imposto ou taxa. A cobrança constitui-se como uma retribuição que o usuário faz à sociedade por utilizar privativamente um bem que é de uso comum Atualmente, são pagos os serviços de tratamento e captação da água e não pela utilização do bem ambiental, água. Segundo o artigo 19 da PNRH, a cobrança objetiva: Ireconhecer a água como um bem econômico e dar ao usuário uma indicação de seu real valor; II- incentivar a racionalização do uso da água; III- obter recursos financeiros para o financiamento dos programas e intervenções contemplados nos planos de recursos hídricos. (HENKES, 2003: 20).

Ressalva-se que consideramos problemática a associação muitas vezes direta entre público e estatal. Compreendemos que não é tornando na lógica do Estado capitalista um bem em público (ou melhor, estatal) que se garante a equidade no seu acesso. Esse movimento torna a água um serviço ambiental realizado por intermédio do Estado, incorporando as pautas dos organismos internacionais e das empresas transnacionais. Já analisamos que a universalização dos serviços de infra-estrutura e serviço está longe de ser atingida, assim como está distante a equidade na distribuição de água. Mesmo garantido que todos tenham água isso não garante que a equidade se realize. Afinal, numa sociedade em que todos tivessem tudo, não haveria possibilidade de monopolização e garantia da dominação privada.

\subsection{O fetiche do serviço ambiental (e seu mercado "ambiental")}

Nossa análise buscou ainda compreender a caracterização da água como serviço ambiental (ou seja, a compreensão de outros porquês do tratamento da água como um bem mercantilizável). Auxiliados por Veiga Neto (2008), analisamos aquelas características que conduzem uma determinada riqueza natural, bem ou serviço a ser transacionado no mercado. O autor fundamenta sua discussão na classificação de bens escassos da teoria econômica neoclássica. 
A primeira característica que Veiga Neto (2008) expõe diz respeito à exclusividade de oferta de serviço e mercado. Um determinado bem, para o autor, é chamado de exclusivo quando só pode pertencer a um determinado agente social e econômico, no qual somente ele possa usar este bem e prevenir que outros também o usem. É um termo vinculado com a definição dos direitos de propriedade, privados ou não, e tem íntima relação com as forças de mercado. Os agentes econômicos do mercado de capitais "ecossistêmicos" ou "naturais" afirmam que se o bem não for exclusivo, não pode ser transacionado de forma eficiente no mercado e a razão para tais afirmações de tais agentes é de que não há o incentivo à sua produção se ele pode ser utilizado por qualquer um sem que este pague por seu uso; por outro lado, aquele que usa sem que seja necessário pagar por isto não encontra qualquer incentivo para fazer este pagamento. Nesse intento, a fixação do monopólio sobre os "bens naturais" e sobre o "território" seria não só eficaz, como justa e necessária. As soluções dos problemas são tautológicas, não respondem a nenhum dos problemas estruturais e apenas postergam as questões (a saída e o pensamento único são o mercado).

A segunda característica fundamental de um bem para ser transacionado no mercado é o seu caráter de rivalidade, ou seja, o uso de uma unidade de um determinado bem por um agente econômico impede o uso desta mesma unidade por outro agente ao mesmo tempo (VEIGA NETO, 2008).

Um bem ou serviço é considerado não rival quando seu uso por um agente tem um impacto insignificante na quantidade ou na qualidade deste mesmo bem ou serviço disponível para outro agente econômico (CLARK e KING, 2006). Segundo a análise de Veiga Neto (2008), alguns dos principais serviços ambientais estão nesta categoria, tais como a camada de ozônio e a estabilidade climática, onde, por exemplo, a proteção oferecida pela primeira à um cidadão em relação à filtragem dos raios ultravioleta que atingem a Terra em nada diminui a proteção oferecida a quaisquer outros cidadãos.

Uma terceira característica seria um refinamento na noção de bens rivais, que seriam bens congestionáveis, ou seja, aqueles bens e serviços que se usados por um número pequeno de atores tem características de não rivais, mas que quando usados de forma intensiva caem de qualidade e passam a ser considerados bens congestionáveis e, portanto, passariam a ser rivais. Neste caso, pode-se observar boa parte dos chamados serviços ambientais ligados à água, como pondera Veiga Neto (2008:18).

Este processo de transição da água, em diversas partes do mundo, de um bem "não rival" (segundo terminologia da denominada Economia Ecológica) para um bem cada vez mais congestionável, certamente é um dos fatores que torna a água e os serviços decorrentes 
da mesma cada vez mais suscetíveis de serem incorporados em um mercado de serviços ambientais (VEIGA NETO, 2008) eminentemente capitalistas, trazendo para esse mercado as contradições existentes de toda a história do capitalismo, de criação de novas propriedades e de novos mercados.

Apresentado o debate que se situa no que vem sendo chamado de Economia Ecológica (demasiado apoiada nas discussões de autores de aporte neoclássico, apesar de suas veementes negativas), gostaríamos de expor nosso distanciamento teórico e político de tais interpretações. Temos como premissa um ponto de vista materialista histórico e propomos aqui um aprofundamento crítico a tais argumentações. A terra, incluindo as riquezas naturais em geral, antes de ser convertida em propriedade privada é um recurso coletivo, comum, comunitário ou estatal. Quaini (2002), retomando Marx, argumenta que as relações capitalistas de produção somente podem nascer e reproduzir-se quando no mercado se encontram o produtor transformado em trabalhador livre (proprietário da força de trabalho) previamente alienado da propriedade das condições objetivas da realização do trabalho, e o capital como proprietário destas condições e meios de trabalho. Nesse processo de expulsão de populações camponesas, indígenas, quilombolas ou mesmo as populações atingidas pelas construções de barragens sujeita-se a terra e as riquezas à ela imbricadas ao capital, não sem resistências.

Gomes (2010) afirma que as leis sobre as águas no Brasil não foram resultado exclusivo da evolução da racionalidade jurídica, como pregam diferentes teóricos (HENKES, 2003; REBOUÇAS, 2003; VEIGA NETO, 2008), passando a incorporar preocupações com a “preservação dos recursos naturais do planeta". Para além dessa perspectiva fetichista, há uma disputa pela transformação da água como mercadoria envolvendo bilhões de dólares na qual empresas transnacionais como a companhia GDF Suez (Suez-Lyonnaise des Eaux) e a Veolia (antiga Vivendi), o Estado francês (no qual o abastecimento de água é dominado por empresas privadas desde o século XIX) e o Banco Mundial são argutos protagonistas. Essas empresas e muitas outras interessadas no mercado de águas são responsáveis pela fundação do Conselho Mundial da Água (WWC) e a Parceria Global da Água $(\mathrm{GWP})^{67}$ que zelam pelas suas posições privilegiadas no crescente mercado mundial da água por meio de iniciativas como a Declaração de Dublin.

\footnotetext{
${ }^{67}$ Esses organismos são conhecidos também como aglutinadores dos grandes monopólios de águas envasadas e companhias transnacionais interessadas nos serviços de água e esgoto, e os serviços ambientais relacionados à água e as grandes corporações bancárias e financeiras. Petrella (2002) chama esses capitalistas de senhores da água.
} 
A água, quando não instituídos os direitos sobre a propriedade da terra e dos recursos hídricos (passagem da água para mercadoria-água), é uma riqueza natural ou uma propriedade coletiva, isto é, as populações utilizam a água não para a reprodução capitalista, mas para a reprodução da vida. A única forma de garantir o ganho do capitalista é por meio do direito de propriedade com o monopólio. Particularmente na questão da água, assim como a terra, um monopólio social e natural através de novos cercamentos, conforme argumentaremos posteriormente. Pois, tal como a terra, quer a água seja cedida como meio de produção, quer o seja como bem de consumo para uso privado, seu proprietário recebe uma renda.

Outra argumentação é de que a água sofre um processo contínuo de congestionamento, como apresentado por Veiga Neto (2008), devido à demanda crescente para os mais diversos fins aliados à intenso desperdício. Os índices de desperdício de água realmente são altíssimos no Brasil e a demanda por água também tem aumentado particularmente desde a década de 1950. Nossa argumentação, porém, não segue o caminho do fetiche dos serviços ambientais, mas deve se assentar nas questões acerca das classes sociais que disputam a utilização e propriedade da água no Brasil: proprietários de força de trabalho, proprietários de capital e proprietários de terra. O agronegócio apresenta altos índices de desperdício de água com a utilização da irrigação, e em muitos estados recebe isenção dos custos dessa matéria-prima. Para o capitalismo industrial e seus altos índices de poluição industrial, são depositados resíduos da produção nos rios e lençóis freáticos evitando os custos de produção com a limpeza. De outro lado ainda há mais de 80 milhões de brasileiros com ausência de esgotamento sanitário e mais de 30 milhões sem abastecimento de água, segundo dados do Ministério das Cidades. Concordamos com Ioris (2004) que a cobrança pelo uso da água é uma solução mistificadora que responde a um falso problema, ou seja, a geração de recursos para manter um modelo autoritário e excludente de desenvolvimento econômico em que a água é tratada como matéria prima, capital constante e custos de produção. Ioris (2004) argumenta ainda que a cobrança pela captação de água e lançamento de efluentes reforça a "commodificação" (transformação de tudo em commodities) da natureza e aprofunda a inserção da água nos processos de produção e circulação de capital. Há então uma questão de classes sociais nesse processo, que não pode ser negligenciada.

A criação de raridades e de serviços/produtos ambientais são marcas do processo de globalização da economia de mercado, e em nossa compreensão são também um dos ápices do discurso de dominação capitalista (a naturalização das questões sociais e o consenso de classes). 


\subsection{O fetiche do desenvolvimento sustentável e do bem comum}

Incorporar a palavra "sustentável" a "desenvolvimento" foi um ajuste na terminologia, mantendo-se o modo de produção capitalista e atribuindo à série de pilhagens naturais e suas consequentes questões aos desvios do "modelo" de cada país e não as questões intrínsecas ao modo de produção (RODRIGUES, 2005). Compreendemos que o processo deve ser analisado numa relação fetichista entre ocultamento-descolamento-deslocamento para se explicitar a passagem da riqueza natural para a mercadoria. Explicamo-nos. $\mathrm{O}$ ocultamento da forma mercadoria produz o fetiche intrínseco ao processo de produção de mercadoria, oculta-se essa relação de modo a não aparecer o processo de monopolização, isto é, a instituição da propriedade privada das riquezas naturais particularmente expropriando e combatendo os usos coletivos da água, do ar e por extensão de toda natureza. Damiani (1984) argumenta que o desenvolvimento da natureza enquanto propriedade privada se expressa pela superação de qualquer aparência de relação pessoal que ela possa conter, e por sua redução à simples riqueza material. Essa superação se expressa no ocultamento dessas relações.

Existe ainda um descolamento da relação entre o político e o econômico nos termos do Estado de exceção permanente (ARANTES, 2007) que vivemos (ou nos termos de Mészáros, crise estrutural do capital). Essa relação é articulada decisivamente na economia capitalista, e substancia a servidão econômica, particularmente financeira, de como aparece concretamente a "crise ambiental". O tratamento dessa problemática, porém, é descolada desse termos e especialmente pormenorizada como uma problemática físico-ambiental. Ainda, como mercadorias ou recursos naturais, há um descolamento da sua forma mercadoria portadora de valor e grandeza de valor da sua expressão na forma preço: as mercadorias ambientais tem que auferir lucro para as empresas transnacionais interessadas ou para os Estados que detém o monopólio da outorga onerosa, sendo a apropriação privada intermediada pelas ações estatistas.

Articulado umbilicalmente à esse processo está o deslocamento dos conflitos de classe para a idéia abstrata de gerações futuras; também o deslocamento da apropriação das riquezas naturais que são apropriadas privadamente ou mediadas pelo Estado e as frações de classe que o amparam de modo privilegiado para a natureza, biosfera ou meio ambiente como bem comum (RODRIGUES, 2005). Desloca-se a problemática da produção para o consumo e não se faz a crítica da economia política da valorização e capitalização da natureza.

A guerra travada pelo capital para arrancar o campesinato da terra e para submeter a atividade agrícola ao lucro, da qual vivemos seus novos capítulos hoje em dia, repõe as permanentes violências fundadoras do modo de produção e das formas socioespaciais que lhe 
são próprias. Os dois mecanismos que são complementares à (essa) sede do capital são as expropriações, que tem por fundamento a instituição da propriedade privada da terra e dos recursos do subsolo, permitindo a apropriação das rendas; e o outro, que repousa sobre uma das afirmações fundadoras da Economia Política, a de que os elementos do mundo natural, outros que a terra e o subsolo, inicialmente abundantes ou em demasia para serem facilmente submetidos a um mecanismo de apropriação e exploração, a água e o ar e por extensão a natureza, seriam fontes inesgotáveis. Smith (1988) reflete sobre a apropriação da natureza e sobre sua transformação em meio de produção

O desenvolvimento do capitalismo, entretanto, envolve não um desenvolvimento quantitativo, mas qualitativo da relação com a natureza. Isto é meramente uma expansão linear do controle humano sobre a natureza, um alargamento do domínio da segunda natureza em prejuízo da primeira. Com a produção da natureza em escala mundial, a natureza é progressivamente produzida dentro e como parte da chamada segunda natureza. A primeira natureza é destituída do fato de sua primitividade, sua originalidade. A causa desta troca qualitativa nesta relação com a natureza repousa na relação alterada entre o valor-de-uso e o valor-de-troca. (...) Com o desenvolvimento do capitalismo em escala mundial e a generalização das relações de trabalho assalariado, a relação com a natureza é antes de mais nada uma relação de valor de troca. (SMITH, 1988:93-94)

A conclusão do autor é a de que nenhuma parte da superfície terrestre está imune à transformação em mercadoria. A natureza não é vista como natureza, mas como matériaprima.

A abundância da água é um dos fundamentos do desenvolvimento econômico: os serviços de saneamento e geração de energia estão relacionados a uma utilização maciça de volume e vazão de água e fomentam o aumento das taxas de lucros das empresas privadas. Nos países centrais do capitalismo essa utilização foi desenfreada, conforme analisam Oliveira (2007) e Petrella (2002). Rodrigues (2008) observa a virada no tratamento da abundância para a estratégia da escassez sob um prisma: os discursos oficiais. A ONU, por exemplo, em 1962 apontou que os recursos naturais eram vitais para o desenvolvimento econômico, todavia o desenvolvimento econômico dos países menos desenvolvidos poderia pôr em risco os recursos naturais. Em 1972 na $1^{\text {a }}$ Conferência da ONU sobre Meio Ambiente, expõe-se o esgotamento dos recursos naturais e traveste-se o debate como se fosse um conflito entre países desenvolvidos e subdesenvolvidos, escamoteando os interesses na implantação de industriais poluentes na periferia do sistema capitalista, além da exploração de seus recursos naturais. Em 1992 na $2^{\text {a }}$ Conferência sobre o Meio Ambiente e Desenvolvimento pautou-se o "desenvolvimento sustentável” como meta, norma e imposição para o futuro (CUSTÓDIO, 2005). Um dos resultados dessa conferência foi o documento 
denominado de Agenda 21, em que o fetiche do desenvolvimento sustentável se explicita fundamentado no discurso da "importância das ações globais e locais rumo à diminuição dos impactos da ação humana sobre o meio ambiente". Esse modelo é reproduzido e mundializado, chegando, inclusive, até uma escola na favela do Aço na periferia do Rio de Janeiro (a Agenda 21 escolar). O capitalismo se reproduz inclusive num processo de repassar e transferir os problemas que ele mesmo cria. As classes mais pauperizadas são alvos da sanha da reprodução econômica e também da reprodução dos discursos e ideologias.

A estratégia da raridade está forjada partindo-se de mais alguns fetichismos: a escassez e os limites da natureza. Forja-se a escassez para se desenvolver a propriedade privada das riquezas naturais, pois só pode ser propriedade aquilo que é tornado escasso, conforme já analisamos exaustivamente. A segunda metáfora refere-se aos limites como pontos de partida, no caso da natureza, limites de fertilidade e disponibilidade dos recursos. No modo de produção capitalista, o limite é o ponto de partida. O capital opera transformando o limite absoluto em limite relativo: os limites nunca são dados pela natureza, mas pelo capital, já que o capital é o limite de si. Como argumenta Salviatti (2010), o esgotamento ambiental contemporâneo, longe de demonstrar para os capitalistas a crise estrutural do capital que estamos imersos, recebe o mesmo tratamento que outros temas, tendo sua dimensão calculada em variáveis econômicas e financeiras, e aparecem nesse sentido expressões como custo de oportunidade, fatores de produção, eficiência econômica, em um nível estritamente econômico desarticulado da Política.

Smith (1988) reflete que na incontrolada tendência à universalidade, o capitalismo cria novos limites para sua produção e reprodução baseado na produção de uma escassez de recursos necessários, empobrecendo a qualidade dos recursos ainda não consumidos, criando novas doenças, desenvolvendo uma tecnologia nuclear que ameaça o futuro de toda a humanidade, poluindo totalmente o ambiente que nós devemos consumir para reproduzirmonos, e o processo diário de trabalho ameaça em muito a existência daqueles que produzem o essencial da riqueza social. Mészáros (2009) verificou extensamente esse quadro de subjugações.

O debate tem se encaminhado ainda no sentido de análise dos processos ecológicos (ou no caso da água, hidrológicos) ou institucionais sem estabelecer uma relação dialética entre exploração econômica e política da sociedade e da natureza ${ }^{68}$. Ouvida-se o que Marx já

\footnotetext{
${ }^{68}$ Percebemos os processos de expropriações que os moradores das favelas da periferia carioca sofreram e as conseqüências dessa profunda articulação entre a exploração econômica e política da sociedade e da natureza. No caso das Favelas do Rollas 1 e 2, se explicita a transformação do Rio de Janeiro de campo (sertão carioca
} 
argumentava: a missão civilizatória do capital criou a sociedade burguesa e a apropriação mundializada da natureza, estabelecendo-se como o vínculo "natural" da sociedade (associase a essas perspectivas a liberdade, a igualdade, o desenvolvimento, o direito, dentre outros, associados sempre a destituição dos vínculos com a terra e com a natureza e a propriedade da força de trabalho).

O capital cria assim a sociedade burguesa e a apropriação universal tanto da natureza como da própria relação social dos membros da sociedade. Daí, a grande influência civilizadora do capital; sua produção de um estágio social, em comparação com o qual todos os anteriores aparecem como meros desenvolvimentos locais da humanidade ou idolatria da natureza. Pela primeira vez, a natureza se converte puramente em objeto para a humanidade, em pura matéria de utilidade; cessa de ser conhecida como um poder para si mesma; e a descoberta teórica de suas leis autônomas aparece meramente como um ardil para subjugá-la às necessidades humanas, seja como objeto de consumo, seja como meio de produção. De acordo com essa tendência, o capital tende para além das barreiras e preconceitos nacionais, tanto quanto da veneração da natureza e da satisfação tradicional, confinada, complacente e incrustada das necessidades existentes, bem como da reprodução dos velhos estilos de vida. O capital é destrutivo ante tudo isso e constantemente o revoluciona, rompendo todas as barreiras que impeçam o desenvolvimento das forças produtivas, a expansão das necessidades, a diversificação do desenvolvimento da produção e a exploração e o intercâmbio das forças naturais e espirituais. (MARX, 2007: 362)

A mercadoria-água, síntese de múltiplas contradições, como outras mercadorias, apresenta na forma acabada o enigma do fetiche, o segredo da mercadoria, qual seja aquilo que Grespan (2010) denomina de dialética do esquecimento. A sociabilidade aparece numa relação entre coisas, o que passa pela instrumentalização da natureza e da relação entre homens autonomizados aparentemente sem relações sociais. Parece então que as coisas estão realizando os processos. E naturaliza-se os processos, esquecem-se quem produziu as mercadorias, negligencia-se a exploração e reafirma-se incessantemente o direito irrevogável e inalienável da propriedade privada.

com várias fazendas e pequenas propriedades) em cidade e metrópole. Essa relação é opacificada e muitas vezes alienada da própria história dos moradores dessas favelas. As elites cariocas buscavam até a década de 1960 fazendas e sítios na Zona Oeste do Rio de Janeiro, inclusive pela abundância de águas, resquícios das matas atlânticas, clima mais ameno. Com todo o processo de produção do espaço para a reprodução da classe trabalhadora a Zona Oeste cumprirá então um outro papel na divisão social do trabalho. As águas abundantes e límpidas foram poluídas pela expansão das atividades industriais e pelo processo de metropolização do Rio de Janeiro. Seus moradores vivenciam com a precariedade de reprodução da vida, inclusive quanto ao abastecimento de água. Analisamos também que as barganhas políticas das elites locais com a política da bica d'água é utilizada até os dias de hoje, a manutenção das raridades permanece como um instrumento de manutenção de poder. 


\section{5. $O$ cativeiro da terra e o cativeiro da água}

A questão da propriedade da terra preocupa os economistas, filósofos e historiadores há bastante tempo, e Karl Marx (1986) se perguntava por que os proprietários de terra tinham o poder de se apropriar de valores criados sem a sua intervenção. Martins (2010) disserta que a terra é um bem natural e não pressupõe trabalho na sua constituição, fundamento que a estabelece como equivalente de capital. Porém, quando apropriada privadamente, a terra garante ao proprietário o abocanhamento de uma fração da massa de mais valia global. Isto é, há uma modalidade de apropriação de riquezas por proprietários de terra, que nela produzem ou não, mas que recebem tributos sociais pela posse da terra nua: a renda da terra. O conjunto da sociedade paga pelo fato da classe dos proprietários de terra monopolizarem a terra, pois a renda que será paga ao proprietário não nasce na produção, ela somente será transferida a ele no momento da distribuição da mais valia, como analisou Martins (2010). Segundo Marx (1985), a propriedade de terras por parte de uns, o que implica a não-propriedade por parte de outros, é o fundamento do modo capitalista de produção. O capital não pode existir sem a propriedade de terras, pois que faltaria um elemento para a produção do capital ${ }^{69}$.

Para Martins (1986), a terra como mercadoria no capitalismo se realiza completamente diferente das demais mercadorias, pois a propriedade e seu sentido de utilidade não necessitam estar articulados.

a terra transformada em mercadoria tem efeitos bem diferentes das outras mercadorias que se caracterizam por serem produtos do trabalho humano. A terra é uma mercadoria completamente distinta das demais. A diferença está em que a terra não é produto do trabalho, é finita e imóvel. É uma mercadoria que não circula; em seu lugar circula o seu representante, o título de propriedade. O que se compra e vende não é a própria coisa, mas o seu símbolo. Todas as verdadeiras mercadorias se realizam na sua utilidade e na sua utilização; elas se realizam nas mãos de quem as possui e usa. A terra não é propriamente mercadoria, mas equivalente de mercadoria. Para que possa produzir renda - que é o seu uso capitalista - a terra não exige que o ter e o usar estejam juntos. Nas outras mercadorias, o ter é condição do usar e o usar é a realização do ter; no caso da terra, na sociedade capitalista (e é dela que estamos falando), não é necessário que estejam juntos. (MARTINS, 1986: 33-34)

A questão da água apresenta nesse momento uma relação diferente da terra enquanto mercadoria, pois a água flui, ela é móvel, se encontra em vários estados físicos da matéria e sua dinâmica apesar de finita é bastante complexa. Porém, as águas, e no caso analisado por Marx (1986) das quedas d'água, podem ser incorporadas a propriedade privada, pois são

\footnotetext{
69 "Os proprietários de mera força de trabalho, os proprietários de capital e os proprietários de terra, cujas respectivas fontes de rendimento são o salário, o lucro e a renda fundiária, portanto, assalariados, capitalistas e proprietários de terra, constituem as três grandes classes da sociedade moderna, em que se baseia o modo capitalista de produção." (MARX, 1986: 317).
} 
“condições favoráveis" à produção que possibilitam pela incorporação da renda fundiária uma margem maior de lucro.

(...) o preço da queda d'água é uma expressão irracional que dissimula relação econômica real. A queda d'água, como as terras, como toda força natural, não possui valor, pois nela não se materializa trabalho, e por isso não possui preço, que normalmente é o valor expresso pelo dinheiro. Onde não há valor, nada por isso mesmo se pode expressar por dinheiro. O preço da queda d'água não passa de renda capitalizada. A propriedade fundiária capacita o proprietário para apoderar-se da diferença entre o lucro individual e o lucro médio. (...) desse modo assume o aspecto de preço da própria forma natural. A própria queda d'água não tem valor, e seu preço, calculado em termos capitalistas, é mero reflexo do lucro suplementar extraído. (...) (MARX, 1986: 142-143)

No caso da queda d'água (que Marx analisou para demonstrar o caráter geral da renda diferencial comparando fábricas impulsionadas por máquinas a vapor e força hidráulica), a monopolização das forças naturais é condição para a incorporação ao capital da força produtiva natural do trabalho. Essa "situação vantajosa" demonstrada por Marx (1986) não acontece misticamente, ela se estabelece porque as riquezas naturais não estão disponíveis para todos, pois elas foram monopolizadas e só estão disponíveis aos seus proprietários. Marx continua demonstrando que, no caso da queda d'água, além de limitada a alguns proprietários, essa "força natural" pode ser aumentada (na visão do capital o que era só potência é posto em ato e se realiza aumentando a capacidade produtiva). O capital necessita dessas "condições favoráveis" preexistentes e opera selecionando aqueles atributos potencialmente vantajosos e transformando pelo incremento de trabalho, o que pode propiciar uma renda diferencial ainda maior. Esse processo alavanca o sobrelucro. Sendo assim, o seu direcionamento é o da monopolização, particularmente dos fragmentos do espaço potencialmente lucrativos, o que significa em sua contabilidade o aumento dos seus ganhos. Essa dinâmica monopolizadora observa as riquezas naturais como substrato em potência, como aumento de sua capacidade produtiva: ela é produzida pela natureza e é monopolizada, compondo uma renda diferencial aos seus proprietários, o que a articula umbilicalmente à terra. Então, o sobrelucro decorrido da monopolização da natureza, que está inserida na produção capitalista, não se origina do capital, mas de produções da natureza que podem ser monopolizadas. Assim, o sobrelucro que se origina dessa monopolização, ou seja, da condição dos proprietários da terra e da água de se apropriarem privadamente de condições favoráveis produzidas pela natureza, possibilita que a riqueza natural tornada recurso se transforme em renda fundiária. Para esse incremento de produção, transformando a natureza em matéria prima, exigem-se as expropriações de relações coletivas com a terra e suas riquezas naturais imbricadas. 
A água sacia a sede (e as demais necessidades) da comunidade quando propriedade coletiva. Porém, quando propriedade privada, sacia a sede dos proprietários de terra por uma drenagem ainda maior da fração da massa de mais valia global.

O capital cria uma forma particular de riquezas: o valor baseado no trabalho (ROSDOLSKY, 2001). Porém, existe “o valor dos agentes naturais" (terras agricultáveis, quedas d'água, minas, entre outros) que não são produtos do trabalho, mas que são objetos de monopolização, tendo por isso valor de troca, entrando assim nos cálculos dos custos de produção. Explica-se esse valor através da teoria da renda. A moderna renda da terra é uma criação específica do capital, a única criação que faz surgir um valor diferente de si mesmo, de sua própria produção. Sendo assim, para Oliveira (2007), o desenvolvimento contraditório do modo capitalista de produção, particularmente em sua etapa monopolista, cria, recria, domina relações não-capitalistas de produção como, por exemplo, o campesinato e a propriedade capitalista da terra. A terra sob o capitalismo, para o referido autor, tem que ser entendida como renda capitalizada. Marx (1986) afirma que a propriedade fundiária pressupõe que certas pessoas tem o monopólio de dispor de determinadas porções do globo terrestre como esferas exclusivas de sua vontade privada, com exclusão de todas as outras. A questão da apropriação privada das águas surge então inicialmente imersa nesse conjunto de debates, como "valor dos agentes naturais" ou "renda diferencial", objeto de monopolização e inserida nos cálculos dos custos de produção.

Os sentidos coletivos (comunais e comunitários) e os processos de humanização do homem em sua relação com a água são subsumidos pela propriedade privada As relações coletivas de direito da água em diversos países e em diversas racionalidades diferentes da capitalista (como os povos indígenas, por exemplo) apresentam profundas raízes com sua história e sua relação com a natureza. Há ainda uma conexão latente, entre os povos e as águas, "sociedade" e "natureza", e essas relações não são externas, pois compõem mitos de origem, cosmologias, formas de reproduzir a vida. Estas constituem, porém, obstáculos para a instituição da propriedade privada e cabe ao Estado contornar essa situação.

Assim, a instituição dos marcos jurídicos de propriedade é realizada, evitando-se a todo custo a utilização do termo "propriedade", aparecendo em seu lugar termos como "uso", "gestão", “outorga", "direito de uso", "concessão", "prestação de serviços". Essas telescopagens ocultam apenas discursivamente a apropriação capitalista da água que ocorre concretamente. Não obstante, retoma-se que a propriedade da terra está imbricada à propriedade da água e o domínio da terra e dos povos implica o domínio da água, pois, não se 
pode olvidar, no momento de acirramento das lutas de classe, que a terra sem água é estéril. (TOVAR, 2004; PORTO-GONÇALVES, 2006).

A forma de "regular" e "normatizar" o acesso à água estabeleceu-se imbricado ao domínio sobre a terra. Porém, com a incapacidade física e técnica de tomar pela força e vedar o acesso à água da mesma forma que se fazia com a terra, as organizações sociais baseadas no regime de propriedade foram estabelecendo sistemas legais e de controle de acesso á água que, de alguma forma, se lhe assemelhavam. (TOVAR, 2004). Todos os sistemas jurídicos de direito da água no momento atual do modo de produção capitalista estabelecem as conexões entre Estados e empresas privadas, diretamente associada as monopolizações e aos interesses das classes sociais.

A monopolização das águas, porém, é complexa e exige uma intrincada trama, aplicável essencialmente à água "doce" de rios, lagos, aquíferos subterrâneos ou nascentes, como regulações sobre as "águas privadas" e "águas públicas" (comuns, administradas pelo Estado). A água é um bem comum administrado pelo Estado e cedido para interesses privados através de outorga onerosa. Porém, o Estado não é de todos. O Estado mantém seu caráter classista e aprofunda os conflitos de classe, haja visto que é ele quem controla quem poderá ou não receber a outorga de água. Inúmeros casos reforçam seu caráter expropriatório e sua servidão econômica e financeira (PAULANI, 2008) aos interesses privados. As circunstâncias históricas, porém, contribuíram para que esse processo fosse ocultado sob o véu alienante do "bem comum" realizado pelo aparelho do Estado.

Interessa-nos particularmente discutir a questão da "publicização da [propriedade da] água" no Brasil (GOMES, 2010), para tratarmos dos aspectos da monopolização capitalista da água como um movimento que desdobra o cativeiro da terra no Brasil. Convém nesse intento retomar historicamente o arcabouço jurídico que resguardou e salvaguardou tal apropriação, o que faremos mais adiante.

O advento da propriedade privada foi retratado particularmente por Marx (1985) na Inglaterra e por Martins (2010), Oliveira (1997; 2007), Silva (2008), dentre muitos outros no caso brasileiro. Nos autores supracitados, destaca-se, fundamentalmente, a instituição da Lei de Terras em 1850 e seus desdobramentos, por exemplo, os inúmeros casos de grilagem de terras que acompanham a história fundiária brasileira do período colonial à contemporaneidade, da terra como domínio público (sesmarias) ao seu domínio privado. Com os cercamentos dos campos no caso inglês, transfigura-se a terra de um recurso comum de uso comunitário em um bem privado, ou seja, a "cerca" (ou a instituição da propriedade privada) tem o objetivo de excluir o restante da sociedade do seu uso (TEIXEIRA, 2007). No caso do 
Brasil, com a instituição do cativeiro da terra, ou seja, na passagem da renda capitalizada no escravo para a renda territorial capitalizada, recriam-se as condições de sujeição do capital ao trabalho, engendrando os mecanismos sucessórios da coerção física e da coerção econômica articuladas e o imaginário da ascensão social pelo trabalho (MARTINS, 2010: 47-50). Para Martins (2010), se no regime sesmarial da terra livre o trabalho tinha que ser cativo, num regime de trabalho livre a terra tem que ser cativa. Silva (2008) argumenta que uma das características da constituição da propriedade da terra no Brasil é que a propriedade territorial se constituiu fundamentalmente a partir do patrimônio público, e a autora esclarece as condições da passagem das terras públicas para o domínio privado.

Silva (2008) argumenta ainda sobre as articulações entre os proprietários de terra e o Estado demonstrando que a Lei de Terras (1850) normatizou o processo de aquisição de domínio sobre as terras e que tal lei formou o arcabouço jurídico dentro do qual se constituiu a moderna propriedade fundiária. Esse processo de consolidação da propriedade privada é mediado pelo Estado e vinculado à consolidação do Estado nacional brasileiro. Compreendemos que esse processo, guardados os limites das derivações históricas, apresenta similaridades com a normatização do domínio da água. Analisamos que a constituição do arcabouço jurídico (e seus desdobramentos) - a Constituição de 1988 e os marcos regulatórios que institucionalizam os termos constitucionais - estabeleceu que a propriedade da água pertença ao Estado (como um patrimônio público, um “bem comum”). O Estado, então, irá monopolizar a propriedade da água e entregá-la ao domínio privado por meio da outorga onerosa da água (pois na constituição a água é apresentada como portadora de um "valor econômico"). Esse movimento ocorre no momento em que se encerrava o período da ditadura civil-militar (de 1964 à 1985), em que uma "renovação" do Estado estava acontecendo via construção de uma nova Carta Magna e os interesses de classe estavam outra vez expressando as novas demandas institucionais na constituinte.

Dito de outra forma, vemos que a propriedade privada da terra está historicamente articulada ao solo e ao subsolo, porém novos movimentos de instituição de propriedades têm surgido, por exemplo, com a Constituição Federal de 1988, Lei de Concessões, Plano Nacional de Recursos Hídricos de 1997, Criação da Agência Nacional das Águas, Agenda 21, privatização do setor elétrico, privatização dos serviços de água e esgoto, Política Nacional de Mudanças Climáticas, dentre outros.

No momento em que ainda se pensava que se instituindo os marcos de propriedade da terra todos os demais estavam sujeitos à essa instituição, não se intuía que era preciso regularse o domínio sobre o solo, o subsolo e mesmo o ar. A condição dos proprietários estava dada, 
o usufruto e a pilhagem das riquezas naturais estavam dados, porém o período histórico se modificou. Esse aparente desleixo não é fortuito: os proprietários de terra e os proprietários de capital, no caso brasileiro transfigurados muitas vezes no mesmo sujeito, se asseguravam no direito de propriedade e no aparato do Estado para assegurar a posse sobre a terra em todos os seus termos.

Henkes (2003) e Gomes (2010) mostram que houve no Brasil uma quantidade razoável de leis, decretos, emendas e ordens régias que regularam a posse e a propriedade da água durante o Período Colonial e Imperial ${ }^{70}$, porém compreendemos que somente a partir do Código Civil de 1916 se explicitam embrionariamente os caminhos da passagem da água como domínio estatal e público para o domínio privado ("particular”).

O artigo 526 do Código Civil apresenta a seguinte noção de propriedade: “A propriedade do solo abrange a do que lhe está superior e inferior em toda a altura e em toda a profundidade, úteis ao seu exercício". A premissa que embasa o Código é de que a propriedade do solo abrange tanto o que está na superfície quanto no subsolo, e tal lei assegura o direito pleno da propriedade: solo, subsolo, águas e ar. Estabelece, nesse sentido, um princípio amplo sobre a utilização "particular”. No artigo 565 estabelecia-se que depois de satisfeitas as necessidades de seu consumo, o proprietário não poderia "impedir o curso da água pelos prédios inferiores”. Essa aparente contradição nos parece resolvida ao se relembrar que não havia grande preocupação com a apropriação coletiva da água, pois estava garantido o direito à propriedade privada da terra, portanto também das águas. As expropriações eram nesse sentido regulamentadas. Logo, se a terra pertencia a seu proprietário a água também lhe pertencia.

O Decreto 24.643 de 1934, mais conhecido como Código das Águas, estabelece que quando as águas não forem definidas como "águas comuns ou públicas” são consideradas de posse daquele que os detém em sua propriedade: em suma propriedade privada. Assim, o artigo 8 do referido código referenda que "são particulares as nascente e todas as águas situadas em terrenos que também o sejam, quando não forem classificadas como águas comuns ou públicas”. A legislação brasileira, em especial o Código de Águas, regulamenta as águas visando assegurar a propriedade ao setor energético (SEABRA, 1987; HENKES, 2003). Corroboram-se tais fatos verificando-se o elevado número de usinas e centrais hidrelétricas criadas no país neste período e também pelo fato de que as disposições do Código de Águas

\footnotetext{
${ }^{70}$ Ordenações do Reino (alvará de 1804), Constituição do Império, de 25/03/1824, Lei de $1^{\circ}$ de outubro de 1829 que disciplinou sobre as atribuições das Câmaras Municipais na construção de aquedutos, chafarizes, poços e tanques e esgotamento de pântanos e qualquer estagnação de águas infectas, Ato Adicional 16 e a Constituição Republicana, de 24/02/1891 (HENKES, 2003).
} 
referentes à preservação, conservação e recuperação dos recursos hídricos não foram regulamentadas, ao contrário das disposições referentes à produção energética (HENKES, 2003; ROCHA, 1996; CUSTÓDIO, 2010).

O Código de Águas, promulgado em 1934 pelo Estado, regulamentou a fixação de tarifas cobradas pelas concessionárias, determinando também a limitação do lucro da concessionária ao nível de $10 \%$ de capital investido avaliado segundo o princípio histórico (ROCHA, 1996), a racionalização dos recursos hídricos do país e o reequilíbrio da política de outorga de concessão para a produção e distribuição de energia elétrica, o que ocasionou conflitos com as frações de classe ligadas ao setor energético. Não obstante, esses fatos atrasaram o processo de promulgação do Código de Águas pelo privilégio que a Light detinha no serviço de energia hidrelétrica em detrimento ao abastecimento de água (VICTORINO, 2002). A tendência ao nacionalismo no contexto do Governo Vargas e a centralização no âmbito federal de decisões na área de recursos estratégicos, cujo ápice se dá com a promulgação do Código de Águas em 1934, era latente (VICTORINO, 2002). Nesse sentido, a Light precisava formar uma imagem mais positiva junto à população, de forma a ter algum respaldo político, e, para tanto, empenhou-se num projeto de publicidade explícito mantendo as práticas de manipulação de águas e monopolização de terras.

O setor energético conseguiu comandar de modo praticamente soberano as grandes decisões sobre o aproveitamento da mercadoria-água no Brasil devido principalmente ao fato de ter consolidado o que Araújo (1988: 48 apud VICTORINO, 2002) chamou de "bloco empresarial-político do setor energético", que tem sua origem na história do grupo Light \& Power (SEABRA, 1987; VICTORINO, 2002). A construção desta fração de classe capitalista articula seus interesses no aparelho do Estado. E esse movimento relaciona-se com a história da transformação da água em mercadoria.

A partir da segunda metade do século XX, com o processo de industrialização no Brasil, a água passou a ser alvo de mais disputa e mais processos de monopolização, de modo que o conflito de classes em torno da água se apresenta mais explicitamente, assim como a concorrência entre os capitalistas e os proprietários de terra. Para a instituição do pacote da Revolução Verde, entre as décadas de 1950 e 1960, por exemplo, a irrigação foi um fator importante para o desenvolvimento do agronegócio brasileiro, ocorrendo um conflito entre os capitalistas, como verificou Ioris (2004).

Porém, Gomes (2010) aponta que o Código de Águas e o Código Civil garantiam múltiplas formas de propriedade. A propriedade estatal, coletiva e privada previstas nessas legislações eram empecilhos para a transformação plena da água em mercadoria e para o 
desenvolvimento desse mercado, ao prever o uso coletivo e interditar a troca por outros produtos ou seu equivalente em dinheiro.

Com a crise do capital manifestada na crise ecológica e com as movimentações de criação de um mercado da água, os capitalistas perceberam a oportunidade de criação de novas mercadorias para assegurar fatias ainda maiores de renda fundiária e de sobrelucro, institucionalizando novas propriedades, realizando-se outras expropriações e criando mais cercamentos. Exige-se nesse intento que o poder político do Estado se efetive nesse processo para assenhorar as classes sociais que os dá sustentação de partir na frente nesse mercado rentista e lucrativo. A monopolização da água, efetivada pela constituição de 1988, entregou para o domínio dos Estados da federação a propriedade da água. Gomes (2010) demonstrou que esse movimento obrigou a aquisição da água por meio do mercado, e as águas particulares, de uso privado, comunal ou coletivo tornaram-se patrimônio estatal. O Estado exerce duas funções primordiais para a garantia desse movimento: legalizar a expropriação da água e impedir o uso direto da água pela coerção estatal.

A Constituição Federal de 1988 modifica o sentido da propriedade privada da água com a "publicização" do seu domínio, e o Estado toma para si a figura de monopólio da concessão jurídica da titularidade das águas nos artigos que se referem às "águas como bens da União" (artigo 20,III) ou "dos estados" da federação (artigo 26,I). O artigo 20, inciso III explicita tais afirmações: "são bens da União os lagos, rios e quaisquer correntes de água em terrenos de seu domínio, ou que banhem mais de um estado, sirvam de limites com outros países, ou se estendam a território estrangeiro ou dele provenham, bem como os terrenos marginais e as praias fluviais”. A Constituição Federal ainda regula as águas pertencentes aos estados (artigo 26, inciso I) estabelecendo que "as águas superficiais ou subterrâneas fluentes, emergentes e em depósito, ressalvada neste caso, na forma da lei, as decorrentes de obras da União". Todavia, o antigo proprietário particular da água passa da condição de detentor parcial da água à usuário privilegiado em teoria. Na prática, mesmo que não haja a titulação e a possibilidade de alienação da água, ou seja, que essa titulação seja vendável, ele detém o monopólio. Esse processo realiza uma privatização da água à brasileira, via sua outorga. Oculta-se o problema e desvia-se do fato da questão da titulação ser uma forma de propriedade. Prova desse imbróglio é que o título é a figura jurídica da monopolização, pois nem todos recebem o título de usuário de água. O Estado irá mediar essa relação através das concessionárias de abastecimento fazendo com que todos se reportem a ele no momento de utilização da mercadoria-água. Essas concessionárias, todavia, prestam o serviço de modo absolutamente desigual, conforme constatamos nas favelas da periferia carioca, nas quais há 
uma massa de proletários urbanos com o abastecimento de água cotidianamente negado. A prerrogativa estatal de possível destituição da concessão dificilmente ocorre, como argumentam Ioris (2004); Revers e Malvezzi (2009) e Porto-Gonçalves (2006).

Percebe-se que a legislação em seus incisos revoga o "direito assegurado" de "particulares" no que se referem a jazidas, minas e demais recursos minerais e os potenciais cursos d'água para fins de energia hidrelétrica, passando para União as prerrogativas legais sobre esses territórios. A Constituição Federal ainda regula que as águas subterrâneas pertencem as unidades da federação e as águas de chuvas pertencem ao Estado (dependendo do caso à União ou aos estados membros da federação), dependendo do local de armazenamento, pois o represamento impediria o seu curso fluvial natural.

No que pese a definição de água, observou-se a compreensão da água como raridade (ou seja, a água como recurso escasso) e de necessidade de todos. Esse valor de uso é precedente, é anterior à forma de recurso escasso. Essa não é uma colocação meramente semântica, ela irá justificar toda sua constituição como bem de mercado. Nesse sentido, assegura-se ao Estado a titularidade a fim de "garantir uma sociedade menos injusta e desigual" (Constituição Federal de 1988, artigo 3, incisos II e III). A lei n 9.433 - 08/01/1997 - regulamenta o artigo 21, XIX da Constituição no seu artigo 1,inciso I - "a água é um bem de domínio público".

A retirada das águas da titularidade privada e a sua "inclusão como propriedade estatal está associada com o princípio constitucional de que a propriedade, embora assegurada (artigo 5,XXII CF) atenderá a sua função social (art.5,XXIII CF)" (GOELLNER, 2008). E que a água tem um valor econômico, pois é um recurso escasso.

Todavia, a função social do capitalismo é a reprodução ampliada do capital e sua sede obstinada é transformar as mais variadas esferas da vida em mercadoria, em monopólio comercializável pela troca, tal como um Midas em que tudo o que toca vira mercadoria.

O Estado tem função fundamental organizando e normatizando a propriedade. Tornando a água patrimônio público é o Estado que vai regular quem e com que finalidade se utiliza a mercadoria-água, seu papel de mediar conflitos em favor dos interesses de sua reprodução e reprodução de suas classes. No momento em que a propriedade ainda pudesse ser coletiva, a criação do mercado e do negócio da água ainda não tinha a sua principal condição: a monopolização. Para Gomes (2010), antes da Constituição de 1988, ainda haviam brechas jurídicas e um emaranhado de leis, códigos e legislação que estabeleciam múltiplas possibilidades de leitura de quem seria o proprietário de águas no Brasil. A partir de 1988 estão dadas as possibilidades da expropriação do direito à propriedade da água para 
simultaneamente se outorgar esse bem, por meio do Estado, à um capitalista ou um proprietário de terra, para que este, de forma onerosa, auferisse lucros na revenda ou na confirmação plena de utilização da renda diferencial que aumenta exponencialmente seu sobrelucro.

Custódio (2005) analisou que a descentralização administrativa (com especial destaque para os municípios) foi um dos marcos da Constituição Federal brasileira. A autora relembra que o momento de surgimento da Constituição ocorre coetâneo ao espraiamento da doutrina neoliberal que enfatiza processos de privatização, flexibilização (maior exploração do trabalhador) das leis trabalhistas, participação meramente burocrática e institucionalizada e ampla abertura de mercado para empresas transnacionais. Com esse rearranjo federativo, com ênfase na esfera municipal, as frações de classe capitalistas moveram-se com ampla organização interna tendo em vista abocanhar várias infra-estruturas e serviços que estavam sendo retomadas pelo município e privatizadas. Foi o que aconteceu em inúmeras cidades nos casos do abastecimento de água e do esgotamento sanitário ${ }^{71}$ (CUSTÓDIO, 2005; VARGAS e LIMA, 2005). Custódio (2005) observa ainda que a questão das águas está atomizada em inúmeros ministérios (Ministério das Minas e Energia, Ministério do Meio Ambiente, Ministério da Agricultura, Ministério das Cidades, Ministério da Saúde, Ministério do Desenvolvimento Agrário) com perspectivas ideológicas, políticas e econômicas muito diferentes, inclusive porque cada ministério se reporta a frações de classes muito específicas.

Ioris (2004) sintetiza tais perspectivas ao analisar que os setores de geração hidrelétrica e os serviços de água e esgoto passaram de uma situação de controle municipal e operação privada, no começo do século XX, para um crescente controle pelo governo federal e operação estatal após a Revolução de 1930. Essa situação começou a se reverter no final da década de 1980 (IORIS, 2004) com a institucionalização dos marcos de monopolização da água com caráter de bem comum. Na década de 1990 a privatização segue um caminho e de certa forma um retorno, quando fica ainda mais monopolizada sob a forma operação privada institucionalizada e possibilitada pelo Estado (outorga onerosa de água). Os movimentos analisados por Ioris (2004) de "desenvolvimento hídrico no país" são em nosso entendimento a forma institucional de entrega via Estado do patrimônio público monopolizado ao domínio privado da água (em linhas gerais diríamos, baseados numa periodização proposta por

\footnotetext{
71 Esses processos ocorreram, por exemplo, em inúmeras tentativas de privatização da CEDAE. Como a privatização strictu sensu não se efetivou, várias cidades do Estado do Rio de Janeiro privatizaram os serviços de água e esgoto. Como verificamos, ocorreu inclusive a tentativa de privatizar somente as áreas lucrativas e valorizadas da cidade do Rio de Janeiro. (Ver capítulo 1)
} 
(IORIS, 2004), que há um movimento de privatização até 1930, nacionalização até 1988, reprivatização - monopolização do Estado para o domínio privado) que foram impulsionadas pela conversão da água em uma mercadoria comercializável e sua incorporação à lógica de acumulação de capital. Ao longo do século XXI ocorreram as garantias das condições necessárias para a permanência da expansão da infra-estrutura e dominação política da reafirmação das frações de classe interessadas na renda fundiária e no sobrelucro a partir da mercadoria-água.

\subsection{Conclusão ou a reafirmação das três classes capitalistas pelo Estado}

Nesse capítulo analisamos os fetiches nos debates sobre a questão da água. Discutimos os fetiches da mercadoria-água, do Estado e do mercado ambiental, do desenvolvimento sustentável e do bem comum e a monopolização estatal que repassa a dominação privada das águas no Brasil. Os marcos legais da passagem do patrimônio público para domínio privado estão ganhando regulamentação tendo em vista a criação da Política Nacional de Recursos Hídricos, da Lei de Concessões, das agências nacionais de água (ANA) e energia (ANEEL), Lei do Saneamento Básico de 2007, dentre tantas outras leis estatais e municipais. Conclui-se que a expropriação constitucional e seus marcos regulatórios para institucionalização das prerrogativas constitucionais foi deveras conveniente para os interessados na monopolização da água (privatização dos serviços de água e esgoto, privatização do setor energético, latifundiários, empresas privadas do comércio de água engarrafada, etc.). A obrigatoriedade de todos consumirem a mercadoria-água das concessionárias estatais (de economia mista, na velha promiscuidade dos interesses privados regulando os serviços públicos) e das empresas privadas que "recebem" a outorga é uma fonte geradora de sobrelucro. Tal como argumentam Gomes (2010) e Ioris (2004), esse também nos parece o sentido da evolução legislativa sobre a água. Porém, acreditamos que há ainda um passo adiante: o Estado confirma sua reprodução no aprofundamento dos conflitos de classe e na reafirmação das três classes fundamentais do capitalismo: proprietários de capital, proprietário de terra e proprietários de força de trabalho.

Assim a questão da manutenção da ausência do abastecimento de água é uma das questões que têm a potência de explicitar os conflitos de classe no capitalismo e um prisma de observação de suas periódicas mutações. Altera-se a aparência, modificam-se as formas, mas a essência permanece a mesma: reprodução ampliada do capital. Porém, em todos os fragmentos do espaço há resistências e lutas contra essa dominação privada e sobre o caráter classista do Estado capitalista. Essas batalhas explicitam a luta de classes que permanece viva em incontáveis casos: Guerra da Água na Bolívia, luta dos atingidos por barragens (MAB) no 
Brasil, lutas pela água pública e coletiva na Índia, na Argentina, em Uganda, no Uruguai, etc... A sede do capital não cessa, porém a luta potencialmente revolucionária também não. 


\section{Considerações finais - ou como o capitalismo se travestiu de verde e a sede de reprodução do capital voltou-se para a questão das águas}

Chegamos a segunda década do século XXI e a questão do abastecimento de água está longe de ser resolvida, muito menos universalizada. A água tornou-se uma mercadoria e é também uma raridade encoberta sob o véu da "escassez absoluta" e da "crise da água". Essas relações, entre as águas e a crise, quando explicitadas, são um dos prismas para observarmos um dos fetiches do capital, ou seja, como o capitalismo se travestiu de verde no mundo contemporâneo. Retomar Karl Marx nesse sentido é fundamental, pois lembremo-nos que o autor já prenunciava um dos desdobramentos do capitalismo: “a produção capitalista volta-se para a terra só depois que esta foi exaurida pela sua influência e depois que as suas qualidades naturais foram por ela devastadas" (MARX, 1985). As "riquezas naturais" pilhadas pelo capital e "destruídas" pelo seu uso transformam-se tautologicamente em mercadoria. Nesse intento, tornar raro o que outrora foi abundante é um dos movimentos de sua produção e reprodução. Transformam-se desmedidamente todas as relações e produtos em bens mercantilizáveis e se instituem marcos de propriedade privada onde for (im)possível.

Tal como vários outros elementos fundamentais para a reprodução da vida, a água não está disponível para uma quantidade inacreditável de pessoas. Exemplos dessa barbárie capitalista podem ser expressos nos seguintes dados: um bilhão e meio de pessoas não tem acesso à água potável em quantidade suficiente (ou seja, não possuem ao menos 20 litros de água potável por pessoa ao dia), dois bilhões de pessoas não tem acesso à água de qualidade adequada (PETRELLA, 2003), e dois bilhões e meio de pessoas não têm acesso a nenhum tipo de saneamento. Existem ainda aproximadamente quase dois bilhões e meio de pessoas que contraem a cada ano doenças de veiculação hídrica (VILLAR e RODRIGUES JR, 2006 ).

Ao analisar as favelas da periferia carioca constatamos momentos dessa problemática. Esses fragmentos do espaço convivem cotidianamente com o abastecimento de água negado. Porém, não só a ausência de abastecimento de água foi observada: há ainda a intermitência (a água que só chega durante uma parte do dia), a irregularidade (moradores sem água durante dias, semanas e mesmo meses), a desconfiança sobre a qualidade e sua potabilidade, infraestrutura precária e auto-construída de ligações clandestinas e cortes do serviço pela falta de pagamento. 
A água porta um valor de uso indispensável e é condição sine qua non para saúde, alimentação, higiene, produção e reprodução, ou seja, é um meio de vida que possibilita a realização das necessidades básicas e é fulcral à subsistência e à humanização do homem.

A água, porém, é fundamental também para a reprodução econômica do capital, e vem sendo cada vez mais instituída como uma mercadoria, mediante sua valorização econômica e criação de um lucrativo mercado de águas. Grandes empresas privadas em vários setores da economia tem se assenhorado de concessões públicas de serviços e infra-estruturas ligados a água, por exemplo, a partir da privatização do sistema hidrelétrico e da privatização dos serviços e infra-estruturas de saneamento. Além disso, os proprietários de terra, especialmente os latifundiários, tem se interessado cada vez mais por políticas públicas e outorgas de água que aumentam sua renda diferencial e o sobrelucro de suas produções a partir dos projetos de transposição de bacias hidrográficas, irrigação de suas produções, construções de cisternas em propriedade privada, etc.

Em suma, a água entrou nos circuitos de reprodução econômica como uma mercadoria valiosa. O mercado de água gira em torno de um trilhão de dólares por ano com uma ampla disputa por mananciais de água. Estão particularmente interessadas nessas riquezas, nos processos jurídicos de instituição de propriedade privada e nas legislações que apoiem sua exploração as empresas de água envasada ${ }^{72}$; empresas transnacionais prestadoras de serviços anteriormente públicos que buscam mais aberturas de mercado nos serviços de água e esgoto $^{73}$ e maiores aberturas de capitais de empresas estatais; e proprietários de terra que batalham por marcos regulatórios que envolvam titulações de propriedade privada e buscam que se aprovem mais expropriações de propriedade coletiva da água. Além da disputa entre os capitalistas há os camponeses, indígenas, quilombolas que observam uma relação complementar entre terra e água para a manutenção de suas vidas e de suas produções (em conflitos de classe com os proprietários de terra e capital). E os habitantes da cidade,

\footnotetext{
${ }^{72} \mathrm{O}$ mercado mundial de águas envasadas produziu mais de 210 bilhões de litros e lucrou mais de US\$ 100 bilhões de dólares. Em 2007 o consumo mundial de água envasada superou o de refrigerantes gaseificados, conforme argumenta Carlos Alberto Lancia, presidente da Associação Brasileira de Indústrias de Águas Minerais (Abinam).

${ }^{73}$ A GDF-Suez (com o seu braço de prestação de serviço de água e esgoto, a Suez Environnement) é a líder mundial de abastecimento de água, atendendo atualmente cerca de 91 milhões de pessoas com água, no esgotamento sanitário 61 milhões de pessoas e 50 milhões em coleta de lixo. A GDF-Suez atua em mais de 100 países e seus capitais giram em torno de US\$ 110 bilhões de dólares. Na lista das maiores empresas estatais da Revista Forbes a GDF-Suez encontra-se na $27^{\circ}$ colocação, valendo aproximadamente US $\$ 85$ bilhões de dólares. A Veolia (com o seu braço de prestação de serviço de água, a Veolia Water) é a segunda maior empresa nesse ramo e atende atualmente cerca de 132 milhões de pessoas com água e esgoto. A companhia atua em 57 países e os capitais giram em torno de $€ 10$ bilhões. As informações foram obtidas nos sites das empresas. Freitas (2004) afirma que a Suez (atual GDF-Suez) e a Vivendi (atual Veolia) detêm cerca de 70\% do mercado mundial de água.
} 
especialmente os mais pobres, que convivem cotidianamente com o abastecimento de água negado. Compreendemos que, quando se maneja a água para fins privados, se maneja a vida cotidiana dos mais pobres, envolvendo mais uma jornada de trabalho pela busca da água potável.

Diferente do que se propaga, a privatização do abastecimento de água mantém os índices de ausência, ineficiência e racionamento e tem sido a explicitação e o reforço de uma espoliação especialmente perversa nas favelas e periferias das metrópoles capitalistas ${ }^{74}$. Olvida-se intencionalmente que a lógica do capital não é somente a criação de necessidades e de conformação de valor de uso social, que no caso da água é vital, mas a reprodução do capital. Assim, o que menos importa é a mercadoria que se conforma no processo produtivo. A produção desde o seu fundamento é voltada para a troca no mercado, a mercadoria trocada substancia-se em dinheiro que é reinjetado na produção para se auferir mais lucro, para se valorizar o capital. O sobrelucro é o motor, a sanha do capitalista. Assim, a mercadoria-água como produto do processo de produção de água potável é a mesma água que sacia as necessidades do capitalista, do trabalhador, do camponês e do latifundiário. Essa relação explicita claramente que há uma divisão de classes no abastecimento de água no capitalismo, pois são nas periferias das metrópoles, nos assentamentos rurais, nas áreas mais pobres e nos países mais miseráveis em que a situação é mais problemática.

Os interessados na valorização econômica da água e de abocanhamento de frações de massa de mais valia global através da renda da terra estão construindo uma produção discursiva da escassez cada vez mais vinculada na Academia e na mídia, cumprindo um papel de difusão de uma ideologia explícita: a realização da vida acontece através do capital, substanciado no dinheiro e mediado pela troca. A água como valor econômico e bem escasso é praticamente um mantra entoado para a construção de um pensamento único sobre o capitalismo ("verde"?) e sobre a crise "ambiental". A questão do saneamento é uma questão social que se articula à urbanização crítica e a crise estrutural do capital, não é algo descolado desse debate e dessas premissas.

O ocultamento da barbárie capitalista manifestada nessa produção discursiva da escassez é intermediado pelo aparelho do Estado que aprofunda ainda mais as classes sociais e posterga a resolução dos problemas, lidando de modo paliativo e cada vez mais

\footnotetext{
${ }^{74}$ Ver Dagdeviren e Robertson (2009). Para os autores a privatização e comercialização dos serviços de saneamento significou queda nos investimentos públicos em água e esgoto, principalmente nas áreas de moradia das classes sociais mais pobres (favelas e periferias). A lacuna deixada pelo Estado não foi coberta pelas empresas privadas.
} 
financeirizado com a produção social do espaço urbano e de suas infra-estruturas e serviços ${ }^{75}$. Nesse papel articulado entre capitalistas e proprietários de terra metamorfoseados entre si e com o Estado o descolamento da questão de seu fundamento se coloca: a crise estrutural do capital se manifesta então como se fosse uma crise ecológica, e mais ainda, crises específicas de cada dinâmica ecológica: crise climática, crise da água, buraco da camada de ozônio, escassez de terras agricultáveis, etc.

Por outro lado, mas nesse mesmo prisma, as crises aparecem autonomizadas no plano individual e absolutamente fetichizadas, e os indivíduos aparecem cada vez mais atomizados numa sociedade do consumo desmedido realizada como se as mercadorias se trocassem no mercado sozinhas: aparecem então consumo responsável, consumo consciente, sustentabilidade, desenvolvimento sustentável, produtos verde. Consideramos, porém que o problema é mais complexo. A situação permanentemente crítica em que a vida cotidiana está imersa não pode e não é resolvida na autonomização das formas e dos indivíduos. Nesse sentido, ao pesquisar e vivenciar um conjunto de situações nas favelas da periferia na metrópole periférica do capitalismo constatamos que esses fragmentos do espaço portam a condição de explicitar a crise capitalista. A urbanização que o capitalismo engendra baseia-se no fundamento da realização dos negócios urbanos, pois a viabilidade dos projetos urbanos é um eufemismo para saber em quais fragmentos do espaço se possibilita o sobrelucro. $\mathrm{O}$ aparelho do Estado irá atuar na mitigação, na pacificação e na postergação dos problemas na tentativa de se apartar os conflitos de classe na periferia. Porém, o conflito sempre aparece, pois não é possível de ser resolvido nas condições apresentadas pelo modo de produção capitalista.

A reprodução do capital está cada vez mais acelerada, porém cada vez menos consegue expandir seus sobrelucros, obter as mesmas taxas de mais valia e os mesmos índices de consumo. A reprodução necessita então de níveis ainda maiores de exploração, e a população da periferia, ao invés de descartável (pois na aparência do processo é assim que se apresenta) é cada vez mais considerada necessária, visto que são consumidores precários de mercadorias que cada vez mais estão inseridos marginalmente nesse processo.

Os elementos da reprodução da vida estão sendo cada vez mais mercantilizados, os usos coletivos cada vez mais criminalizados e essa população pauperizada ao menos serve como exército de reserva ou como desempregados consumidores, que cada vez mais não conseguem realizar-se na troca. Porém, ainda há a possibilidade de endividamento desse

\footnotetext{
${ }^{75}$ O Programa Favela Bairro é um exemplo categórico desse processo, conforme analisamos, especialmente nas favelas das Três Pontes e Divinéia na periferia carioca.
} 
proletariado de trabalho precário através da financeirização, que expande seus tentáculos cada vez mais para as periferias, realizando mais urbanizações de favela, mais cidadania via pagamentos dos serviços essenciais, mais consumo de supérfluos, de regularização fundiária, entre outros.

Certamente é na periferia em que se explicitam as contradições. É nesses fragmentos que o capitalismo e suas telescopagens apontam os limites da acumulação e da reprodução desmedida. É nas periferias que o discurso da igualdade mostra mais escancaradamente a igualação dos desiguais, demonstração de que a igualdade é jurídica e formal e atende aos interesses dos proprietários de terra e de capital. É nas periferias que a liberdade mostra-se como a expropriação dos meios de produção e revela-se como liberdade do trabalhador para vender sua força de trabalho de modo cada vez mais precário. E é nas periferias que a fraternidade se coloca pela imposição do desenvolvimento local/comunitário de caráter ongueiro, que apazigua as lutas sociais, que coloca todos como atores sociais, tanto os opressores quanto os oprimidos.

Essas tessituras, todavia, tem reentrâncias, e não são de modo algum uma lei geral, uma tendência de mão única. Dialeticamente, é nesses lugares que a vida cotidiana e a resistência acontecem, que as lutas se expressam de modo impossível-possível, portadoras de caráter revolucionário.

Nas favelas da periferia do Rio de Janeiro está explícita a figura do expropriado da terra no campo, do expropriado de outras favelas, no qual a presença de novas expropriações é constante e se apresenta pela urbanização de favelas que põe abaixo as casas e barracos para "melhorias" de circulação, e não reassenta essas famílias; pelos traficantes e milicianos que podem expropriar os moradores visando utilizar seus imóveis para a movimentação de comércio e atividades ilícitas; pelos possíveis projetos de regularização fundiária e os "custos" da cidadania e do urbano transformado em negócio; pelas novas atividades industriais que se realizam na periferia da metrópole carioca, etc.

Nas periferias a dimensão violenta da urbanização se explicita. A urbanização da sociedade expõe a situação permanentemente crítica que se conforma o modo de produção capitalista: destruição destrutiva, situação permanente de crise estrutural, mundialização do capital, produção de novas raridades e a conformação da impossibilidade do urbano para todos. Acreditamos que as periferias do extremo oeste realizam essa impossibilidade.

Percebeu-se, ainda, que há uma racionalidade econômica engendrando um planejamento submetido à mercadoria, que financeiriza o urbano e a pobreza, opacificando a 
produção do espaço da periferia e se atendo a uma miopia desses espaços, incluindo de forma precária e marginal $^{76}$ a classe trabalhadora.

Como desenvolvemos ao longo da dissertação, os processos excludentes se revelam como inserção precária na metrópole. O processo de reprodução do capital não coloca os sujeitos sociais para fora da sociedade, mas os incluem em fragmentos do espaço precários e periféricos. As condições que são estruturais da vida cotidiana são a crise e a situação crítica da realização da vida, contradições explícitas nas favelas da periferia do Rio de Janeiro, alvo de planejamento submetido à urbanização como negócio e a cidadania realizada através de pagamentos dos serviços. O econômico se descola do social de modo cada vez mais fetichizado. Compreendemos, então, finalmente, que a questão do abastecimento de água, particularmente na periferia das metrópoles capitalistas, é reveladora dessa crise estrutural do capital.

\footnotetext{
${ }^{76}$ José de Souza Martins (1997) propõe a categoria de inclusão marginal como um substituto conceitual do termo exclusão.
} 


\section{Referências Bibliográficas}

ABRAMO, P. Mercado de imóveis para uso comercial em favelas. Coleção Estudos Cariocas. Rio de Janeiro: IPP/PCRJ/IPPUR, 2003.

ABREU, M. de A. A evolução urbana do Rio de Janeiro. Rio de Janeiro: IPP, 2008.

ABREU, M. de A. Da habitação ao habitat: A questão da habitação popular no Rio de Janeiro e sua evolução. Revista Rio de Janeiro n. 10, p. 161-177, 2004.

ABREU, M. de A. Habitação popular, forma urbana e transição para o capitalismo industrial. In: BECKER, Bertha K. et al.. (Org.). Geografia e meio ambiente no Brasil. São Paulo e Rio de Janeiro: Hucitec/Comissão Nacional do Brasil da União Geográfica Internacional, 1995, p. 118-135.

ABREU, M. de A. O estudo geográfico da cidade no Brasil: Evolução e avaliação (Contribuição à história do pensamento geográfico brasileiro). In: CARLOS, Ana Fani A. (org.). Os caminhos da reflexão sobre a cidade e o urbano. São Paulo: Edusp, 1994, p. 199322.

ALENTEJANO, P. R. R. Chuvas e hipocrisia. São Gonçalo: UERJ/FFP, 2010. 2p. (mimeogr.) Disponível em: //agb-rio.wednote.com.br.

ALMEIDA, S. C. A.; SILVA, Édson R. P. da; NAVARRO, Leonardo L. L. Dimensionamento da produção de biogás a partir de resíduos residenciais, industriais e de matrizes suínas na comunidade Vila Paciência (RJ). In: XII CBE Congresso Brasileiro de Energia, 2008. Rio de Janeiro. XII Congresso Brasileiro de Energia, 2008.

ALTVATER, E. Existe um marxismo ecológico. In: ATILIO, A.; AMADEO, J.; GONZALEZ, S. A teoria marxista hoje. Problemas e perspectivas. 2007. Disponível em: $<$ http://bibliotecavirtual.clacso.org.ar/ar/libros/campus/marxispt/cap. 15.doc> Acessado em: 3 mai. 2011

ALTVATER, E. O preço da riqueza. São Paulo: Editora UNESP, 1995.

ALVAREZ, I. A. P. A proteção da natureza como condição da reprodução. São Paulo: Labur Edições, 2008 (Resenha de livro).

AMORIM, P. H. P. de O. Construindo objetos científicos: o caso da água na Geografia acadêmica brasileira. Geografia. Ensino \& Pesquisa, v. 12, p. 29-43, 2008.

ARANTES, A. O FMI e a Nova Dependência Brasileira. São Paulo: Alfa Omega, 2002.

ARANTES, O.; VAINER, C.; MARICATO, E. A cidade do pensamento único desmanchando consensos. Petrópolis: Vozes, 2007.

ARANTES, P. Zero à esquerda. São Paulo: Conrad, 2004.

ARANTES, P. Extinção. São Paulo: Boitempo, 2007.

ARANTES, P. F. A renda da forma na arquitetura da era financeira. In: OLIVEIRA, F. de. RIZEK, C.; BRAGA, R. (org.). Hegemonia às avessas. 1 ed. São Paulo: Boitempo, p. 161$184,2010$.

ARANTES, P. F. O Ajuste Urbano: as políticas do Banco Mundial e do BID para as cidades. São Paulo. Revista do Programa de Pós Graduação em Arquitetura e Urbanismo da FAU/USP, v. 20, p. 60-75, 2006.

ARRETCHE, M. Federalismo e Políticas Sociais no Brasil: problemas de coordenação e autonomia. São Paulo em Perspectiva, São Paulo, v. 18, n. 2, p. 17-26, 2004. 
ARRETCHE, M. Política Nacional de Saneamento: A Reestruturação das Companhias Estaduais. Brasília: IPEA - Instituto de Planejamento e Economia Aplicada, 1999.

ARRETCHE, M. Saneamento. Boletim de Conjuntura Política Social, São Paulo, n. 24, p. 46-50, 1998.

ASSOCIAÇÃO DOS EMPREGADOS DE NÍVEL UNIVERSITÁRIO DA CEDAE ASEAC. Oito anos de luta - Luta política marca a gestão incansável em defesa da CEDAE. Edição maio-junho, 2004, p. 7-9.

BAHIA, M. D. P. Política de Intervenção Urbana: uma leitura crítica sobre os Programas Rio Cidade e Favela Bairro. Rio de Janeiro: IPPUR-UFRJ, 2000. (Dissertação de Mestrado em Planejamento Urbano e Regional).

BALANYÁ, B.; BREnNAN, B.; KISHIMOTO, S. et. al. (orgs.) Por um modelo público de água: triunfos, lutas e sonhos. São Paulo: Casa Amarela, 2007.

BARbosA, F.; WAlCACER, F. C. Aspectos do Sistema de Abastecimento de Água do Estado do Rio de Janeiro - O Rio Guandu e a Gestão dos Recursos Hídricos. Rio de Janeiro: FGV, 2004.

BARBOSA, J. L.; SILVA, J. S. O que é favela, afinal? Rio de Janeiro: Observatório de Favelas / BNDES, v.1, p.100, 2009

BECKER, D. et al. Empowerment e avaliação participativa em um programa de desenvolvimento local e promoção da saúde. Ciência \& Saúde Coletiva, vol.9 n.3. p.655667,2004

BERNARDO, J. O inimigo oculto: ensaio sobre a luta de classes, manifesto antiecológico. Porto: Afrontamento, 1979.

BEZERRA, J. P. P. A água como elemento estruturante na construção de territórios da soberania alimentar. Presidente Prudente, Boletim NERA. NERA-Unesp, 2011.

BLANK, G. Brás de Pina: experiência de urbanização em favelas. In: VALLADARES, Licia do Prado (org.) Habitação em questão. Rio de Janeiro: Jorge Zahar, 1979.

BLAY, E. Crise urbana ou crise da reprodução do capital? In: (org.) A luta pelo espaço: textos de sociologia urbana. Petrópolis: Vozes, 1979.

BOITO JUNIOR, A. A burguesia no Governo Lula. Crítica Marxista (São Paulo), Rio de Janeiro, v. 21, p. 52-77, 2005.

BONDUKI, N.; ROLNIK, R. Periferias. São Paulo: FUPAM- FAUUSP, 1979.

BOTELHO, M. L.; BARREIRA, M. R. A. Crise urbana e favelização no Rio de Janeiro: para uma crítica da questão urbana contemporânea. In: III Simpósio Lutas Sociais na América Latina. Trabalhadore(a)s em movimento: constituição de um novo proletariado?, 2008, Londrina. Anais..., 2008 (mimeogr.)

BRITTO, A. L. N. P. Condições de acesso aos serviços de saneamento no Rio de janeiro: uma análise através da perspectiva da Justiça Ambiental. In: Luiz Cesar de Queiroz Ribeiro. (Org.). Metropóles: entre coesão e fragmentação, a cooperação e o conflito. São Paulo / Rio de Janeiro: Fundação Perseu Abramo / FASE, 2004.

BRITTO, A. L. N. P. Território e governo: possibilidades de novos arranjos institucionais e escalas espaciais na gestão do saneamento. In: Anais do XIII Encontro da Associação Nacional de Pós-Graduação e Pesquisa em Planejamento Urbano - Florianópolis - Santa Catarina: 25 a 29 de maio de 2009. 
BRITTO, A. L. N. P.; CARNEIRO, P.R.F. Gestão metropolitana e gerenciamento integrado dos recursos hídricos. Cadernos Metrópole (PUCSP), v. 22, p. 102-110, 2009.

BRITTO, A. L. N. P.; FORMIGA-JOHNSSON, R. M. Mudanças climáticas, saneamento básico e governança da água na Região Metropolitana do Rio de Janeiro. In: V Encontro Nacional da ANPPAS - Associação Nacional de Pós-Graduação e Pesquisa em Ambiente e Sociedade, Florianópolis, 2010.

BUENO, L. M. de M. Projeto e Favela: Metodologia de projeto em urbanização de favelas. 2000. 176f. Tese (Doutorado em Arquitetura e Urbanismo) - Faculdade de Arquitetura e Urbanismo, Universidade de São Paulo, São Paulo, 2000.

BURGOS, M. T. B. Dos Parques Proletários ao Favela Bairro: As Políticas Públicas nas Favelas do Rio de Janeiro. In: Alba Zaluar; Marcos Alvito. (Org.). Um Século de Favela. Rio de Janeiro: Fundação Getulio Vargas, p. 25-60, 2006

BURGOS, M.. T. B. O Muro e o Significado do Muro. Boletim Cedes, v. 4, p. 1-2, 2009.

CALABI, D.; INDOVINA, F. Sobre o uso capitalista do território. Revista Orientação, Depto de Geografia da FFLCH, USP, São Paulo, n. 9, 1992 (texto original de 1973).

CAPEL, H. El água como servicio público. In: Anais do Seminário Internacional "Faire Parler Les Reseaux: L'eau, Europe-Amérique Latine", Paris, jan. 2000. Disponível em: http://www.ub.es/geocrit/b3w-218.htm. Acesso em 2 jun. 2010

CARCANHOLO, M. Causa e Formas de Manifestação da Crise: uma interpretação do debate marxista. 1996. Dissertação (Mestrado) - Faculdade de Economia, Universidade Federal Fluminense, Niterói, 1996.

CARDOSO, A. L.; ARAUJO, R. L. A políitica de urbanização de favelas no Rio de Janeiro. In:.CARDOSO, Adauto L. (Org.) Habitação Social nas Metrópoles Brasileiras: uma avaliação das políticas habitacionais em Belém, Belo horizonte, Porto Alegre, Recife, Rio de Janeiro e São Paulo no final do século XX. Porto Alegre: ANTAC, 2007. p. 276-323

CARDOSO, A. L.; RIBEIRO, L. C. de Q. Plano Diretor e gestão democrática da cidade. In: (orgs.) Reforma Urbana e gestão democrática: promessas e desafios do estatuto da cidade. Rio de Janeiro: Revan/FASE, 2003.

CARDOSO, A. L.; RIBEIRO, L. C. Q. Planejamento urbano no Brasil: paradigmas e experiências. Revista Espaço e Debates, Ano XIV, n. 37, p. 77-89, 1994.

CARLOS, A. F. A. A "ilusão" da transparência do espaço e a "fé cega" no planejamento urbano: os desafios de uma geografia urbana crítica. Presidente Prudente, Cidades, v. 6, p. 289-306, 2009.

CARLOS, A. F. A. A cidade. São Paulo: Contexto, 2003.

CARLOS, A. F. A. A Mundialidade do Espaço. In: Ana Fani Alessandri Carlos. (Org.). O lugar no/do mundo. São Paulo: Hucitec, 1996, p. 121-134

CARLOS, A. F. A. A urbanização da sociedade: questões para o debate. In: OLIVEIRA, M. P.; COELHO, M. C. N.; CORRÊA, A. de M. (orgs.). O Brasil, a América Latina e o Mundo: espacialidades contemporâneas (II). Rio de Janeiro: Lamparina, v. 2, p. 49-60, 2008 .

CARNEIRO, M. L. F.; ÁVILA, R. V. de. A Dívida e as privatizações. 2007. Disponível em: www.divida-auditoriacidada.org.br. Acesso em $1^{\circ}$ de março de 2010. 
CASTRO, J. P. M. Da favela à comunidade: Formas de classificação e identificação de populações no Rio de Janeiro. Revista ANTHROPOLÓGICAS, ano 8, vol. 15 n.2, p. 171198, 2004.

CAVALCANTI, C. O que é Economia Ecológica: resgate de uma perspectiva. EcoEco. Boletim da Sociedade Brasileira de Economia Ecológica. n. 20, 2009.

CAVALLIERI, F. O efeito da presença governamental sobre a expansão horizontal das favelas do Rio de Janeiro: os Pouso's e o Programa Favela-Bairro. Coleção Estudos Cariocas. Rio de Janeiro: PCRJ/SMU/IPP, 2009.

CHESNAIS, F. A mundialização do capital. São Paulo: Xamã, 1998.

CHESNAIS, F. O Capital portador de juros: acumulação, internacionalização, efeitos econômicos e políticos. In: CHESNAIS, F. (org). A finança mundializada. São Paulo: Xamã, 2005.

CHESNAIS, F. Orígenes comunes de la crisis económica y la crisis ecológica. Herramienta, n.41, 2009. Disponível em: <http://www.herramienta.com.ar/revista-impresa/revistaherramienta-n-41> Acesso em 25 set. 2010

CHESNAIS, F.; SERFATI, C. "Ecologia" e condições físicas de reprodução social: alguns fios condutores marxistas. São Paulo. Crítica Marxista, n. 16, p. 39-75, 2003.

CLARKE, R.; KING, J. O Atlas da água. São Paulo: Publifolha, 2006.

COSTA, V. G. Análise preliminar dos indicadores utilizados para caracterização dos setores de baixa renda . Rio de Janeiro: IBGE, Departamento de Geografia, 2001.

COSTA, V. G. Em busca da redefinição de favelas e assemelhados: O Projeto caracterização dos setores de baixa renda (proposta preliminar). Rio de Janeiro: IBGE, Departamento de Geografia, 2002b.

COSTA, V. G. O conceito de favelas e assemelhados, críticas, o estado da arte e novas possibilidades. Trabalho apresentado em reunião técnica realizada na presidência do IBGE. Rio de Janeiro: IBGE, Departamento de Geografia, 2002a.

CUSTÓDIO, V. A apropriação dos recursos hídricos e o abastecimento de água na Região Metropolitana de São Paulo. São Paulo: FFLCH/USP, 1994 (Dissertação de mestrado em Geografia Humana).

CUSTÓDIO, V. A relação cidade-água nos artigos dos Anais da Associação dos Geógrafos Brasileiros. Geousp, v. 20, p. 175-182, 2006.

CUSTÓDIO, V. A retomada do planejamento federal e as políticas públicas no ordenamento do território municipal: a temática das águas e do saneamento. Revista do Departamento de Geografia (USP). v.16, p.95 - 104, 2005.

CUSTODIO, V. O abastecimento de água: das bicas à Sabesp In: São Paulo: metrópole em mosaico (Série Nossa História 3). São Paulo: Centro de Integração Empresa-Escola - CIEE, v.3, p. 209-225, 2010

DAGDEVIREN, H.; ROBERTSON, S. A., Access to Water in the Slums of the Developing World. Working Papers, n. 57, International Policy Centre for Inclusive Growth, 2009.

DAMIANI, A. L. A urbanização crítica na metrópole de São Paulo a partir de fundamentos da Geografia Urbana. Revista da ANPEGE, v. 5, p. 51 - 70, 2009.

DAMIANI, A. L. Meio Ambiente: Privatização da Natureza em Cubatão. Boletim Paulista de Geografia, São Paulo, v. 62, p. 47-66, 1986. 
DAMIANI, A. L. O urbano no mundo da mercadoria. In. CARLOS, A. F. A. e LEMOS, A. I.G. Dilemas urbanos: novas abordagens sobre a cidade. São Paulo: Contexto, 2003.

DAMIANI, A. L. Urbanização crítica: periferias urbanas, In: CAMARGO, Ana Maria de A (coord.). São Paulo - Metrópole em Mosaico. Série Nossa História III. São Paulo: CIEE Centro Integrado Empresa Escola, 2010.

DAVIDOVICH, F. Um repensar da favela: tendências e questões. Cadernos Metrópoles, n. 4, p. 118-133, 2000

DAVIS, M. A cidade de quartzo. São Paulo: Boitempo, 2009.

DEBORD, Guy. A Sociedade do Espetáculo. Rio de Janeiro, Contraponto, 1997.

ECHEVENGUÁ, A. C. O sistema pré-pago de abastecimento d'água e a geração dos "sem água". Revista Jus Vigilantibus. Disponível em: <http://jusvi.com/artigos/893> Acesso em: 5 jan. 2010.

ENGELS, F. A Origem da Família, da Propriedade Privada e do Estado. Rio de Janeiro: Bertrand Brasil, 1995. Trad.: de Leandro Konder.

ESCOBAR, A. La invención del Tercer Mundo. Construcción y deconstrucción del desarrollo. Bogotá: Editorial Norma, 1998.

FARIA, T. C. de A. Favelas na periferia: (re) produção ou mudança nas formas de produção e acesso à terra e moradia pelos pobres na cidade do Rio de Janeiro nos anos 90? 2004. 188p. Tese (Doutorado em Planejamento Urbano e Regional) - Instituto de Pesquisa e Planejamento Urbano, Universidade Federal do Rio de Janeiro, 2004.

FARIAS, L. A. C. A Zona Oeste da cidade do Rio de Janeiro: uma visão intra-urbana das desigualdades. 2009. (Monografia em Geografia) - Instituto de Geociências, Universidade Federal do Rio de Janeiro, Rio de Janeiro, 2009.

FELIPPE, M. F. A Geografia do ciclo hidrossocial: uma abordagem crítica. 2010. Disponível em: <http://www.gsf.org.br/?q=node/77> Acesso em: 20 mar. 2011

FERNANDES, F. L. Violência, medo e estigma: Efeitos sócio-espaciais da "atualização" do "mito da marginalidade". 2009. Tese (Doutorado em Geografia) - Instituto de Geociências, Universidade Federal do Rio de Janeiro, Rio de Janeiro, 2009.

FERNANDES, F. L.; SILVA, J. S.; BRAGA, R. W. Grupos criminosos armados com domínio de território. Reflexões sobre a territorialidade do crime na Região Metropolitana do Rio de Janeiro. Segurança, tráfico e milícias no Rio de Janeiro. Rio de Janeiro: Justiça Global/Fundação Heinrich Böll, 2008, p. 16-24.

FERNANDES, N.N. O rapto ideológico da categoria subúrbio: Rio de Janeiro 1858/1945. 1996. Dissertação (Mestrado em Geografia) - Instituto de Geociências, Universidade Federal do Rio de Janeiro, Rio de Janeiro, 1996.

FERREIRA, A. Favelas no Rio de Janeiro: nascimento, expansão, remoção e, agora, exclusão através de muros. Biblio 3W, Revista Bibliográfica de Geografía y Ciencias Sociales. Universidad de Barcelona, vol. XIV, n. 828, 25 de junio de 2009. <http://www.ub.es/geocrit/b3w-828.htm>. Acesso em 29 mai. 2010

FERREIRA, J. S. W. Cidades para poucos ou para todos? Impasses da democratização das ciudades no Brasil e os riscos de um "urbanismo às avessas". In: OLIVEIRA, F. de. RIZEK, C.; BRAGA, R. (org.). Hegemonia às avessas. 1 ed. São Paulo: Boitempo, p. 185-214, 2010. 
FONTENELLE, I. Fetiche do eu autônomo: consumo responsável, excesso e redenção como mercadoria. Psicologia e sociedade. v. 22. 2010 (mimeogr.).

FONTES, V. Imperialismo e crise. In: SAMPAIO JR., P. de A. Capitalismo em crise: a natureza e dinâmica da crise mundial. São Paulo: Instituto José Luis e Rosa Sundermann, 2009.

FOSTER, J. B. A ecologia de Marx. Rio de Janeiro: Civilização brasileira, 2005.

FREIRE, A.; OLIVEIRA, L. L. (org.) Capítulos da memória do urbanismo. Rio de Janeiro: FGV, 2002.

FREITAS, E. A reprodução social da metrópole em Belo Horizonte: APA Sul RMBH, mapeando novas raridades. 2004. 278f. Dissertação (Mestrado) - Instituto de Geociência, Universidade Federal de Minas Gerais, Belo Horizonte, 2004.

FRIDMAN, F. Os donos da terra carioca - alguns estudos de caso. Espaço e Debates, n. 37, p. 10-18, 1994.

GILLY, A.; ROUX, R. Capitales, tecnologías y mundos de la vida. El despojo de los cuatro elementos. Herramienta, n. 40, 2009. Disponível em: $<$ http://www.herramienta.com.ar/revista-herramienta-n-40/capitales-tecnologias-y-mundosde-la-vida-el-despojo-de-los-cuatro-elemento>. Acesso em: 2 de dez. de 2010.

GOELLNER, C. Uso, consumo, cobrança e titularidade da água no Brasil. Passo Fundo: UPF, 2008.

GOMES, G. F. Direto fundamental à água e a Constituição de 1988. In: XIX Encontro Nacional do CONPEDI, Fortaleza, 2010.

GRESPAN, J. L. S. A desmedida da crise. Discurso. Departamento de Filosofia da FFLCH da USP, São Paulo, v. 27, p. 117-139, 1996.

GRESPAN, J. L. S. Anotações de aula: Estudo sobre o materialismo histórico. jul. à dez. 2010

GRESPAN, J. L. S. O negativo do capital. São Paulo: Hucitec, 1996.

HAM, C. e HILL, M. O processo de elaboração de políticas no Estado capitalista moderno. Campinas: IFCH, 1993 (mimeogr.)

HARVEY, D. O "novo" imperialismo: sobre rearranjos espaço-temporais e acumulação mediante despossessão. Margem Esquerda - ensaios marxistas, n. 5, São Paulo, Boitempo Editorial, maio de 2005.

HARVEY, D. O Novo Imperialismo. São Paulo: Loyola, 2005.

HENKES, S. L., Histórico legal e institucional dos recursos hídricos no Brasil. Teresina. Jus Navigandi, 2003.

IORIS, A. A. R. Água, cobrança e commodity: a Geografia dos Recursos Hídricos. Terra Livre, n. 25, v. 2, ano 21. 2005. p. 121-137.

KEHL, M. R. Televisão e violência do imaginário. In: BUCCI, E. KEHL, M. R. Videologias - ensaios sobre a televisão. São Paulo: Boitempo, 2004.

KLEIMAN, M. Análise qualitativa dos Programas "Favela-Bairro", Despoluição da Baía de Guanabara e Nova Baixada. Rio de Janeiro, IPPUR/UFRJ, 2003.

KLEIMAN, M. Constituição de uma Metodologia de Avaliação do Impacto das Redes de Infra-estrutura no Âmbito do Programa "Favela-Bairro" através da Construção de 
Indicadores Qualitativos. Rio de Janeiro: Relatório de Pesquisa, FINEP - Prefeitura do Rio de Janeiro, 1996.

KLEIMAN, M. Permanências e mudanças no padrão de alocação socioespacial das redes de infra-estrutura no Rio de Janeiro. Cadernos IPPUR. Ano XV, n. 2, ago-dez 2001/Ano XVI, n. 1, jan-jul 2002. p. 123-154

KOWARICK, L. A espoliação urbana. Rio de Janeiro: Paz e Terra, 1983.

LACOMBE, M. S. M. De Pasárgada à Quinta Lebrão: o direito dos excluídos. Teresópolis. Cadernos do curso de Direito, v. 1, p. 1-33, 2003.

LAGO, L. C. do (org.) Como Anda o Rio de Janeiro. Rio de Janeiro: Letra Capital Editora, 2009. v. 1.73 p.

LAGO, L. C. do. O direito à moradia nos limites da lei. In: RIBEIRO, A. C. T.; PIQUET, R. (org.). Brasil, território da desigualdade. Rio de Janeiro: Jorge Zahar/FUJB, 1991.

LAGO, L. C. do. O movimento de loteadores no Rio de Janeiro. Rio de Janeiro: IPPUR/UFRJ, 1990. (Dissertação de mestrado em Planejamento Urbano e Regional)

LAGO, L. C. do.; RIBEIRO, L. C. Q. A divisão favela-bairro no espaço social do Rio de Janeiro. Cadernos Metrópoles, nº 5, p. 29-46, 2001.

LAGO, L. C. Favela-loteamento: reconceituando os termos da ilegalidade e da segregação urbana. Cadernos Metrópole (PUCSP), São Paulo, v. 9, n. 1, p. 119-133, 2003.

LEFEBVRE, H. A revolução urbana. Belo Horizonte: Editora UFMG, 2008a.

LEFEBVRE, H. A vida cotidiana no mundo moderno. São Paulo: Ática, 1981.

LEFEBVRE, H. Espaço e política. Belo Horizonte: Editora UFMG, 2008 b.

LEFEBVRE, H. Marxismo. Porto Alegre: L\&PM, 2009.

LEFEBVRE, H. O direito à cidade. São Paulo: Centauro, 2001.

LEITÃO, G. Dos barracos de madeira aos prédios de quitinetes: uma análise do processo de produção da moradia na favela da Rocinha, ao longo de cinqüenta anos. Niterói, EdUFF, 2009.

LIMA, G. T. Naturalizando o Capital, Capitalizando a Natureza: O Conceito de Capital Natural no Desenvolvimento Sustentável. In: NOBRE, M.; AMAZONAS, M. de C. (Org.). Desenvolvimento Sustentável: A Institucionalização de um Conceito. 1 ed. Brasília: Edições Ibama, v. 1, p. 343-367, 2002.

LOPES, N. R. M. Coronelismo e Chaguismo na Zona Oeste do Rio de Janeiro: clientelismo ou o coronel e o caso das bicas d'água no Mendanha. 2007. 106f. Dissertação (Mestrado em Políticas Públicas e Formação Humana) - Centro de Educação e Humanidades, Universidade Estadual do Rio de Janeiro, Rio de Janeiro, 2007.

MACHADO DA SILVA, L. A. Afinal, qual é a das UPPs? Boletim do Observatório das Metrópoles, Rio de Janeiro, 18 mar. 2010

MACHADO, T. R. Cidade e meio ambiente em debate: notas sobre o papel da infra-estrutura de saneamento no planejamento estratégico urbano. Revista Discente Expressões Geográficas. Florianópolis, n. 03, p. 42-59, Maio de 2007.

MACHADO, T. R. Para uma cidade maravilhosa um plano maravilha: uma leitura critica sobre a produção da imagem turistica e marketing urbano no Rio de Janeiro. Rio de Janeiro: UFRJ, 2004. (Dissertação de mestrado em Planejamento Urbano e Regional). 
MAIA, C. O Rio de Janeiro e o Favela Bairro. Coleção Estudos Cariocas. Rio de Janeiro: PCRJ/SMU/IPP, 2003.

MAIA, R. Entre a majestade e o caos: história, cultura e cotidiano de uma área periférica da cidade do Rio de Janeiro Revista Mercator, v. 7, p. 13, 2008.

MAIA, R. Fala, periferia! Mostra a tua cara. In: XIII Congresso Brasileiro de Sociologia, 2007, Recife. Anais do XIII Congresso Brasileiro de Sociologia. Recife, p. 1-17, 2007.

MAMARI, F. G. C. de. Se morar é um direito, ocupar é um dever! As ocupações de Semteto na Metrópole do Rio de Janeiro. Rio de Janeiro: UFRJ, 2008.

MAMEDE, A. C. Conjunto Habitacional Antares e Favela de Dona Marta: Associações de Moradores e suas relações com o tráfico de drogas e o Primeiro Governo Brizola no Estado do Rio de Janeiro (1983-1987). 2005. Dissertação (Mestrado em História Comparada) - Instituto de Filosofia e Ciências Sociais, Universidade Federal do Rio de Janeiro. Rio de Janeiro, 2005.

MANKIW, N.G. Introdução à Economia. São Paulo: Pioneira Thomson Learning, 2005.

MARQUES, E. C. L. Da higiene à construção da cidade: a constituição do setor saneamento no Rio de Janeiro. Revista História, Ciências, Saúde-Manguinhos, v. 2, n. 2, 1995.

MARQUES, E. C. L. Desigualdades sociais e infra-estrutura urbana: a produção dos equipamentos de saneamento no Rio de Janeiro. Rio de Janeiro: IPPUR/UFRJ, 1993. (Dissertação em Mestrado em Planejamento Urbano e Regional).

MARQUES, E. C. L. Estado e redes sociais: permeabilidade e coesão nas políticas urbanas no Rio de Janeiro. Rio de Janeiro: Revan; São Paulo: FAPESP, 2000.

MARQUES, E. C. L. Infra-estrutura urbana e produção do espaço metropolitano do Rio de Janeiro. Cadernos IPPUR/UFRJ, Rio de Janeiro, v. XII, n. 2, 1998

MARQUES, E. C. L. Notas críticas a literatura sobre Estado, políticas estatais e atores políticos. In: BIB: Boletim Bibliográfico de Ciências Sociais, n. 43, p. 67-102, 1997.

MARQUES, E. C. L.; TORRES, H. São Paulo: segregação, pobreza urbana e desigualdade social. São Paulo: Ed. Senac, 2005.

MARTINS, A. L. M. Aportes teóricos marxistas à questão da educação ambiental. In: Colóquio Marx Engels, VI. 2009, Campinas. Anais..., Campinas: Cemarx - Unicamp, 2009.

MARTINS, J. de S. A Sociedade Vista do Abismo: Novos estudos sobre exclusão, pobreza e classes sociais. Petrópolis: Vozes, 2002.

MARTINS, J. de S. O cativeiro da terra. 9 ed. São Paulo: Contexto, 2010.

MARTINS, J. de S. Subúrbio (Vida cotidiana e História no subúrbio de São Paulo). São Paulo: Editora Hucitec, 1992.

MARX, K. Crítica da filosofia do direito de Hegel. São Paulo: Boitempo Editorial, 2005 [1843]. Trad.: Rubens Enderle e Leonardo de Deus.

MARX, K. Formações Econômicas Pré-Capitalistas. São Paulo: Paz e Terra, $7^{\text {a }}$ ed. 2006.

MARX, K. Introdução para a Crítica da Economia Política - Coleção Os Pensadores. São Paulo: Abril Cultural, 1974.

MARX, K. Manuscritos econômicos-filosóficos e outros textos escolhidos. Seleção de textos: José Arthur Giannotti; tradução: José Carlos Bruni. São Paulo: Nova Cultural, 1987. 
MARX, K. O capital - crítica da Economia Política. Livro I. São Paulo: Abril Cultural, 1985. Trad. Regis Barbosa e Flávio R. Kothe

MARX, K. O capital - crítica da Economia Política. Livro III. São Paulo: Abril Cultural, 1986. Trad. Regis Barbosa e Flávio R. Kothe

MARX, K. Prefácio à Contribuição à Crítica da Economia Política. In: FERNANDES, Florestan (org.). K. Marx, F. Engels: História. São Paulo: Ática, 1984.

MATOS, O. C. F. Imaginação e feitiço: metamorfoses da ilusão. Discurso. Departamento de Filosofia da FFLCH da USP, São Paulo, n. 29, p. 230-250, 1998.

MATOS, O. C. F. O mal-estar na contemporaneidade: performance e tempo. In: MEDEIROS, B.; MONTEIRO, M.; MATSUMOTO, R. Tempo e performance. Brasília: Editora da Universidade de Brasília, 2007.

MATTOS, C. P. de. A produção do espaço em Rio das Ostras. 2009. Dissertação (Mestrado) - Instituto de Geociências, Universidade Federal Fluminense, Niterói, 2009.

MEERGANZ VON MEDEAZZA, G. Flujos de agua, flujos de poder. La aportación de Erik Swyngedouw al debate sobre los reursos hídricos en Lationoamerica y en el Estado español. Documents d'Anàlisi Geogràfica. Barcelona, n. 47, p. 129-139, 2066.

MELO, M. A. B. C. de. O padrão brasileiro de intervenção pública no saneamento básico. In: Revista Brasileira de Administração Pública v.23, p.15-38. Rio de Janeiro, FGV, 1989.

MENEGAT, E. A periferia é o limite: notas sobre a crise do modelo ocidental de urbanização. Cadernos Metrópole (PUCSP) v. 13, p. 107-132, 2005.

MENEGAT, E. Crise urbana na atualidade: indagações a partir do fenômeno da concentração espacial dos pobres em assentamentos ilegais. Le monde diplomatique Brasil v. 2, p. 20-27, 2009

MENEGAT, E. Limites do Ocidente: um roteiro para estudo da crise de formas e conteúdos urbanos. 2003. Tese (Doutorado) - Instituto de Pesquisa e Planejamento Urbano e Regional, Universidade Federal do Rio de Janeiro, Rio de Janeiro, 2003.

MÉSZÁROS, I. A crise estrutural do capital. São Paulo: Boitempo, 2009.

MÈSZÀROS, I. O desafio e o fardo do tempo histórico. São Paulo: Boitempo, 2002

MÈSZÀROS, I. Para além do capital. São Paulo: Boitempo, 2007.

MISSE, M. El delito como parte del mercado ilegal: violencia, mercancía política y narcotráfico en Rio de Janeiro. In: STANLEY, R. (org.). Estado, violencia y ciudadanía en América Latina. Madrid: Entimema, p. 109-127, 2009

MONDEGO, D. O problema da escassez hídrica. Rio de Janeiro: ASEAC, 2002 (mimograf.)

MONDEGO, D. O problema hídrico no mundo - "o Brasil e a Amazônia", Rio de Janeiro, Palestra proferida no Centro Brasileiro de Estudos Estratégicos (Cebres), no dia 15 de julho de 1997 (mimeogr.)

MOREIRA, R. Geografia. $2^{a}$ edição revista e atualizada. Niterói: Instituto de GeociênciasUFF, 2009. (mimeograf.)

MOREIRA, R. Marxismo e geografia. GEOgraphia. Ano 6, n. 11, p. 21-37, 2004.

MOREIRA, R. Para onde vai o pensamento geográfico?: Por uma epistemologia crítica. São Paulo: Contexto, 2006. 
MOTA, M. S. C. Nas terras de Guaratiba: uma aproximação histórico-jurídica às definições de posse e propriedade da terra no Brasil entre os séculos XVI - XIX. 2009. 340f. Tese (Doutorado em Ciências Sociais) - Curso de Pós-Graduação em Desenvolvimento, Agricultura e Sociedade, Universidade Federal Rural do Rio de Janeiro, Seropédica, 2009.

MOTA, M. S.; LOPES, NELSON, R. M. Milícias e segregação sócio-territorial na zona oeste do município do Rio de Janeiro. In: Encuentro de Geógrafos de América Latina,XII. 2009, Montevideo. Caminando en una América Latina en transformación. Anais...Montevideo: Imprenta Gega, v. 1. p. 63-63, 2009.

MOVIMENTO DE ATINGIDOS POR BARRAGEM (MAB). A luta dos atingidos por barragens contra as transnacionais, pelos direitos e por soberania energética. São Paulo: MAB, 2006.

NAKAMURA, D. O inimigo ainda é o mesmo. Notas sobre a articulação entre o capital financeiro e a violência nas favelas cariocas. Mimeo. 2011.

NAKAMURA, E. Crítica à lei da apropriação capitalista - a acumulação do capital e a sua zona de anomia. Dissertação (Mestrado em Filosofia) - Instituto de Ciências Humanas e Filosofia, Universidade Estadual de Campinas, Campinas, 2010.

NORONHA, L. C. Com boa gestão não faltará água. Porto Alegre: CORSAN, 2003.

NUNES, J. Ano 2010: panorama da política governamental para as favelas cariocas. In: XVI Semana de Planejamento Urbano e Regional - Rio de Janeiro: um território em disputa. Rio de Janeiro. Anais da XVI Semana PUR - Rio de Janeiro, 2010.

OLIVEIRA, A. M. et al. Favelas e Organizações Comunitárias. Petrópolis: Vozes, 1993.

OLIVEIRA, A. U. A Lógica da Especulação Imobiliária. São Paulo. Boletim Paulista de Geografia, n. 58, 1978.

OLIVEIRA, A. U. de. Agricultura e Indústria no Brasil. Campo-Território: Revista de Geografia Agrária, v.5, n.10, p. 5-64, 2010.

OLIVEIRA, A. U. de. Geografia Agrária: perspectivas no inicio do século XXI. In: ; MARQUES, Marta I.M. O campo no século XXI - território de vida,

de luta e de construção de justiça social. São Paulo: Casa Amarela, 2003.

OLIVEIRA, C. F. de. A gestão dos serviços de saneamento básico no Brasil. In: Anais do

Coloquio Internacional de Geocrítica. Santiago del Chile. Instituto de Geografía da Pontifícia Universidad Católica de Chile, p. 1-9, maio 2002.

OLIVEIRA, F. de. Globalização. A mercadoria. (texto entregue como síntese de aula). São Paulo: Programa de Pós-Graduação em Sociologia: 2010.

OLIVEIRA, F. de. O Estado e a exceção: ou o Estado de exceção? Revista Brasileira de Estudos Urbanos e Regionais, Belo Horizonte, v. 5, n. 1, p. 9-14, 2003.

OLIVEIRA, F. de. O Estado e o Urbano. Espaco \& Debates, São Paulo, v. 6, 1982.

PAIVA, A. P. P. O caminho da água no mundo e os impactos da intervenção humana. Belo Horizonte: Centro de Referência do Professor, 2009.

PAIXÃO, Y. N. F. Os problemas da gestão da bacia hidrográfica do rio Paraíba do Sul e suas consequências ambientais. In: Simpósio Brasileiro de Geografia Física Aplicada, XIII. 2009, Viçosa. Anais... Viçosa: UFV, 2009. 
PAULA, C. M. de. Degradação e Educação Ambiental em questão: reflexões a partir de uma experiência de campo no X Eregeo-SE. AGB - Informa. São Paulo, AGB - Seção São Paulo, 2007.

PAULANI, L. Brasil Delivery: servidão financeira e estado de emergência econômico. São Paulo: Boitempo, 2008.

PAUlANI, L. M. A Atualidade da Crítica da Economia Política. Critica Marxista (Roma), São Paulo, v. 10, p. 98-109, 2000.

PAULANI, L. M. Autonomização das formas sociais e crise. São Paulo. Crítica Marxista, v. 28, p. 37, 2009.

PENNA, N. A. Urbanização, Cidade e Meio Ambiente. Geousp, São Paulo, v. 12, n. 1, p. 34$51,2002$.

PEREIRA, J. S. 1996. Análise de critérios de outorga e cobrança pelo uso da água na bacia do rio dos Sinos, RS. 2003. 110f. (Mestrado em Engenharia Civil) - Curso de PósGraduação em Recursos Hídricos e Saneamento, Universidade Federal do Rio Grande do Sul, Porto Alegre, 1996.

PEREIRA, L. A. de S. O Programa Favela Bairro: dois estudos de caso. Dissertação (Mestrado) - Instituto de Geociências, Universidade Federal Fluminense, Niterói, 2008

PERLMAN, J. E. O mito da marginalidade - Favelas e política no Rio de Janeiro. Rio de Janeiro: Paz e Terra, 1979.

PETRAS, J. Hegemonia dos Estados Unidos no novo milênio. Petrópolis: Vozes, 2001.

PETRELLA, R. A água. O desafio do bem comum. In: NEUTZLING, Inácio (org). Água: bem público universal. São Leopoldo: Unisinos, p. 9-32, 2004a.

PETRElla, R. A nova “conquista da água”. Le Monde Diplomatique Brasil, 2000. Disponível em: <http://diplomatique.uol.com.br/acervo.php?id=57\&tipo=acervo\&PHPSESSID=726ce1 cea7e c25bc237a594352cb438c> Acesso em: 15 abr. 2011

PETRELLA, R. O manifesto da água: argumentos para um contrato mundial. Petrópolis: Vozes, 2004b.

PFEIFFER, C. R. Identificação dos motivos/razões utilizados pelas empresas para justificar suas atuações. In: Por que as empresas privadas investem em projetos sociais e urbanos no Rio de Janeiro? Rio de Janeiro: Ágora da Ilha, p. 21-25, 2001.

PIQUET, R. Modernização a qualquer preço. Cadernos IPPUR/UFRJ, Rio de Janeiro, p. 921, 1991.

PIRES DO RIO, G. A.; SALES, A. V. de S. Os serviços de água e esgoto no estado do Rio de Janeiro: regulação e privatização GEOgraphia. Ano 6, n. 11, p. 67-86, 2004.

PIRES, V. Fetichismo na teoria marxista: um comentário. Impulso (Piracicaba), Piracicaba, v. 10, n. 22-23, p. 59-66, 1998.

POGREBINSCHI, T. O enigma do político: Marx contra a política moderna. Rio de Janeiro: Civilização Brasileira, 2009.

PORTO-GONÇALVES, C. W. A globalização da natureza e a natureza da globalização. Rio de Janeiro: Civilização Brasileira, 2006. 
PORTO-GONÇALVES, C. W. A Luta pela Apropriação e Reapropriação Social da Água na América Latina. In: FERNANDES, B. M. (org.) Campesinato e agronegócio na América Latina: a questão agrária atual. São Paulo: Expressão Popular, 2008.

PORTO, M. Os caminhos da governança: avanços e dificuldades. Palestra proferida no II Encontro Internacional de Governança da Água: experiências na América Latina e Europa no Instituto Oceanográfico - USP no dia 23 de outubro de 2009.

PRIETO, G.F.T.; VERDI, E. F. A manutenção constitucional da barbárie: uma contribuição a análise da MP 458. In: Simpósio Nacional de Geografia Agrária, V; Simpósio Internacional de Geografia Agrária, IV. 2009, Niterói. Anais... Niterói/São Gonçalo: UFF/UERJ - FFP, 2009.

QUAINI, M. Marxismo e Geografia, Rio de Janeiro: Paz e Terra, 2002.

RANDOLPH, R. Arenas políticas e agenciamentos governamentais: uma discussão de novos formatos a partir da experiência do Programa Favela-Bairro e do Plano Estratégico da Cidade do Rio de Janeiro. In: Ana Clara Torres Ribeiro. (Org.). El rostro urbano de América Latina / O rosto urbano da América Latina. Buenos Aires: Consejo Latinoamericano de Ciencias Sociales - CLACSO, 2004, p. 273-300.

RANDOLPH, R. Determinações estratégicas e potencialidades de transformação do Programa Favela-Bairro. GEOgraphia (UFF) Niterói, v. 3, n. 5, p. 32-48, 2001.

REBOUÇAS, A.C. Água doce no mundo e no Brasil. In: REBOUÇAS, A.C.; BRAGA, B.; TUNDISI, J.G. Águas doces no Brasil: capital ecológico, uso e conservação. São Paulo: Escrituras, p. 1-37, 2002

RESENDE, V. Cidade História e Desafios. Rio de Janeiro: FGV, 2002

REVERS, I.; MALVEZZI, R. As perspectivas do uso da água e dos solos no Brasil - o futuro do agro e hidronegócio. Goiânia: Comissão Pastoral da Terra, 2009.

REZENDE, S.; HELlER, L. O saneamento no Brasil. Políticas e interfaces. Belo Horizonte: UFMG, 2008.

RIBEIRO, A. C. T. Cidade e capitalismo periférico: em direção à experiência popular. Margem Esquerda, v. 12, p. 25-31, 2008.

RIBEIRO, A. C. T. Reforma urbana nos limites da modernização. Espaço \& Debates, n. 37 , p. 100-106, 1994.

RIBEIRO, L. C. Q.; LAGO, L. C. Dinâmica urbana e novos padrões de desigualdade social. São Paulo em Perspectiva. São Paulo, v. 9, n. 2, p. 25-32, 1995.

RIZEK, C. Verde, amarelo, azul e branco: o fetiche de uma mercadoria ou seu segredo. . In: OLIVEIRA, F. de. RIZEK, C.; BRAGA, R. (org.). Hegemonia às avessas. 1 ed. São Paulo: Boitempo, p. 215- 233, 2010.

ROCHA, Amara. A sedução da luz: o imaginário da eletrificação no Rio de Janeiro (1892-1914) Rio de Janeiro: IFCS/UFRJ, 1996. (Dissertação de Mestrado em História Social).

ROCHA, A. P. Estudo de fenômenos vinculados ao tráfico de drogas: caminhos metodológicos percorridos por pesquisadores. Porto Alegre. Textos \& Contextos, v. 9, p. 103-117, 2010.

RODRIGUES, A. M. Problemática Ambiental = Agenda Política - Espaço, território, classes sociais. Boletim Paulista de Geografia - "Perspectiva Crítica" - AGB-SP. n. 83, p.91 a $110,2005$. 
SALVIATTI, A. P. A lógica capitalista e políticas internacionais de recursos naturais: uma análise histórica das medidas adotadas frente ao esgotamento ambiental. Da elaboração à ratificação do Protocolo de Kyoto das Nações Unidas. 2003. Monografia Faculdade de Filosofia, Letras e Ciências Humanas, Universidade de São Paulo, 2010.

SÁNCHEZ, F. Políticas urbanas em renovação: uma leitura crítica dos modelos emergentes. Revista Brasileira de Estudos Urbanos e Regionais, Campinas, v. 1, p. 115-132, 1999.

SANCHEZ, O. A. Privatização e Saneamento Básico. Perspectiva (Erexim), São Paulo, v. 15 , n. No 1 , p. 89-101, 2001

SANTANA, J. P. M. A apropriação mercadológica da natureza no espaço urbano da cidade do Rio de Janeiro: algumas considerações. Rio de Janeiro: Departamento de Geografia - PUC - Rio, 2006.

SANTANA, P. V. de. A mercadoria verde: a natureza. In: SEABRA, O. L. C; DAMIANI, A. L; CARLOS, A. F. A. (Org.). O Espaço no fim do Século: A nova Raridade. São Paulo: Contexto, p. 177-189, 1999.

SANTOS Jr., O. A. dos. Prefácio. In: Por Um Modelo Público de Água: triunfos, lutas e sonhos. São Paulo: Casa Amarela, 2007.

SANTOS, C. N. F. dos Movimentos urbanos no Rio de Janeiro. Rio de Janeiro: J. Zahar, 1981.

SANTOS, L. S.; FERNANDES, J. L. O querer vender quer dizer: urbanização e conflitos de terra através dos classificados imobiliários do Sertão Carioca (1927-1964). Revista IDEAS, v. 1, p. 62-74, 2007.

SANTOS, M. A urbanização brasileira. São Paulo: Hucitec, 1993

SANTOS, M. O espaço do cidadão. São Paulo: EDUSP, 2007

SANTOS, M. Sociedade e espaço: a formação social como categoria e como método Boletim Paulista de Geografia, n. 54. São Paulo, p. 81-100, 1977

SEABRA, O. C. de L. Embates entre questões ambientais e sociais no urbano. In: LEMOS, A. I. G.; CARLOS, A. F. A. (org.). Dilemas Urbanos: novas abordagens sobre a cidade. São Paulo: Contexto, 2003.

SEABRA, O. C. de L. Os Meandros dos rios nos meandros do poder: Tietê e Pinheiros Valorização dos rios e das várzeas na cidade de São Paulo. 1987. Tese (Doutorado) Faculdade de Filosofia, Letras e Ciências Humanas, Universidade de São Paulo, 1987.

SEABRA, O. C. de L. Territórios do Uso: Cotidiano e Modo de vida. Cidades (Presidente Prudente), v.1, p. 181-206, 2004.

SHIVA, V. Guerras por água: privatização, poluição e lucro. São Paulo: Radical Livros, 2006.

SILVA JÚNIOR, L. R. C. O Programa Favela-Bairro e as políticas habitacionais do Banco Interamericano de Desenvolvimento. 2006. Dissertação (Mestrado) - Instituto de Pesquisa e Planejamento Urbano e Regional, Universidade Federal do Rio de Janeiro. Rio de Janeiro, 2006.

SILVA, J. S. Adeus à cidade partida. Observatório das Favelas: Rio de Janeiro, 2003

SILVA, L. O. Terras Devolutas e Latifúndio - Efeitos da Lei de 1850. Campinas: Editora da Unicamp, 2008. 
SILVA, M. M. A participação da sociedade civil em diferentes modelos de prestação dos serviços públicos de abastecimento de água e esgotamento sanitário: estudo em quatro municípios no Brasil. 2010. Dissertação (Mestrado) - Escola Politécnica, Universidade Federal da Bahia, Salvador, 2010.

SILVEIRA, S. J. C. Externalidades negativas: as abordagens neoclássica e institucionalistas. Curitiba, Revista FAE, v.9, n.2, p.39-49, 2006

SMITH, N. Desenvolvimento desigual: natureza, capital e a produção do espaço. Rio de Janeiro: Bertrand Brasil, 1988.

SMOLKA, M. O. Expulsando os pobres e redistribuindo os ricos: "dinâmica imobiliária" e segregação residencial na cidade do Rio de Janeiro. Revista Brasileira de Estudos Populacionais, São Paulo, v. 9, n. 1, p. 3-21, 1992, jan./jul. 1992

SMOLKA, M. O.; CENECORTA, I. O Paradoxo da regularização fundiária: Acesso a Terra Servida e Pobreza Urbana no México. Cadernos IPPUR/UFRJ, Rio de Janeiro, v. XIV, n. 1, p. 87-118, 2000.

SOJA, E. W. Geografias Pós-Modernas: a reafirmação do espaço na teoria social crítica. Rio de Janeiro: Jorge Zahar, 2003.

SOUZA, J. L. B.; YUJI, C. Processos de Gestão do Capital de Giro. 76f. 2009. Monografia (Disciplina Administração Financeira) - Faculdade de Economia, Administração e Contabilidade, Universidade de São Paulo, Ribeirão Preto, 2009.

SOUZA, M. L. de; RODRIGUES, G. B. Planejamento urbano e ativismos sociais. São Paulo: UNESP, 2004.

SOUZA, M. L. de. A 'reconquista do território', ou: Um novo capítulo na militarização da questão urbana. 2010. Disponível em: <http://passapalavra.info/?p=32598> Acesso em: 11 mar. 2011

SPOSITO, M. E. B. A urbanização da sociedade: reflexões para um debate. In: CARLOS, A. F. A.; DAMIANI, A. L.; SEABRA, O. de L. S. (orgs.). O espaço no fim do século: a nova raridade. São Paulo: Contexto, p. 83-99, 1999.

SWYNGEDOUW, E. Social Power and the Urbanization of Water: Flows of Power. Oxford: Oxford University Press, 2004.

TEIXEIRA, F. J. S . Economia, Política e Luta de Classes em O Capital, de Karl Marx. In: MENEZES, A. M. D.; FIGUEIREDO, F. F. (Org.). Trabalho, Sociabilidade e Educação: Uma Crítica à Ordem do Capital. Fortaleza: Editora Universidade Federal do Ceará - UFC, p. 169-180, 2003.

TEIXEIRA, R. A. Dependência, desenvolvimento e dominância financeira: a economia brasileira e o capitalismo mundial. 2007. Tese (Doutorado em Teoria Econômica) Instituto de Pesquisas Econômicas, Universidade de São Paulo, São Paulo. 2007.

TEIXEIRA, R. A. Positivismo, Historicismo e Dialética na Metodologia da Economia. 2003. (Mestrado em Teoria Econômica) - Instituto de Pesquisas Econômicas, Universidade de São Paulo, São Paulo, 2003.

TELLES, V. da S. Favela, favelas: interrogando mitos, dogmas e representações. Resenha do livro de Licia do Prado VALLADARES. A invenção da favela: do mito de origem à favela (Rio de Janeiro, Editora FGV, 2005. 204 páginas.). In: Revista Brasileira de Ciências Sociais, vol. 21, n. 62, São Paulo, 2006 (Resenha). 
TELLES, V. da S. Ilegalismos urbanos e a cidade. Novos Estudos. $n^{\circ}$ 84, p. 153 - 173, julho $-2009$.

TORRES, A. T. G.; VIANNA, P. Água um Subproduto das Empresas Transnacionais e as Resistências Locais. In: Anais do Encontro da Nova Cultura da Água, Fortaleza, UFC, p. 1-18, 2005.

TOVAR, L. A água é um direito, não uma mercadoria. 2002. Disponível em: <http://www.osverdes.pt/public_htm/agua_aud.html> Acesso em: 26 out. 2010

TOVAR, L. A privatização dos Serviços de Água. 2003. Disponível em: <http://www.resistir.info/agua/serv-agua.html> Acesso em: 26 out. 2010

TUNDISI, J. G.; TUNDISI, T. M. A água. São Paulo: Publifolha, 2005.

VAINER, C. As escalas do poder e o poder das escalas: o que pode o poder local. Cadernos IPPUR. Ano XV, n. 2, ago-dez 2001/Ano XVI, n. 1, jan-jul 2002. p. 13-32

VALLADARES, L do P. A gênese da favela carioca: a produção anterior as Ciências Sociais. Revista Brasileira de Ciências Sociais, São Paulo, v. 15, nº 44, out. 2000.

VALLADARES, L. do P. A Invenção da Favela. Rio de Janeiro: FGV, 2006.

VAllaDARES, L. do P. Passa-se uma casa: análise do Programa de Remoção de Favelas do Rio de Janeiro. Rio de Janeiro: Zahar, 1980.

VARGAS, M. C. O negócio da água: riscos e oportunidades das concessões privadas de saneamento no Brasil. Estudos de caso no Sudeste brasileiro. São Paulo: Annablume, 2005.

VARGAS, M. C.; LIMA, R. F. de. Concessões privadas de saneamento no Brasil: bom negócio para quem? Campinas. Ambiente e Sociedade, v. 7, n. 2, p. 67-93, 2005.

VEIGA NETO, F. C. A Construção dos Mercados de Serviços Ambientais e suas Implicações para o Desenvolvimento Sustentável no Brasil. 2008. 298f. Tese (Doutorado em Ciências Sociais) Curso de Pós-Graduação em Desenvolvimento, Agricultura e Sociedade, Universidade Federal Rural do Rio de Janeiro, Seropédica, 2009.

VERÍSSIMO, A. A. Santa Cruz e a Fazenda Nacional: notas sobre a situação fundiária. Coleção Estudos Cariocas. Rio de Janeiro: PCRJ/SMU/IPP, 2004.

VETTER, D. M. Espaço, valor da terra e equidade dos investimentos em infra-estrutura no município do Rio de Janeiro. In: Revista Brasileira de Geografia, n. 112 p. 23-34. Rio de Janeiro, IBGE, 1979.

VEYRET, Y. (org.) Os riscos: o homem como agressor e vítima do meio ambiente. São Paulo: Contexto, 2007.

VICTORINO, V. I. P. Luz e poder na dramática conquista do meio natural. A privatização dos rios paulistanos e a reflexividade socioambiental. 2002. Dissertação (Mestrado) Faculdade de Filosofia, Letras e Ciências Humanas, Departamento de Sociologia, Universidade de São Paulo. São Paulo, 2002.

VIEIRA, A. L. da C. Considerações Iniciais para uma Agenda de Investigação sobre a Zona Oeste. Novo Enfoque, 2004. (mimeogr.)

VILLAR, P. C.; RODRIGUES JUNIOR, G. S. O Direito Humano à Água. $3^{\circ}$ Seminário Internacional Ciência e Tecnologia na América Latina. Campinas, UNICAMP, Caderno de Resumos, v. 1, 2006 
ZIZEK, S.. A visão em paralaxe. São Paulo: Boitempo, 2009.

\section{Documentos:}

ASSEMBLÉIA LEGISLATIVA DO ESTADO DO RIO DE JANEIRO RELATÓRIO FINAL DA COMISSÃO PARLAMENTAR DE INQUÉRITO DESTINADA A INVESTIGAR A AÇÃO DE MILÍCIAS NO ÂMBITO DO ESTADO DO RIO DE JANEIRO. COMISSÃO PARLAMENTAR DE INQUÉRITO (RESOLUÇÃO No 433/2008) 288p.

BANCO INTERAMERICANO DE DESARROLLO - BID Crecimiento económico sustentable: documento de estrategia. BID: Washington, D.C, Agosto de 2003a. 28p.

BANCO INTERAMERICANO DE DESAROLLO - BID. Medio ambiente. BID: Washington, D.C, Agosto de 2003b. 35p.

BANCO INTERAMERICANO DE DESAROLLO - BID. Estrategia para el manejo integrado de los recursos hídricos. Washington, D.C., Diciembre de 1998. 37p.

BANCO INTERAMERICANO DE DESAROLLO - BID. Politicas Operativas Sectoriales - Saneamiento Basico Ambiental. Washington, D.C., Agosto de 1994. 5p.

BRASIL. Ministério das Cidades. Plano Nacional de Saneamento Básico - PLANSAB. Grupo de Trabalho Interministerial para a elaboração do Projeto Estratégico do Plano Nacional de Saneamento Básico - Grupo de Acompanhamento do Conselho das Cidades. Brasília, Agosto 2008.

CENTRO DE PROMOÇÃO DA SAÚDE. A Iniciativa de Vila Paciência. Rio de Janeiro: CEDAPS, 2004. Disponível em <http://www.cedaps.org.br>. Acesso em: 10/05/2010, 8p.

CENTRO INTEGRADO DE ESTUDOS E PROGRAMAS DE DESENVOLVIMENTO SUSTENTÁVELL. Relatório de Atividades - Ano 2003. Rio de Janeiro: CIEDS, 2004.

INSTITUTO BRASILEIRO DE ADMINISTRAÇÃO MUNICIPAL. Estudo de avaliação brasileira sobre urbanização de favelas e regularização fundiária. Relatório Final, v. 1. Rio de Janeiro: IBAM, 2002

DIAGNÓSTICO SÓCIO AMBIENTAL DA COMUNIDADE DE VILA PACIÊNCIA. Resultado do mapeamento. Rio de Janeiro: CIEP 183 João Vitta, 2009. 15p.

BRASIL. Lei n ${ }^{\circ} 9.433$ de 08 de janeiro de 1997. Dispõe sobre a Política Nacional de Recursos Hídricos. Diário Oficial da União. Brasília, DF, 9 jan. 1997.

RIO DE JANEIRO (Município). Projeto de lei complementar $n^{\circ}$ 25/2001 Dispõe sobre a política urbana do município, instituindo o plano diretor da cidade do Rio de Janeiro. Substitutivo $\mathrm{n}^{\mathbf{0}}$ 3. Rio de Janeiro, 2001.

Segurança, tráfico e milícia no Rio de Janeiro / organização, Justiça Global - Rio de Janeiro: Fundação Heinrich Böll, 2008.

OBSERVATORIO DE FAVELAS. Os muros nas favelas e o processo de criminalização. Rio de Janeiro: maio de 2009.

PLANO ESTRATÉGICO DA PREFEITURA DO RIO DE JANEIRO 2009 - 2012. Pós2016 O Rio mais integrado e competitivo. Rio de Janeiro. 2009. 
RIO DE JANEIRO (Município). Secretaria Municipal de Urbanismo. Proposta do Poder Executivo para a revisão do Plano Diretor da Cidade do Rio de Janeiro - Antecedentes e Diagnósticos. Rio de Janeiro. 2009.

BANCO INTERAMERICANO DE DESARROLlO. Compañía de Agua Y Alcantarillado del Estado de Rio de Janeiro (CEDAE) - Cooperación técnica para el programa de mejora de la eficiencia comercial y operativa (BR-T1034) Plan de operaciones. Washington: BID, 2006 10p.

PREFEITURA DA CIDADE DO RIO DE JANEIRO. O Momento 2000 do programa Favela-Bairro: avaliação com base nos censos 1991 e 2000. Coleção Estudos Cariocas. Rio de Janeiro: SMU/IPP/PCRJ, 2005.

ORGANIZAÇÃO DAS NAÇÕES UNIDAS. Declaração Universal dos Direitos da Água. Conferência Internacional de Água e Meio Ambiente (ICWE) - Dublin: ONU, 1992.

FRENTE NACIONAL DE SANEAMENTO BÁSICO. Manifesto pelo saneamento ambiental. Brasília, ASSEMAE, 2010.

PREFEITURA DA CIDADE DO RIO DE JANEIRO. Favela-Bairro: avaliação da primeira fase. Rio Esudos n ${ }^{\circ} 165,2005$. (mimeogr.)

COMPANHIA ESTADUAL DE ÁGUAS E ESGOTOS, 2010. Disponível em: //www.cedae.com.br. Acesso em: 11/12/2009.

\section{Reportagens:}

AGUILLAR, C. O. La gestión comunitaria del agua en Cochabamba. Desinformémonos, REVISTA DE BAIRRO BIMESTRAL. n. 7 - Junho / Julho 2010. Depoimento a Matteo Dean. Disponível em: www.desinformemonos.org. Acesso em 10 de junho de 2010.

BASTOS, I. Segunda fase do Morar Carioca prioriza favelas perto de áreas olímpicas. O Globo Online, 27 jan. 2011. Disponível em: <www.oglobo.globo.com> Acesso em: 23 mai. 2011

BARBOSA, L. F. Cabral quer choque de gestão na CEDAE. O Globo Online, 14 set. 2006. Disponível em: <www.oglobo.globo.com> Acesso em: 23 nov. 2009

BARROS, J. A. A ofensiva contra a Canudos do mal. O Globo Online, 28 jun. 2007, Um raio-x da segurança. Disponível em: http://oglobo.globo.com/rio/ancelmo/reporterdecrime. Acesso em: 20 de outubro de 2009.

ENGELBRECHT, D. Um xodó deixado de lado. O Globo, Rio de Janeiro, 20 jan. 2006. RIO, p.21.

FACINA, A.; MC Leonardo. O funk no contexto da criminalização da pobreza. Brasil de Fato, São Paulo, 01 jan. 2009. Disponível em //www.brasildefato.com.br. Acesso em: 22 jun. 2010.

JUNGBLUT, C.; MAGALHÃES, E. Maior parte da sobra no orçamento com empréstimo do Bird será investida no programa Morar Carioca. O Globo Online, 03 ago. 2010. Disponível em: <www.oglobo.globo.com> Acesso em: 23 mai. 2011

LIMA, R. Muito além do Favela Bairro. Boletim IETS, Rio de Janeiro, 26 ago. 2009.

RAMALHO, S. A migração dos bandidos expulsos pelas UPPs. O Globo, Rio de Janeiro, 24 jan. 2010. RIO, p. 23. 
RAMALHO, S. Milícia comandada pelo ex-PM Chico Bala cobra até pela venda de água na Zona Oeste. O Globo Online, 10 nov. 2010. Disponível em: <www.oglobo.globo.com> Acesso em: 26 nov. 2010.

SALES, M. Funk carioca: o batidão entre a perseguição e a resistência. Caros Amigos, São Paulo, jun. 2009, p. 42-43.

SARAIVA, J. Empresas públicas copiam ferramentas da gestão privada. Valor Econômico, São Paulo, 26 jun. 2009. Recursos Humanos. Disponível em: www.ValorOnline.com.br Acesso em: 6 out. 2009

SEABRA, O. L. C. A várzea pertence ao rio. O Estado de S. Paulo, São Paulo, 12 dez. 2009. Aliás, p. 4. Depoimento a Ivan Marsiglia.

VICTER, W. A melhor água do mundo. O Fluminense, Niterói, 12 abr. 2009. Cidades, p.1-2. Depoimento a Simone Ronzani.

VICTER, W. Nova CEDAE começa a ser preparada para abertura de capital. O Globo, Rio de Janeiro, 15 mai. 2009. RIO, p. 21.

VICTER, W. Wagner Victer: um executivo que tem o desafio como combustível, Construir - Revista da Associação das Empresas de Engenharia do Rio de Janeiro, $n^{\circ}$ 47, ago. 2009, p. 12-15. Depoimento a Verônica Coutinho.

\section{Sítios eletrônicos regularmente consultados:}

APAFUNK, 2010. Disponível em: //www.apafunk.blogspot.com.

ARMAZÉM DE DADOS, 2010. Disponível em: //www.armazemdedados.rio.rj.gov.br

COMPANHIA ESTADUAL DE ÁGUAS E ESGOTOS, 2010. Disponível em: //www.cedae.com.br

FAVELA TEM MEMÓRIA, 2010. Disponível em: //www.favelatemmemoria.com.br

IBGE - CENSO 2010. Disponível em: http://www.censo2010.ibge.gov.br/

IBGE, 2010. Disponível em: http://www.ibge.gov.br/home/

MINISTÉRIO DAS CIDADES, 2010. Disponível em: //www.cidades.gov.br

OBSERVATÓRIO DAS FAVELAS, 2010. Disponível em:

//www.observatoriodefavelas.com.br

OBSERVATÓRIO DAS METROPOLES, 2010. Disponível em: //web.observatoriodasmetropoles.net

SECRETARIA MUNICIPAL DE HABITAÇÃO. Disponível em: //www.rio.rj.gov.br/habitacao

SECRETARIA MUNICIPAL DE OBRAS. Disponível em: //www.rio.rj.gov.br/obras

SECRETARIA MUNICIPAL DE URBANISMO. Disponível em: //www.rio.rj.gov.br/smu 


\section{APÊNDICE A}

\section{Questões norteadoras para entrevistas nas favelas pesquisadas:}

1) Há quanto tempo você mora na favela/comunidade/conjunto habitacional? Como veio morar aqui?

2) Você sabe um pouco da história da favela/comunidade/conjunto habitacional? Sua ocupação? Os primeiros moradores?

3) Você percebeu alguma mudança na favela/comunidade/conjunto habitacional do momento em que você veio morar aqui para agora?

4) Quais você acha que são as maiores qualidades da favela/comunidade/conjunto habitacional? E os principais problemas?

5) Como está a questão do saneamento básico (água, esgoto, enchentes e lixo) na favela/comunidade/conjunto habitacional?

6) Tem água na sua casa todo dia? E na favela/comunidade/conjunto habitacional tem todo dia?

7) Quando falta água como você faz para estocá-la?

8) Como é viver um dia sem água?

9) Há obras para melhorar o abastecimento de água? Já viu ou já soube da CEDAE fazendo reparos, obras ou construções na favela/comunidade/conjunto habitacional?

10) Quais os motivos que você acha que são os responsáveis pela falta d'água/irregularidade no sistema?

11) E o Estado tem alguma responsabilidade por esse problema?

12) Como você acha que o Estado trata essa parte da cidade? E as outras partes?

13) Já apareceram políticos na favela/comunidade/conjunto habitacional prometendo melhorias? Foram realizadas?

14) Você se sente representado (ideias, projetos, perspectivas) por esses políticos?

15)Lembra/Soube de intervenções de infra-estrutura/obras realizadas na favela/comunidade/conjunto habitacional nos últimos anos? E as intervenções do Favela Bairro (quando for uma favela/comunidade/conjunto habitacional que foram realizadas intervenções)?

16) Alguma delas envolvia melhorias no saneamento básico?

17) Há Associação de Moradores na favela/comunidade/conjunto habitacional? Para você qual é o papel da Associação de Moradores? 
18)Há programas/projetos sociais/ONGs na favela/comunidade/conjunto habitacional? Desenvolvendo quais tipos de atividades?

19) Qual a sua relação com as favelas/comunidade/conjuntos habitacionais no entorno? Você freqüenta lugares em outras favelas (escola, hospital, áreas de lazer, mercados)?

20) Em outras favelas/comunidades/conjuntos habitacionais no entorno há melhorias?

21)Em relação as favelas do entorno, como está a sua favela/comunidade/conjunto habitacional? Melhor, pior, igual? Por quê?

22) Se você pudesse escolher um outro lugar da cidade para morar onde você moraria? Por quê?

23) Enfim, o que você acha da sua favela/comunidade/conjunto habitacional?

24) Você poderia me recomendar outras pessoas que possa conversar sobre essas mesmas questões? 


\section{APÊNDICE B}

\section{A questão do abastecimento de água na cidade do Rio de Janeiro: um balanço historiográfico}

\section{Introdução ou $\mathbf{i}^{77}$ ou urbanismo colonial: mitos e desafios}

A cidade do Rio de Janeiro teve boa parte de sua história voltada para a conquista de áreas inundadas. Cresceu dominando mangues, brejos, pântanos e lagoas e, mais tarde, aterrando zonas de mar (BERNARDES, 1962; LAMEGO, 1964; ALMEIDA, 2006; 2008). Mas a história da cidade também foi a de uma luta árdua pelo abastecimento de água ${ }^{78}$. Nosso intuito nesse apêndice ${ }^{79}$ é compreender a história do espaço urbano colonial até a contemporaneidade através da apropriação das águas, primordialmente ao que se refere ao abastecimento no Rio de Janeiro.

O período em questão compreende, inicialmente, os debates entre 1502, data da expedição de André Gonçalves e Américo Vespúcio que descobre a Guanabara ${ }^{80}$ e as dificuldades e conflitos subsequientes na busca por fontes de água potável até 1876-1880

\footnotetext{
${ }^{77}$ Em tupi, o substantivo água é diminuto, apesar de sua abundância. Água resume-se a uma letra: i (ig). É considerado em diversas tradições indígenas como o princípio, o que principia, o que gera.

${ }^{78}$ Entre os autores que explicitam a problemática citamos Abreu (1992), Almeida (2006; 2008), Bernardes (1962), Noronha Santos (1940), Magalhães Corrêa (1939), ANA (2007), Silva (1965), Coaracy (1965), Bruno (1947), Nascimento e Silva (2008), Lamego (1964), Cabral (2010) ou tangenciam as discussões Abreu (2008), Benchimol (1992), Cavalcanti (1997; 2004), Nóbrega (2003), Nunes (1999), Oliveira (2007), Fridman (1999), Fernandes (2008), Bulhões e Reis (1980), Custódio (2008), Bernardes (1960; 1961; 1962) e Marques (2000).

${ }^{79}$ Esse apêndice foi construído nos primeiros contatos que tivemos com a questão do abastecimento de água entre os anos de 2007 e 2008. Seguimos, porém outros caminhos teóricos e outras trilhas. Inquietos em debater esse trabalho, decidimos expor esse apêndice no relatório de qualificação e fomos estimulados a manter esse esforço de pesquisa. Agradeço nesse sentido as enormes contribuições das professoras Odette Seabra e Elizete Menegat (que compuseram a banca de qualificação), à professora Beatriz Bueno pelas sugestões e debates na disciplina "História da Urbanização e do Urbanismo do Brasil" (na FAU-USP) e a Lucas Marchezin pelas enormes contribuições históricas. Os eventuais equívocos que permanecem, porém, são de nossa responsabilidade.

${ }^{80}$ Brandão (2005) expõe que essa versão predominante da descoberta e denominação do Rio de Janeiro foi apresentada por Varnhagen e apoiada em relatos das cartas de Américo Vespúcio que foram publicadas no início do século XVI. Vespúcio teria participado como cosmógrafo nas duas primeiras expedições enviadas para explorar a recém descoberta Terra de Vera Cruz a convite da Coroa Portuguesa especificamente por D. Manuel. Brandão (2005, p. 2) remonta, porém um histórico de contestações acerca dessa perspectiva: em 1914, por Morales de los Rios e, posteriormente, pelo historiador português Joaquim Veríssimo Serrão. Os argumentos dos autores centram-se na inexistência nas cartas de Vespúcio de referências, direta ou indireta, de sua passagem pela Guanabara. Todavia, esta versão permaneceu predominante na historiografia. Brandão (2005, p. 2) disserta ainda que em abril de 1940, o navegador português Gago Coutinho publicou um artigo que demonstra a "total ignorância de Vespúcio na arte de navegar". Gago Coutinho ressaltou a impossibilidade da participação deste como cosmógrafo como, inclusive, põe em dúvida se sequer esteve presente nas primeiras explorações portuguesas ao Brasil. Ao desenvolver esta crítica, Gago Coutinho nos apresenta a seguinte questão: "Se as naus de Vespúcio tivessem, como ele afirma, abordado a costa para Oeste do Cabo São Roque, teriam, como disse, de voltar a centenas de léguas ao largo, a fim de o poderem balaventear e montar a costa do Natal. Assim impõe os ventos e correntes ali dominantes: tanto a navegação de Gama (1497) como a de Cabral (1500) provam que, em 1501, já os pilotos portugueses sabiam traçar as rotas de modo a evitarem o risco de se ensacarem na costa mais ocidental do Brasil"' (COUTINHO, 1941:60 apud BRANDÃO, 2005: 2)
} 
momento em que foi iniciado e concluído o primeiro sistema de encanamento de abastecimento domiciliar da cidade, o que definitivamente rompe com o sistema colonialescravista $^{81}$. É importante destacar que até meados do século XIX, predominou, na cidade, o que Jaime Benchimol (1992) interpretou como um "sistema colonial-escravista de distribuição de água". Compreendemos, porém que se pode analisar um "sistema colonialescravista de abastecimento de água”, pois já nesse período havia uma economia política da água, com soluções em certa medida integradas e disputas em todas as etapas do abastecimento: ou seja, na captação e reservação, distribuição, armazenamento, consumo ou gestão. Em suma, havia um desenvolvimento em germe de uma economia política do abastecimento de água, nesse sentido, compreender os conflitos que se estabelecem no uso e apropriações desiguais desse recurso no sistema colonial-escravista é um primeiro objetivo.

Em um segundo momento tentamos explicitar brevemente o processo de transformação da cidade em metrópole a partir das disputas pelo controle, apropriação e propriedade da água.

Aprofundemos o primeiro momento. $\mathrm{O}$ sistema colonial escravista de abastecimento de água era assim realizado através de duas redes interconectadas como expõem Benchimol (1992) e Cabral (2010). A primeira delas, desenvolvida pela Coroa Portuguesa e, posteriormente, pelo Império era a rede "técnica", isto é os sistemas de engenharia (SANTOS, 2008) ou obras hidráulicas (MARQUES, 2000) compostos pelos encanamentos que captavam a água nas altas nascentes e a levavam até pontos de coleta dentro do espaço urbano (bicas, bicames - encanamento provisório feitos de calhas de madeira e descoberto - e chafarizes, estes últimos com maior importância devido a sua maior vazão de água.

A outra rede, como descrevem Cabral (2010) e Benchimol (1992), era movimentada pelos "corpos humanos orquestrados pela instituição da escravidão": negros domésticos e de ganho que coletavam a água e a transportavam em barris aos seus senhores ou a vendiam pelas ruas da cidade. Com o crescimento da demanda, até mesmo brancos pobres entraram no negócio em meados do século XIX (KARASCH, 2000[1987] apud CABRAL, 2010)

Além disso, ressalvamos que mesmo compreendendo ser esta tarefa ambiciosa, há uma lacuna nos estudos acerca do abastecimento de água e o despejo de esgoto relacionado à história da urbanização e do urbanismo durante o período colonial brasileiro. Os esforços

\footnotetext{
${ }^{81}$ Frisamos a compreensão da diferença entre o período colonial (com encerramento formal em 1822) e o período escravista (com fim do tráfico negreiro em 1850 e abolição da escravatura em 1888). Porém, reafirmamos nossa periodização a fim de compreender a dotação de infra-estrutura e serviços de abastecimento de água e o processo de urbanização na cidade do Rio de Janeiro. Num primeiro momento a cidade colonialescravista entre 1502/ 1876-1880, a passagem da cidade à metrópole entre 1880-1960 e a metropolização posterior a 1960 .
} 
mais recentes de Abreu (1992), Marques (2000), Britto (2001), ANA (2007), Cabral (2010), Rezende e Heller (2008), Custódio (2010) dentre outros, todavia não podem ser negligenciados.

Para iniciar os debates acerca do urbanismo colonial destacamos consoantes a Lahuerta $(2008$, p. 17) que o ato de relacionar geografia e história para o entendimento de realidades coloniais além de possível é necessário para se evitar os equívocos de transportar os estudos das formas fixas do presente para o exame do passado, sem perceber seu dinamismo.

Nessa perspectiva, pensar a cidade do Brasil no passado é a proposta que Abreu (1996) lança como questão que nesse trabalho abraçamos como tarefa inicial. Em contraposição aos últimos sessenta anos, que elevaram a cidade a uma posição cada vez mais destacada na estrutura social brasileira, transformado inclusive em tema privilegiado de estudo da Geografia (ABREU, 1994) no longo período que antecede a esse momento de urbanização da sociedade, a importância da cidade como objeto de reflexão foi substancialmente menor.

Para Abreu (1996:146) "a cidade como materialidade social diferente do campo destacou-se como objeto de reflexão no Brasil do passado". Porém as teses que destacavam uma total autarquização do campo frente à cidade ou que observavam acumulações somente endógenas à colônia vêm sendo questionadas. Por exemplo, destaca-se que principalmente a partir do século XVIII há uma extensa rede de abastecimento do mercado interno comandadas pelos grandes comerciantes urbanos da colônia, dentre outros inúmeros fatos que apontam para novas reflexões (ABREU, 1996:149). É vital então assinalar que nossa compreensão é de que há uma relação contraditória, conflituosa e complementar entre cidade e campo desde o período colonial brasileiro.

Reis Filho (1968) propõe que a política urbanizadora deve ser entendida como um esforço para controlar ou influir sobre as transformações que ocorrem num processo de urbanização. No caso brasileiro, "em decorrência do regime colonial, Portugal se colocava na origem das transformações do sistema social, como agente da política de colonização e, como parte importante dessa, da política de urbanização”. (REIS FILHO, 1968:66). Fundamenta seu pressuposto na análise da História brasileira a partir de sua urbanização, sendo seminal em tais discussões.

Para Reis Filho (1995), a relação colonial era necessariamente uma relação de dominação e que só pode ser conhecida quando se examinam ambos os lados (metrópole e colônia). Sistematicamente a Colônia é descrita como simples resultado de decisões tomadas 
pela Metrópole. Na prática havia uma adaptação recíproca de ambas, uma adaptação dos agentes sociais envolvidos numa relação interdependente, todavia acentuadamente desigual.

O urbanismo, segundo Reis Filho (1995) deve ser conceituado como forma de intervenção sistemática na organização do espaço urbano de uma dada sociedade, no caso do Brasil

[...] seu desenvolvimento só pode ser explicado quando se tem em vista as características da política de urbanização, nas diferentes escalas e níveis de configuração do espaço, do intra-urbano ao regional e ao espaço das relações internacionais, como as regiões das metrópoles e colônia (...) não existe um urbanismo espontâneo e outro dirigido. Qualquer uma das formas é determinada socialmente sendo sempre configurações da estruturação das relações sociais. (...) A história do urbanismo colonial é a história dos esforços para controle do espaço urbano das relações sociais, no quadro da dominação colonial. (REIS FILHO, 1995:5)

Conforme discorre Fernandes (2008) predominou até bem recentemente a idéia de que, diferentemente das cidades de colonização espanhola, nossas cidades sofriam da ausência de planejamento, sendo legítimas herdeiras do desleixo e do espontaneísmo que seriam característicos do urbanismo islâmico ${ }^{82}$, medieval e português. Como salientou Brenna (1996:415), desde Sergio Buarque de Holanda, passando por Robert Smith e Leonardo Benevolo, esta racionalidade foi amplamente justificada, concretizando o que Delson (1979) conceituou de "mito da cidade sem planificação". O suposto de que as cidades construídas pelos portugueses no Brasil não foram planejadas ou reguladas começou a ser questionado por autores tais como Reis Filho (1968), Delson (1979), Araújo (1992) e Rossa (2002), dentre outros autores. Ao contrário do que caracterizam explicações consagradas (tais como HOLANDA, $1984^{83}$; SMITH, $1954^{84}$ ) o Estado português teve "um papel muito importante na organização territorial e urbana da colônia do que aquele que é geralmente admitido" (ABREU, 1996:150). A estratégia foi muito mais planejadora do que se pensava. Nela estiveram envolvidos diversos engenheiros militares que pensavam a cidade não só em termos

\footnotetext{
${ }^{82}$ Sobre o urbanismo islâmico verificamos que há uma definição de que as formas e funções da arquitetura muçulmana se caracterizariam como uma espécie de resposta às necessidades sociais e religiosas, o que corresponde a um quadro de prosperidade e de abundância de projetos construtivos. Porém há uma idéia difundida de ausência de normas e de espontaneísmo das construções e do projeto arquitetônico. Acerca desses conceitos Sampayo (2001) rebate essas argumentações manifestando que a cidade islâmica apresenta uma forma urbana organizada com princípios de ordem e hierarquização do espaço. Para a autora o habitat, os planos e as instituições da cidade islâmica foram concebidos pela adequação ao meio físico e da vida privada do povo muçulmano.

${ }^{83}$ Segundo Holanda (1984:76) “a cidade que os portugueses construíram na América não é produto mental, não chega a contradizer o quadro da natureza, em sua silhueta se enlaça na linha da paisagem. Nenhum rigor, nenhum método, nenhuma previdência sempre em significativo abandono que exprime a palavra 'desleixo'."

${ }^{84}$ Para Smith (1954 apud ABREU, 1996:151) "Os portugueses estabeleceram no Brasil, quase intacto um mundo que haviam criado na Europa... a ordem era ignorada pelos portugueses. Suas ruas, ironicamente chamadas de "direitas", eram tortas e cheias de altos e baixos, as praças eram geralmente irregulares... Nada inventaram os portugueses em relação a planificação de cidades em países novos."
} 
de lógica militar, mas como elementos de um sistema urbano maior, conforme aponta Bueno (2001). A criação de vilas e cidades no Brasil colonial, como a elevação de vilas à categoria de cidade, obedeceram a um projeto de política territorial muito mais abrangente do que é geralmente admitido.

Se a afirmação consagrada de Holanda (1984) pode servir para explicar o padrão que se desenvolveu a partir do crescimento de algumas vilas fundadas por donatários, ela certamente não se aplica a todos os núcleos urbanos fundados no período colonial e muito menos a cidades reais, fundados pela Coroa portuguesa tais como Salvador, Rio de Janeiro, João Pessoa, conforme analisado por Abreu (1996:152). No caso do Rio de Janeiro, a suposta desarrumação das cidades e desleixo certamente não ocorre. Por exemplo: as decisões tomadas relativas à medição e à arruação das sesmarias de chão, isto é dos lotes urbanos doados para a formação da cidade se prolongam por todo período colonial. Nesse ponto destaca-se a relação entre Igreja e Estado, pois na falta de normas civis específicas para a conformação urbana, as leis eclesiástica são então definidoras para o estabelecimento das atividades e dos caminhos da expansão territorial, conforme demonstra Fridman (1999). A autora ainda aponta que "o clero impôs normas expressas para o assentamento dos edifícios e das propriedades sagradas. $\mathrm{O}$ uso do solo carioca mostrou, portanto, um jogo de forças que teve expressão jurídica e política" ${ }^{\Perp 55}$.

Esse complexo processo, acreditamos, pode ser elucidado através de diversas perspectivas; a que elegemos como primordial para esse apêndice, inicialmente se refere à apropriação das águas no período colonial-escravista. Destacam-se nesse momento na literatura analisada e apoiados em Custódio (2008) a questão das águas retratadas como via de transporte e escoamento da produção de gêneros agrícolas, fonte de pesca para o abastecimento alimentício da população, direcionadora da ocupação do território e orientadora natural no processo de criação de cidades, marco fronteiriço entre freguesias, demonstrações de status na casa de vivenda ao mostrar ao visitante a imensidão de terra e águas possuídas (FREYRE, 1957), apontamento para a direção na procura de áreas de mineração a partir do aparecimento nos leitos dos rios do ouro de aluvião e fonte de energia hidráulica para a

\footnotetext{
${ }^{85}$ Fridman e Macedo (2006) argumentam que as ordens religiosas tiveram um papel importante na história da urbanização da colônia. Os autores exemplificam que as ordens religiosas foram agentes de organização de atividades da vida cotidiana do Brasil colonial: abriam ruas em troca de terras, forneciam água em suas carroças para a população nas invasões estrangeiras, ofereciam bois ao Governador para alimento de residentes de sua casa e de sua comitiva, foram responsáveis pela educação, pela saúde e outras estruturas As ordens religiosas eram proprietárias de terras e imóveis no campo e na cidade (engenhos, fazendas, olarias, estaleiros, armazéns e propriedades). Essas acumulações eram possibilitadas pelas doações de famílias nobres e pela Coroa, e também através de compras. Autores como Fridman (1999), Fridman e Macedo (2006), Abreu (2008) e Prieto (2008) argumentam que essas propriedades são importantes vetores de expansão da cidade.
} 
produção nos engenhos de açúcar. Entretanto, iremos nos ater às construções geográficas da captação e reservação dos sistemas de engenharias de distribuição de água e do armazenamento público e privado (a rede técnica). E das práticas geográficas da distribuição pelos aguadeiros (a rede movimentada pela instituição da escravidão) e do consumo diferenciado entre as classes sociais. Além de pormenorizar as políticas para a adução de água. Em suma, compreender o abastecimento de água da população carioca e a urbanização da cidade que esse propicia.

\section{Reconstituindo os desígnios ${ }^{86}$ da produção do espaço carioca a partir do abastecimento de água}

Logo após a descoberta do Brasil, navegantes portugueses lançaram-se ao conhecimento de novas terras para o sul do continente. A expedição de André Gonçalves e Américo Vespúcio no dia $1^{\circ}$ de janeiro de 1502 avistou a foz do que supunham ser um rio. Seguiu-se Gonçalo Coelho, que se introduziu rio adentro e vislumbrara o contorno de uma extensa baía, à esquerda de quem nela penetrava, encontrou uma aguada desejada na embocadura de um pequeno curso de águas límpidas (SILVA, 1965). Prontamente, as embarcações utilizaram-no como ponto de abastecimento, porém o curso d'água inseria-se em terras dos tamoios que dele se utilizavam e atribuíam àquelas águas virtudes notáveis. Para a proteção da aguada providencial foi armada uma fortificação de pedra (ou casa de pedra) onde morava o homem branco (carioca) ${ }^{87}$.

Os franceses de Villegagnon e de Bois-le-Comte ali também iam se abastecer. E também os portugueses e vicentinos moradores da Cidade Velha que Estácio de Sá fundara ao sopé do Pão de Açúcar, junto ao Morro Cara de Cão (o sítio da Carioca ou Arraial de São Sebastião). O lugar era propício a emboscadas de tamoios e franceses, e "as crônicas primitivas nos dão notícia de mais de um recontro ali ocorrido" (COARACY, 1965:128).

Coaracy (1965) analisa ainda que antes de atirar-se ao combate para desalojar os franceses da ilha fortificada de Villegagnon, Mem de Sá simulou o desembarque na praia "onde forte arroio corre de altas florestas", o que os ocupantes da Ilha entenderam como a

\footnotetext{
${ }^{86}$ Para maiores desdobramentos ver Bueno (2001 [2003]).

${ }^{87}$ De acordo com Nóbrega (2003:144), existem várias traduções e explicações para o termo "carioca”. Para uns, ela traduziria a água corrente da pedra. Para outros, casa da fonte; ou ainda casa do branco, corrente saída do mato ou do monte, casa da corrente, do mato... Há também a atribuição para a origem da palavra cari ou acari, o peixe cascudo, tão comum nos rios e muito comido pelos indígenas. Carioca seria paradeiro, abrigo, casa dos acaris. Três razões poderiam ter levado os povos originários a chamar o português de carioca: ou porque este tivesse feito sua casa a beira do rio que já era conhecido por Carioca ou Acarioca uma vez que era a morada dos acaris; ou porque usasse roupa grossa a lembrar o casco duro dos referidos peixes, ou ainda, porque a casa feita pelos portugueses era toda de pedra, e também dava a idéia da casca grossa do acari.
} 
tentativa de cortar-lhes a água de que se abasteciam. Correndo para defendê-la, os franceses enfraqueceram a defesa do forte, do que se valeu Mem de Sá para atacá-los e impor a derrota aos franceses.

Cavalcanti (1997) e Nóbrega (2003) sustentam que o sítio da Carioca fora a área escolhida, inicialmente, para nela erguer a cidade logo após a expulsão dos franceses por apresentar: a construção de uma fortaleza, um porto e "boa água, este último apenas o sítio da carioca apresentava" $^{\$ 8}$ (CAVALCANTI, 1997:46-47). Apesar do paradeiro do foral e do regimento do Rio de Janeiro ser desconhecido Reis Filho (2000) e Cavalcanti (1997) entendem que deve assemelhar-se àquele estabelecido em Salvador por Tomé de Souza para a fundação da cidade:

[...] a dita fortaleza forte e que se possa defender e que tenha disposição e qualidade para aí por tempo em diante de ir fazendo uma povoação grande e tal qual convém eu seja dela se proverem as outras capitanias como com a ajuda de nosso senhor espero que seja e deve ser em sítio sadio e de bons ares e que tenha abastança de água e posto que em que bem possam amarrar os navios e vararem-se quando cumprir porque todas estas qualidades ou as mais delas que puderem ser cumpre que tenha a dita fortaleza e povoação. (grifo nosso, regimento de Tomé de Souza (17 de dezembro de 1548, apud REIS FILHO, 2000:21).

A transferência da cidade visando um local mais propício à defesa fez com que Mem de Sá fundasse, em $1^{\circ}$ de março de 1567 , um novo núcleo de povoamento no alto do extinto Morro do Castelo. Assim o Arraial de São Sebastião fora abandonado. A precariedade das instalações e a exigüidade de seu sítio conduzem a hipótese de que esse arraial nunca deve ter sido pensado como um embrião de uma cidade e sim apenas como um acampamento militar (NÓBREGA, 2003; CAVALCANTI, 1997; 2004; ABREU, 1992; BERNARDES, 1960; 1961; VASCONCELOS, 2006). Assim compreendemos que o posterior abandono do sítio da Carioca não pode ser encarado como "atitude tateante e perdulária dos portugueses" (HOLANDA, 1984:26), mas sim uma atitude de estratégia militar ${ }^{89}$.

As dificuldades eminentes da escolha do sítio no Morro do Castelo são demonstradas por Cavalcanti (2004) e Abreu (1992), pois a área carecia de fontes naturais de abastecimento,

\footnotetext{
${ }^{88}$ Ao fundar a Cidade, Estácio de Sá ordenou abrir poços cuja água pudesse ser considerada “em termos de poder beber, [pois] não houvesse mais que uma lagoa de água ruim [e] não desconhecia como perigoso seria ir disputar aos tamoios a posse da água do Rio Carioca". (SILVA, 1965:21)

89 Vasconcelos (2006) parece realçar tal paradigma quando afirma que foram fatores determinantes para a seleção do Morro do Castelo como o sítio da cidade: a localização, a possibilidade de crescimento do lugar e a defesa. Para Moreira (2006) a organização espacial da sociedade começa com a prática da seletividade. Esta para o referido autor é uma espécie de ponte entre a história natural e a história social, já que a seletividade é o processo de eleição do local com que a sociedade inicia a montagem de sua estrutura geográfica. "Ela é uma expressão direta e combinada dos princípios da localização e da distribuição. Por meio da localização o homem elege a melhor possibilidade de fixação espacial de suas ações. A distribuição compõe o sistema de localizações e transforma a seletividade numa configuração de pontos e o todo numa extensão" (MOREIRA, 2006:82).
} 
e essa situação obrigava os moradores a construírem poços com muita profundidade, tarefa assaz dispendiosa e onerosa. O poço mais acessível ao uso público da população - o Poço do Porteiro - ficava no sopé desse morro.

A transferência da cidade para o Morro do Castelo propiciou à cidade condições de futuras expansões, à extensão das várzeas circundantes ${ }^{90}$, a partir dessa ocupação foi possível o acesso a água em poços menos profundos, tal comodidade era descompensada pela má qualidade do líquido que "não ofereciam mais do que uma água salobra" (ABREU, 1992:56).

Por essa razão continuou o rio Carioca a servir de fonte primordial de abastecimento de água na cidade. À medida que a população crescia, o comércio de água aumentava, essa se tornou proibitiva para muitas pessoas em função do alto custo do serviço dos aguadeiros. No que concerne à divisão social do trabalho de abastecimento de água fica bastante visível que é predominantemente trabalho escravagista a tarefa de fazer a água chegar aos ambientes onde será consumida. Índios aguadeiros, a serviço de seus senhores, percorriam as ruas levando as águas em igaçabas, barris ou talhas de barro, posteriormente os escravos negros assumiram tais tarefas de mercantilização. Além de dispendiosa e onerosa a empreitada pela busca de água no rio Carioca era do ponto de vista estratégico-militar inadequado. Pois "bastava que o inimigo ocupasse a antiga praia do Sapateiro (Flamengo) para que o Rio de Janeiro fosse conquistado" (ABREU, 1992:56-57) Segundo Coaracy (1965:128) este foi no aspecto primitivo, "o primeiro serviço de abastecimento de água que existiu no Rio de Janeiro".

É também o escravo que irá sofrer literalmente na pele os rigores da lei, como se vê no caso da detenção dos que são flagrados contrariando a legislação sobre o uso da água. Para eles estava prevista, além da detenção, uma cota de açoites (penalidade corporal) enquanto do patrão, que freqüentemente era o mandante do comportamento considerado delituoso, era exigido tão somente o pagamento de multa para retirar da cadeia o criado, a penalidade pecuniária (ANA, 2007).

A sociedade carioca apresenta uma estrutura complexa já desde as primeiras décadas de sua existência e o controle sobre o abastecimento de água e o acesso na sua utilização tem relação direta com a correlação de poder das classes sociais na detenção de meios de produção e prestígio político. O direito de ter assento na Câmara e, portanto, de participar das grandes discussões e decisões sobre as questões relacionadas com a urbanização é, por mais de três

\footnotetext{
${ }^{90}$ A diversidade transforma a localização numa distribuição e faz da distribuição um habitat humano plural. A diferença hídrica, topográfica, do solo, da flora, da fauna, das casas, dos caminhos, das culturas orienta o habitat na reafirmação da diversidade (MOREIRA, 1994; 2006)
} 
séculos, privilégio exclusivo dos detentores de terras (conseqüentemente de águas) e de escravos.

À grande maioria da população, conforme aponta ANA (2007:83) “composta por escravos e homens livres e pobres, cabe obedecer às normas e regulamentos e a pagar as taxas cobradas pelos poderosos, ainda que as considere injustas face à qualidade e à quantidade de água adquirida". Todavia essas relações não se estabelecem apenas num caráter hegemônico, o acirramento de tensões e conflitos ocorre de modo ainda mais latente na construção do sistema de engenharia do Aqueduto da Carioca.

No primeiro governo de Martim de Sá ${ }^{91}$ (1602-1608) cogitou-se lançar um imposto para trazer as águas do rio Carioca até ao campo de Nossa Senhora da Ajuda. Entretanto essa empreitada foi inócua. Nova tentativa foi realizada no segundo período desse mesmo governador, entre 1623-1627, quando se ajustou com o arquiteto Domingos da Rocha um contrato segundo o qual as obras "seriam executadas no prazo de quatro meses e mediante o pagamento de sessenta mil réis, em dinheiro contado" (ABREU, 1992:57). Todavia, “devido à escassez daquele prazo e possivelmente à insignificância da quantia ajustada, nem sequer foram iniciadas as obras" (NORONHA SANTOS, 1945:7).

Em 21 de abril de 1648 decidia a Câmara pôr em arrematação a obra de conduzir as águas à cidade por meio de calhas de madeira dispostas na encosta dos morros. Em 1658, no governo de Tomé Corrêa de Alvarenga (1657-1660), os incômodos que afligiam os habitantes da cidade tinham se tornado muito sério. Pois, por um lado o próprio aumento da população tornava cada vez mais dramático a questão do abastecimento de água. Por outro, a ocupação agrícola das terras situadas no alto e médio vale do Carioca deu início a diversas situações de conflitos (COARACY, 1965; ABREU, 1992). O fato é que os moradores dos terrenos adjacentes e ao longo do Carioca, passaram a se reivindicar donos das águas correntes, impedindo seu uso comum. Dessa forma, a utilização privada dessas águas logo veio a comprometer a qualidade da água que era captada próxima a foz pelo restante da população, conforme argumenta Abreu (1992). Parte da população indignada representou na Câmara contra tais proprietários pedindo que terras, águas e matas fossem desapropriadas e ficassem perpetuamente livres e não pudessem ser aforadas em tempo algum.

Só a carta régia de 1672 forneceu os primeiros recursos financeiros para a execução da obra, consignando para esse fim a arrecadação do pequeno subsídio do vinho e metade das

\footnotetext{
91 A população crescia e reivindicava água mais próxima a cidade. Martim de Sá afirmava "ser de suma importância trazer à Cidade a água do Carioca, que tem seu nascimento no Morro do Alcovardo e dela saciar-se o povo com belas e cristalinas águas para todos os usos da comunidade particular” (apud SILVA, 1965:312).
} 
rendas das despesas da Justiça (SILVA, 1965). Logo no ano seguinte as obras foram contratadas aos mestres-pedreiros João Fernandes e Albano de Araújo e a construção teve início com solenidade e pompa: missa campal com a presença da Câmara, nobreza e povo, depois "o Governador, com uma alavanca especial deu os primeiros golpes na terra" (COARACY, 1965:129). Porém, as obras seguiram morosamente, pois aos indígenas que trabalhavam na empreitada eram somente fornecidos comida e sete varas de panos por mês. Os jesuítas reivindicavam que aos indígenas além dos produtos entregues fosse pago um salário diário de 80 réis. Depois de longos embates e a diminuição paulatina de indígenas na obra foram substituídos por escravos africanos no governo de Álvaro Silveira de Albuquerque (1702-1705) em 1704. Sua administração foi marcada pela retomada das obras após período de paralisação $(1697-1704)^{92}$, pela perseguição intensa aos judeus ${ }^{93}$ e a proteção aos proprietários fundiários, além de forte articulação junto aos jesuítas.

Outros contratempos se desencadearam no decorrer da obra. Em 1710/1711 foram novamente interrompidas devido às invasões francesas, pois todos os recursos da cidade foram investidos na defesa e posteriormente no seu resgate ${ }^{94}$.

Bicalho (2003) analisando a documentação denominada "Mémoire et Projet pour enlever Riojaneiro" comprova que a expedição do capitão-de-fragata Duguay-Trouin foi cuidadosamente planejada. A autora verificou que visando garantir o sucesso da ocupação, os franceses descreveram com destaque o Aqueduto da Carioca e, inclusive, sugere que os invasores assim que estiverem em terra firme deveriam ir direto ao aqueduto e cortar o abastecimento de água para a cidade (BICALHO, 2003). O aqueduto referido em "Mémoire"

\footnotetext{
${ }^{92}$ Em 1697, notando que tinha má direção e pouca segurança, ordenou o governador Artur de Sá Meneses que as obras fossem interrompidas. (COARACY, 1965; NÓGREGA, 2003, NORONHA SANTOS, 1945).

${ }^{93}$ Alvarez (2005) argumenta que na primeira década do século XVIII há indícios de que no Rio de Janeiro criouse uma atmosfera de procura de um bode expiatório "oficial" para as perturbações que abalavam a cidade: escassez de alimentos, escassez de água, secas prolongadas, maus odores. Isto é, parecia haver um sinal inequívoco de que Deus abandonava seu rebanho na cidade do Rio de Janeiro. Alvarez (2005) aponta que o Bispo São Jerônimo liderou uma implacável ofensiva contra a comunidade cristã-nova. A repressão atingiu um cume em 1705, pois, em carta, o governador Álvaro da Silveira e Albuquerque declarou ao seu monarca que os judeus abandonavam a cidade. Esse era "um sinal" de que os que ficavam deveriam ser presos e julgados. Entre 1703-1706 foram presos um grande contingente de pessoas particularmente mulheres. Alvarez (2005) ressalta ainda que em 1711 existia uma interpretação de que o ataque dos franceses a cidade foi uma punição dos céus para o Rio de Janeiro. Um dos integrantes da frota de guerra invasora, o tenente Du Plessis Parseau, confirmou a "premonição" atribuída ao bispo São Jerônimo (que dispunha de informes metropolitanos seguros e indicativos) de um ataque das velas estrangeiras resultado do castigo divino pelas muitas "abominações da cidade que atrairiam sem tardar as iras do Senhor".

94 Nessa época lançou-se a idéia de construção de um muro para a proteção e defesa da cidade e também como instrumento para o controle interno da cidade e de seus habitantes, essa obra apresentava um inconveniente muito grave: as fontes de abastecimento de água, na Ajuda e na Bica dos Marinheiros (mangue de São Diogo) ficaram fora dos limites do muro. Desse modo seria muito fácil ao invasor promover um cerco a cidade, cortando-lhe o abastecimento de água. Outros inconvenientes tais como o alto custo da obra e o fato de que a cidade estava em plena expansão explica o fato do projeto apresentar diversas controvérsias e não ter sido concluído, apesar de parcialmente implementado (CAVALCANTI, 1997;2004).
} 
trata-se provavelmente do primeiro trecho do aqueduto que ficou conhecido como "Arcos Velhos da Carioca" (COARACY, 1965; NÓBREGA, 2003).

Os Arcos Velhos da Carioca são atribuídos ao governo de Aires de Saldanha (17191725). Assim, “como a 'Mémoire' é anterior a $1711^{95}$, acredita-se que já havia um trecho deste aqueduto funcionando anterior ao governo de Aires de Saldanha" (NÓBREGA, 2003: 217). Os Arcos Velhos da Carioca começavam no morro das Mangueiras, flanqueavam o caminho do Desterro (atual Evaristo da Veiga) e terminavam no campo da Ajuda (atual Cinelândia), onde havia um chafariz denominado Fonte da Ajuda, segundo Cavalcanti (1997:48) esse era o primeiro chafariz da cidade "uma construção provisória em madeira". Esse deveria ser o chafariz que o Ouvidor Diogo de Sá da Rocha manda construir na correição de março de 1638 e cuja forma é descrita:

[...] faça de Outeiro, a Outeiro huma parede com suas bicas, e canos para tomar agoa; com seus poyaes de redor, para se proem os potes, e dahi para baixo e sirva para lavadouro. (apud Nóbrega, 2003:218-219)

Em 1717 depois de tantos percalços muito do que foi construído estava em ruínas, razão pela qual El-Rey autorizou não apenas o prosseguimento da obra, mas também a reparação do que havia sido feito. Exigiu também uma nova planta do traçado final do encanamento fosse desenhada. Entretanto, o governador deveria manter o projeto antigo realizando apenas modificações para corrigir os erros da obra existente.

O governador Aires de Saldanha mandou modificar o traçado do aqueduto, convencido da superioridade do projeto novo. Transferiu o local do chafariz para o campo de Santo Antônio, mesmo sem autorização da Metrópole. Em 1720, edificou no campo da Ajuda um chafariz, todavia o local ainda encontrava-se fora da cidade. Coaracy (1965) apresenta uma reprodução do projeto desse aqueduto, de autoria de Manuel dos Reis Couto datado de 1718, acompanhado do desenho, uma carta do governador Aires de Saldanha e Albuquerque, segue o desígnio

[...]Que o caminho della tem de comprimento 24.200 palmos thé á Igreja de N. Sr ${ }^{\mathrm{a}}$ da Ajuda, e 3500 thé o primeiro arco do Campo de N.Sr ${ }^{\mathrm{a}}$ da Ajuda, que fazem 27.700, e menos que da obra velha 3.300: ainda não está determinado hade continuar a obra para os arcos do Campo de N.Sra da Ajuda, se para o de Santo Antônio, que fica mais perto da cidade [...] (apud COARACY, 1965:131)

\footnotetext{
${ }^{95} \mathrm{Em} 1704$ o francês Ambrozio Jauffret nascido em Marselha e que viveu durante 30 anos em São Paulo enviou um relatório detalhado para o ministro de Marinha francesa informando sobre os estados das capitanias do sul do Brasil. Esse documento subsidiou a "Mémoire" com riqueza de detalhes sobre as rotas e condições de navegação com especial destaque para a cidade do Rio de Janeiro suas ruas, prédios, economia, etc. O relatório previa também os prováveis lucros no ataque de uma eventual empresa de corso. A "Mémoire" instruiu a empresa de Duguay-Trouin na invasão à cidade (BICALHO, 2003).
} 


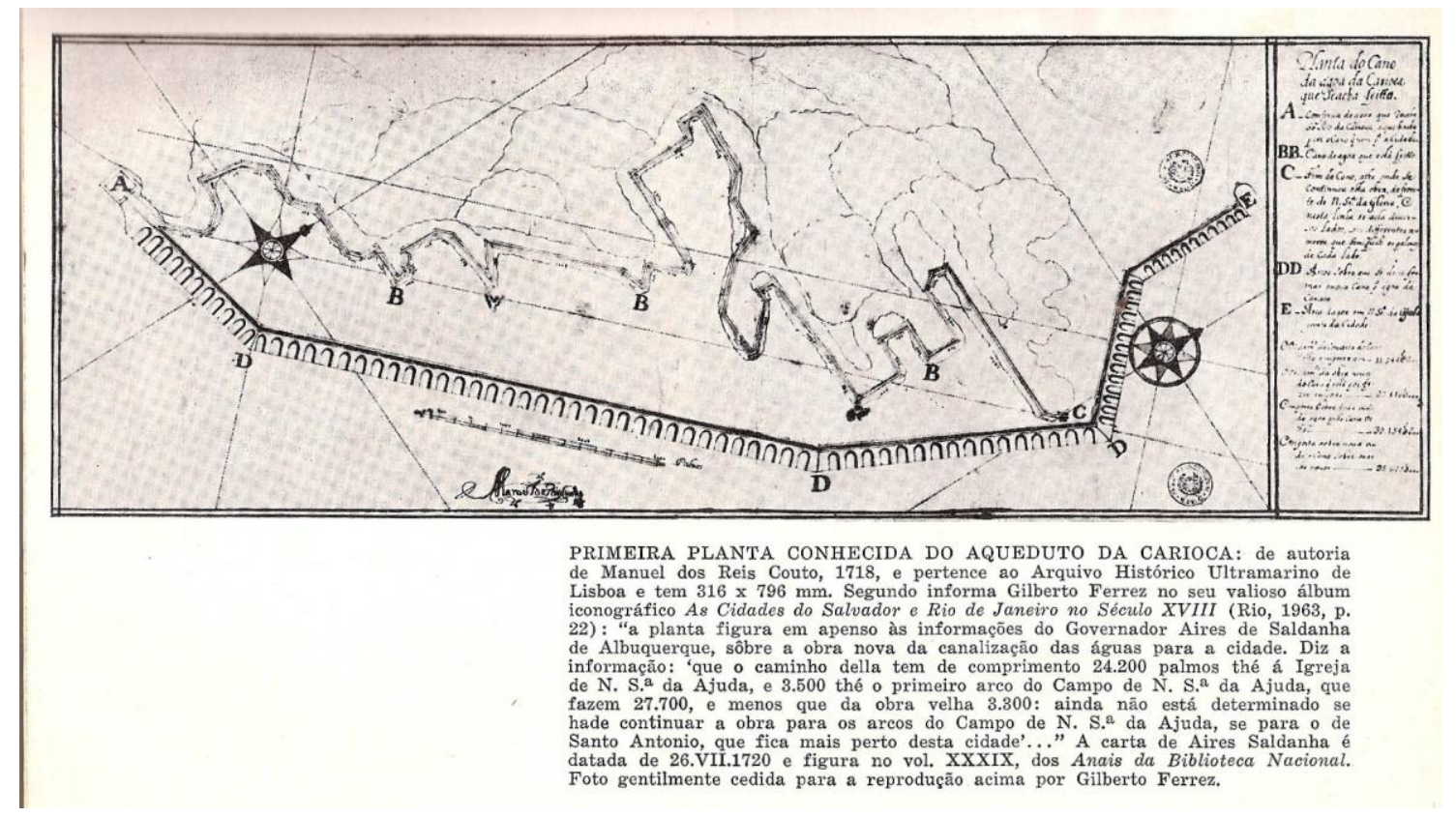

Fonte: COARACY, 1965

Imagem B1: Primeira planta conhecida do Aqueduto da Carioca.

Havia ainda dúvida sobre a alteração da direção do traçado do aqueduto, que se concretizou, para tal intento, foi realizada a modificação do local do chafariz do Campo da Ajuda para o Campo de Santo Antônio a partir de um sistema de encanamentos chamado inflexão. Em 1723 inaugura-se o primeiro grande chafariz na cidade, que viria ser chamado pela população de Chafariz da Carioca (pois provinha das águas do rio Carioca). Surgia, então, o Largo da Carioca, substituindo a antiga toponímia de campo ou largo de Santo Antônio (PEREIRA, 1999). Tendo sido aprovado o projeto, Lisboa enviou um chafariz de mármore com 16 bocas de bronze, transformando o local em ponto nevrálgico da cidade (ABREU, 1992), tornou-se o largo, antes freqüentado pelos que se dirigiam ao Convento de Santo Antônio, centro de intenso movimento (COARACY, 1965) acarretando a valorização da área (PEREIRA, 1999), tornando-se uma fundamental centralidade do Rio colonial.

No governo Gomes Freire de Andrade (o conde de Bobadela) ${ }^{96}$ um novo direcionamento do Aqueduto da Carioca foi realizado, autorizado por carta régia de 28 de abril de 1744, para corrigir o traçado sinuoso, nessa empreitada as águas advinham direto do

\footnotetext{
96 O governador Gomes Freire de Andrade (posteriormente conde de Bobadela em 1758) administrou a Capitania do Rio de Janeiro entre 1733 e 1763, Nóbrega (2003) sustenta que Bobadela é um dos principais articuladores na transferência da capital de Salvador para o Rio de Janeiro. Ao vislumbrar a possibilidade da cidade tornar-se capital do Brasil empreende uma série de obras que além de acrescentar melhorias na cidade alteraram seu caráter. Realizou "intervenções urbanas em vários setores da cidade: abastecimento de água, defesa, saneamento, saúde pública, construção de edificações públicas e marcos simbólicos que distinguissem sua administração e o poder do soberano português" como constata Nóbrega (2003).
} 
Morro do Desterro ao Morro de Santo Antônio, com dupla arcaria de pedra e cal empregando material daqui e não vindos de Lisboa, essa obra monumental foi concluída em 1750.

Com a chegada do abastecimento público dentro da cidade, ocorreu um fluxo intenso de pessoas ao Largo da Carioca. Pereira (1999) argumenta que "oficiais com carros de tração animal abasteciam as repartições públicas e palácios do Governo”. Havia ainda uma enorme quantidade de escravos que ali se justavam em busca de água para seus senhores, lavadeiras disputavam lugar nos tanques de pedras para bater roupas e aguadeiros enchiam seus carros pipas para vender água nos bairros mais afastados.

Essa movimentação acorria cotidianamente. Era uma multidão constituída de pessoas de diversas classes sociais, o que acarretava conflitos frequentes devido a inúmeros fatores: tempo de espera nas filas, a necessidade da água que ocasionava o encontro dos "diferentes", fossem eles as classes consideradas infames, ou a rivalidade entre etnias africanas, as brigas por territórios entre os que usavam as águas do chafariz (escravos, aguadeiros, lavadeiras, e até marinheiros) dentre tantas outras. Marins (2001) observou que no Rio de Janeiro os aguadeiros disputavam lugares nas fontes e chafarizes com lavadeiras num tumulto que não raro resultava em agressões. Para manter a ordem, a vigilância contínua e o policiamento da praça (FERNANDES, 2008; PEREIRA, 1999; SILVA, 1965; NÓBREGA, 2003), Gomes Freire instituiu uma guarda permanente de quadrilheiros (COARACY, 1965, PEREIRA, 1999). Competia-lhes, quando a ocorrência de pessoas era muito grande, formar filas em linha e desfazer conflitos. Essa guarda de fiscalização, principalmente relacionado à apropriação da água, a "Guarda Velha", foi a primeira guarda permanente da cidade. Segundo Coaracy (1965:134) os que pretendiam "furar filas" e os recalcitrantes, que se recusavam a obedecer às ordens, eram sumariamente induzidos a acatar as decisões dos quadrilheiros de serviço "pelo argumento persuasivo da chibata".

Contraditoriamente, esse mesmo chafariz que oferecia água, potável e dentro da cidade, deu origem a dois problemas (CAVALCANTI, 1997; 2004). Com o transbordamento dos tanques localizados na base do chafariz, um "imenso lamaçal tomou conta do largo de Santo Antônio transformando-o em foco de mosquitos e doenças. Para saná-lo foi construída em direção ao mar, uma extensa vala de escoamento que ia dar na Praia" atualmente Praça Mauá (CAVALCANTI, 2004:35). A carta régia de 21 de abril de 1725 autorizou a solução de canalizar para a Vala ${ }^{97}$ as "sobras de águas das fontes" (SILVA, 1965). O custo recaiu sobre a Fazenda Real uma vez que a Câmara não dispunha de recursos para realizá-la.

\footnotetext{
${ }^{97}$ As valas eram a grande solução para diversos problemas na cidade, como o escoamento de águas pluviais e dos dejetos da população, e eram consideradas um grande avanço técnico na resolução destas questões. Com
} 
O segundo problema atingiu o próprio rio Carioca, na prática, dividido em dois trechos, cada um deles recebendo tratamento diferenciado por parte das autoridades e da população. No trecho entre a nascente, a denominada "mãe d'água e o ponto inicial do aqueduto permaneceu em severa vigilância das autoridades encarregadas, conforme afirma Cavalcanti (1997; 2004). Contudo Coaracy (1965) argumenta que também moradores dos terrenos adjacentes à essa área desviavam as águas das calhas para proveito próprio para a irrigação de hortas, plantações e para abastecimento privado de suas residências. Para coibir tal prática foram decretadas severas penalidades, que iam até o degredo para a Costa da África.

Já o trecho que partia da "mãe d'água" e descia até o mar foi abandonado pela fiscalização pública. Nas palavras de Cavalcanti (1997) ao longo de todo o caminho instalouse um verdadeiro colar de lavadeiras, bebedouros de animais e reservatório de lixo e esgoto. Em curto espaço de tempo as águas estavam poluídas.

Apesar de tais aspetos, o Aqueduto na cidade do Rio de Janeiro é interpretado à época como uma pujante vitória do homem sobre a natureza, do construído e do meio urbanizado sobre o natural (ALMEIDA, 2006, 2008; FERNANDES, 2008). E também uma vitória do poder instituído, do governador Gomes Freire, e seu ideal de tornar a cidade capital da Colônia - a "capitalidade pressentida" conforme defende Nóbrega (2003:264-285). E também do vice-rei Luis de Vasconcelos, que dedicou esforços para a melhoria do sistema de distribuição de águas do Carioca, aterramento da Lagoa do Boqueirão e para a construção do Passeio Público; (COARACY, 1965; ALMEIDA, 2008). A inauguração do Chafariz das Marrecas marcou o coroamento da remodelação dessa área da cidade ${ }^{98}$ em 1785.

esse objetivo, o povo instava seus governantes para a construção e a manutenção delas. A primeira grande vala remonta à construção do aqueduto da Carioca e do chafariz no Largo de Santo Antônio (NASCIMENTO; SILVA, 2008).

${ }^{98}$ Presente nos trabalhos de Almeida (2008) e Fernandes (2008) encontra-se o desígnio da "vitória do homem sobre a natureza", pois com o chafariz as águas encontram-se agora "civilizadas" e não mais uma lagoa com água parada, propícia aos miasmas e doenças. Em seu lugar chega à água potável e límpida fruto do trabalho humano materializado em um sistema de engenharia. A barbárie de outrora, a lagoa onde os infames e os peões iam servir-se para a limpeza, trabalho, lazer ou despejo de dejetos fora sanada. A água do mar violenta e intempestiva foi domada e contida, em suma a inscrição no chafariz celebra essa "vitória sobre a natureza" e a vitória da política (Vice-reinado e Coroa Portuguesa): "Durante o reinado de D. Maria I e D Pedro III/Secou-se um lago outrora pestífero/E converteu-se em formas de passeio/Repeliram-se as águas do mar por insurgente muralha/Aduziram-se fontes em jorrantes bronzes [...] Ao vice-rei Luiz de Vasconcellos de Souza, sob cujos auspícios foi tudo isso realizado/ O povo do Rio de Janeiro, em sinal de grato ânimo/No dia 31 de julho de 1785." 


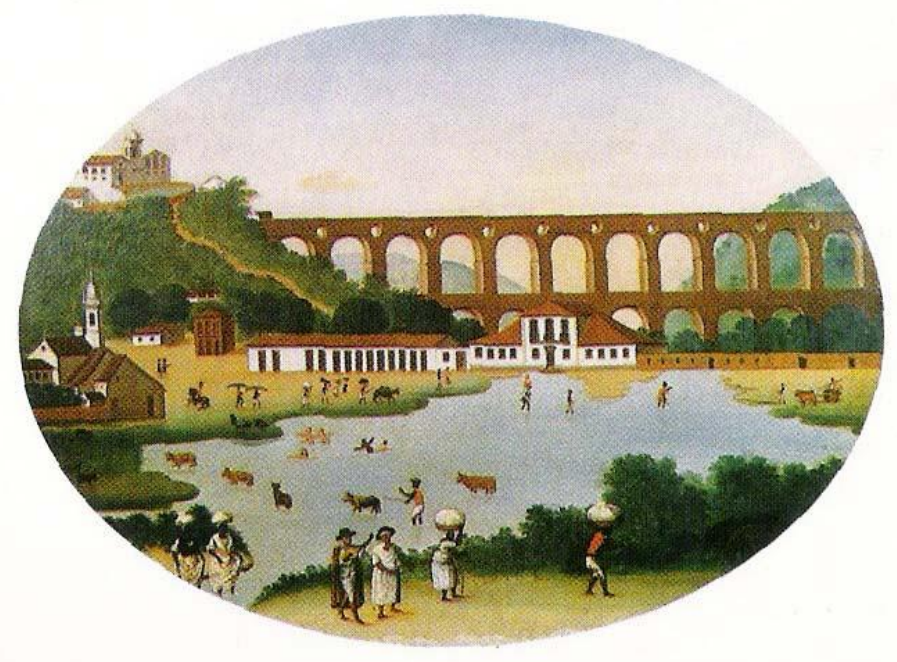

Fonte: ALMEIDA, 2008

Imagem B2: Vista da Lagoa do Boqueirão com os Arcos. Tela atribuída a Leandro Joaquim. Museu Histórico Nacional.

Conforme afirma Silva (1965) o período posterior ao momento de inauguração do Aqueduto da Carioca (1750) é a "fase dos chafarizes",99, a solução adotada nesse momento para abastecer a cidade. Quando o governador Gomes Freire assumiu a administração pública, só havia o Chafariz da Carioca, e nesse os conflitos supracitados. Dentre as várias medidas tomadas a fim de mediar tais questões foram a instituição da guarda permanente dos quadrilheiros e a obrigatoriedade das filas, como já relatado, além da construção de mais um chafariz na cidade. O novo chafariz foi erguido no centro do Terreiro do Carmo e era alimentado pela mesma caixa d'água que alimentava a Fonte da Carioca. A água era conduzida através de um cano, ao longo da atual Rua Sete de Setembro (rua do Cano anteriormente). Projetado por Carlos Mardel esse chafariz foi transferido para a beira do cais com a finalidade de facilitar a aguada das embarcações por ordem do vice-rei Luis de Vasconcelos e Sousa, nessa ocasião fora reformado por Mestre Valentim. Para Nóbrega

\footnotetext{
${ }^{99}$ Conforme confirma Cavalcanti (2004:36) "A rede de abastecimento de água construída pelos vice-reis somavam 11 chafarizes: a) Chafariz da Carioca, no antigo campo de Santo Antonio, depois chamado Largo da Carioca. Construção do governo Aires Saldanha; b) primeiro chafariz no Largo do Paço, obra do Conde de Bobadela, Gomes Freire de Andrade no centro da praça, posteriormente demolido; c) chafariz de Mestre Valentim, obra de d. Luís de Vasconcelos e Souza no Largo do Paço em substituição ao construído pelo Conde de Bobadela, ainda hoje existe; d) chafariz da Gloria, no caminho da Gloria, obra do Marques do Lavradio; e) Poçinho da Gloria, no Largo da Gloria, obra antiga; f) chafariz das Marrecas, na Rua dos Barbonos realização de d. Luís de Vasconcelos e Souza; g) fonte dos Amores, projeto do mestre Valentim, no Passeio Público, obra também de d. Luís de Vasconcelos e Souza; h) chafariz do Largo do Moura, obra do Conde de Rezende; i) chafariz do Largo do Capim, também do Conde de Rezende; j) chafariz no Campo de Santana, o chafariz das lavadeiras, obra iniciada no governo do vice-rei d. Fernando Jose de Portugal; k) chafariz do Lagarto, na altura da lagoa da Sentinela, hoje rua Frei Caneca, obra do governo d. Luís de Vasconcelos e Souza, posteriormente alguns outros, como por exemplo o chafariz de Sta. Rita."
} 
(2003:278) "o fato de Bobadela ter mandado localizar o novo chafariz no centro do Terreiro do Carmo (atual Praça XV), evidencia o caráter do chafariz como marco da autoridade política da época", visto a centralidade desse ponto da cidade, as inscrições latinas confirmam "enquanto Phebo com seu ignífero carro os povos queima", D. Maria I, Bobadela e Vasconcelos "com as águas expele da cidade a sede" (SILVA, 1965:317).

Várias derivações de fontes e chafarizes foram efetuadas a partir do Aqueduto visando melhorar o abastecimento da cidade e descentralizar o Largo da Carioca, mas as águas já não eram suficientes e seu volume estava drasticamente reduzido devido ao crescente desmatamento das matas ciliares da serra da Carioca para disponibilização de carvão e lenha.

Em tal administração, uma nova empreitada para o abastecimento de água se faz, quando a administração resolve valer-se de outros rios (CAVALCANTI, 1997). Pois, ao chegar as águas depois de mais de cem anos de espera não são mais suficiente para a demanda da cidade. O Rio de Janeiro não somente era porto controlador e exportador de ouro das minas gerais, como a partir de 1763, a capital da Colônia, o que acarretou num grande incremento demográfico (ABREU, 1992; COSTA, 2002).

Essa nova posição ocupada no sistema colonial português atraía cada vez mais tropeiros na ligação com os planaltos auríferos e soldados para a defesa de invasões e para coibir o contrabando, comerciantes vindos sobretudo da metrópole, além de viajantes e emissários da Coroa. Abreu (1992:59) argumenta que "o dinamismo demográfico fez-se sentir também no campo circunvizinho que viu expandir a atividade agrícola, tanto a de exportação, quanto de consumo interno". Finalmente para consolidar esse dinamismo econômico numa etapa de acumulação mercantil-capitalista baseado na escravidão como sustentação, o tráfico negreiro é reforçado como fonte de recepção e distribuição de força de trabalho cativa como ressalta Abreu (2008).

A decisão tomada é pela captação de água no Rio Maracanã, no mesmo maciço montanhoso que o rio Carioca, porém mais distante. Em 1800 já estava pronto o plano para a adução que deveria "principiar(...) pela construção do açude no lugar chamado Boa Vista" (Memória para o princípio do cano, caixa d' água e açude para esta cidade apud Abreu, 1992:60).

Em março de 1808 com a chegada da Família Real se "tornou imperioso o reforço do abastecimento de água em tempo curto", pois já era notável que o fornecimento, apenas com a rede existente era insuficiente para atender a demanda da agora capital da Corte e seu crescimento vertiginoso de milhares de pessoas 
A vinda da Família Real para o Brasil ${ }^{100}$ e a conseqüente instalação da capital do império lusitano no Rio de Janeiro modificou a cidade e gerou conseqüências na problemática da água. Tais fatos podem ser vistos de diversas maneiras, tanto no aumento de habitações e no conseqüente aumento das valas, quanto na ocupação de pântanos que impediam a cidade de se expandir, ou no aumento de chafarizes e de fontes pela cidade, visando uma melhor distribuição do abastecimento de água ${ }^{101}$. (NASCIMENTO E SILVA, 2008).

Em 1809, em meio à profunda seca e estiagem, foi promulgado o Edital do Intendente de Polícia Paulo Fernandes Viana determinando que enquanto não se concluísse o encanamento do Maracanã agora custeada pela Real Fazenda, só se permitisse o acesso ao chafariz da Carioca a escravos que a ela concorressem com barris na cabeça. Carroças e pipas deveriam se abastecer nas fontes e poços das chácaras vizinhas à cidade, e para tanto receberam ordem do Príncipe Regente para franqueá-las “durante esta calamidade (...) sem molestarem os que a eles concorrerem, e que fazendo o contrário serão castigados (...) com prisão e outras demonstrações" como cita Maurício Abreu (1992). Entretanto, a ordem de D. João VI ocasionou embates pois os proprietários se recusavam a permitir a utilização das fontes de água por terceiros. O aqueduto da Carioca deveria ser vistoriado para verificar a existência de vazamentos e de desvios de água, as embarcações deveriam fazer suas aguadas nas bandas d'além (atual cidade de Niterói) da Baia da Guanabara, os encanamentos que abasteciam diretamente os conventos deveriam receber apenas uma quantidade fixa.

Em 1817 em meio a mais uma seca e a diminuição drástica da vazão do Rio Carioca, o rei mandou demarcar as "terras de coutamento" proibindo cortar madeiras, lenhas e matos [d]"os terrenos pelo alto da Serra que rodeiam as nascentes da água da Carioca, e ao longo do Aqueduto desde a última nascente até o morro de S. Teresa" (MINUTA, 1817 apud ABREU 1992).

O primeiro encanamento do rio Maracanã posteriormente conhecido como encanamento velho foi concluído em 1823, reunindo uma série de mananciais e de redes de abastecimento outrora provisórios. Todavia, a ocorrência de nova seca em 1824 demonstrou

\footnotetext{
${ }^{100}$ Como capital do Império português entre 1808-1821, o Rio sentiu o efeito dessas transformações. "Os limites físicos da cidade rapidamente se expandiram; a população urbana quase dobrou, a economia urbana cresceu e diversificou-se e a vida cultural da cidade sofreu mudanças significativas." (MARTINS E ABREU, 2004:212)

${ }^{101}$ Já em 1808 o Príncipe Regente verifica a necessidade de captação de água em pontos alternativos. Pois deveria "cuidar-se em meter mais água na Cidade, e diversos bairros dela, e essa água pode ser a chamada do Maracanã, sobre o que há projeto desde muitos anos" (MAGALHÃES CORRÊA, 1939). No ano de 1809 ocorreu uma profunda seca que demandou a construção de um bicame (posteriormente um chafariz), das Lavadeiras (pois, os tanques que o cercavam eram freqüentadas por lavadeiras para a lavagem de roupas, além de local corá-las e secá-las) e a construção provisória do encanamento no rio Comprido aumentando com isso a vazão do chafariz do Lagarto.
} 
categoricamente que a problemática ainda estava longe de ser resolvida. Em 1833, uma companhia com capitais brasileiros e ingleses se candidatou a fazer chegar água encanada às residências, mas não foi bem sucedida. Períodos constantes de secas e estiagens se sucederam sendo a mais grave delas em 1843.

Em 1840, observando um mercado em ampla expansão e a ineficiência do abastecimento, fundou-se uma empresa para explorar o serviço de "Pipas d' Água" transportado por frotas de carroças, porém distribuía apenas uma pequena parcela das águas aproveitadas no sistema de chafarizes.

Desde as primeiras décadas do século XIX, ocorre a expansão da malha urbana da cidade possibilitada pela mobilidade das classes sociais mais abastadas que podiam se deslocar para sítios e chácaras em locais mais amenos e menos povoados com lençóis de água, rios e riachos com melhores condições de salubridade e potabilidade ${ }^{102}$. Posteriormente, no último quartel do século XIX com o desenvolvimento de um sistema de transporte através de bondes e trens a cidade se expande categoricamente (ABREU, 2008).

“Água de beber” e "água de lavagem”, essa diferenciação, na qualidade da água comercializada, estratificava ainda mais a sociedade, pois diferenciava aqueles que consumiam uma ou outra (ABREU, 1992; PRIETO, 2008). Tal categórica diferença significa que:

“esta era a razão pela qual a existência da primeira sempre proporcionava
maior vantagem ao vendedor. Água de beber era água pura, vinda de
nascentes situadas dentro da propriedade. A outra era água do rio ou riacho,
já utilizada à montante para satisfazer as necessidades de outros usuários. E
essas necessidades eram as mais variadas possíveis desde a lavagem de
roupa propriamente dita à movimentação de moinhos e à utilização na
indústria”. (ABREU, 1992:67)

Com a construção do novo encanamento de água do rio Maracanã (em 1850) e a conseqüente ampliação significativa do abastecimento de água tornou-se possível a melhoria da distribuição e o aumento da oferta no centro da cidade e nas áreas próximas com pontos ainda não-abastecidos ${ }^{103}$.

\footnotetext{
${ }^{102}$ Abreu (1992:67) demonstra que os anúncios dos jornais cariocas do século XIX atribuíam relevância significativa ao acesso a fontes e chafarizes próprias de abastecimento de água através de chácaras e terrenos para aqueles que poderiam se dar ao luxo de morar fora do atual Centro da Cidade. Em 1831, o Diário do Rio de Janeiro noticiava "de uma chácara muito boa, em Andaraí Pequeno, com proporções para tudo muito boa água de beber e lavagem e boas vargens para capim".

${ }^{103}$ Melhor abastecida a partir de 1850, a cidade do Rio de Janeiro viu essa vantagem ser anulada, a partir desse mesmo ano pela incidência de febre amarela e de outras doenças contagiosas que passaram a matar quantidade significativa de pessoas, devido às precárias condições de higiene da cidade. Ocorreram embates científicos entre os que acreditavam na teoria miasmática (os que acreditavam que as doenças advinham de emanações pestíferas através de valas e pântanos ainda não saneados) e aqueles que apostavam que a epidemia era transmitido por um vetor mais específico que simplesmente o "ar". Marques (2000) apresenta brilhantemente esse debate.
} 
A qualidade do urbano passou a fazer parte do cotidiano da cidade ou pelo menos das classes dominantes. Abandonar a cidade empestiada tornou-se então objeto de desejo daqueles que podiam se mobilizar pelo território e habitar fora da área central comprando terrenos, sítios e/ou chácaras numa cidade ainda precária em termos de transporte público.

Assim, a partir do século XIX, se intensifica na cidade do Rio de Janeiro o processo de transformação da forma urbana e uma estrutura espacial ainda mais radicalizada na diferenciação das classes sociais, com a divisão social e territorial do trabalho mais complexificada ${ }^{104}$.

Em 1850 (data emblemática do fim do tráfico negreiro e da instituição da lei de Terras no Brasil), iniciou-se a "modernização" do sistema de distribuição de águas, com a instalação de rede domiciliar com tubos de ferro e aparelhos hidráulicos importados da Inglaterra, sob a supervisão de engenheiros contratados, em sua maioria no exterior. Consoantes a Benchimol (1992) concordamos que o capital - e com ele, uma nova base tecnológica penetrou na esfera de uma necessidade vital, potencializada pelo crescimento da população e pelo conjunto de transformações sócio-econômicas que revolviam a estrutura urbana da cidade.

Essa clara passagem do meio natural para o meio técnico não fez com que a economia "natural" da água desaparecesse ${ }^{105}$. Ao lado do sistema de comercialização (que beneficiou os setores privilegiados da população) substituiu durante muito tempo, a forma de distribuição em barris (ou sua versão moderna: as latas d'água) mobilizando não mais milhares de escravos mais proletários, escravos de suas próprias necessidades como expõe Benchimol (1992).

Assim nas palavras de Bulhões e Reis (1980:231)

[...] nas estalagens ou cortiços onde vivem aglomeradas centenas de indivíduos, eram os moradores obrigados a fazer longas viagens se queriam conseguir água (...). As águas do Rio da Carioca (...) principalmente (...) tinham ido gradualmente minguando, de modo que ao findar o terceiro quartel do século XIX, achavam-se já reduzidas a insignificante lacrimal, insuficiente quase para alimentar regularmente o afamado chafariz da Carioca.

Entretanto, se a modernização da rede de distribuição a domicílio era um índice da modernização da cidade o número também de excluídos do acesso a esse bem vital constituía um indicador da qualidade social dessa modernização.

\footnotetext{
${ }^{104}$ Até então, o Rio era uma cidade apertada, limitada pelos Morros do Castelo, de São Bento, de Santo Antônio e da Conceição. Ocupava, todavia, um chão duramente conquistado à natureza, através do dissecamento de brejos e mangues que já durava mais de três séculos. Além dos morros havia apenas alguns tentáculos, que se dirigiam aos sertões do sul, do norte e de oeste como expõe Abreu (2008).

105 Essa substituição desencadeou a desagregação da forma colonial-escravista de abastecimento de água, qual seja: a mobilização cotidiana de um contingente considerável da população escrava urbana para desempenhar um serviço inscrito na esfera privada da unidade doméstica do senhor. Esse sistema desagregou-se rapidamente, por força do encarecimento e da escassez da mão-de-obra (BENCHIMOL, 1992).
} 
O sistema de encanamento sob pressão (as penas d'água) foi o utilizado para o abastecimento domiciliar de água, todavia esse sistema chegou a saturação rapidamente. Em 1866 o inspetor geral de Obras Públicas alertava o ministro do Império das "contínuas representações da população da cidade à falta no abastecimento de água" (BENCHIMOL, 1992; ABREU, 1992). Medidas emergenciais foram tomadas pelo governo imperial na figura do engenheiro André Rebouças, porém medidas contra foram tomadas por proprietários de terras onde se localizavam os mananciais e cursos d'água que a comissão queria canalizar para abastecer a população. Estruturou-se uma violenta campanha, envolvendo muitas figuras notáveis e influentes da época, mas provisoriamente se conseguiu sanar a demanda. As elites hegemônicas, proprietárias de terras e escravos, tentavam normatizar os usos do território na consolidação de seus interesses específicos e de suas demandas, na tentativa ferrenha de manutenção do uso privado das águas.

Em 1876 o abastecimento de água foi considerado como serviço público administrado pelo Estado, em compensação, entregava às empreiteiras a construção do novo sistema de abastecimento assegurando-lhes a garantia de juros para o capital investido nas obras. A principal recompensa econômica residia no fornecimento de materiais, tais como tubos de ferro fundido e de chumbo, registros, válvulas, torneiras e aparelhos hidráulicos, pontes e pontilhões, trilhos, locomotivas, vagões ${ }^{106}$.

Inaugurado, sob contrato do governo imperial com o auspicioso empreiteiro (cidadão inglês e construtor do sistema de abastecimento de Viena) Antonio Gabrielli em 1880, o novo sistema de abastecimento de água foi celebrado como início de uma nova era para a vida e a salubridade da capital do Império. O sistema ampliou enormemente o volume de água fornecido à cidade e deu grande impulso à rede de abastecimento domiciliar, mas a solução definitiva foi em muito pouco tempo superado pelo crescimento urbano e o contínuo

\footnotetext{
106 Benchimol (1992:73-74) demonstra que inicialmente o abastecimento de água foi disputado por duas companhias, uma delas inglesa, mas permaneceu como serviço de administração pública. Já o serviço de esgotos foi entregue, sem hesitação, em 1862, à Companhia The Rio de Janeiro City Improvements, criada pela casa bancária Gleen and Mills. A rede de esgoto era considerada um desastre pelas camadas privilegiadas que dela usufruíam, a situação era ainda mais dramática para trabalhadores que moravam, em sua maioria, nas habitações coletivas da zona central da cidade. Obedecendo assim à lógica capitalista de servir melhor quem paga melhor, a companhia inglesa contribuiu para acentuar as diferenças qualitativas e estratificar o espaço urbano carioca. $\mathrm{O}$ serviço de esgoto conjuntamente com o abastecimento de água teve um papel ativo no processo de especulação e valorização da terra urbana, desbravando fronteiras, juntamente com carris e as empresas loteadoras. As redes, sobretudo no período republicano, ultrapassavam constantemente os limites já povoados da cidade, penetrando em áreas que estavam sendo preparadas para se transformar em áreas fabris e de moradia proletária ou mais constantemente de valorização urbana de áreas para moradia e lazer das classes burguesas conforme expõe magistralmente Jaime Benchimol (1992).
} 
desmatamento, deixando os mananciais a descoberto e a população ainda exposta às secas nas estiagens $^{107}$.

Paralelo a tais fatos, Marques (2000) argumenta que nesse momento já se explicita a consolidação da medicina social como campo de intervenções demonstrando uma passagem das ações sobre o corpo dos indivíduos para o corpo social e coletivo. A teoria miasmática está sendo posta em prática nas intervenções de normatização e planejamento das cidades. Intensifica-se progressivamente o combate as águas paradas e aos locais considerados insalubres, porém esses não são mais os únicos territórios de intervenção. As habitações operárias, os locais de aglomerações e reivindicação dos pobres e a própria multidão são manifestação do temor das doenças e das pestes. Porém um espectro põe ainda mais temor às classes burguesas: a revolução proletária.

Nesse momento são realizadas inúmeras modificações na vida urbana com uma série de serviços públicos sendo implantados tais como a iluminação a gás nas ruas do centro na década de 1860, o primeiro trecho da ferrovia Estrada de Ferro Dom Pedro II que ligará definitivamente os subúrbios as áreas centrais em 1868 e a implantação de bondes a tração animal. A vida privada é transformada com inovações técnicas nas edificações como, por exemplo, a introdução dos banheiros com bacias sanitárias e outras instalações domiciliares (MARQUES, 2000:59).

\section{Uma economia política do sistema colonial-escravista de abastecimento de água em São}

\section{Sebastião do Rio de Janeiro}

Observamos em análise uma economia política da água que definimos apoiados em Benchimol (1992), Abreu (1992) e Abreu (2008) como colonial-escravista para compreender o período entre 1502-1876/1880. O sistema de abastecimento colonial-escravista fazia-se no que se refere à captação e reservação em aguadas (embrionariamente voltadas para o atendimento de embarcações que atracavam no pequeno povoamento português para

\footnotetext{
${ }^{107}$ A escolha inicial foi o aumento da proteção às captações de água nos mananciais do Maciço da Tijuca o que resultou inclusive no reflorestamento da Floresta da Tijuca durante a década de 1870, que anteriormente havia sido uma área desmatada para a produção de cafés (ABREU, 1992; MARQUES, 2000). Todavia, no bojo de situações de estiagens pregressivas e para a consolidação da infra-estrutura recentemente inaugurada, o governo imperial busca fontes abundantes de abastecimento fora da cidade Daí surge o sistema determinado de "Sistema Acari ou de Linhas Pretas", que foi utilizar-se das águas da serras de Duque de Caxias e Nova Iguaçu, que são as captações de Santo Antônio (1877), Rio D'Ouro (1880), Tinguá (1893), Xerém (1907) e Mantiqueira (1908), cortando toda a Baixada Fluminense e trazendo esta água para a Metrópole. As captações de regimes torrenciais e até o ano de 1940, representavam 80\% do volume de água disponível (SILVA, 1965; ANA, 2007). As duas primeiras foram fruto dos serviços de A. Gabrielli. A inauguração desse sistema de abastecimento de água é retratada de maneira debochada pela Revista Ilustrada (1880): "Ficamos tão maravilhados da grande quantidade desse precioso líquido que chegamos a acreditar que tínhamos o Niágara diante de nós" como expõe Abreu (2008).
} 
exploração da costa brasileira), poços públicos e fontes. A distribuição realizada por meio de aqueduto $^{108}$, bicas, bicames, carroças de pipas d'água, chafarizes e por meio de serviço prestado pelos aguadeiros. Acerca do armazenamento, isto é, os sistemas, estruturas e utensílios são principalmente igaçabas, barris, talhas e moringas de barro, além das cisternas, uma prática "privada" comum para o recolhimento e armazenamento da água da chuva (BENCHIMOL, 1992).

Quando se passa a analisar o acesso ao consumo, a relação de classe social fica mais consubstancial. Fridman (1999) identifica três classes sociais no Rio de Janeiro colonial. A primeira era a nobreza composta por fidalgos, pelos primeiros colonizadores portugueses, pelos cavaleiros d' El Rey e pelo alto funcionalismo público, além de corporações militares, ordens religiosas, grandes comerciantes e proprietários. Como apontam Fridman (1999), Cavalcanti (1997, 2004) e ANA (2007) os detentores de alguma forma de poder, possuíam mananciais para abastecimento próprio ou quando isso não ocorria, a mão-de-obra escrava era utilizada para transportá-la independentemente da distância. A classe situada mais abaixo é exemplificada nas seguintes atividades: oficiais mecânicos, os trabalhadores artesãos, os pequenos comerciantes, mercadores e tratantes, além dos médicos e enfermeiras mantidos por religiosos que formavam a classe dos peões ou plebeus (FRIDMAN, 1999:21) com poder aquisitivo compravam o líquido à porta de casa, comercializada pelos aguadeiros. Porém a terceira classe, dos infames, ao qual se inseriam criminosos, desterrados, judeus, cristãosnovos, mouros, excomungados, ciganos, indígenas e negros - escravos ou libertos, os mais pobres ou considerados inferiores, quando não possuíam alguma fonte de renda para adquirir água, restava ir buscá-las nas bicas e poços abertos ao público, enfrentando as filas, o peso dos recipientes transportados por longos trajetos e, muitas vezes, as disputas pelo acesso à água.

A gestão da água, ou em outras palavras, a lógica política das ações e objetos que determinam a apropriação das águas é analisada à luz de um sistema político-institucional e sua estrutura de poder, das classes sociais, instituições, ações e medidas governamentais, relações Estado - Sociedade, níveis de organização e reivindicaçõos. Nesse enfoque verificamos as normatizações que instituem a dotação de infra-estrutura, além de abastecer a população tais políticas urbanizam o território ${ }^{109}$.

\footnotetext{
${ }^{108}$ Aqueduto mais restritamente ao Rio de Janeiro, pois "quase que apenas nessa cidade, se empreendeu uma obra desse porte" (BRUNO, 1947:8).

${ }^{109}$ O território é compreendido tal como em Fridman (1999:13) considerado como resultado do poder político exercido pelas classes sociais. Assim, o desenho urbano retrata os processos de acumulação e de parcelamento do patrimônio fundiário.
} 
Sendo assim, um aqueduto como o da Carioca significa muito mais que o desenvolvimento de uma rede técnica para o abastecimento de água, é símbolo do poder de um Império, no caso o português (MUNFORD, 1992; ALMEIDA, 2006). Nas áreas periféricas da metrópole, "somente um vislumbre ocasional de planejamento urbano, um templo, uma fonte, um pórtico e um jardim, despertaria um eco nobre do centro da cidade" (MUNFORD, 1992:60). Importante ressaltar que as fontes e chafarizes são sinônimos de áreas urbanizadas (ALMEIDA, 2006). Para Nóbrega (2003:260-261) o monumento manifesta valores históricos, políticos e ideológicos que constituem o fundamento da autoridade ${ }^{110}$, não informa apenas através da arquitetura de igrejas e palácios, mas de obras monumentais e de equipamentos urbanos como chafarizes, muito utilizado no período de urbanismo barroco, acumulando assim a função utilitária de abastecimento de água e a função simbólica, política e ideológica de um monumento. Eram elementos simbólicos de representação da metrópole e do governador. As inscrições nos chafarizes geralmente são longas, escritas em latim e fazem referência ao governo no qual foi construído. No Rio de Janeiro se impunham na paisagem como um monumento com todos esses valores agregados e como representação da autoridade governamental (NÓBREGA, 2003; ALMEIDA, 2008).

O modelo de gestão governamental do período se apresenta com os aspectos mais evidentes, no caráter político eminentemente normativo e fiscalizador no período que analisamos (ANA, 2007). A Coroa portuguesa "se insinuava por todas as dimensões da vida urbana, e muito especialmente nas cidades reais" (ABREU, 1996:155). A autonomia municipal $^{111}$, conquistada nos tempos medievais e transferida para o Brasil, assegura às cidades e vilas fazer justiça em nome do rei e legislar sobre o que era de seu peculiar interesse, porém os limites impostos a esse direito sempre se fizeram sentir e ainda cresceram com o tempo. A autoridade das Câmaras Municipais, sob o regime colonial, era bastante restringida pela exigência de obtenção de permissões, de licenças e de autorizações régias

\footnotetext{
${ }^{110}$ Ressalta-se que em uma sociedade onde ainda não se tem a massificação da cultura letrada e nem mesmo de meios de comunicação em massa, os monumentos, como elementos visuais, são fundamentais como demonstração da presença do poder público.

${ }^{111}$ Conforme ressalta Reis Filho (1968:34) as soluções da política de colonização aplicadas ao Brasil davam especial importância à organização municipal. Embora os elementos do sistema social em geral e os elementos político-administrativo em particular fossem no Brasil uma herança formal de elementos similares às tradições portuguesas as configurações que assumiram na Colônia foram particulares. O isolamento das povoações exigia freqüentemente de seus moradores as resoluções de problemas que seriam de competência da Coroa representavam uma autonomia não prevista na legislação já que eram transferidas para a Câmara inúmeras decisões. Todavia, ressalva Fridman (1999:21) que nos séculos XVI e XVII apenas os nobres e os religiosos, os homens bons, tomavam assento no Senado da Câmara. A Câmara não se dedicava aos melhoramentos urbanos, cabendo à população, isto é, foreiros, moradores ou instituições religiosas a responsabilidade pela produção de grande parte dos serviços públicos.
} 
para inúmeras iniciativas locais, sobretudo quando envolviam despesas (ABREU, 1996:156). O autor afirma ainda que

os governantes municipais viviam sob um regime de tutela, sendo abundante os exemplos de obras públicas necessárias muitas das quais urgentes, que eram adiadas ou procrastinadas, com graves prejuízos para a população e para própria administração, por causa da demora de Lisboa em dar solução às consultas enviadas pelos governos locais. Conseqüentemente, muitas soluções provisórias, adotadas enquanto as ordens da metrópole eram esperadas, acabaram por se impor na paisagem. (grifo nosso, ABREU, 1996:157)

Nesse conjunto de obras públicas necessárias insere-se o abastecimento de água da cidade, e a demora no recebimento de recursos influiu no estabelecimento de soluções provisórias e paliativas. Desencadeou também, em normas para a proteção do rio Carioca. Esse era tão importante para o abastecimento da cidade que havia uma legislação especial, de modo a proteger as águas que seriam usadas pela população, bem como a mata que as circundava (NASCIMENTO E SILVA, 2008). Tal procedimento fica evidente na carta de sesmaria concedida pela Câmara a Francisco de Pina em 1611, que impõe uma série de regras a serem cumpridas para a manutenção do rio:

“Com tal que ele não fará prejuízo e água da dita carioca, antes a terá limpa como se requer e não plantará coisa alguma assim de roça como de bananais e legumes e as mais coisas que se plantam. Ao longo do dito Rio ficarão cobertas de mata virgem, o qual não se derrubará, nem se cortará de maneira que esteja sempre de pé, e quando servir-se do dito Rio com sua água assim pra beber e lavar a roupa fará na parte e lugar pra isso" (apud CAVALCANTI, 2004:35).

Apenas o trecho final do rio podia ser usado para a lavagem de roupa e bebedouro de animais. Essa rigorosa legislação de proteção das águas do Carioca merece destaque, pois ao proteger as matas assegurava a vida de afluentes e nascentes. Entretanto, a obra de canalização do Carioca marchou morosamente com o desvio de verbas públicas, drenagem de recursos para outros fins, trabalhos que se arruinaram por problemas de execução, depredações e atos de "sabotagem", projetos equivocados e imperícia dos executores e até um empreiteiro fugiu para não prestar contas do dinheiro recebido. Foram os homens da vereança em mais de uma ocasião, repreendidos pela Metrópole pela aplicação dada a outros fins dos recursos destinados ao prosseguimento das obras do Aqueduto. "Quiseram ainda criar uma taxa especial sobre a aguardente, para esse objetivo; mas a Corte expressamente o proibiu, alegando que as obras tinham consignação certa e abundantíssima" (COARACY, 1965:129). No início dos setecentos, El-Rey promulgou uma ordem peremptória e terminante: suspender de todo as obras até ulterior decisão e aviso. 
Especialmente no século XVIII, quando o absolutismo consagrou a gestão policial do Estado, houve um notável esforço na busca da integração política e econômica das populações e dos territórios de todas as partes dos reinos que não excluía suas colônias. O termo polícia apresentava um significado muito diferente do uso contemporâneo (FOUCAULT, 2006; COARACY, 1965), já que se referia a totalidade dos meios para se acrescentar as forças do Estado. À polícia cabia então cuidar e administrar da melhor forma os recursos naturais e humanos de seus territórios e promover o bem-estar geral dos súditos, especialmente manter a ordem e a disciplina. Esta foi uma era da disciplina e da regulação da sociedade e do espaço, o que resultou no modelo urbano barroco ${ }^{112}$.

No bojo de tais questões, fora criado em Portugal o cargo de Intendente-Geral da Polícia com extensas e múltiplas atribuições pelo Marquês de Pombal por ocasião da reforma dos serviços de administração. Apesar da existência confirmada por Coaracy (1965) no tempo dos vice-reis a presença do Intendente-Geral fez-se notar efetivamente com a transferência da Corte e da administração geral do reino para o Brasil em 1808. O cargo foi então instituído com a plenitude de atribuições que lhe conferia a legislação portuguesa.

O Intendente-Geral da Polícia era autoridade de alta categoria e amplos poderes cujas funções abrangiam a organização e direção dos serviços policiais propriamente ditos, outras funções de administração compreendendo encargos que hoje cabem à magistratura, à prefeitura e ao conselho municipal, à repartição de higiene e até ao Ministério da Agricultura (COARACY, 1965). As ampliadas funções da Intendência restringiam as atribuições da Câmara e compreendiam também os serviços de abastecimento de água.

Em meados do século XIX, as epidemias e as aglomerações urbanas passaram a estar na pauta de intervenções no Rio de Janeiro. Tais fatos puseram em destaque as considerações sobre a teoria miasmática e os ambientes malsãos com uma infinidade de relatórios médicos sobre a gestão das águas e suas emanações consideradas pestíferas colocando novos sujeitos sociais e novas demandas para o planejamento não só do corpo dos indivíduos, mas agora da cidade.

\footnotetext{
112 “Com o urbanismo barroco procurava-se estabelecer padrões de comportamento mais disciplinados, somado à apreciação estética centrada no conceito da perspectiva oriunda do renascimento italiano que exigia uma arrumação dos objetos arquitetônicos e urbanos de modo a que estes se apresentassem diante do observador expondo a lógica do mundo vigente" (FERNANDES, 2008:10). Exemplos de urbanismo barroco são observados na construção de jardins ou parques no coração das cidades, a partir do século XVII. Nesses locais, eram exibidas as práticas, costumes e sociabilidade da Corte e a capacidade do homem em subordinar e disciplinar a natureza, sobretudo pela retificação e geometrização dos canteiros e alamedas, pela poda sistemática de plantas e árvores Além disso, eram perseguidas preocupações relacionadas com o abastecimento de víveres e água, com a saúde e a higiene pública, com as atividades insalubres e outros temas de interesse do Estado policial (FERNANDES, 2008).
} 


\section{Da cidade à metrópole - de problema à questão das águas}

A primeira década do século XX representa, para a cidade do Rio de Janeiro, uma época de grandes transformações motivadas, sobretudo pela necessidade de adequar a forma urbana às necessidades radicais de criação, concentração e acumulação do capital. Devido o rápido crescimento da economia brasileira, a intensificação das atividades exportadoras e a integração do país no contexto capitalista internacional, exige-se da organização espacial reflexos dessa nova organização social (ABREU, 2008; ROCHA, 1996). Houve um grande empenho social, político e econômico na busca da realização do projeto de renovação e higiene urbana, no qual as noções de progresso, civilização e modernidade eram pressupostos basilares (ROCHA, 1996).

Conjuntamente, o saneamento da capital constituía-se, naquele momento, numa preocupação nacional. A cidade convivia com sérios problemas de infra-estrutura agravados pelo congestionamento cada vez maior de sua malha urbana ${ }^{113}$.

A eletrificação integra o projeto de embelezamento e modernização urbana, através do qual o poder público, representando interesses do capital internacional, das elites e dos setores médios, impondo um modelo de civilização que tornava ainda mais visíveis as contradições de uma sociedade profundamente excludente ${ }^{114}$ (ROCHA, 1996).

A modernização urbana foi, em grande medida, financiada por empresas estrangeiras, cuja entrada no Brasil era facilitada por uma conjuntura internacional de expansão de capitais e pela política desenvolvida pelo governo brasileiro no período. Os promoters, agentes

\footnotetext{
${ }^{113}$ Fernandes (2008) identifica na cidade do Rio de Janeiro um quadro de crise de moradia popular que se manifestou com particular virulência com a Revolta de Vacina, em 1904, no meio da primeira reforma urbana da cidade na era industrial. "Embora esta rebelião tenha muitos ingredientes, inclusive a sua instrumentalização para um golpe de Estado por setores militares e outros grupos, não houve duvida entre os contemporâneos que seu combustível mais potente foi justamente a crise da habitação, exacerbada pela destruição de parte dos bairros centrais onde ainda vivia a maior parte das classes populares. A percepção da ameaça da situação explosiva que representava a crise da moradia popular mobilizou as forças políticas e o próprio governo foi obrigado a nomear uma comissão para estudar a questão". Prevalece, todavia, a posição liberal de que o mercado deveria resolver a questão com o discreto apoio do governo, alguns de seus membros, como o inspetor da Diretoria Municipal de Obras, Everardo Backeuser, propuseram "a intervenção franca, positiva e declarada do Estado, emprestando capitais ou construindo ele mesmo as casas" necessárias em locais bem comunicados da cidade. §"Backeuser enxergava na crise uma questão social potencialmente explosiva, cujo remédio não adviria do receituário liberal nem das leis 'naturais' da economia". (BENCHIMOL, 1992: 293; FERNANDES, 2008).

${ }^{114}$ Para que o projeto da holding Light fosse viabilizado, os capitalistas buscaram neutralizar toda uma legislação contrária à formação de monopólios na capital ao mesmo tempo que dedicavam-se a um complexo trabalho de captação de recursos no mercado financeiro internacional, obtendo apoio da National Trust e do Bank of Commerce, além de outros grandes investidores. Através de obtenção de controle acionário, compra integral de ativo e aquisição indireta, o grupo adquire o controle da produção e da distribuição de energia elétrica, além de maior parte das concessões de transportes ferro carris da capital, visando sua eletrificação, contando com o apoio incondicional dos poderes públicos.
} 
financeiros de empresas estrangeiras, tiveram papel fundamental neste processo em que se misturam barganhas políticas e econômicas ${ }^{115}$.

Assim em conjunto às grandes estiagens do início do século XX, a administração de serviço público de sistema de abastecimento de água do Rio de Janeiro resolveu abandonar os estudos de reforço de suprimento de pequeno porte, voltando-se para soluções de grande porte e apresentou dois projetos: o sistema Ribeirão das Lajes e a captação de águas dos rios Santana e Paraíba do Sul. O primeiro foi executado, mas o segundo teve que ser alterado uma vez que se chocava com os interesses da concessionária do serviço de energia elétrica, a Light, que produzia energia através da transposição da Serra do Mar, das águas do rio Paraíba do Sul, captando em Santa Cecília bem como, dos reservatórios de Santa Cecília, Santana e Vigário $^{116}$ (BARBOSA e WALCACER, 2004; ANA, 2007).

Em paralelo a adução das águas construía-se inúmeros reservatórios no controle da distribuição, porém Silva (1965) percebe que o Departamento de Água não conseguia equilibrar o abastecimento, pois as obras reclamadas vieram sempre com grande atraso, cobrindo sempre os déficits assinalados, Depois do reforço atingido pela construção da estação Elevatória de Acari em 1933 e a breve estabilização no sistema e da promulgação do Código de Águas $(1934)^{117}$, a cidade do Rio de Janeiro deixou de ter o seu sistema de

${ }^{115}$ O capitalismo monopolista no limiar do século XX, retoma os projetos, agora, (neo)coloniais sobre a América Latina para a especulação e expansão do sistema, e necessariamente consubstanciar a colonialidade do poder (QUIJANO, 2005) sobre a região. Segundo Rocha (1996), os capitais investidos em empresas privadas, nacionais e estrangeiras, em funcionamento na região, ou eram emprestados aos governos latino-americanos, objetivando juros, lucros e royalties nas transações. Outros benefícios decorrentes de concessões comerciais, financeiras e institucionais (inclusive de caráter fiscal) foram almejados e amplamente conseguidos. A distribuição dos recursos, porém não eram alocados de modo uniforme, aplicados em produção - e especialmente na indústria extrativa mineral -, quanto na comercialização e na intermediação financeira. $\mathrm{O}$ montante maior destes recursos foi aplicado, essencialmente no estabelecimento de um novo fluxo de circulação de mercadorias. O processo de urbanização latino-americano da virada do século XX desempenhou papel estratégico na reprodução ampliada do capital. Sua dimensão, no entanto, longe de se esgotar nisto, manifesta-se nas adaptações, resistências e contradições vividas pela sociedade do período (ABREU, 2008; BULHÕES E REIS, 1980). Para Fernandes (2008) "as reformas urbanas denunciaram os limites dos postulados liberais na gestão da cidade e diante da crise política, social e ambiental foi requerida a intervenção do Estado para a remodelação dos centros das cidades, uma verdadeira reconquista da centralidade pela burguesia e pelo Estado, através da demolição de bairros e zonas populares centrais e o conseqüente deslocamento destes grupos sociais para localizações periféricas e suburbanas. A suburbanização do proletariado e a edificação sobre a velha cidade de novos centros para os negócios, residência e atividades das classes superiores e o Estado são os aspectos mais marcantes deste processo." O Rio de Janeiro da Belle epoque, é uma das cidades latino-americanas onde a elite dirigente melhor incorporou a urbanização como uma necessidade premente de uma sociedade que precisava "civilizar-se". As reformas, que em poucos anos redefiniram funções para as áreas centrais da cidade, criaram condições para um novo ordenamento espacial com o surgimento de novas zonas de elite na parte sul.

${ }^{116}$ A energia elétrica desses subsistemas é gerada primeiramente nas Usinas de Fontes e Nilo Peçanha. A seguir, as águas, já no talvegue do Ribeirão das Lajes, formam o reservatório de Ponte Coberta, gerando novamente energia na Usina de Pereira Passos.

117 “O Código de Águas promulgado em 1934 pelo Governo Federal pelo Governo Federal regulamentou a fixação de tarifas cobradas pelas concessionárias, a racionalização dos recursos hídricos do país e o reequilíbrio da política de outorga de concessão para a produção e distribuição de energia elétrica entrando em conflito principalmente com a Light. Determinou também a limitação do lucro da concessionária ao nível de $10 \%$ de 
abastecimento de águas sujeito a regimes sazonais de vazão, que se dividem nas chamadas "grandes adutoras" e "pequenas adutoras". Estes mananciais de pequeno porte dentro dos limites do atual município do Rio de Janeiro, que são hoje cerca de 40 sistemas de captação superficial de água de boa qualidade, necessitam somente de desinfecção e são utilizados para atender áreas urbanas em cotas elevadas, próximas das captações, devido às dificuldades em atendê-los pelos sistemas principais (BARBOSA e WALCACER, 2004; ANA; 2007). Isto só foi possível com a construção, no ano de 1940, da $1^{\text {a }}$ Adutora de Ribeirão das Lajes e, em 1949, da $2^{\text {a }}$ Adutora da "Usina de Fontes Velhas" da Light, o que oferecia uma indispensável garantia de abastecimento perene e ininterrupto. Este sistema proporcionou, a partir de 1949, uma vazão de 5100 litros por segundo a mais para o Rio de Janeiro.

Durante o mandato do prefeito Hildebrando de Góes, o engenheiro José Franco Henriques, Diretor do Departamento de Águas, sugeriu a construção de uma terceira adutora de grande diâmetro, com capacidade para 225 milhões de litros por dia, a Guandu-Leblon, utilizando as águas do rio Guandu, já previstas pelo engenheiro Henrique de Novaes. No início da década de 50, o contínuo crescimento das demandas de água da cidade do Rio de Janeiro, levou à captação das águas do rio Guandu, já acrescido de águas dos rios Paraíba, Piraí, Ribeirão das Lajes, Poços e Santana. A cidade ampliava a demanda por água e sua transformação em metrópole. Não se olvida que nesse momento o sistema hidrelétrico detinha imenso poder político sobre a questão das águas, visto que para o processo de industrialização se realizar a energia hidrelétrica é condição fundante.

Retomemos o contexto do momento pós-reforma Pereira Passos, a fim de explicitar alguns dos movimentos da expansão metropolitana, ainda em potência, mas que logo se realiza. Para Abreu (2008):

[...] o período 1906-1930 caracterizou-se pela notável expansão do tecido urbano do Rio de Janeiro, processo esse que se efetuou de maneira distinta no que se refere a dois grandes vetores de crescimento da cidade. De um lado, a ocupação das zonas sul e norte pelas classes médias e altas intensificou-se, e foi comandada, em grande parte, pelo Estado e pelas companhias concessionárias de serviços públicos. De outro, o subúrbio carioca cada vez mais se solidificou como local de residência do proletariado, que para aí se dirigiu em números crescentes. Ao contrário da área nobre, a ocupação suburbana se realizou praticamente sem qualquer apoio do Estado ou das concessionárias de serviço público, resultando daí

capital investido avaliado segundo o principio histórico, não há duvidas eu tais fatos atrasaram o processo de promulgação do Código pelo privilégio que a Light deliberava no serviço de energia hidrelétrica em detrimento ao abastecimento de água. Uma forte tendência ao nacionalismo e a centralização no âmbito federal de decisões na área de recursos estratégicos, cujo ápice se dá com a promulgação do Código de Águas em 1934, era latente. Portanto, a Light precisava formar uma imagem mais positiva junto à população, de forma a ter algum respaldo político, e, para tanto, empenhou-se num projeto de publicidade explícito, embora tenha mantido as práticas de manipulação" (ROCHA, 1996). 
uma paisagem caracterizada principalmente pela ausência de benefícios urbanísticos (ABREU, 2008:82).

A Revolução de 1930 acompanha o novo regime de acumulação que estava sendo gerado nas matrizes do capitalismo, o Estado brasileiro assume uma feição crescentemente antiliberal, intervindo decididamente no ordenamento do território e do urbano e demais aspectos da vida econômica e social (FERNANDES, 2008).

O Rio de Janeiro foi profundamente marcado nos 40 e 50 pelos conjuntos habitacionais produzidos pelo Estado, não só pela área construída, pelos bairros e zonas ocupadas, "mas, sobretudo pelos seus programas inovadores, onde se associavam edifícios de moradia com equipamentos sociais e recreativos, áreas verdes e de lazer" Fernandes (2008), integrados em sistemas viários e de transportes novos e remodelados, como a eletrificação de parte do sistema ferroviário suburbanos em 1937, ou a construção de modernas rodovias como as avenidas Brasil (1946), e as estradas Rio-São Paulo e Rio-Belo Horizonte nos anos 40.

Esse momento também caracteriza uma ocupação mais espraiada e intensa nas favelas pela cidade devido a forte migração para a cidade, pelo deslocamento industrial para os subúrbios e o desenvolvimento da zona sul. Assim, apesar de uma atuação no controle urbanístico da dita cidade formal as favelas não tiveram suas ocupações assaz comprometidas, pois, o forte fluxo migratório era um fator impeditivo para amplo controle coercitivo, a mãode-obra barata e próxima dos locais de trabalho atendia as necessidades da indústria, do comercio e da burguesia em geral ávida no acúmulo de capital, além de ocuparem terrenos públicos e que não eram objetivados pelas ações das empresas imobiliárias pelo seu caráter acidentado e de difícil acesso.

O crescimento populacional das áreas periféricas foi outra característica do período ligado a fatores determinantes tais como as obras de saneamento realizado pelo Departamento Nacional de Obras de Saneamento (DNOS), a eletrificação da Central do Brasil, a partir de 1935, a instituição da tarifa ferroviária única no Grande Rio e a abertura da Avenida Brasil, (ABREU, 2008) observa-se então um amplo crescimento demográfico e farta ampliação das contradições nesse espraiamento.

Entre 1946-1964 verifica-se o aumento do valor do solo, a distância cada vez maior que separava os locais de emprego dos novos loteamentos, congelamento de aluguéis, acarretou uma crise habitacional generalizada sobre tudo pelas camadas mais pobres, ocasionando a multiplicação da população favelada, inúmeras em áreas nobres da cidade. A década de 1950 se desenvolve ampla expansão física da cidade (e da adensada metrópole 
carioca) sobre a estruturação do espaço não acompanhada de infra-estrutura básica, resultando a formação de uma periferia metropolitana extremamente carente de infra-estrutura e serviços urbanos, o crescente aumento das distâncias entre o centro da cidade e da metrópole e as áreas residenciais suburbanas ocasionando subcentros funcionais e a necessidade de subsidiar o capital industrial em fuga da cidade do Rio de Janeiro na década de 60 ocasionando ampla política de remoção de favelas das áreas próximas a Avenida Brasil e para a expansão do capital financeiro-imobiliário na Zona Sul. O processo de divisão social do trabalho e da hierarquização das classes na cidade irá inclusive se apresentar na questão do abastecimento de água e a precariedade do serviço principalmente nas favelas e nas periferias da cidade e da metrópole.

\section{Metáforas da mundialização do capital: o abastecimento de água na cidade do Rio de} Janeiro.

Concordamos com Abreu (2008) acerca de sua interpretação sob o papel fundamental que o autoritarismo (no caso da ditadura civil-militar) terá, nesse processo de retomada de uma tendência de estratificação sócio-espacial da cidade ainda mais aviltante. Pois, não mais dependente do julgamento popular via eleições livres, o Estado intensifica a sua ação discriminatória sobre o espaço, privilegiando claramente as áreas mais ricas da cidade, especialmente o centro e a Zona Sul. Além de preparar a área da Barra da Tijuca ${ }^{118}$, já na década de 60 em associação com o capital privado para especulação imobiliária, oferecendo um conjunto de equipamentos coletivos fundamentais, investimentos estes, aplicados em detrimento das áreas mais pauperizadas da cidade.

Assim, neste período, o Estado tem um papel ainda mais radicalizado de articulação com as classes dominantes e de estratificação sócio-espacial garantindo seus interesses e investimentos e mantendo o privilégio na acessibilidade aos equipamentos coletivos tal como o abastecimento de água a algumas áreas da cidade. Esse período caracteriza-se inicialmente pela implementação do Plano Doxiadis (1963-1965) que foi elaborado pelo escritório grego "Doxiates and Associates" quando a cidade era ainda o Estado da Guanabara, refletindo a ideologia desenvolvimentista, e propondo-se a preparar a cidade para o ano 2000, esse plano pretendia remodelar a cidade a partir de obras que afetariam (como afetaram) principalmente

\footnotetext{
${ }^{118}$ As características da Barra da Tijuca com relação à concentração da propriedade da terra e à fixação por parte do Estado de normas claras e estáveis de uso do solo a transformaram numa área privilegiada de ação para a grande incorporação pela possibilidade de auferir elevados sobrelucros de antecipação (CARDOSO, 1989). O que o perfil de investimentos em infra-estrutura nos mostra é que devemos acrescentar a estas vantagens os maiores investimentos públicos em equipamentos coletivos de saneamento de toda a metrópole.
} 
as populações mais pobres (ABREU, 2008). Esse plano realizou uma série de cirurgias urbanas resultando num processo sistemático de ações para a erradicação de favelas com autoritárias remoções e deposições de moradores em espaços observados pelo poder público como receptáculos de populações pauperizadas. Espaços com a ausência de infra-estrutura e equipamentos coletivos.

O governo de Carlos Lacerda é emblemático neste processo sendo todo o conjunto de administradores posteriores só vieram reafirmar a ação preferencial do Estado nas áreas mais ricas da cidade. Durante sua gestão (1960-1965) a política de remoção de favelas é colocada em prática conjuntamente à urbanização de algumas favelas. Essas duas perspectivas representam a estrutura central do plano de reforma urbana do Governo do Estado da Guanabara. Tascher (1986) argumenta que uma das características centrais é a limpeza da zona sul, sobretudo os aglomerados no entorno da Lagoa Rodrigo de Freitas, sendo que sua eliminação significaria a liberação de terrenos que já concorriam com terras desejadas para especulação imobiliária pelas classes médias e altas.

A construção das Adutoras no Rio Guandu são partes do pacote de ações apresentadas como soluções e de modernização no sistema No governo de Carlos Lacerda inaugura-se a Segunda Adutora do Guandu, obra retratada como a grande "solução definitiva" para os problemas de abastecimento de água na cidade do Rio de Janeiro, o que de fato ocorreu foi a canalização das melhorias no sistema para o desenvolvimento de áreas já privilegiadas da cidade e para engendrar o processo de urbanização corporativa da área da Barra da Tijuca. Porém as áreas periféricas ainda sofriam os efeitos da sazonalidade ou da inexistência no abastecimento.

Visando garantir os recursos necessários à implantação do programa de expansão do sistema de abastecimento de água, o governo de Carlos Lacerda promoveu uma revisão da tarifa de água e recorreu ao financiamento externo (ABREU, 2008).

Assim, em maio de 1962 obteve um empréstimo no valor de 24 milhões de dólares, posteriormente acrescido de outro no valor de 12 milhões de dólares, do Banco Interamericano de Desenvolvimento (BID). Esse empréstimo foi aplicado, quase na totalidade, no programa de abastecimento de água, que abrangia obras de adução e de distribuição. Ainda no governo Lacerda foram concluídas as obras das adutoras de Paquetá e de Jacques Acari e, em 1961, teve início a construção da adutora do Guandu.

Compreendemos também que às empresas estatais passam também por processo de estruturação para a lógica desenvolvimentista. Por exemplo, em 1957, foi criada a Superintendência de Urbanização e Saneamento (SURSAN) e, em 1961, ocorreu um caos no 
abastecimento da cidade. Neste mesmo ano, o Departamento de Águas foi incorporado a SURSAN. Várias obras de construção de reservatórios foram feitas com este recurso e criouse a Companhia Estadual de Águas da Guanabara (Cedag).

O Governo do Estado concedeu à Cedag, a partir de 1966, o direito de cobrar as contas de água. A Cedag remodelou seus reservatórios, substituiu tubulações, montou seu cadastro próprio de consumidores, equipou-se com computadores da mais alta tecnologia para aquele momento e iniciou a implantação da telemetria em seu controle do sistema adutor. Entre 1966 e 1975, foram realizados muitos investimentos, desde os da City Improvements, na metade do século passado, até os da Esag (Companhia de Esgotos da Guanabara), Cedag e Sanerj (Companhia de Saneamento do Estado do Rio de Janeiro), no início dos anos 1970, passando pela SURSAN e pela Inspetoria de Águas e Esgotos - IAE (BARBOSA e WALCACER, 2004). Dentro dessa estrutura está como estruturador as políticas do PLANASA e do BNH ${ }^{119}$.

A partir dos fatores políticos relacionados a fusão do antigo estado do Rio de Janeiro e da Guanabara e de fatores econômicos possibilitados pelos empréstimos externos, no ano de 1975, a Companhia Estadual é criada, concentrando as funções de todos os órgãos existentes anteriormente e centralizando a gestão dessas redes de abastecimento na cidade do Rio de Janeiro numa atmosfera de autoritarismo e repressões. Neste mesmo ano, a CEDAE (Companhia de Águas e Esgotos do Rio de Janeiro) ocupa lugar de destaque sendo a empresa mais avançada de saneamento do Brasil (MARQUES, 1993; 1995).

Paralelamente, essa empresa, tomada como modelo de gestão e eficiência hídrica, negligenciava o acesso à água às áreas periféricas da cidade. Licia Valladares (1980) assim descrevia as primeiras semanas dos removidos de favelas para conjuntos habitacionais tais como em Vila Kennedy na Zona Oeste da cidade do Rio de Janeiro:

[...] o início da ocupação era muito movimentado, os escritórios locais da COHAB não bastavam para atender às reclamações e queixas de toda espécie. Ora a água não saía das torneiras, ora o reboco das paredes apresentava defeitos, as chaves de entrada eram todas iguais ou ainda a luz não estava ligada, etc. [...] queixavam-se do tamanho da habitação ou ainda de sua localização (VALLADARES, 1980: 64).

\footnotetext{
${ }^{119}$ Segundo Arretche (1998) o Plano Nacional de Saneamento (PLANASA) foi criado em 1968, instituído em 1969, porém só começou a funcionar dois anos depois, quando passou a destinar recursos para os estados criarem suas próprias companhias de saneamento. O PLANASA estava substanciado no Sistema Nacional de Saneamento onde estava inseridos, conforme expõe Arretche o Banco Nacional da Habitação (extinto em 1986) e o Fundo de Garantia do Tempo de Serviço (FGTS), a principal fonte de recursos do PLANASA. "Para isso, instituiu o Sistema Financeiro de Saneamento (SFS), gerido pelo Banco Nacional da Habitação (BNH). Para obter o financiamento, cada estado da federação deveria criar, com base em seus recursos orçamentários, um Fundo de Financiamento para Águas e Esgotos (FAE) e uma companhia estadual de saneamento". O Planasa foi abandonado como política pública em 1990, apesar de completamente desestruturado a partir de meados da década de 1980.
} 
A população pauperizada excluída dos serviços de infra-estrutura básica articula suas demandas a partir de um questionamento acerca da inexistência de equipamentos coletivos e a necessidade de expansão a bairros periféricos. Depois de um período de refluxo dos movimentos sócio-territoriais urbanos durante o momento de radicalização da estratificação sócio-espacial marcado profundamente pelo autoritarismo.

Nesse contexto, Pedro Jacobi (1986) afirma que, na conjuntura de crise do autoritarismo, a ascensão dos movimentos sociais e das organizações políticas de oposição vão configurar e consolidar espaços de articulação de diferentes formas de organização de moradores na luta pela cidade como direito.

Assim, ação do Estado não só legitima as demandas dos movimentos sociais urbanos, mas "joga" com o grau de mobilização para conseguir a liberação das verbas. A lógica da ação coletiva assume uma crescente feição dialógica onde os dois pólos se transformam no processo, possibilitando algumas conquistas e intensos embates.

Conforme afirmações de Lago (1990) na segunda metade da década de 1970 teve início à crise de produção de alternativas habitacionais para a população pobre da cidade. Fatos como o processo inflacionário, acompanhado do enorme achatamento, inviabilizava a produção de loteamentos populares e, posteriormente, de conjuntos habitacionais, frente à incapacidade dos segmentos de baixa renda assumirem prestações reajustadas. Nesse quadro estabelece-se uma crise nos pagamentos e o estopim dos loteamentos na Zona Oeste por ser lugar de loteamentos e conjuntos passa a ser palco de conflitos e lutas na intensificação de ocupações por equipamentos urbanos coletivos com as associações de moradores em movimento reivindicando direitos frente ao Estado e aos loteadores.

Existem hoje evidências de que este quadro sofreu alterações a partir do final dos anos 70. Marques (1993), estudando os contratos para execução de serviços pela CEDAE, a partir de meados da década de 70, mostrou um crescimento dos investimentos nas zonas mais pobres (periferias e favelas), que passaram a ser equivalentes aos realizados nas áreas mais valorizadas.

Lago (1998) argumenta que essa mudança no padrão histórico de alocação dos investimentos, na década de 80 , reverteu-se em melhoria nas condições de vida das populações pobres, pois um conjunto de fatores levou ao redirecionamento, mesmo que parcial, dos investimentos. Sob as demandas que emergem, a partir de formas de reivindicações, dos movimentos populares e que ganham legitimidade com o retorno das eleições diretas, mas também com as demandas dos novos agentes econômicos responsáveis pela dinamização de áreas específicas nas periferias. 
Mesmo com a profunda desigualdade de acesso à infra-estrutura básica ainda presente em 1991, a década de 80 marcou uma melhoria nas condições de abastecimento de água na metrópole do Rio de Janeiro, reduzindo as diferenciações espaciais (LAGO, 1998; MARQUES, 1993). A inversão do padrão de alocação espacial dos investimentos públicos em saneamento garantiu maior expansão dos serviços para determinadas áreas da periferia.

Todavia, as condições de abastecimento de águas permaneceram altamente desiguais entre as diferentes camadas sociais, principalmente na periferia, o que nos faz supor que os investimentos públicos nessas áreas tendem a responder, prioritariamente, às novas demandas tanto do setor produtivo em expansão, entre eles o setor imobiliário, quanto dos segmentos de mais alta renda, tendem a se localizar em áreas restritas.

Sob outro preâmbulo Luciana Corrêa do Lago (1998) afirma ainda que a retração dos investimentos públicos no urbano e a entrada dos programas financiados pelas grandes agências internacionais que, no caso do Rio de Janeiro, tiveram papel decisivo na distribuição dos recursos para infra-estrutura básica com as novas perspectivas acerca da gestão dos recursos hídricos e do saneamento básico. Nesse contexto, começam a surgir os especialistas com o discurso acerca da suposta eficiência do capital privado sobre a ineficiência do Estado.

Estes já apontam para um novo período que irá se consolidar principalmente a partir do início da década de 90, marcado pela do retirada do Estado da prestação de inúmeros serviços em crise abrindo nichos para as empresas seguindo a cartilha do Consenso de Washington da eliminação de reservas de mercados para mercadorias e serviços e alterando as legislações de águas não é a toa a ampla repercussão dos discursos de raridade e escassez das águas e o uníssono de metáforas encaradas como puro desafio para salvar a humanidade da natureza indomável e/ou preservá-la intocável para gerações futuras (lê-se para as grandes corporações transnacionais presentes-passadas-e-futuras na verdade), são elas desregulamentação, flexibilização, democratização, participação, liberação de mercado, educação ambiental, desenvolvimento sustentável, sustentabilidade, meio ambiente, e infindáveis outras com o mesmo princípio: ampliar os nichos de mercado sobre a infraestrutura e os equipamentos coletivos urbanos.

Desse modo ocorrem as correlações entre os discursos e as formulações ideológicas concernentes "à crise da água" e à "descoberta da escassez dos recursos hídricos", pois, no início da década de 90 surgem no cenário os gestores "especialistas em recursos hídricos" arraigados desses recursos.

Nesse momento acentua-se o discurso da escassez da água em escala global. O fato de agora se estruturar um discurso pretensamente científico a partir da argumentação do uso 
racional dos recursos por meio de uma gestão técnica aponta os novos protagonistas da gestão dos recursos hídricos: os gestores, especialistas com formação técnica e científica.

A demanda da água estrutura-se como um negócio na lógica da cidade-mercadoria. Mais que uma infra-estrutura que propicia a cidadania, o abastecimento de água insere-se na lógica neoliberal como algo inexoravelmente financeiro, a água como bem econômico indiscutivelmente uma commodities com lobistas de empresas transnacionais e as ocupações formais nas áreas privilegiadas e pagantes detentoras do privilégio.

Com a privatização dos recursos hídricos ou, como no caso da cidade do Rio de Janeiro, com o chamado "choque de gestão" em que apesar de pública a empresa adquire todas as características de gestão e administração privada, ocorre uma substituição dos protagonistas na gestão desses recursos. Entretanto com esse instrumento em mãos o empresariado detém um dos instrumentos de estratificação sócio-espacial que é o abastecimento dos recursos hídricos estabelecendo novas lógicas no uso do território da cidade, fenômenos esse bastante recente que merece muita atenção.

Se a infra-estrutura e os equipamentos coletivos constituem mercadorias, se as políticas habitacionais são centralizadoras e elitistas, e se por outro lado o salário é mantido em um nível abaixo daquele que permitiria a compra dos bens, as necessidades são em grande parte supridas pela prática da autoconstrução ou não são supridas (MARICATO, 1979). A ampla financeirização da vida, exemplarmente nas empresas de créditos, da política habitacional entregue ao capital financeiro-imobiliário, dentre outros processos apresentam-se nesse contexto como se fossem "sanar", "resolver" e "solucionar" "todos" os problemas. Na verdade, o Estado posterga e se desonera dos fragmentos do espaço da reprodução da classe trabalhadora, especialmente as favelas e as periferias. E investe-se continuamente na reprodução do capital continuamente e de modo cada vez mais acelerado. As crises demonstram um momento de freio, porém também são uma nova possibilidade de expansão por isso uma das características centrais do modo de produção capitalista é seu poder de mimetismo em tempos mais liberais ou de mais intervencionismo estatal. A expansão do capitalismo se dá introduzindo relações novas no arcaico e reproduzindo relações arcaicas no novo, como bem relembra-nos Francisco de Oliveira.

\section{Considerações Finais do Apêndice}

Com o estudo da problemática das "cidades" e das "águas" buscamos compreender as relações sociais que se estabelecem por meio do trabalho humano, relações metabólicas entre sociedade e natureza. Sobre esse debate muitos caminhos podem ser seguidos. Nosso foco foi 
analisar à luz das imbricações entre espaço-tempo, no âmbito da Geografia Histórica (ABREU, 1996; 2008), da Geografia Urbana Retrospectiva (AZEVEDO, 1957), ou no nosso entendimento na busca pela compreensão da construção geográfica da sociedade (baseados em MOREIRA, 1994, 2007; LACOSTE, 1988) como uma proposta de teoria e método de análise. Não constitui tarefa fácil discutir o processo de urbanização, a materialização social da cidade, os múltiplos conteúdos do urbano, a dinâmica de acumulação capitalista do espaço urbano e os conteúdos de uma política urbanizadora sob o enfoque da apropriação das águas, ou mais especificamente do abastecimento de água. Identificamos obras que tangenciam as discussões, ou que quando focalizam na temática abordam um período determinado. Outras obras analisam apenas a forma dos objetos ligados ao abastecimento (trabalhos sobre os chafarizes, sobre o aqueduto, sobre encanamentos, dentre outros), ou em determinadas etapas da economia política do sistema de abastecimento de água (seja na captação e reservação ou na distribuição ou no armazenamento ou no consumo ou na gestão das águas) às vezes analisando mais de uma etapa, mas faltando sempre uma visão mais completa com foco na urbanização do território e na conflitividade que esse processo enseja e desencadeia nas relações sociais.

Estimulados pelas proposições de Custódio (2008) expomos embrionariamente essas considerações em Prieto (2008a) e Prieto (2008b). Entretanto, só o aprofundamento da metodologia possibilitaria a construção de uma teoria (geográfica) para a urbanização do Rio de Janeiro na longa duração que significa um projeto de fôlego que esse trabalho almeja contribuir. Encerramos com a esperança de ter movido o moinho de idéias, leituras e análises.

\section{Referências do Apêndice B}

ABREU, M. de A. O estudo geográfico da cidade no Brasil: evolução e avaliação (contribuição à história do pensamento geográfico brasileiro). In: CARLOS, Ana Fani A. (org.). Os caminhos de reflexão sobre a cidade e o urbano. São Paulo, Edusp, p. 199-322. (Publicado também na Revista Brasileira de Geografia, v. 56, n. 114, jan-dez 1994. p. 21-122)

ABREU, M. de A. A cidade, a montanha e a floresta. In: (org.). Natureza e sociedade no Rio de Janeiro. Rio de Janeiro: Prefeitura da Cidade do Rio de Janeiro, 1992. P. 54-103.

ABREU, M. de A. A evolução urbana do Rio de Janeiro. Rio de Janeiro, IPP, 2008.

ABREU, M. de A. Pensando a cidade no Brasil do passado. In: CASTRO, I. E. de.; GOMES, P. C. da C. CORRÊA, R. L. (org.). Brasil: questões atuais da reorganização do território. Rio de Janeiro: Bertrand Brasil, 1996. P. 145-184.

ABREU, M. de A. O meio ambiente e a metrópole. In: ABREU, M. A. (org.). Natureza e sociedade no Rio de Janeiro. Rio de Janeiro: Biblioteca Carioca, 1992. 
Agência Nacional das Águas - ANA. A História do Uso da água no Brasil: Do descobrimento até o Século XX. Brasília: ANA, versão preliminar, 2007.

ALMEIDA, A. Cidade, água e poder: o aqueduto da Carioca e o chafariz do Largo do Paço. In: Anais do XII Encontro Regional de História (ANPUH - RJ), Rio de Janeiro, 2006.

ALMEIDA, A. O aqueduto da Carioca: paisagem da urbanidade. In: TERRA, Carlos G. e ANDRADE, R. O. (orgs.) Paisagens Culturais. $3^{\circ}$ Seminário de Paisagismo Sul-Americano. Vol. 2. Interfaces entre tempo e espaço na construção da paisagem sul-americana. Rio de Janeiro: EBA/UFRJ, 2008.

ALVAREZ, J. M. S. No meio do caminho tinha um vulto: biografia transversa do juiz especular que foi o pai de Antonio José da Silva, o judeu. Espéculo (Madrid), Madrid, v. 31, 2005

AMORIM, Paulo Henrique. Ambientes e representações: a construção de epistémes nos espaços e ex-passos do pensar geográfico. São Paulo: Anais do XV Encontro Nacional de Geógrafos, 2008.

ARAÚJO, R. de. As cidades da Amazônia no século XVIII - Belém, Macapá e Marzagão. Porto: FAUP, 1998

AZEVEDO, A. de. Vilas e cidades do Brasil colonial. Anais da AGB, v. IX, tomo I, 19541955. São Paulo: AGB, 1957. 76p.

BARBOSA, F.; WALCACER, F. C. Aspectos do Sistema de Abastecimento de Água do Estado do Rio de Janeiro - O Rio Guandu e a Gestão dos Recursos Hídricos. Rio de Janeiro: FGV, 2004.

BENCHIMOL, J. L. A reeestruturação dos sistemas de água e esgoto no Rio de Janeiro. In: BENCHIMOL, J. L. Pereira Passos: um Haussmann tropical - a renovação urbana do século XX. Rio de Janeiro: Biblioteca Carioca, 1992.

BENCHIMOL, J. L. A cidade escravista. In: Pereira Passos: um Haussmann tropical: A renovação urbana da cidade do Rio de Janeiro no início do século XX. Rio de Janeiro: Secretaria Municipal de Cultura, Turismo e Esportes, Departamento Geral de Documentação e Informação Cultural, Divisão de Editoração, 1992. P. 21-39.

BERNARDES, L. M. C. Expansão do espaço urbano no Rio de Janeiro. Revista Brasileira de Geografia: Rio de Janeiro, julho - setembro de 1961.

BERNARDES, L. M. C. Função defensiva do Rio de Janeiro e seu sítio original. Boletim Carioca de Geografia: Rio de Janeiro, v. 13, n. 1-2, p. 92-97, 1960.

BERNARDES, L. M. C. Evolução da paisagem urbana do Rio de Janeiro até o início do século XX. In: ASSOCIAÇAO DOS GEOGRAFOS BRASILEIROS (Seção Regional do Rio de Janeiro). Aspectos da geografia carioca. Rio de Janeiro, CNG/IBGE, 1962. P. 46-64.

BERNARDES, N. Notas sobre a ocupação humana da montanha no estado da Guanabara. In: ASSOCIAÇAO DOS GEOGRAFOS BRASILEIROS (Seção Regional do Rio de Janeiro). Aspectos da geografia carioca. Rio de Janeiro, CNG/IBGE, 1962. P. 188-210.

BICALHO, Maria Fernanda. A cidade e o império: o Rio de Janeiro no século XVIII. Rio de Janeiro: Civilização Brasileira, 2003.

BLAY, Eva. Crise urbana ou crise de reprodução do capital? In: BLAY, Eva. A luta pelo espaço: textos de sociologia urbana. Petrópolis: Vozes, 1979. 
BRANDAO, R. P. As Relações Étnicas na Conquista da Guanabara. In: XXIII Simpósio Nacional de História: Guerra e Paz, 2005, Londrina - PR. Anais XXIII Simpósio Nacional de História: história: guerra e paz. Londrina : Editorial Mídia, 2005.

BRENNA, Giovanna Del. Modelo alternativo ou variante? Reflexões sobre a "regularidade relativa" de algumas cidades de fundação portuguesa. In: Anais do IV Seminário da história da cidade e do urbanismo. Vol 1, p. 415-418. Rio de Janeiro, UFRJ/PROURB, 1996.

BRITTO, A. L. N. P. A Regulação dos serviços de saneamento no Brasil: perspectiva histórica, contexto atual e novas exigências de uma regulação pública. In: IX Encontro Nacional da ANPUR, 2001, Rio de Janeiro. Anais... Rio de Janeiro: ANPUR, 2001. v. 3. p. 1080-1093.

BRUNO, Ernani Silva. A água nas velhas cidades do Brasil. Jornal, São Paulo, 15 out. 1947.

BUENO, Beatriz Piccoloto Siqueira. Desenho e desígnio - o Brasil dos engenheiros militares (1500 -1822). São Paulo: FAU/USP, 2001 (Tese de doutorado)

BUENO, B. P. S. Decifrando mapas: sobre o conceito de território e suas vinculações com a cartografia. Anais do Museu Paulista, São Paulo, v. 12, p. 193-234, 2004

BULHÕES, A.M. de O. e REIS, A. A assistência médica no Rio de Janeiro: uma contribuição para sua história no período 1870-1945. Rio de Janeiro: CMSB/UCAM, 1980.

CABRAL, Diogo C. Águas passadas: sociedade e natureza no Rio de Janeiro oitocentista. In: Anais do XVI Encontro Nacional de Geógrafos, 2010, Porto Alegre. XVI Encontro Nacional de Geógrafos, 2010, p. 1-11.

CARDOSO, Adauto L. A cidade e seu estatuto: uma avaliação urbanística do Estatuto da Cidade. In: RIBEIRO, Luiz Cesar de Q. \& CARDOSO, Adauto L. (orgs.) Reforma urbana e gestão democrática: promessas e desafios do Estatuto da Cidade. Rio de Janeiro: Revan/FASE, 2003.

CARDOSO, Adauto L. e RIBEIRO, Luiz César de Q. Plano Diretor e gestão democrática da cidade. In: (orgs.) Reforma Urbana e gestão democrática: promessas e desafios do estatuto da cidade. Rio de Janeiro: Revan/FASE, 2003

CARLOS, Ana Fani A. A cidade. São Paulo: Contexto, 2003.

CARTER, Harold. La ciudad en el mundo en vias de desarollo. In:

Geografia Urbana. Instituto de Estúdios de Administración Local. P. 517-549.

El estúdio de la

CAVAlCANTI, Nireu Oliveira. A cidade de São Sebastião do Rio de Janeiro: as muralhas, sua gente, os construtores (1710-1810). Rio de Janeiro, UFRJ, 1997. Tese (Doutorado em História). Universidade Federal do Rio de Janeiro, 1997.

CAVALCANTI, Nireu. O Rio de Janeiro setecentista: a vida e a construção da cidade da invasão francesa até a chegada da corte. Rio de Janeiro: Jorge Zahar, 2004.

CHAUÍ, Marilena. Notas sobre utopia. Revista Ciência e Cultura. SBPC. Ano 60 - número especial 1 - julho de 2008.

COARACY, Vivaldo. Memórias da Cidade do Rio de Janeiro. Belo Horizonte: Itatiaia; São Paulo: EdUSP, 1988.

COARACY, Vivaldo. Memórias da cidade do Rio de Janeiro. Coleção Rio 4 Séculos, vol. 3. Rio de Janeiro: José Olympo, 1965. 
Código de ÁGUAS DECRETO No 24.643, DE 10 DE JULHO DE 1934. Rio de Janeiro. Arquivo Nacional, Impressos II -1. Leis e decretos.

CORONIL, Fernando. Natureza do pós-colonialismo: do eurocentrismo ao globocentrismo. In: A colonialidade do saber: eurocentrismo e ciências sociais. Perspectivas latinoamericanas. LANDER, Edgardo (org.) CLACSO: Buenos Aires, Argentina, 2005.

CORRÊA, Armando Magalhães. Terra carioca: fontes e chafarizes. Rio de Janeiro: Imprensa Nacional, 1939.

CORRÊA, Roberto Lobato. O espaço urbano. São Paulo: Ática, 1993.

COSTA, Alexander. Hidrogeografia e a Cidade do Rio de Janeiro. In: MARAFON, Glaucio e RIBEIRO, Marta F.(orgs.) Estudos de Geografia Fluminense. Rio de Janeiro: Livraria e Editora Infobook Ltda., 2002.

COSTA, Alexandre J. S. Tobias da. Hidrogeografia e a cidade do Rio de Janeiro. In: MARAFON, Gláucio José. RIBEIRO, Marta Foeppel (org.). Estudos de Geografia Fluminense. Rio de Janeiro: Livraria e Editora Infobook Ltds, 2002. P. 193-209.

COSTA, Lucia Maria Sá Antunes. Rios urbanos e o desenho da paisagem. In:

Rios e paisagens urbanas em cidades brasileiras. Rio de Janeiro: Viana\&Mosley: Ed. PROURB, 2006. P. 9-15

CUSTÓDIO, Vanderli. A relação cidade-água nos artigos dos Anais da Associação dos Geógrafos Brasileiros. Geousp, v. 20, p. 175-182, 2006.

CUSTÓDIO, Vanderli. Exemplos de Processos de Apropriação dos Recursos Hídricos do Alto Tietê. In: . A apropriação dos recursos hídricos e o abastecimento de água na Região Metropolitana de São Paulo. São Paulo: FFLCH/USP, 1994 (Dissertação de mestrado em Geografia Humana).

CUSTODIO, Vanderli. Processos socioespaciais urbanos no Brasil em uma perspectiva histórico-geográfica. Informativo da Associação dos Geógrafos Brasileiros - Seção local São Paulo. São Paulo, n. 94/95, $2^{\circ}$ semestre 2008. P. 18-21.

CUSTÓDIO V. O abastecimento de água: das bicas à Sabesp. In: Ana Maria de Almeida Camargo (coordenação). (Org.). São Paulo: metrópole em mosaico (Série Nossa História 3). São Paulo: Centro de Integração Empresa-Escola - CIEE, 2010, v. 3, p. 209-225

DELSON, Roberta Marx. Novas vilas para o Brasil-Colônia: planejamento espacial e social no século XVIII. Brasília: Edições Alva.

DERRUAU, Max. A cidade. In: Geografia Humana. vol. 2. São Paulo: Martins Fontes, 1973. P. 201-249.

FERNANDES, Nelson da Nóbrega. Capitalismo e morfologia urbana na longa duração: Rio de Janeiro (século XVIII-XXI). Scripta Nova. Revista Electrónica de Geografía y Ciencias Sociales. Barcelona: Universidad de Barcelona, 1 de agosto de 2008, vol. XII, núm. 270 (56). [http://www.ub.es/geocrit/sn/sn-270/sn-270-56.htm. Acesso em 23/01/2009]

FOUCAULT, Michel. Seguridad, territorio, población: Curso en el Collège de France: 1977-1978. Buenos Aires: Fundo de Cultura Económica, 2006.

FREYRE, Gilberto. Homens, terras e águas na formação agrária do Brasil: sugestões para um estudo de inter-relações. Boletim do Instituto Joaquim Nabuco de Pesquisas Sociais. Recife, v. 3, 1957, 10p. 
FRIDMAN, Fania. Donos do Rio em nome do Rei: uma história fundiária da cidade do Rio de Janeiro. Rio de Janeiro: Jorge Zahar Ed.: Garamond, 1999.

FRIDMAN, F.; MACEDO, V. A ordem religiosa no Rio de Janeiro. Revista Urbana, v. 1, p. 1-21, 2006.

KOWARICK, Lucio. A espoliação urbana. Rio de Janeiro: Paz e Terra, 1979.

LACOSTE, Yves. Geografia, isso serve, em primeiro lugar para fazer a guerra. São Paulo:Papirus, 1988.

LAGO, Luciana. O movimento de loteadores no Rio de Janeiro. Rio de Janeiro: IPPUR/UFRJ, 1990. (Dissertação de mestrado em Planejamento Urbano e Regional)

LAGO, Luciana C. do. Segregação sócio-espacial e condições urbanas de vida nos anos 80: a metrópole do Rio de Janeiro em questão. Caxambu: Anais do XI Encontro Nacional de Estudos populacionais da Associação Brasileira de Estudos Populacionais, 1998.

LAHUERTA, F. M. Geografias em movimento: Território e centralidade no Rio de Janeiro joanino (1808-1821). 2009. 151f. Dissertação (Mestrado) - Faculdade de Filosofia, Letras e Ciências Humanas, Universidade de São Paulo, 2009.

LAMEGO, Alberto R. O homem e a Guanabara. Rio de Janeiro: IBGE/CNG, 1964. 249p.

LEFEBVRE, Henri. O direito à cidade. São Paulo: Centauro, 2001.

LIMA, Ivaldo. Território e cidadania. Niterói: DG/IG, 2008 (mimeograf.)

LIMA, Ivaldo. Da representação do poder ao poder de representação: uma perspectiva geográfica. In: SANTOS, Milton ... [et ali]. Território, territórios: ensaios sobre o ordenamento territorial. RJ: DP\&A, 2006.

MACEDO, Valter Luiz de. O passado de volta: planejamento estratégico, mercantilização do espaço público e desigualdade urbana. Rio de Janeiro: UFRJ, 2002. Dissertação (Mestrado em Planejamento Urbano e Regional) - Instituto de Pesquisa e Planejamento Urbano e Regional, Universidade Federal do Rio de Janeiro, Rio de Janeiro, 2002.

MAGALHÃES CORRÊA, Armando. Terra carioca: fontes e chafarizes. Rio de Janeiro: Imprensa Nacional, 1939.

MARICATO, E. Autoconstrução, a arquitetura possível. In: MARICATO, Ermínia. A Produção capitalista da casa (e da cidade) no Brasil industrial. São Paulo: Editora AlfaOmega, 1979, p. 71-93.

MARINS, P. C. G. Através da rótula - sociedade e arquitetura no Brasil, séculos XVII a XX. São Paulo: Humanitas / FFLCH / USP, 2001. 320 p

MARQUES, Eduardo L. Desigualdades sociais e infra-estrutura urbana: a produção dos equipamentos de saneamento no Rio de Janeiro. Rio de Janeiro: IPPUR/UFRJ, 1993. (Dissertação em Mestrado ). .

MARTINS, Luciana L. ABREU, Mauricio A. Paradoxos da modernidade: o Rio de Janeiro do período joanino, 1808-1821. In: FERNANDES, Edesio. VALENÇA, Márcio Moraes (org.). Brasil Urbano. Rio de Janeiro: Mauad, 2004. P. 211-236.

"Memória apresentada pelo engenheiro João Manuel da Silva sobre o regime das águas da cidade do Rio de Janeiro e Melhoramentos necessários ao escoamento das mesmas e bem assim obras públicas julgadas úteis." Rio de Janeiro. Arquivo Geral da Cidade do Rio de Janeiro, 4/9/1811. Manuscrito 1-34, 26,37. Códice 39-1-36. 
MIZUBUTI, Satie. Uma releitura do movimento associativo de bairro. In: SANTOS, Milton [et ali]. Território, territórios: ensaios sobre o ordenamento territorial. RJ: DP\&A, 2006.

MIZUBUTI, Satie. O movimento associativo de bairro em Niterói. São Paulo: FFLCH/USP, 1986. (Tese de doutorado em Geografia Humana).

MORAES, Antonio C. Robert. Meio ambiente e ciências humanas. São Paulo: Hucitec, 1997

MORAES, R. Neoliberalismo: De onde vem para onde vai? São Paulo: Editora Senac, 2001

MOREIRA, Ruy. Pensar e Ser em Geografia - ensaios de história, epistemologia e ontologia do espaço geográfico. São Paulo: Contexto, 2007.

MOREIRA, R. Espaço: corpo do tempo - construção geográfica da sociedade. 1994. $243 \mathrm{f}$. Tese (Doutorado) - Faculdade de Filosofia Letras e Ciências Humanas, Universidade de São Paulo, São Paulo, 1994.

MOREIRA, Ruy. A geografia serve para desvendar máscaras sociais. In: MOREIRA, Ruy (org.) Geografia: Teoria e crítica - o saber posto em questão. Petrópolis: Vozes 1982.

MUMFORD, Lewis. A cidade na história: suas origens, transformações e perspectivas. São Paulo:Martins Fontes, 1998.

NASCIMENTO, D.R.; SILVA, M. A. D. da. As fontes em tempos de D. João: abastecimento de água e escoamento de esgoto no Rio de Janeiro oitocentista In: Revista do Arquivo Geral da Cidade do Rio de Janeiro - 200 anos da chegada da Família Real, v. 2, p. 58-73, 2008.

NOBREGA, Claudia. São Sebastião do Rio de Janeiro: a construção de uma cidadecapital no Brasil colonial. Rio de Janeiro: UFRJ, 2003. Tese (Doutorado em Planejamento Urbano e Regional) - Instituto de Pesquisa e Planejamento Urbano e Regional, Universidade Federal do Rio de Janeiro, Rio de Janeiro, 2003.

NORONHA SANTOS, Francisco Agenor. Aqueduto da Carioca. Revista do Serviço de Patrimônio Histórico e Artístico Nacional 4, 1940

NORONHA SANTOS, Francisco Agenor. As freguesias do Rio Antigo. Rio de Janeiro: O Cruzeiro, 1965.

NUNES, Carlos Gustavo. Largo da Carioca: 1608-1999 um passeio no tempo. Rio de Janeiro: Novas Direções, 1999.

OLIVEIRA, Rogério Ribeiro de. Terras cançadas e mattas estragadas: uma pequena história ambiental das chuvas e florestas do Rio de Janeiro. In: TANGARI, Vera Regina... [ET AL.] Águas Urbanas: uma contribuição para a regeneração ambiental como campo disciplinar integrado. Rio de Janeiro: UFRJ, Faculdade de Arquitetura e Urbanismo, 2007. P. 285-295

PERLMAN, Janice E. O mito da marginalidade - Favelas e política no Rio de Janeiro. Rio de Janeiro: Paz e Terra, 2002.

PETRELLA, Ricardo. A água. O desafio do bem comum. In: NEUTZLING, Inácio (org.) Água: bem público universal. São Leopoldo - RS: Unisinos, 2004.

PORTO-GONÇALVES, Carlos Walter. A globalização da natureza e a natureza da globalização. Rio de Janeiro: Civilização Brasileira, 2006. 
PORTO-GONÇALVES, Carlos Walter. Da Geografia às Geo-grafias: um mundo em busca de novas territorialidades. In: CECENA, Ana E. e SADER, Emir. (org.). La guerra infinita: hegemonía y terror mundial. Buenos Aires: Clacso, 2002.

PORTO-GONÇALVES, Carlos Walter. EI desafio ambiental. México, D.F.: Pnuma, 2007.

PORTO-GONÇALVES, Carlos Walter. Geo-grafias: movimientos sociales, nuevas territorialidades y sustentabilidad. México, D.F: Siglo XXI, 2001.

PRETECEILLE, Edmond e VALLADARES Licia do P. A desigualdade entre os pobres favela, favelas. In: HENRIQUES, R. (org.) Desigualdade e Pobreza no Brasil. Rio de Janeiro: IPEA, 1999.

PRIETO, Gustavo F. T. Casos de descaso: Estado, políticas habitacionais e abastecimento de água na Zona Oeste da cidade do Rio de Janeiro. São Paulo: Anais do XV Encontro Nacional de Geógrafos, 2008.

QUIJANO, Anibal. Colonialidade do poder, eurocentrismo e América Latina. In: LANDER, Edgardo (org.) A colonialidade do saber: eurocentrismo e ciências sociais. Perspectivas latino-americanas. Buenos Aires, Argentina: CLACSO, 2005.

REIS FILHO, Nestor Goulart. Contribuição ao estudo da evolução urbana do Brasil. São Paulo: Editora da Universidade de São Paulo, 1968.

REIS FILHO, Nestor Goulart. Notas sobre a evolução dos estudos de historia da urbanização e do urbanismo no Brasil. Cadernos de pesquisa do LAP. São Paulo, n. 29, jan/jun 1999.

REIS FILHO, Nestor Goulart. Notas sobre o urbanismo no Brasil: Primeira parte: período colonial. Cadernos de pesquisa do LAP. São Paulo, n. 8, jul/ago 1995.

REPRESENTAÇÃO de Paulo Fernandes Viana a S.A.R., tratando do abastecimento d'água e das edificações na cidade do Rio de Janeiro. Rio de Janeiro, s.d. Biblioteca Nacional. Manuscritos, II 34-32- 31.

REZENDE, S. C.; HELLER, L. . O saneamento no Brasil: políticas e interfaces. 2. ed. Belo Horizonte: Editora UFMG, 2008. 387 p

RIBEIRO, Ana Clara Torres. Cidades, reivindicações e equipamentos coletivos. In: RIBEIRO, Ana Clara Torres, TAVARES, H.M \& PIQUET, R. O desenvolvimento urbano em questão - textos didáticos. Rio de Janeiro: PUBLIPUR/PUR, 1986.

ROCHA, Amara. A sedução da luz: o imaginário da eletrificação no Rio de Janeiro (1892-1914) Rio de Janeiro: IFCS/UFRJ, 1996. (Dissertação de Mestrado em História Social).

RODRIGUES, Arlete Moysés. A cidade como direito. Scripta Nova. Revista Electrónica de Geografía y Ciencias Sociales. Barcelona: Universidad de Barcelona, 1 de agosto de 2007, vol. XI, núm. 245 (33). [http://www.ub.es/geocrit!sn/sn-24533.htm. Acesso em 22/01/2009]

ROSSA, Walter. A urbe e o traço. Uma década de estudos sobre o urbanismo português. Lisboa: Almedina 2002.

SADER, Eder. Quando novos personagens entram em cena. São Paulo: Paz e Terra, 1988.

SALGADO, Ivone. A modernização da cidade setecentista: o contributo das culturas urbanísticas francesa e inglesa. In: TEIXEIRA, Manuel C. (org.). A construção da cidade brasileira. Lisboa: Livros Horizonte, 2004. P. 333-351.

SAMPAYO, M. G. T. O modelo urbanístico de tradição islâmica nas cidades portuguesas (sec. VIII - XIII). 2001. Dissertação (Mestrado) - Escola de Tecnologias e Arquitectura, Instituto Superior das Ciências do Trabalho e da Empresa, Lisboa, 2001. 
SANTOS, Milton. 1992: a redescoberta da natureza. São Paulo: Humanitas/FFLCH-USP, 1998.

SANTOS, Milton. O espaço do cidadão. São Paulo: EdUSP, 2007.

SANTOS, Milton. A Natureza do Espaço: Técnica e Tempo, Razão e Emoção. $4^{\mathrm{a}}$ Ed. São Paulo: Edusp, 2008.

SANTOS, Milton.. A urbanização brasileira. São Paulo: Hucitec, 1993.

SILVA, Rosauro Mariano da. Do poço do Cara de Cão à adutora do Guandu. Revista de Engenharia do Estado da Guanabara, jan/mar 1965.

TERRA, Carlos. Canal do mangue: estruturação urbana, paisagística e "ambiental" no Rio de Janeiro do século XIX. In: TANGARI, Vera Regina... [ET AL.] Águas Urbanas: uma contribuição para a regeneração ambiental como campo disciplinar integrado. Rio de Janeiro: UFRJ, Faculdade de Arquitetura e Urbanismo, 2007. P. 277-284

VALLADARES, Licia. Passa-se uma casa: análise do Programa de Remoção de Favelas do Rio de Janeiro. Rio de Janeiro: Zahar, 1980.

VASCONCELOS, Pedro de Almeida. Les agents de la formation des Villes coloniales bresiliennes. In: DIAS, Leila Christina. RAUD, Cécile. Villes et régions au Brésil. Paris: L'Harmattan, 2000. P. 79-92 